Florida International University FIU Digital Commons

FIU Electronic Theses and Dissertations

University Graduate School

$1-20-2005$

\title{
Effect of scaling on hydraulic conductivity in a Karst Aquifer
}

Vincent J. DiFrenna

Florida International University

DOI: $10.25148 /$ etd.FI14062291

Follow this and additional works at: https://digitalcommons.fiu.edu/etd

Part of the Geology Commons

\section{Recommended Citation}

DiFrenna, Vincent J., "Effect of scaling on hydraulic conductivity in a Karst Aquifer" (2005). FIU Electronic Theses and Dissertations. 2819.

https://digitalcommons.fiu.edu/etd/2819

This work is brought to you for free and open access by the University Graduate School at FIU Digital Commons. It has been accepted for inclusion in FIU Electronic Theses and Dissertations by an authorized administrator of FIU Digital Commons. For more information, please contact dcc@fiu.edu. 
Miami, Florida

\section{EFFECT OF SCALING ON HYDRAULIC CONDUCTIVITY IN A KARST AQUIFER}

A thesis submitted in partial fulfillment of the requirements for the degree of

MASTER OF SCIENCE

in

GEOSCIENCES

by

Vincent J. DiFrenna

2005 
To: Interim Dean Mark Szuchman

College of Arts and Sciences

This thesis, written by Vincent J. DiFrenna, and entitled Effect of Scaling on Hydraulic Conductivity in a Karst Aquifer, having been approved in respect to style and intellectual content, is referred to you for judgment.

We have read this thesis and recommend that it be approved.

Michael Gross

Michael Sukop

M. R. Savabi

Rene M. Price, Major Professor

Date of Defense: January 20, 2005

The thesis of Vincent J. DiFrenna is approved.

Interim Dean Mark Szuchman

College of Arts and Sciences

Dean Douglas Wartzok University Graduate School

Florida International University, 2005 


\section{DEDICATION}

This Masters Degree is for three people; my daughter Hannah for always being ready to play with me, my daughter Camila for always smiling when I get home, and my wife Carolina for running our home without me so I could study. Without the three of you I would have neither started nor finished.

Thank You 


\section{ACKNOWLEDGMENTS}

I would like to thank all of my committee members for their interest in me. Their comments continually made me increasingly fascinated with my studies. I would especially like to thank Dr. René M. Price for her help in editing and correcting my thesis and Dr. Reza Savabi, who provided the financial support that made this project possible. The design and construction of the various pieces of equipment built for this study were only possible because of the expert advice given to me by Adrian Villaraos. I would also like to thank all the graduate students in the Earth Science department, at one time or another every one has helped me with something I needed. Lastly I would like to thank Diane Pirie who found all the pieces of equipment I needed to keep working. 


\section{ABSTRACT OF THE THESIS \\ EFFECT OF SCALING ON HYDRAULIC CONDUCTIVITY}

IN A KARST AQUIFER

by

Vincent J. DiFrenna

Florida International University, 2005

Miami, Florida

Professor Rene M. Price, Major Professor

Hydraulic conductivity was determined for samples from the Biscayne Aquifer in Miami Florida at bench and field scales. Hydraulic conductivity values obtained were examined for increase due to scale and for anisotropy. Bench scale testing was performed on Key Largo Limestone cubes for total porosity, effective porosity, and hydraulic conductivity. Total porosity was determined by drying and weighing, while effective porosity was determined by submersion. Hydraulic conductivity was determined in a permeameter for each axis of each cube. Field scale testing of hydraulic conductivity was performed with slug tests in the Miami Oolite Formation at the Homestead General Airport. Aquifer scale values for hydraulic conductivity were taken from the literature. Hydraulic conductivity was found to increase with scale in the Biscayne Aquifer. Furthermore, it increased greatly above an effective porosity of 33 percent. Anisotropy was found to vary in cubes with depth and in proximity to a dense laminated layer. 


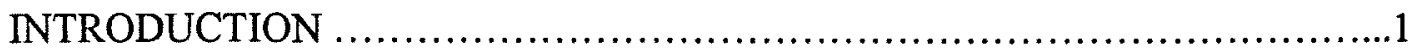

1.1 Importance...............................................................

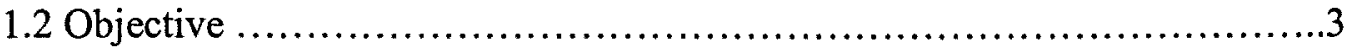

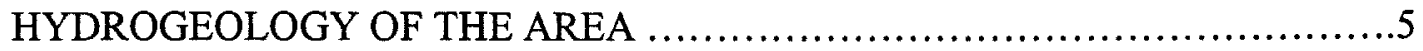

2.1 Biscayne Aquifer ......................................................

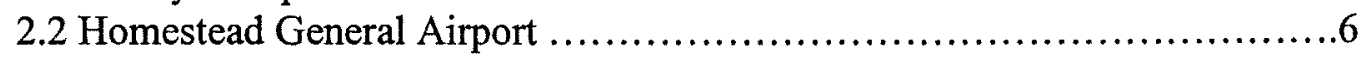

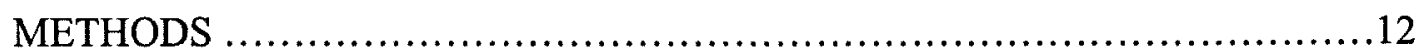

3.1 Scale Tested and Technique Used .....................................12

3.2 Cube Testing ...........................................................12

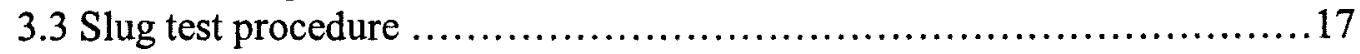

3.4 Statistical Analysis................................................ 19

RESULTS................................................................... 30

4.1 Cubes of Key Largo Limestone ..................................... 30

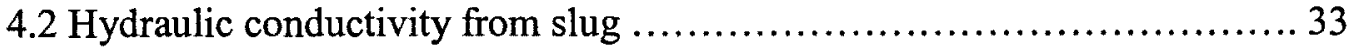

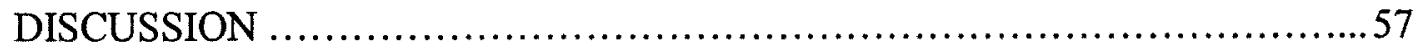

5.1 Total Porosity, Effective Porosity ...................................5 57

5.2 Hydraulic conductivity ..................................................61

5.3 Effect of Scaling on Hydraulic Conductivity ............................65

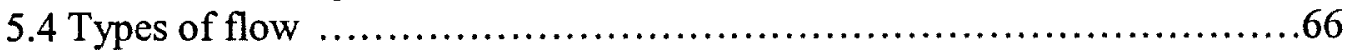

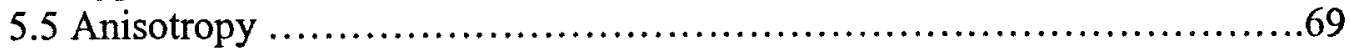

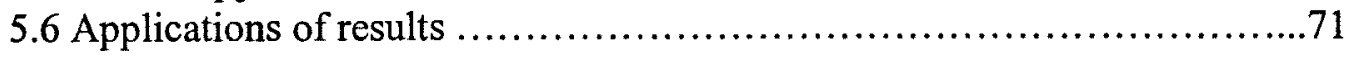

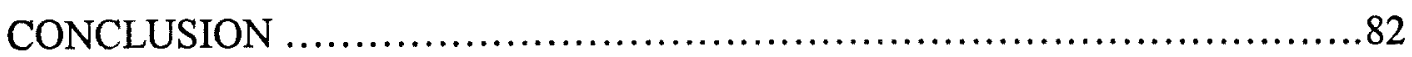

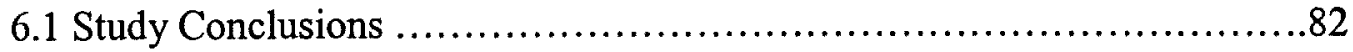

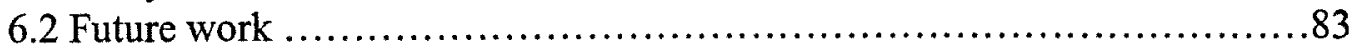

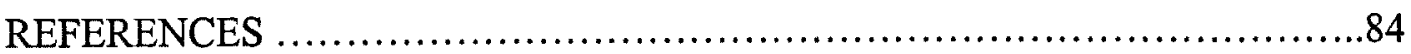

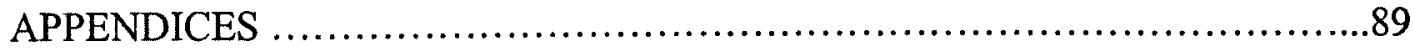




\section{LIST OF TABLES}

TABLE

PAGE

Table 3.1 Head level changes, in $\mathrm{cm}$, caused by immersing each slug into a $5.08 \mathrm{~cm}$ PVC well.

Table 4.1 Bulk density, total porosity, and effective porosity values for 8,000 $\mathrm{cm}^{3}$ Key Largo Limestone Cubes.

Table 4.2 Bulk density, total porosity, and effective porosity for $27,000 \mathrm{~cm}^{3}$

Key Largo Limestone Cubes. 34

Table 4.3 Data used to plot figure 4.3 from $20 \mathrm{~cm} \mathrm{ks} \mathrm{\# 1} \mathrm{h1} \mathrm{axis.}$ 35

Table 4.4 Hydraulic conductivity values for all axes of all $20 \mathrm{~cm}$ Key Largo Limestone Cubes. 35

Table 4.5 Statistics for table 4.4; figure 4.4. 36

Table 4.6 Average hydraulic conductivity values of each $20 \mathrm{~cm}$ Key Largo Limestone Cube. 36

Table 4.7 Statistics for table 4.6; figure 4.6. 36

Table 4.8 Hydraulic conductivity values for all axes of all $30 \mathrm{~cm}$ Key Largo Limestone Cubes.

Table 4.9 Statistics for table 4.8; figure 4.8.

Table 4.10 Average hydraulic conductivity values of each $30 \mathrm{~cm}$ Key Largo Limestone Cube. 38

Table 4.11 Statistics for table 4.10; figure 4.10 38

Table 4.12 Table showing hydraulic conductivity values for each well with each size slug. 38

Table 4.13 Statistics for table 4.12; figure 4.15. .39

Table 4.14 Max., Min., Mean, and Standard Deviation for hydraulic conductivity $(\mathrm{m} /$ day) each slug size.

Table 4.15 Statistics for table; 4.14 figure 4.16. 39 
Table 5.1 Comparison of total porosity on core plugs and whole core samples .......73

Table $5.2 \quad$ Comparison of hydraulic conductivity. ................................................. 74 


\section{LIST OF FIGURES}

FIGURE

PAGE

Figure 2.1 Diagram showing location and extent of the Biscayne Aquifer (Adapted from Miller, 1990)

Figure 2.2 Generalized hydrogeologic framework of aquifer systems in Dade County (Adapted from Fish and Stewart, 1991)..................8

Figure 2.3 Transect map of Dade County .............................................................. 9

Figure 2.4 Hydrogeologic units along a South to North transect (I-I') ................... 10

Figure 2.5 Air photo of Homestead General Airport shown at $4 \mathrm{~m}$ resolution. The location of the Homestead General Airport in Dade County is shown in Figure 2.3. Transect line of approximately $2 \mathrm{~km}$ indicated as bold black line; well clusters indicated as open circles. ....... 11

Figure 3.1 Key Largo Limestone block cut to make $20 \mathrm{~cm}$ and $30 \mathrm{~cm}$ cubes.......... 22

Figure 3.2 Adjacent columns of $30 \mathrm{~cm}$ Key Largo Limestone cubes ....................... 23

Figure 3.3 Photo of cubes and their relative positions ............................................... 24

Figure 3.4 Apparatus used for testing effective porosity ........................................ 25

Figure 3.5 Vacuum pressure regulator used to maintain constant pressure............... 26

Figure 3.6 Permeameter used on $20 \mathrm{~cm}$ and $30 \mathrm{~cm}$ Key Largo Limestone cubes, ... 27

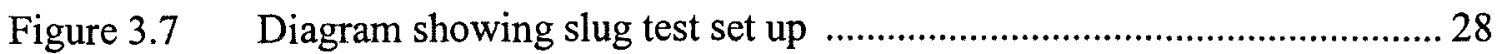

Figure 3.8 Example of matched curve from Butler spread sheet used...................... 29

Figure 4.1 Relationship of total porosity to effective porosity for both $20 \mathrm{~cm}$ and $30 \mathrm{~cm}$ Key Largo Limestone cubes 40

Figure 4.2 Example of best fit line used to determine hydraulic conductivity 41

Figure 4.3 Hydraulic conductivity (m/day) for each axis of each $20 \mathrm{~cm}$ Key Largo Limestone cube

Figure 4.4 Diagram shows box and whisker plots of the average hydraulic conductivity value of each $20 \mathrm{~cm}$ Key Largo Limestone cube. 
Figure 4.5 Diagram shows modified box and whisker plots of the average hydraulic conductivity value of each axis of the $20 \mathrm{~cm}$ Key Largo Limestone cubes.

Figure 4.6 Hydraulic conductivity ellipses of all

$20 \mathrm{~cm}$ Key Largo Limestone cubes .

Figure 4.7 Hydraulic conductivity ( $\mathrm{m} /$ day) for each axis of each $30 \mathrm{~cm}$ Key Largo Limestone cube

Figure 4.8 Diagram shows box and whisker plots of the average hydraulic conductivity value of each $30 \mathrm{~cm}$ Key Largo Limestone cube

Figure 4.9 Diagram shows modified box and whisker plots of the average hydraulic conductivity value of each axis of the $30 \mathrm{~cm}$ Key Largo Limestone cubes

Figure 4.10 Hydraulic conductivity ellipses of all $30 \mathrm{~cm}$ Key Largo Limestone cubes

Figure 4.11 Hydraulic conductivity high head test without high head points .............50

Figure 4.12 Hydraulic conductivity high head test with high head points .................50

Figure 4.13 Effective porosity with hydraulic conductivity of cubes ..........................51

Figure 4.14 Head level and pore size combinations and the resulting Reynolds numbers for $20 \mathrm{~cm}$ cubes

Figure 4.15 Head level and pore size combinations and the resulting Reynolds numbers for $30 \mathrm{~cm}$ cubes

Figure 4.16 Range of validity of Darcy's law 54

Figure 4.17 Daigram shows differences amongst average hydraulic conductivity values for each well cluster

Figure 4.18 Diagram shows comparison of hydraulic conductivity generated by 30,45 , and $60 \mathrm{~cm}$ slugs .56

Figure 5.1 Box plot showing porosity values for core plugs and whole plugs. Dark lines indicate mean values, circles indicate outliers (Adapted from Cunningham, 2004). 
Figure 5.2 Comparison of total porosity of $20 \mathrm{~cm}$ and $30 \mathrm{~cm}$

Key Largo Limestone cubes

Figure 5.3 Comparison of effective porosity of $20 \mathrm{~cm}$ and $30 \mathrm{~cm}$ Key Largo

Limestone cubes

Figure 5.4 Box plot of hydraulic conductivity at increasing scales for the Biscayne Aquifer. Mean values of hydraulic conductivity are shown as bold lines. Outliers are shown as circles. 77

Figure 5.5 Average hydraulic conductivity of each $20 \mathrm{~cm}$ and $30 \mathrm{~cm}$ cube 78

Figure 5.6 Hydraulic conductivity of each axis (v: vertical; $h 1$ and $h 2$ : horizontal) .79

Figure 5.7 Diagram shows hydraulic conductivity values from the Lucayan Aquifer 80

Figure 5.8 Scale effect on the hydraulic conductivity in fractured and karstified limesone aquifers 


\section{CHAPTER 1}

\section{INTRODUCTION}

\subsection{Importance}

Karst terrains cover $7-12 \%$ of the continental surface throughout the earth (Ford and Williams, 1989; Drew, 1999). An estimated $25 \%$ of the world's population is supplied with water largely or entirely from karst aquifers (Ford and Williams, 1989; PulidoBosch, 1999). In Miami the karst aquifer of interest is the Biscayne Aquifer. In 1979 it was declared a sole source aquifer for Miami Dade County (Federal Register Notice, 1979). Ground water modeling is required in order to reduce uncertainties and to provide information for the proper management and protection of this aquifer.

An important parameter in the construction and application of ground water models is hydraulic conductivity. Karst aquifers can vary greatly in their hydrologic properties as a function of scale, including hydraulic conductivity (Whitaker and Smart, 2000).

This change in hydraulic conductivity is proven to be dependent on the scale, and independent of the method of testing (Schulze-Makuch and Cherkauer, 1998). The scale of the event being modeled determines the hydraulic conductivity value for the model. A hazardous spill, that is small in scale, requires a localized hydraulic conductivity value. In comparison water extraction for municipal water supply, that is large in scale, requires a hydraulic conductivity value that is applicable to the entire aquifer.

Water is a limited resource in south Florida. In Miami-Dade County the Biscayne Aquifer supplies water needs of the 2.2 million inhabitants and farming interests (MiamiDade County Quickfacts Website http://quickfacts.census.gov/qfd/states/12/12086.html). High vertical infiltration rates permit rapid infiltration of the 140 to 160 average $\mathrm{cm}$ of 
rain per year that are the primary recharge for the Biscayne Aquifer (Leach et al., 1972;

Klein and Hull, 1978). Roughly $70 \%$ of this volume of rain falls during the rainy season from June to October (Leach et al, 1972). Proper management is required to insure there is an adequate supply of water during the entire year.

The Everglades serve as a reservoir for the Biscayne Aquifer. The water needs of the natural systems, Florida residents, and agricultural interests currently exceed the water supply available. Concerns over competing water demands are attempting to be relieved through the Comprehensive Everglades Restoration Plan (CERP). CERP is a framework and guide to restore, protect, and preserve the water resources of central and southern Florida, including the Everglades. It was designed to capture, store and redistribute fresh water previously lost to tide and to regulate the quality, quantity, timing and distribution of water flows (CERP website http://www.evergladesplan.org/about/rest_plan.cfm).

A hydraulic connection exists between the Biscayne Aquifer and the surface waters of the Everglades. Any water level changes planned for the Everglades as part of CERP will affect the water level of the Biscayne Aquifer. Conversely, any water removed from the Biscayne Aquifer will affect the surface waters of the Everglades.

Other areas of concern for the Biscayne Aquifer include saltwater intrusion and the introduction of pollutants. Models are required to balance the volume of ground water extracted against the increased saltwater intrusion that the extraction causes. Sources of pollutants include industrial and hydrocarbon wastes; sinking polluted surface streams; sinkhole dumps; agriculturally derived nitrates, herbicide and pesticide residues; highway spills; leaking sewer lines, pipelines, and storage tanks. Almost any imaginable source of 
pollution can be transmitted rapidly to the subsurface and into the ground water system of a karst aquifer (White, 1989; Kacaroglu, 1999).

Groundwater flow in a karst aquifer moves in two different modes, matrix or conduit. Scale may decide which type of flow is occurring. Matrix flow moves through intergranular (primary) pores, and is characterized by Darcian flow (Sasowsky and Wicks 2000) according to the following equation:

$\mathrm{Q}=-\mathrm{KAdh} / \mathrm{dl}$;

where $Q$ refers to flow rate. The negative sign (-) indicates that flow is in the direction of higher head to lower head, $K$ refers to hydraulic conductivity, $A$ refers to cross-sectional area perpendicular to the flow direction, and $d h / d l$ refers to change in head divided by change in length. Alternatively conduit flow occurs in enlarged fractures, and may be turbulent and non-Darcian (Sasowsky and Wicks, 2000). Anisotropy within an aquifer can result in nonradial flow along preferential zones, which can result in inaccurate estimates of flow paths and travel times (Knochenmus and Robinson, 1996). An inaccurate estimate of flow paths and travel times could lead to inaccurately determining the capture zone of a well field, which could allow part of the capture zone of the well field to be unprotected.

\subsection{Objective}

The objective of this study was to determine values of hydraulic conductivity across increasing scales in the Biscayne Aquifer. Bench scales used were $20 \mathrm{~cm}$ and $30 \mathrm{~cm}$ limestone cubes. Field scales used were $5.08 \mathrm{~cm}$ diameter wells with $1.5 \mathrm{~m}$ of screen length, and pump test values from the literature. The limestone cubes were also tested for 
total porosity, effective porosity and anisotropy. Comparing hydraulic conductivity values of the three mutually perpendicular axes within the Key Largo Limestone cubes for differences determined if anisotropy existed amongst axes. Values of hydraulic conductivity and porosity obtained in this study will assist in modeling ground water flow at different scales within the Biscayne aquifer, and may be applied in other surficial karst aquifers with similar properties. 


\section{CHAPTER 2}

\section{HYDROGEOLOGY OF THE AREA}

\subsection{Biscayne Aquifer}

The Biscayne Aquifer was declared a sole source aquifer for Miami Dade County in 1979 (Federal Register Notice, 1979). It is an unconfined, dominantly karst aquifer system that extends from Palm Beach County in the north, across Dade County, and slightly into Monroe county at its south western edge (Figure 2.1). The Biscayne Aquifer is shaped like a wedge with the narrow edge pinching out to the west of Dade County 56 to 64 kilometers inland and thickening to approximately $73 \mathrm{~m}$ in depth along the Atlantic shoreline (Klein and Hull, 1978) (Figure 2.2). Major geologic formations of the Biscayne Aquifer include the Pamlico Sand, the Miami Oolite Formation, the Anastasia Formation, the Key Largo Limestone Formation, and the Fort Thompson Formation, all of which were formed in the Pleistocene age. Additionally, the upper 13 meters of the underlying Tamiami Formation, which was formed in the Miocene age, may also be included in the Biscayne Aquifer if it has a high hydraulic conductivity (Fish and Stewart, 1991). The Hawthorn Group, a 167-243 meter thick aquitard consisting of green clay, silt, limestone, and fine sand, underlies these formations. The Fort Thompson Formation underlies the Miami Oolite Formation throughout Dade County except in the northwestern corner of Dade County where it is exposed at the surface (Fish and Stewart, 1991). North of the Tamiami Trail the Miami Oolite Formation is overlain by the Pamlico Sand Formation. Interfingered with these formations are the Anastasia Formation to the north and the Key

Largo Limestone Formation to the south (Fish and Stewart, 1991). The Key Largo Limestone Formation is a porous, crystalline, coralline limestone. The Fort Thompson 
Formation is a series of marine, brackish-water, and freshwater limestones ranging from slightly porous to very porous. It can have a hydraulic conductivity of up to 12,000 m/day (Fish and Stewart, 1991; Genereux and Guardiario, 1998). The Miami Oolite Formation is composed of oolitic spheres cemented together that have acquired secondary porosity. Together these formations can give the Biscayne aquifer a hydraulic conductivity up to $3,000 \mathrm{~m} /$ day and a transmissivity of $92,000 \mathrm{~m}^{2} /$ day in the area around Krome Avenue in Homestead. In central and southeastern Dade County transmissivity may exceed $92,000 \mathrm{~m}^{2} /$ day. In extreme cases transmissivity near Homestead may exceed $185,000 \mathrm{~m}^{2} /$ day. The high transmissivities are associated with thick sections of the Fort Thompson Formation (Fish and Stewart, 1991).

\subsection{Homestead General Airport}

The Homestead General Airport is located in southern Dade County and is separated from Everglades National Park by a canal (Figure 2.3, and Figure 2.4). The area of the airport not used for flight operations is used for commercial farming. Farming has tilled the field flat with the exception of a trench that was dug for fill to construct the runway. There are four clusters of wells running from east to west across the field, making a transect roughly $2 \mathrm{~km}$ long (Figure 2.5 ). The clusters are named, from east to west, East, Mid-field, Glider, and Orchard. Slug tests were performed on three wells from the East cluster, one well from the Mid-field cluster, three wells from the Glider cluster, and two wells from the Orchard cluster. Wells used in this study were previously installed by the USDA. Well construction details obtained from the driller indicated that the well depths ranged from 5.2 meters to 6.1 meters. These depths were confirmed by measurements. 
Each of these wells used $5.08 \mathrm{~cm}$ schedule 40 PVC pipe that was screened in the lower

1.5 meters with 0.030 factory slot screening. Clean silica sand was used to fill the annulus around the well screen. A combination of \#16 to \#10 sieve size (0.99 to $1.6 \mathrm{~mm})$ diameter sand was used. All wells used for slug testing were screened in the Miami Oolite Formation.

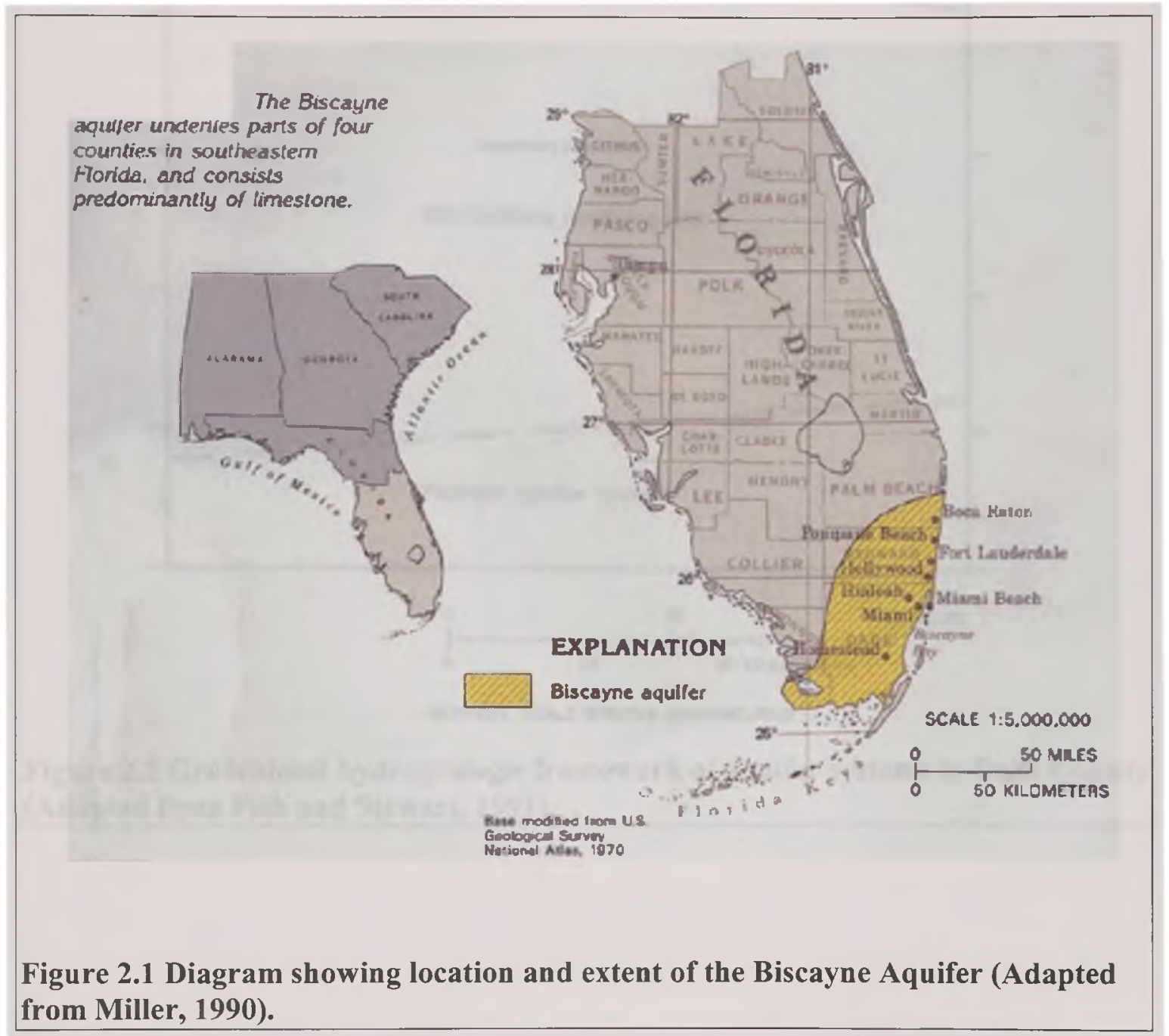




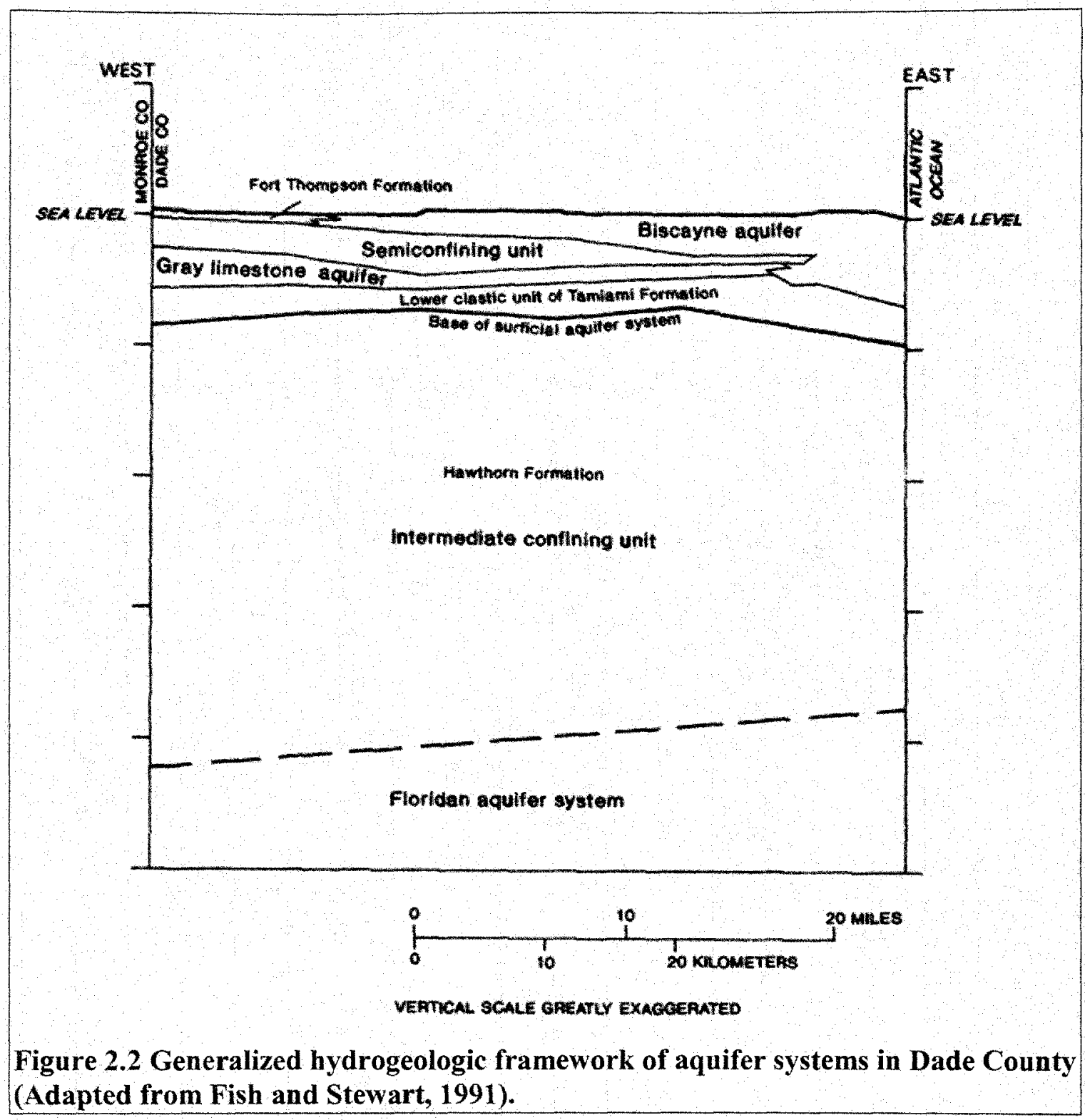




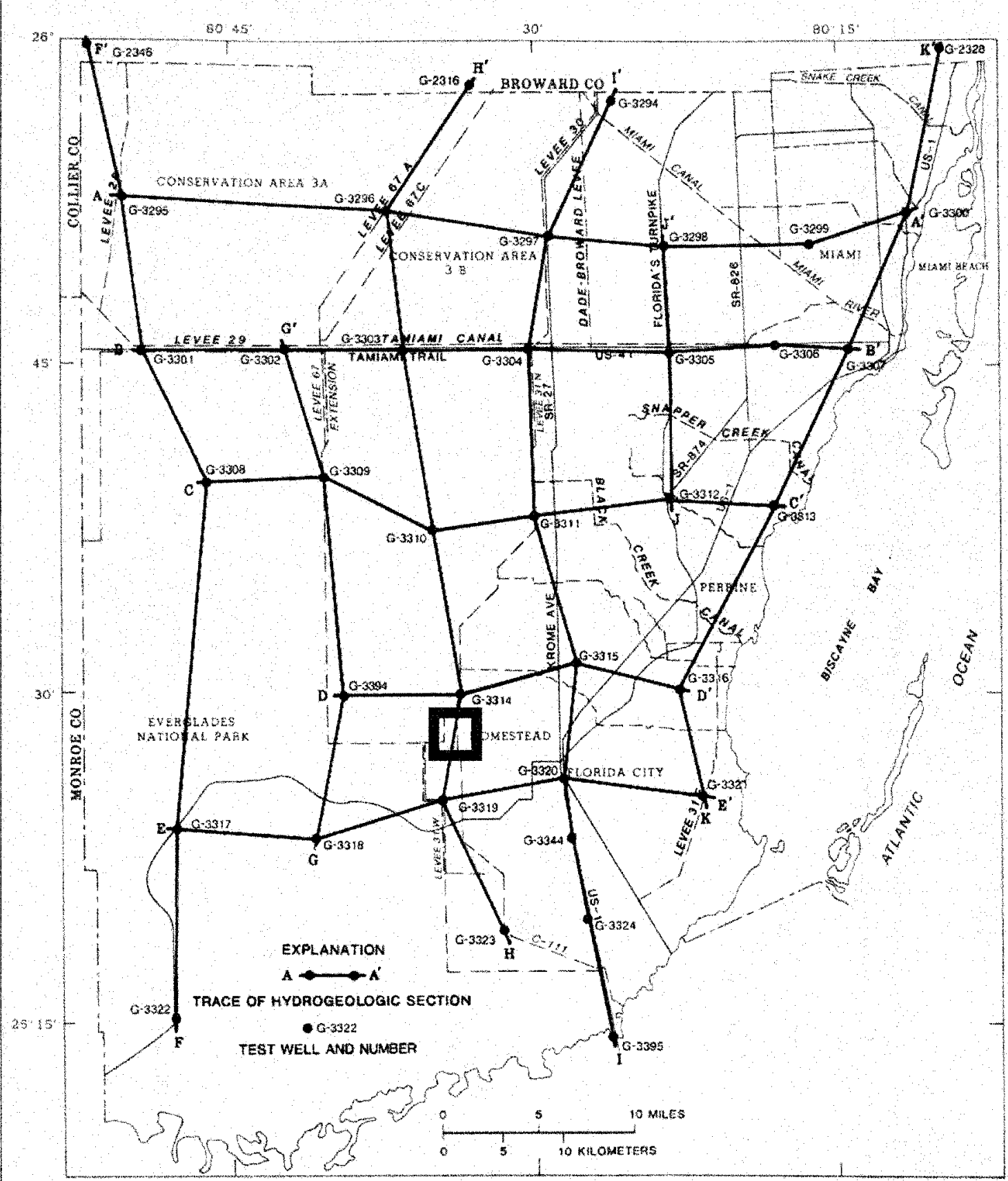

Figure 2.3 Transect map of Dade County showing I-I' transect in Figure 2.4 (Adapted from Fish and Stewart, 1991). This transect passes within $5 \mathrm{~km}$ to the Homestead General Airport shown within the bold square. 


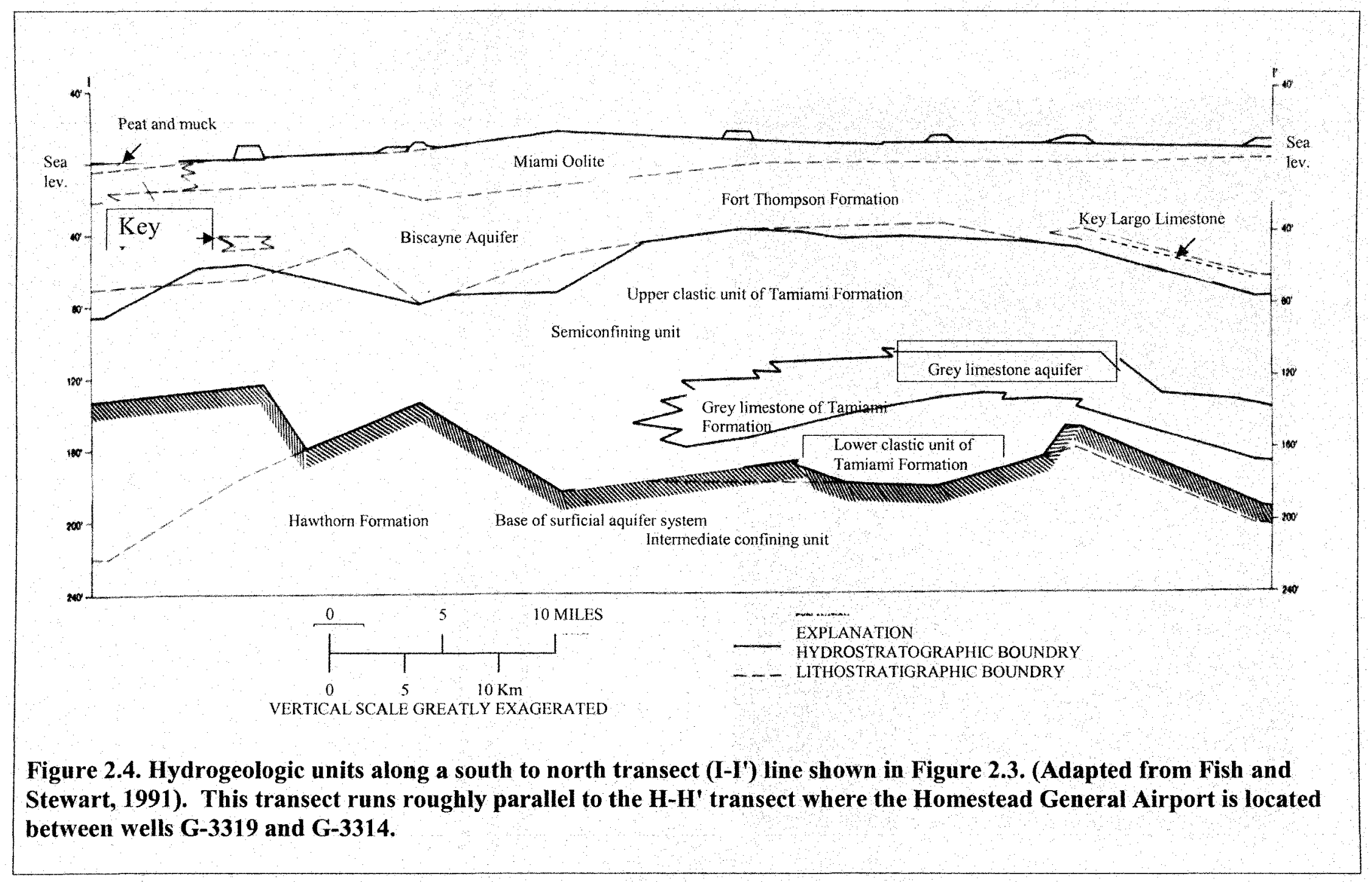




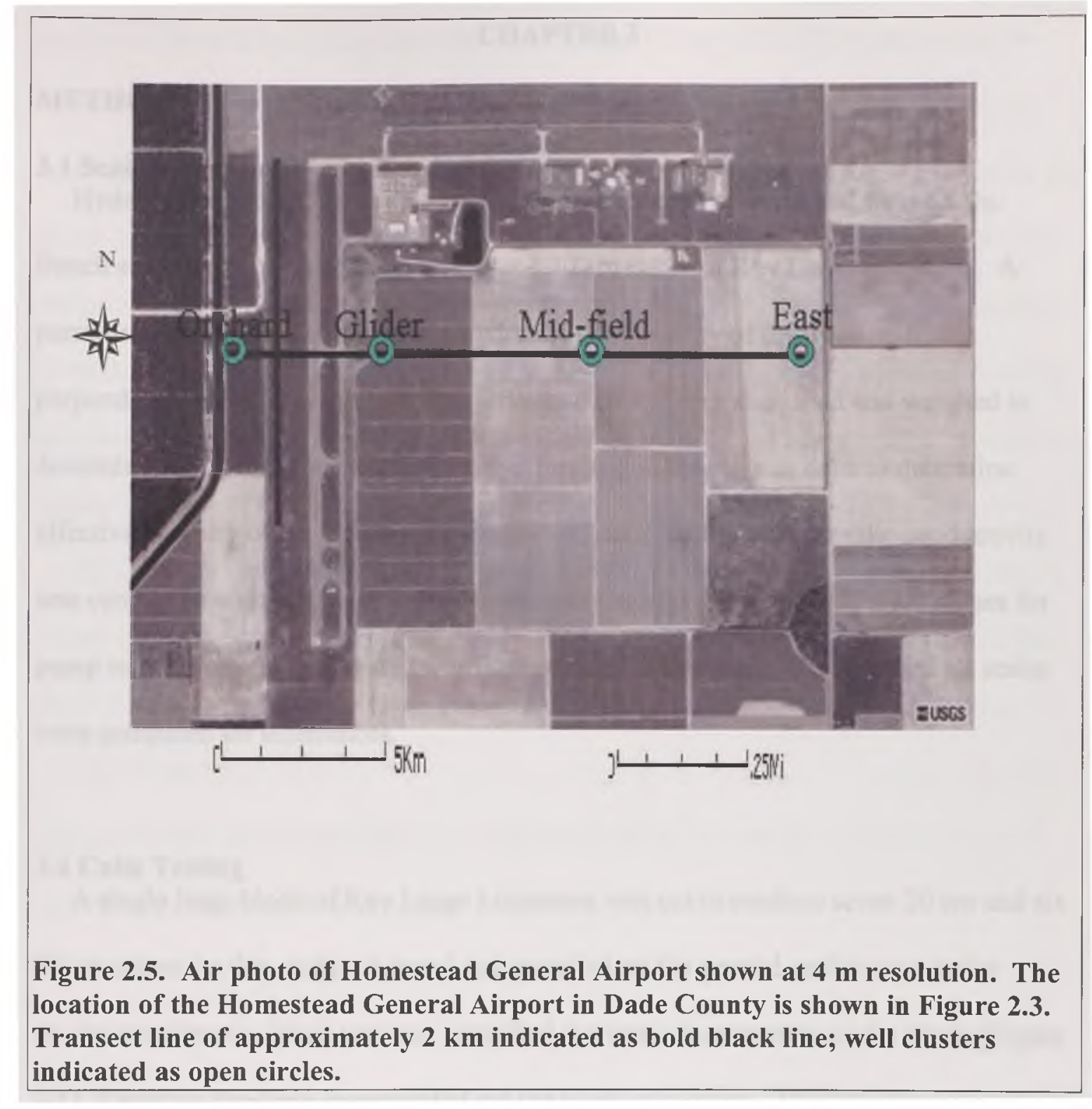




\section{CHAPTER 3}

\section{METHODS}

\subsection{Scale Tested and Technique Used}

Hydraulic conductivity measurements were conducted at bench and field scales.

Bench scale testing was done on $20 \mathrm{~cm}$ and $30 \mathrm{~cm}$ cubes of Key Largo limestone. A permeameter was used to determine hydraulic conductivity of the three mutually perpendicular axes of each cube. The limestone cubes were also dried and weighed to determine bulk density and total porosity. Immersion testing was done to determine effective porosity of the limestone cubes. Field scale testing for hydraulic conductivity was conducted with slug tests at the Homestead General Airport. Field scale values for pump tests conducted in the area were taken from the literature. Results from all scales were compared for differences.

\subsection{Cube Testing}

A single large block of Key Largo Limestone was cut to produce seven $20 \mathrm{~cm}$ and six $30 \mathrm{~cm}$ cubes for this study. A metal rod, installed on the ground surface as a trailer tie-down before the block was cut, identified the vertical orientation of the block (Figure 3.1). Keystone Products Incorporated cut the block into cubes. The first step was to trim unwanted material from one side of the block to make a flat side. The flat side was then laid on a cutting cart and slabs $20 \mathrm{~cm}$ and $30 \mathrm{~cm}$ in width were cut. Individual slabs were laid on separate cutting carts and cut into square columns. Rotating the cart 90 degrees and cutting again at $20 \mathrm{~cm}$ intervals for the $20 \mathrm{~cm}$ column and $30 \mathrm{~cm}$ intervals for the 30 $\mathrm{cm}$ column, produced the $20 \mathrm{~cm}$ and $30 \mathrm{~cm}$ cubes respectively. Cubes were labeled before being removed from the cutting carts to preserve axis orientation as well as the 
position of each cube in relation to the earth surface (Figure 3.2). Cubes closest to the surface were labeled 1 . Cubes immediately beneath cube 1 were labeled 2 . Numbers increased with depth until the final cube was numbered. The column used to produce the $20 \mathrm{~cm}$ cubes was long enough to produce 7 cubes. The column used to produce the 30 $\mathrm{cm}$ cubes was long enough to produce only 5 cubes. The sixth $30 \mathrm{~cm}$ cube was cut from the bottom of the column immediately adjacent to the first column (Figure 3.3). Vertical axes in each cube were labeled as $\mathrm{v}$, while the horizontal axes perpendicular to $\mathrm{v}$ were labeled as $\mathrm{h} 1$ and $\mathrm{h} 2$.

Bulk density was calculated by dividing the weight of each dry cube, in grams, by its volume, in $\mathrm{cm}^{3}$. Cubes were dried at $110^{\circ} \mathrm{c}$. Drying times were 5 days for $20 \mathrm{~cm}$ cubes and 7 days for $30 \mathrm{~cm}$ cubes. Total porosity $\left(\mathrm{n}_{\text {total }}\right)$ was calculated using the equation:

$$
\mathrm{n}_{\mathrm{total}}=1-\left[\mathrm{P}_{\mathrm{b}} / \mathrm{P}_{\mathrm{s}}\right]
$$

where $P_{b}$ refers to the bulk density as determined by the dry weight divided by volume and $P_{s}$ refers to the density of calcite, which is $2.71 \mathrm{~g} / \mathrm{cm}^{3}$.

Effective porosity was calculated in a $0.635 \mathrm{~cm}$ thick $35 \mathrm{~cm}$ by $35 \mathrm{~cm}$ by $60 \mathrm{~cm}$ Plexiglas chamber (Figure 3.4). These measurements allowed the largest limestone cube, $30 \mathrm{~cm}$ by $30 \mathrm{~cm}$ by $30 \mathrm{~cm}$, to fit within the chamber without overflow. A drain valve was installed $34 \mathrm{~cm}$ above the base of the chamber. This height guaranteed that all cubes would be completely submersed during the tests. A cover sealed with $0.635 \mathrm{~cm}$ thick auto gasket material allowed a vacuum to be drawn on the chamber. Vacuum pressure within the chamber was regulated in a $0.635 \mathrm{~cm}$ thick Plexiglas cylinder partially filled with water (Figure 3.5). A hollow rod within the chamber extended $6 \mathrm{~cm}$ below the surface of the water and was open to the atmosphere. Two hoses were connected to the 
top of the chamber, above the water; one went to a vacuum line and the other went to the chamber containing the limestone cube. Vacuum pressure was regulated to insure a constant flow of bubbles into the chamber, thus ensuring vacuum pressure did not exceeded $6 \mathrm{~cm}$ of water. The change in pressure $(\Delta \mathrm{p})$ caused by the $6 \mathrm{~cm}$ of vacuum was determined to be $600 \mathrm{~kg} / \mathrm{ms}$ from the equation:

$$
\Delta \mathrm{p}=\Delta \mathrm{h} \rho \mathrm{g}
$$

where $\Delta h$ refers to the change in head, $\Delta p$ refers to the change in pressure, $\rho$ refers to the density of water $\left(1000 \mathrm{~kg} / \mathrm{m}^{3}\right)$, and $\mathrm{g}$ refers to gravity $\left(10 \mathrm{~m} / \mathrm{s}^{2}\right)$. This value was used in the Laplace equation:

$$
\mathrm{r}=2 \gamma / \Delta \mathrm{p}
$$

where $r$ refers to the radius of the pore to be evacuated, and $\gamma$ refers to the surface tension of water $\left(7.24 \times 10^{-2} \mathrm{~J} / \mathrm{m}^{2}\right)$. In this case $r$ was determined to be $0.02 \mathrm{~cm}$. Multiplying the radius by 2 gave a diameter of $0.04 \mathrm{~cm}$ for the maximum size of a pore that was evacuated by vacuum.

Testing began by setting the water level to the height of the drain. The drain was then closed and the limestone cube immersed. The cover was sealed in place and the chamber was vacuumed for 4 hours. While the limestone cube remained submerged the drain valve was opened. Water exiting the drain was measured until the water level again equaled the height of the drain. The volume collected represented the volume displaced by the limestone cube and the lifting strap. The volume displaced by the lifting strap was subtracted from the total volume displaced, leaving only the volume displaced by the limestone cube. Effective porosity ( $\mathrm{n}_{\text {effective }}$ ) was calculated using the formula:

$$
\mathrm{n}_{\text {effective }}=\left[\mathrm{v}_{\mathrm{e}}-\mathrm{v}_{\mathrm{d}}\right] / \mathrm{v}_{\mathrm{e}}
$$


where $v_{e}$ refers to the volume expected to be displaced and $v_{d}$ refers to the actual volume displaced. The $20 \mathrm{~cm}$ cubes were expected to displace $8,000 \mathrm{~cm}^{3}$, and the $30 \mathrm{~cm}$ cubes were expected to displace $27,000 \mathrm{~cm}^{3}$ of water.

Hydraulic conductivity for each axis was determined using a Plexiglass permeameter assembled around each mutually perpendicular axis of each cube (Figure 3.6, Appendex A). Plastic was wrapped around 4 faces of each cube in preparation for permeameter testing (Appendex A). This left one axis of the cube available for water flow. The cube was then wrapped in a sheet of $0.635 \mathrm{~cm}$ closed cell neoprene rubber. This rubber sheet was covered with $0.635 \mathrm{~cm}$ aluminum plates. Pressure was applied to the aluminum plates using nylon straps tightened with a ratcheting mechanism. This assembly prevented preferential flow around the cube instead of through the cube. Integrity of the assembly was checked after testing by confirming the imprint of the cube in the rubber sheet, confirming that the rubber sheet was dry, and inspecting the plastic wrap for holes. Input and output panels of the box were aligned with the face of the cube and tightened into position with threaded rods. Seams were filled with $100 \%$ silicone and allowed to dry for 12 hours. When the silicone had cured, the permeameter was flooded with water and vacuumed until the cube was saturated. The apparatus was allowed to stand flooded for 12 hours and revacuumed to assure saturation of the cube. A static head difference between the input and output level of approximately $200 \mathrm{~mm}$ for $20 \mathrm{~cm}$ cubes and 300 $\mathrm{mm}$ for $30 \mathrm{~cm}$ cubes was established and water was allowed to flow through the cube for 1 hour until equilibrium was established.

Sampling was conducted by collecting volumes of water discharged at timed intervals at the outflow side of the permeameter. Water collected was weighed on a Denver 
Instruments DI-400 scale. Weight in grams was converted to cubic centimeters.

Temperature of the water collected was $23.5^{\circ} \mathrm{C}$, which gave the water a density of 0.9975 $\mathrm{g} / \mathrm{cm}^{3}$. Converting water with this density to cubic centimeters introduced an error that was less that 1 percent. Volume collected divided by the time of collection gave discharge, or $\mathrm{Q}$, in $\mathrm{cm}^{3} / \mathrm{sec}$. Seven trials were conducted at each static head difference and then averaged to give a discharge value for each head level. Head differences ranging from $25 \mathrm{~mm}$ to $200 \mathrm{~mm}$, in increments of $25 \mathrm{~mm}$, were used for the $20 \mathrm{~cm}$ cubes. Head differences ranging from $50 \mathrm{~mm}$ to $300 \mathrm{~mm}$, in increments of $50 \mathrm{~mm}$, were used for the $30 \mathrm{~cm}$ cubes.

Data were plotted using the product of $\mathrm{A}(\mathrm{dh} / \mathrm{dl})$ as the independent variable and $\mathrm{Q}$ as the dependent variable, where $A$ refers to area of the face of the cube perpendicular to flow, $d h$ refers to the difference in head between the outflow side and inflow side of the permeameter, $d l$ refers to the length of the cube, and $Q$ refers to discharge in $\mathrm{cm}^{3} / \mathrm{sec}$. A trend line passing through the origin was fit to the data points. The slope of the trend line was equal to the hydraulic conductivity of that axis of the cube.

Repeatability of the permeameter was tested prior to conducting experiments. A limestone cube was installed, vacuumed and tested. The cube was allowed to stand for 12 hours and was revacuumed and retested. Values of hydraulic conductivity obtained in both series of tests differed by less than $1 \%$. The permeameter was then disassembled and reassembled around the same axis of the same cube and retested. Hydraulic conductivity values obtained were compared for differences with the previous tests, which would have indicated non-repeatability of results. Again, values of hydraulic conductivity obtained differed by less than $1 \%$. 
High head tests were run in $20 \mathrm{~cm}$ Key Largo Limestone \#7 to confirm Darcian flow was not exceeded. Head levels ranging from $25 \mathrm{~mm}$ to $200 \mathrm{~mm}$ were used in the permeameter. Values obtained were plotted and a best-fit line was generated. Tests were then conducted using $400 \mathrm{~mm}$, twice the length of the cube, and $600 \mathrm{~mm}$, three times the length of the cube. Values from these tests were plotted along with vales of the previous tests. A new best-fit line was generated. The slopes of both best-fit lines were compared for differences. This test was conducted on only one cube because of the excessive strain the high head level exerted on the test equipment.

\subsection{Slug test procedure}

Slug tests were conducted in the wells at Homestead General Airport (Figure 2.5).

Prior to conducting the slug tests each well was surged and pumped until clear water was obtained. Slugs were made from $2.54 \mathrm{~cm}$ diameter schedule $40 \mathrm{PVC}$ pipe. Lengths of 30,45 , and $60 \mathrm{~cm}$ were cut from the pipe. PVC plugs that fit the inside diameter of the pipe were used to seal the slugs. This was done to minimize the outer diameter of the slug thus reducing the chance of pulling the pressure transducer up by its cable during slug extraction. Stainless steel eyebolts were fitted through holes drilled into three of the plugs and secured with stainless steel nuts. These three assemblies were then glued into the top end of each slug with PVC cement. The slugs were filled with cement and the bottom plugs were glued in place with PVC glue. Core and cover nylon line was tied to each eyebolt for lowering and extracting slugs from the wells. The change in water level caused by each slug was measured in the lab in a capped piece of PVC pipe with the same diameter as the wells at Homestead General Airport. 
A Druck IPX-DC pressure transducer was used to measure the change in water levels in the wells during the slug tests. Prior to its use, the pressure transducer was calibrated using a clear plastic tube filled with water. The pressure transducer was lowered into the tube and a measure of its depth was made from the outside of the tube. Simultaneous depth measurements were taken by the pressure transducer and viewed on a Campbell Scientific cr23x data logger. Externally measured depths were compared to pressure transducer measured depths. Differences between the two sets of measurements were found to be less than $0.5 \mathrm{~cm}$. This difference is not significant as tests were run using change in water levels, not absolute water levels.

To calibrate the slugs, water was added to the capped PVC pipe. The pressure transducer was lowered into the PVC pipe to a depth of $1 \mathrm{~m}$ below the water level, which insured the longest slug would not come in contact with the pressure transducer. A slug was then lowered into the PVC pipe until immersed and the change in head level was recorded on a Campbell Scientific cr23x data logger. This procedure was repeated for 5 trials with each slug. The average head change for each slug was calculated. The average head level changes in the wells at Homestead General Airport were $13.5 \mathrm{~cm}$, $19.9 \mathrm{~cm}$, and $26.4 \mathrm{~cm}$ for the $30 \mathrm{~cm}, 45 \mathrm{~cm}$ and $60 \mathrm{~cm}$ slugs respectively (Table 3.1 ).

Slug tests were conducted after the pressure transducer was introduced into the well and secured approximately $2 \mathrm{~m}$ below the height of the water table (Figure 3.7). This was to insure that the oscillations in the water levels caused by removing the slug did not expose the transducer to air. A slug was introduced into the well until the top of the slug was slightly submerged. The head level in the well was allowed to equilibrate.

Equilibrium was determined by monitoring a real time display of water level in the well 
until a constant level was observed. The slug was then rapidly removed. The transducer measured the resulting oscillating head levels. Response of each test was monitored and recorded using a laptop computer at $1 / 50 \mathrm{sec}$ intervals on a Campbell Scientific cr $23 \mathrm{x}$ data logger using Campbell Scientific software. Six trials for each slug size were performed on each well.

Water levels obtained from the tests were transferred to Microsoft Excel files. The water levels were normalized by dividing the measured change in head level by the change in head level the slug was known to make. The normalized data were plotted with time as the independent variable and normalized head height as the dependent variable. Results plotted as an oscillating curve where the amplitude of the oscillation diminished with time. Slug tests were analyzed to determine hydraulic conductivity using the Butler spreadsheet method for analyzing partially penetrating wells in highly transmissive aquifers (Butler, 2003). Using this method a curve was generated to match the curve of the data (Figure 3.8). Best fit was determined by minimizing the difference between maxima and minima points of the two curves.

\subsection{Statistical Analysis}

Mean hydraulic conductivity values at increasing scales were compared for differences. Scales used were $20 \mathrm{~cm}$ cubes, $30 \mathrm{~cm}$ cubes, 1.5 meters of screen length for slug tests, and aquifer scale pumping tests. Also mean hydraulic conductivity values of each axis of each sized cube were compared for differences. Mean hydraulic conductivity values of each well cluster at the Homestead General Airport were 
compared for differences. Mean hydraulic conductivity values for each size slug were also compared for differences.

Analysis of variance statistics and plots were performed on permeameter and slug test data using SigmaPlot and Statistical Package for the Social Sciences (SPSS) programs. Permeameter data were analyzed to determine differences amongst individual cubes, amongst the vertical, h1 and h2 axes, and amongst $20 \mathrm{~cm}$ and $30 \mathrm{~cm}$ cubes. Slug test data were analyzed to determine differences amongst well clusters and amongst slug sizes used. Differences were considered significant at the 0.05 probability level. Hydraulic conductivity values for all scales were tested for differences. 
Table 3.1 Head level changes, in $\mathrm{cm}$, caused by immersing each slug into a $5.08 \mathrm{~cm} \mathrm{PVC}$ well.

\begin{tabular}{|c|c|c|c|}
\hline \multicolumn{4}{|c|}{ Slug Calibration } \\
\hline Trial & $30 \mathrm{~cm}$ slug & $45 \mathrm{~cm} \mathrm{slug}$ & $60 \mathrm{~cm}$ slug \\
\hline 1 & 13.607 & 19.947 & 26.517 \\
\hline 2 & 13.568 & 19.827 & 26.422 \\
\hline 3 & 13.569 & 19.888 & 26.477 \\
\hline 4 & 13.578 & 19.927 & 26.406 \\
\hline 5 & 13.584 & 20.037 & 26.366 \\
\hline avg & 13.581 & 19.925 & 26.437 \\
\hline st. dev. & 0.0141 & 0.0692 & 0.0533 \\
\hline
\end{tabular}




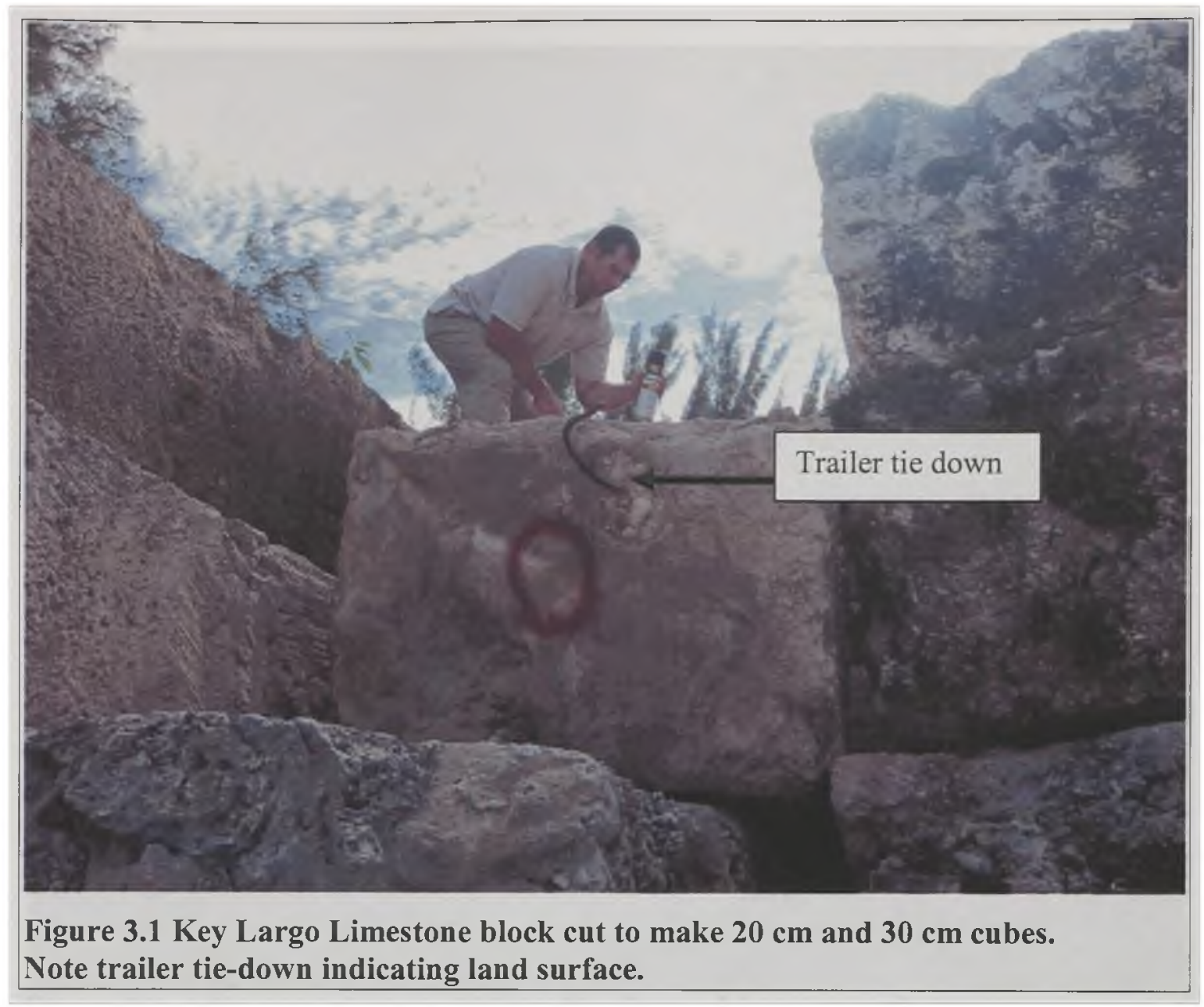




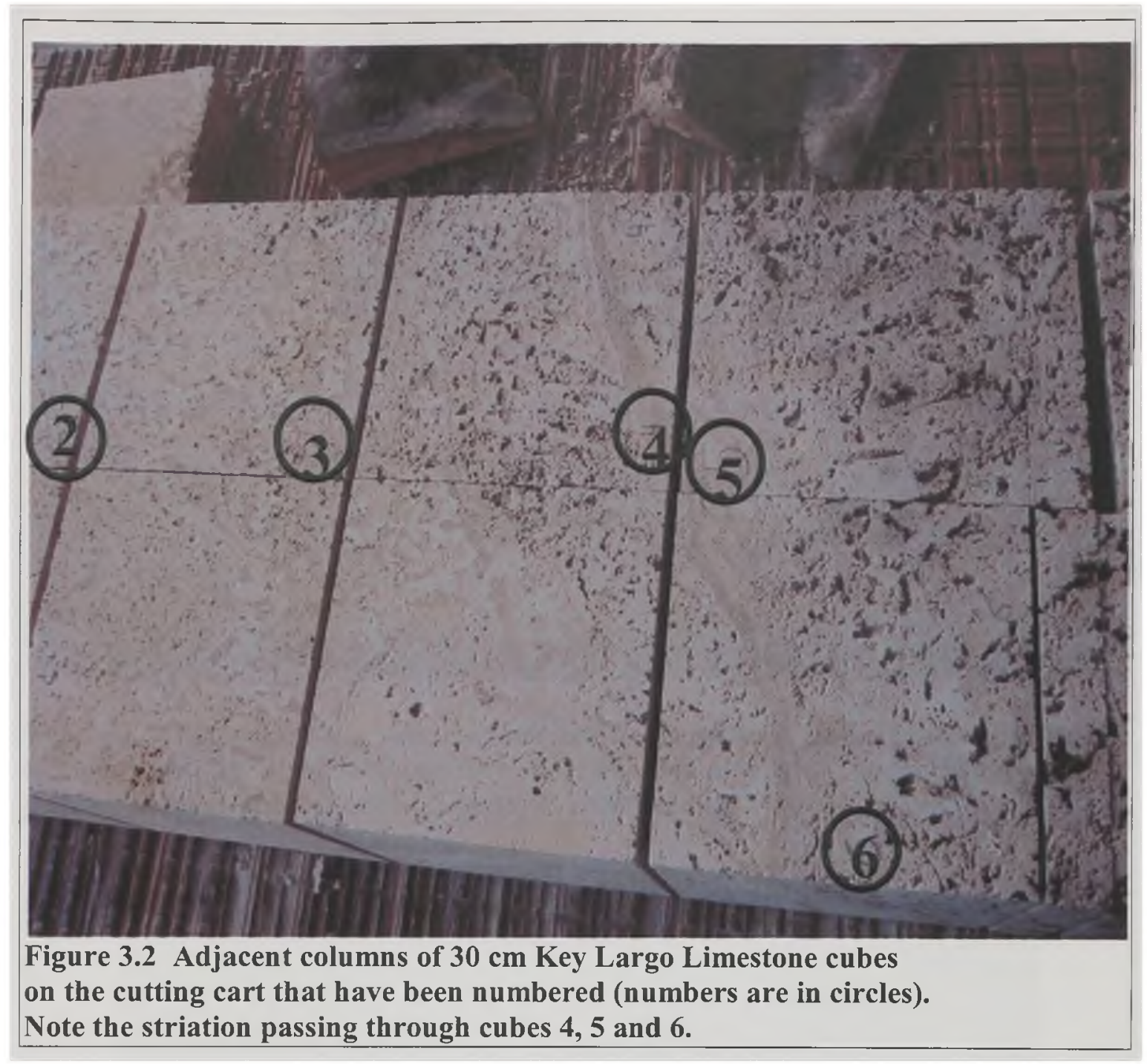




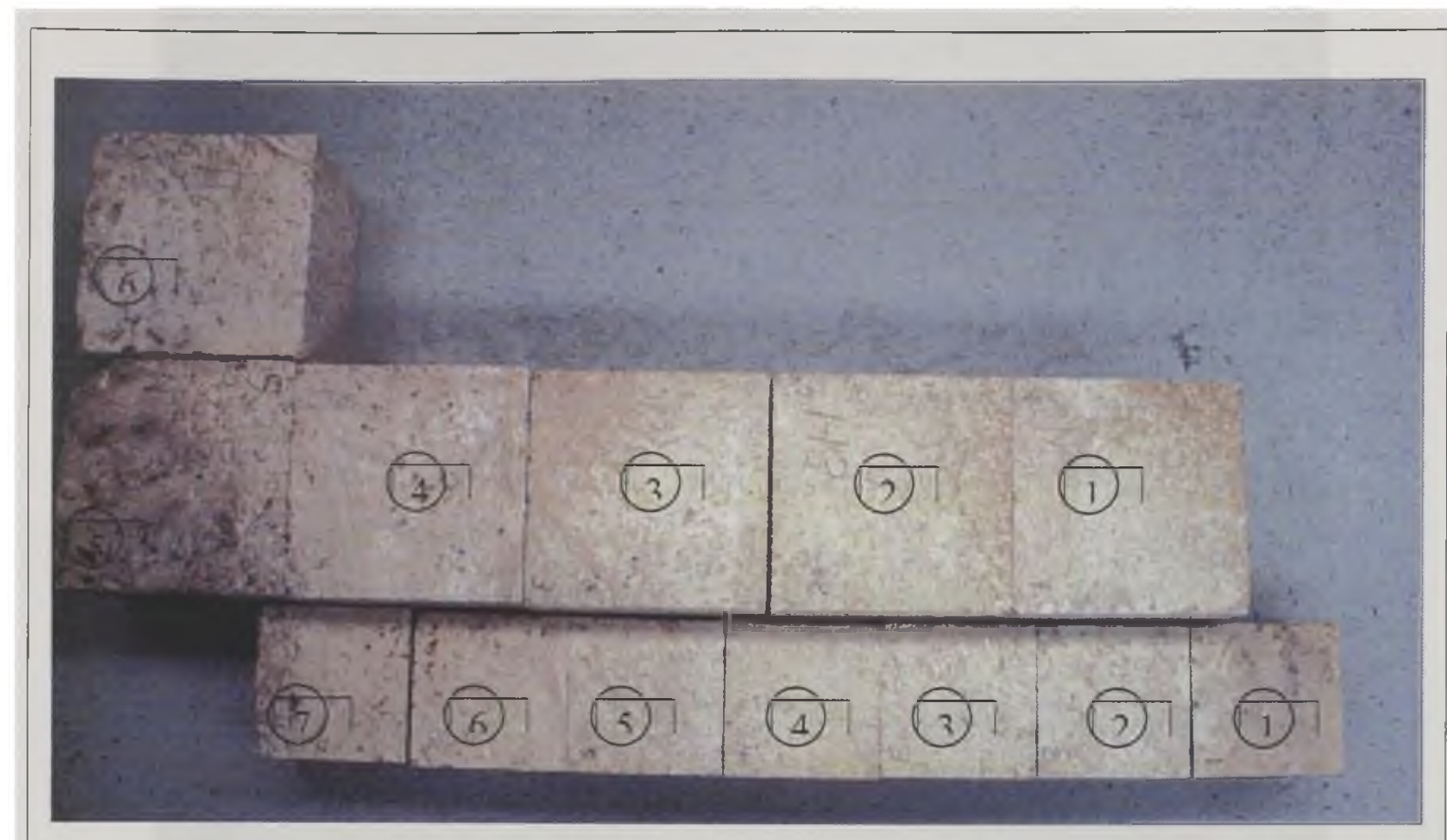

Figure 3.3 Photo showing cubes in their relative positions. Cubes to the right would have been closest to the lands surface. The dense laminated layer can be seen passing through the left cube (deepest) in each column. 


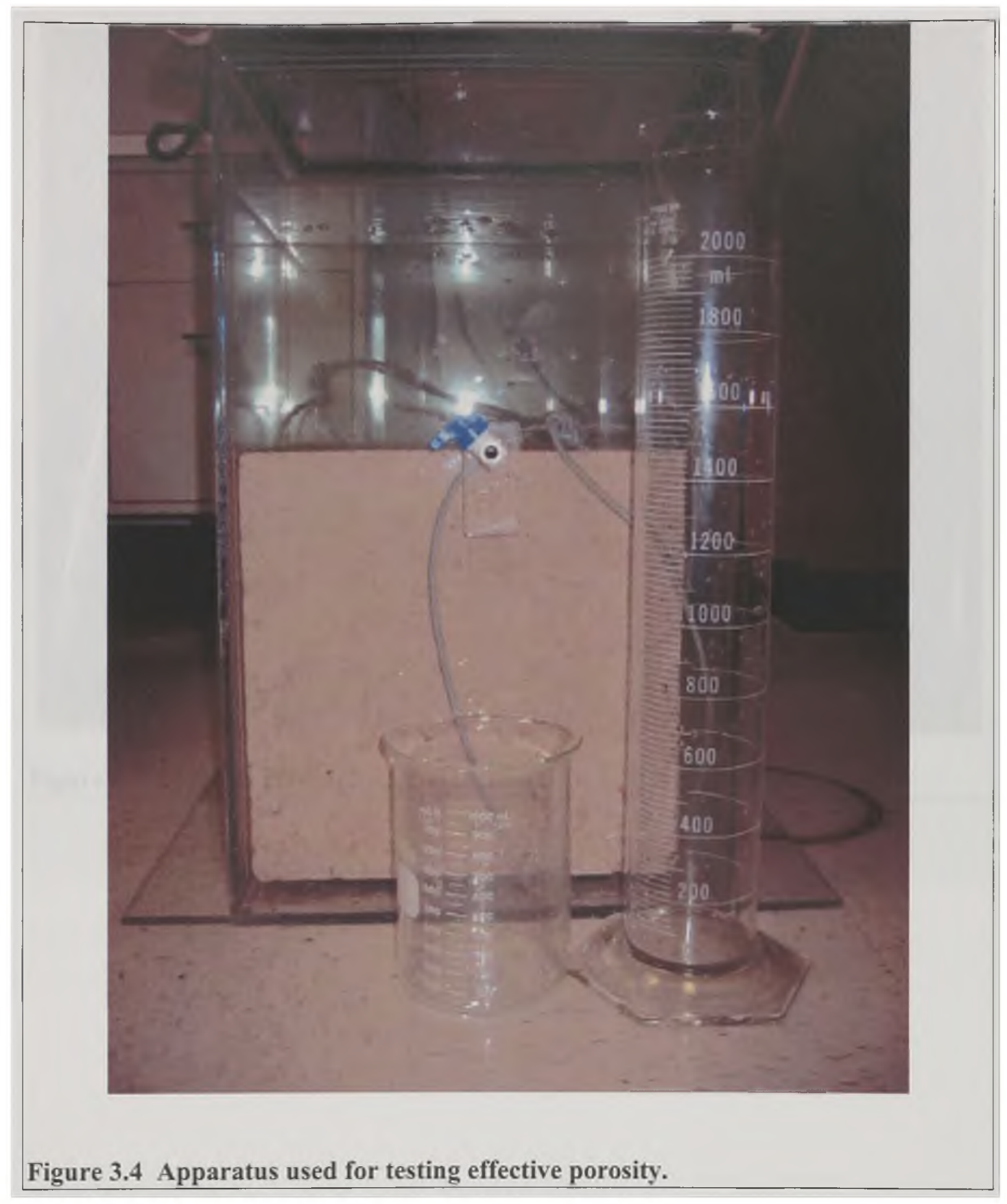




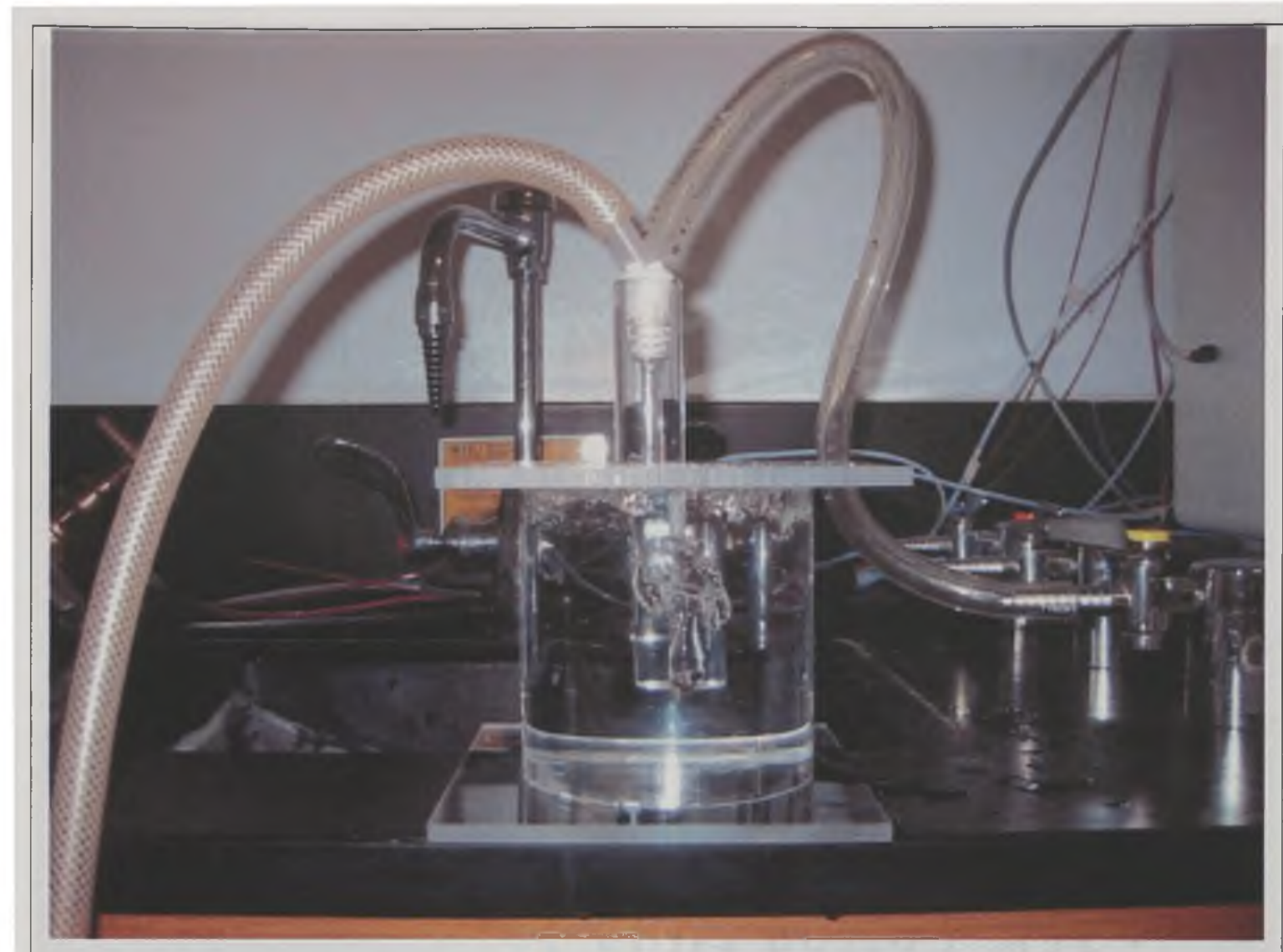

Figure 3.5 Vacuum pressure regulator used to maintain constant pressure. 


\section{$\mathrm{Q}=-\mathrm{KA}(\mathrm{dh} / \mathrm{dl})$}

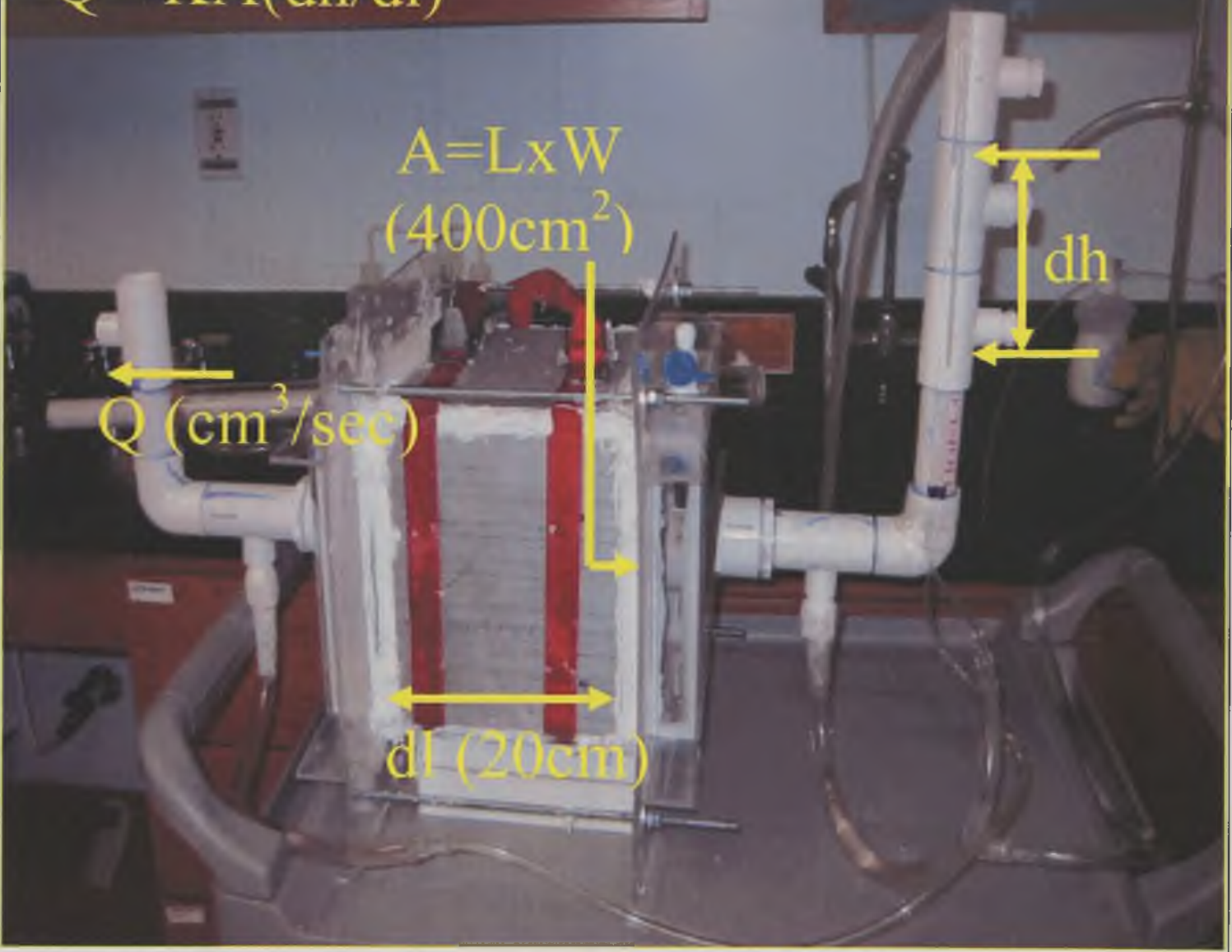

Figure 3.6 Permeameter used on $20 \mathrm{~cm}$ and $30 \mathrm{~cm}$ Key Largo Limestone cubes. 


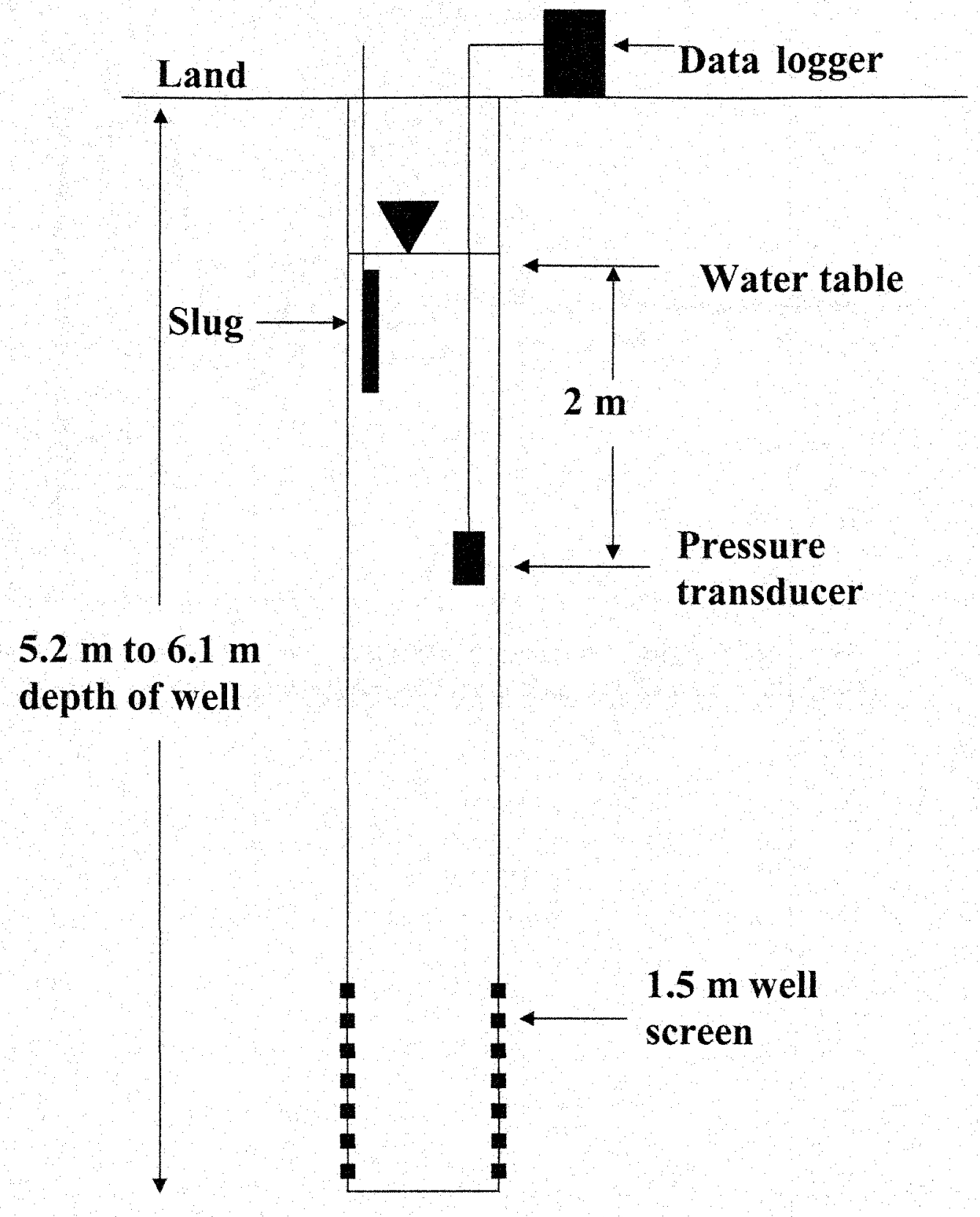

Figure 3.7 Diagram showing slug test set up. 


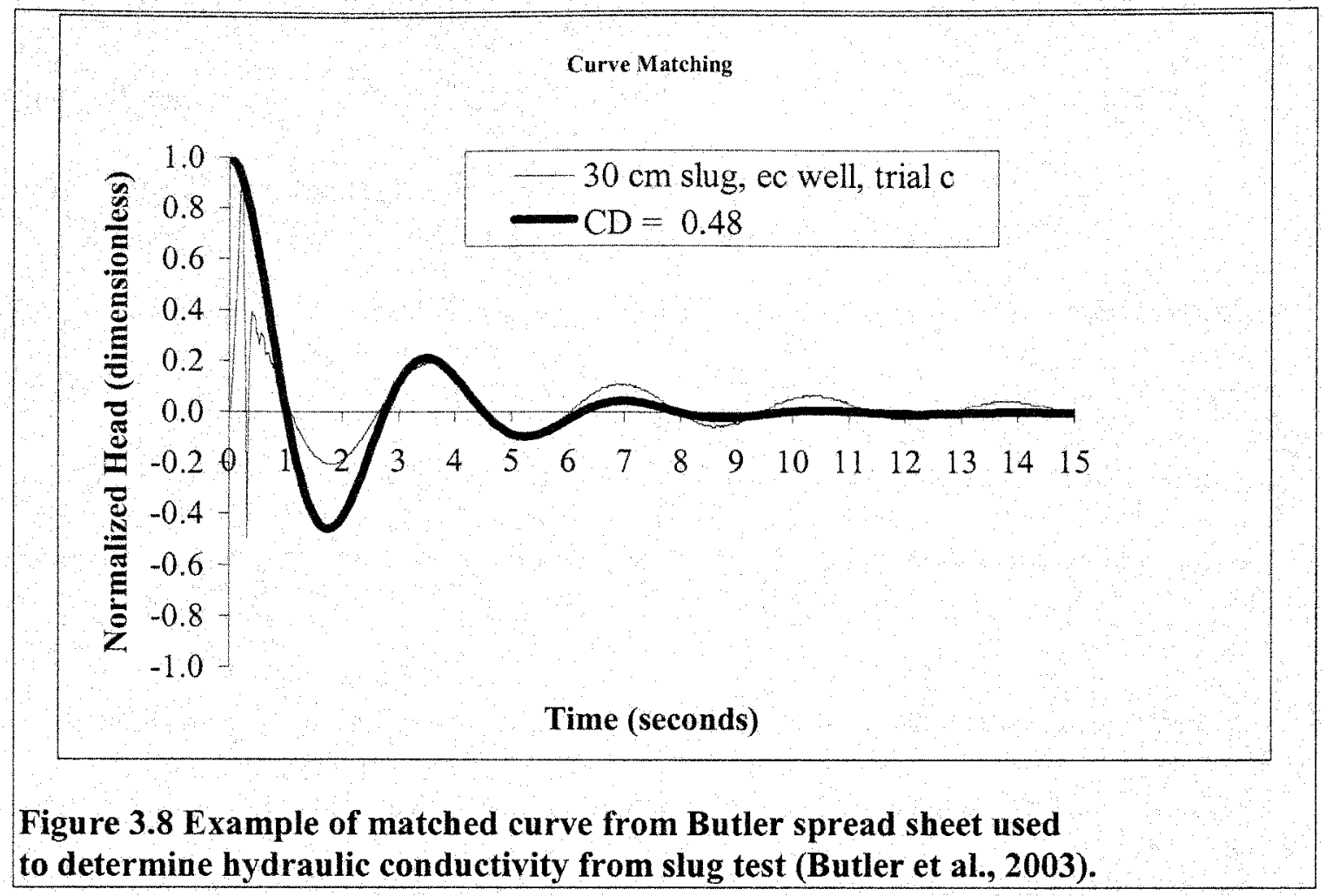




\section{CHAPTER 4}

\section{RESULTS}

\subsection{Cubes of Key Largo Limestone}

Bulk density values for the $20 \mathrm{~cm}$ Key Largo Limestone cubes range from a low of 1.4 $\mathrm{g} / \mathrm{cm}^{3}$ to a high of $1.9 \mathrm{~g} / \mathrm{cm}^{3}$ (Table 4.1 ). Total porosity values for these cubes ranged from a low of 0.30 to a high of 0.49 (Table 4.1). Bulk density values for the $30 \mathrm{~cm} \mathrm{Key}$ Largo Limestone cubes range from a low of $1.2 \mathrm{~g} / \mathrm{cm}^{3}$ to a high of $1.6 \mathrm{~g} / \mathrm{cm}^{3}$ (Table 4.2 ). Total porosity values for these cubes ranged from a low of 0.39 to a high of 0.54 (Table 4.2).

Effective porosity values for the $20 \mathrm{~cm}$ Key Largo Limestone cubes ranged from a low of 0.16 to a high of 0.34 (Table 4.1 ). Effective porosity values for the $30 \mathrm{~cm}$ Key Largo Limestone cubes ranged from a low of 0.25 to a high of 0.38 (Table 4.2). There was a positive relationship between total porosity and effective porosity (Figure 4.1).

Hydraulic conductivity for each axis of each cube was determined by the slope of the best-fit line generated by plotting average discharges $(\mathrm{Q})$ from the permeameter versus A(dh/dl) of each trial (Table 4.3; Figure 4.2, Appendix B). The $20 \mathrm{~cm}$ Key Largo Limestone cubes have hydraulic conductivity values that range from a low of $0.48 \mathrm{~m} /$ day to a high of $38 \mathrm{~m}$ /day (Table 4.4; Table 4.5; Figure 4.3; Figure 4.4). Averaging all three axes in each cube gave the average for that cube. Arithmetic average values range from a low of $0.74 \mathrm{~m} /$ day to a high of $32 \mathrm{~m} /$ day (Table 4.6; Table 4.7; Figure 4.5). Geometric means were similar to the arithmetic average and varied from 0.17 to $32 \mathrm{~m} /$ day (Table 4.6). 
Mean hydraulic conductivity values of all $20 \mathrm{~cm}$ cubes were compared for differences. There was a significant difference at the 0.05 level between cube 6 and all the other cubes and between cube 7 and cubes 2, 3, 4, 5, and 6 (Figure 4.3; Figure 4.4). Mean hydraulic conductivity values of each axis of all the $20 \mathrm{~cm}$ cubes were compared for differences. There was no significant difference at the 0.05 level between axes (Figure 4.5). However, comparing the vertical axis to the average of the horizontal axes within each cube shows anisotropy. Cubes 1, 3 and 5 show preferential flow in their vertical axis, cubes 2 and 6 show no anisotropy while cubes 4 and 7 show preferential flow in the horizontal axis (Figure 4.6).

The $30 \mathrm{~cm}$ Key Largo Limestone cubes have hydraulic conductivity values that range from a low of $0.23 \mathrm{~m} /$ day to a high of $67 \mathrm{~m} /$ day (Table 4.8; Table 4.9; Figure 4.7; Figure 4.8). Averaging all three axes in each cube gave the average for that cube. Average values range from a low of $0.39 \mathrm{~m} /$ day to a high of $46 \mathrm{~m} /$ day (Table 4.10 ; Table 4.11 ; Figure 4.9). Mean hydraulic conductivity values of all $30 \mathrm{~cm}$ cubes were compared for differences. There was significant difference at the 0.05 level between cube 5 and cubes 1, 2,3, and 4 (Figure 4.7; Figure 4.8). Mean hydraulic conductivity values of each axis of all the $30 \mathrm{~cm}$ cubes were compared for differences. There was no significant difference at the 0.05 level between axes (Figure 4.9). However, comparing the vertical axis to the average of the horizontal axes within each cube shows anisotropy. Cubes 1 and 2 show preferential flow in their vertical axis, cubes 3 and 4 show no anisotropy, while cubes 5 and 6 show preferential flow in their horizontal axis (Figure 4.10).

There was no detectable change in the slope of the best-fit lines for the cube tested with and without the high head conditions. The resulting hydraulic conductivity value for 
both situations was $10 \mathrm{~m} /$ day. The best-fit lines had $\mathrm{R}^{2}$ values of .99 and 1.0 for the data without and with the high heads, respectively. In addition, all of the data points for these tests fell within the 95 percent confidence intervals around the best-fit line (Figure 4.11, Figure 4.12).

The relationship between effective porosity and hydraulic conductivity did not remain the same for all the cubes. Increases in effective porosity caused virtually no increase in hydraulic conductivity below approximately 33 percent effective porosity. However, above approximately 33 percent effective porosity, small increases in effective porosity caused large increases in hydraulic conductivity (Figure 4.13).

Approximately one third of the plots used to determine hydraulic conductivity showed a slight curvature of the data points relative to the best-fit straight line. To assess if this indicated a deviation from Darcian flow, Reynolds numbers were calculated.

Reynolds number calculations were made using the formulas

$$
6 \mathrm{p}=\rho g 6 \mathrm{~h}
$$

where $6 p$ refers to change in pressure, $\rho$ refers to density of water $\left(1000 \mathrm{~kg} / \mathrm{m}^{3}\right), g$ refers to gravity $\left(9.8 \mathrm{~m} / \mathrm{s}^{2}\right)$ and $6 h$ refers to the change in head.

$$
\mathrm{V}_{\mathrm{avg}}=6 \mathrm{pr}^{2} / 618 \mu
$$

where $V_{\text {avg }}$ refers to the average velocity in $\mathrm{m} / \mathrm{s}, 6 p$ refers to change in pressure, $r$ refers to the radius in $\mathrm{m}, 6 l$ refers to the change in length in $\mathrm{m}$, and $\mu$ refers to the viscosity of water $\left(7.27 \times 10^{-2} \mathrm{~kg} / \mathrm{sm}\right)$. Values from these calculations were used in the formula;

$$
\mathrm{R}=\mathrm{Pvd} / \mu
$$


where $R$ refers to the Reynolds number, $v$ refers to average velocity in $\mathrm{m} / \mathrm{s}, d$ refers to diameter in $\mathrm{m}$, and $\mu$ refers to viscosity of water $\left(7.27 \times 10^{-2} \mathrm{~kg} / \mathrm{sm}\right)$. Values obtained across three orders of magnitude of head levels $(0.002$ to $0.2 \mathrm{~m}$ ) for $20 \mathrm{~cm}$ Key Largo Limestone cubes and 0.003 to $0.3 \mathrm{~m}$ for $30 \mathrm{~cm}$ Key Largo Limestone cubes (Figure 4.14, Figure 4.15). Darcy's law is valid only under laminar flow conditions and when there is a linear relationship between specific discharge and hydraulic gradient (Figure 4.16). These conditions tend to occur at low Reynold's numbers of less than 5 (Freeze and Cherry, 1979). At higher Reynold's Numbers Darcian flow is exceeded and turbulent flow is occurring (Figure 4.14, Figure 4.15). Figures 4.12 and 4.13 show that Reynolds numbers of approximately 5 are the upper limit of linear laminar flow, for head differences of $.002 \mathrm{~m}$ to $.2 \mathrm{~m}$, where Darcy's Law is valid (Figure 4.16). The highest head levels used in these experiments $(.02 \mathrm{~m}$ for $20 \mathrm{~cm}$ cubes, $.03 \mathrm{~m}$ for $30 \mathrm{~cm}$ cubes, and $.06 \mathrm{~m}$ for the high head test) combined with the observed pore sizes in the Key Largo Limestone cubes give Reynolds numbers less than 5. This is a Reynolds number value low enough to be within the range of laminar flow. This is of significance because data were used to calculate hydraulic conductivity values using Darcy's Law, which is valid only under Darcian flow conditions.

\subsection{Hydraulic conductivity from slug tests}

The slug tests performed at the Homestead General Airport in the Miami Oolite Formation gave hydraulic conductivity values that range from $100 \mathrm{~m}$ /day to $200 \mathrm{~m} /$ day (Table 4.12; Table 4.13; Figure 4.17). ANOVA comparisons of the average value of each well cluster determined that there was significant difference at the 0.05 level 
between the pairs of well clusters East and Glider and the pair of Midfield and Orchard

(Figure 4.17). ANOVA comparisons of the average value of each size slug determined that there was significant difference at the 0.05 level between the $30 \mathrm{~cm}$ slug and the 60 cm slug (Table 4.14; Table 4.15; Figure 4.18).

Table 4.1 Bulk density, total porosity, and effective porosity values for $8,000 \mathrm{~cm}^{3} \mathrm{Key}$ Largo Limestone cubes

\begin{tabular}{|c|c|c|c|c|}
\hline \multicolumn{5}{|c|}{ Bulk Density, Total Porosity, Effective Porosity } \\
\hline $\begin{array}{c}20 \mathrm{~cm} \\
\text { cube }\end{array}$ & weight $(\mathrm{g})$ & bulk density $\left(\mathrm{g} / \mathrm{cm}^{3}\right)$ & total porosity & $\begin{array}{c}\text { effective } \\
\text { porosity }\end{array}$ \\
\hline 1 & 11566 & 1.4459 & 0.47 & 0.32 \\
\hline 2 & 15138 & 1.8924 & 0.30 & 0.16 \\
\hline 3 & 14061 & 1.7577 & 0.35 & 0.20 \\
\hline 4 & 12077 & 1.5096 & 0.44 & 0.29 \\
\hline 5 & 11736 & 1.4671 & 0.46 & 0.30 \\
\hline 6 & 10999 & 1.3750 & 0.49 & 0.34 \\
\hline 7 & 11566 & 1.4459 & 0.47 & 0.33 \\
\hline avg & & & 0.43 & 0.28 \\
\hline
\end{tabular}

Table 4.2 Bulk density, total porosity, and effective porosity for $27,000 \mathrm{~cm}^{3}$ Key Largo Limestone cubes

\begin{tabular}{|c|c|c|c|c|}
\hline \multicolumn{5}{|c|}{ Bulk Density, Total Porosity, Effective Porosity } \\
\hline $\begin{array}{c}30 \mathrm{~cm} \\
\text { cube }\end{array}$ & weight $(\mathrm{g})$ & bulk density $\left(\mathrm{g} / \mathrm{cm}^{3}\right)$ & total porosity & $\begin{array}{c}\text { effective } \\
\text { porosity }\end{array}$ \\
\hline 1 & 43545 & 1.6128 & 0.40 & 0.27 \\
\hline 2 & 44271 & 1.6397 & 0.39 & 0.25 \\
\hline 3 & 38147 & 1.4129 & 0.48 & 0.32 \\
\hline 4 & 37989 & 1.4070 & 0.48 & 0.32 \\
\hline 5 & 33453 & 1.2390 & 0.54 & 0.38 \\
\hline 6 & 36174 & 1.3398 & 0.51 & 0.33 \\
\hline avg & & & 0.47 & 0.31 \\
\hline
\end{tabular}


Table 4.3 Data used to plot Figure 4.5 from $20 \mathrm{~cm}$ Key Largo Limestone cube \#1 with flow along the $\mathrm{h} 1$ axis

\begin{tabular}{|c|c|}
\hline $\mathrm{A}(\mathrm{dh} / \mathrm{dl})\left(\mathrm{m}^{2}\right)$ & $\mathrm{Q}\left(\mathrm{m}^{3} / \mathrm{day}\right)$ \\
\hline 0.0396 & 0.2756 \\
\hline 0.0350 & 0.2513 \\
\hline 0.0298 & 0.2200 \\
\hline 0.0250 & 0.1890 \\
\hline 0.0200 & 0.1553 \\
\hline 0.0150 & 0.1220 \\
\hline 0.0098 & 0.0853 \\
\hline 0.0049 & 0.0452 \\
\hline
\end{tabular}

Table 4.4 Hydraulic conductivity values for all axes of all $20 \mathrm{~cm}$ Key Largo Limestone cubes.

\begin{tabular}{|c|c|c|c|}
\hline \multicolumn{4}{|c|}{$20 \mathrm{~cm}$ Key Largo Limestone cubes } \\
\hline Cube \# & Axis & $\mathrm{K}$ (m/day) & $\mathrm{R}^{2}$ \\
\hline \multirow{3}{*}{1} & $\mathrm{~V}$ & 8.2 & 0.73 \\
\hline & h1 & 7.3 & 0.98 \\
\hline & h2 & 2.6 & 0.78 \\
\hline \multirow{3}{*}{2} & $\mathrm{v}$ & 0.79 & 0.98 \\
\hline & h1 & 0.93 & 0.95 \\
\hline & $\mathrm{h} 2$ & 0.48 & 0.80 \\
\hline \multirow{3}{*}{3} & $\mathrm{v}$ & 2.4 & 0.99 \\
\hline & h1 & 1.7 & 0.93 \\
\hline & h2 & 0.79 & 0.77 \\
\hline \multirow{3}{*}{4} & $\mathrm{v}$ & 2.0 & 0.99 \\
\hline & h1 & 3.7 & 0.99 \\
\hline & $\mathrm{h} 2$ & 4.1 & 0.95 \\
\hline \multirow{3}{*}{5} & $\vee$ & 8.3 & 0.91 \\
\hline & h1 & 4.9 & 0.99 \\
\hline & h2 & 3.2 & 0.99 \\
\hline \multirow{3}{*}{6} & $\mathrm{v}$ & 33 & 0.94 \\
\hline & h1 & 38 & 0.89 \\
\hline & $\mathrm{h} 2$ & 27 & 0.96 \\
\hline \multirow{5}{*}{7} & $\mathrm{v}$ & 10 & 0.98 \\
\hline & h1 & 19 & 0.94 \\
\hline & $\mathrm{h} 2$ & 13 & 0.96 \\
\hline & avg & 9.2 & \\
\hline & st dev & 11 & \\
\hline
\end{tabular}


Table 4.5 Statistics for Table 4.4; Figure 4.4

\begin{tabular}{|l|c|c|c|c|c|c|c|}
\hline Cube \# & $20 \# 1$ & $20 \# 2$ & $20 \# 3$ & $20 \# 4$ & $20 \# 5$ & $20 \# 6$ & $20 \# 7$ \\
\hline Mean & 6.0 & 0.74 & 1.6 & 3.2 & 5.4 & 32 & 14 \\
\hline Std. Dev & 3.00 & 0.221 & 0.870 & 1.10 & 2.58 & 5.50 & 4.58 \\
\hline Std. Err & 1.73 & 0.127 & 0.502 & 0.636 & 1.49 & 3.17 & 2.64 \\
\hline $95 \%$ Conf & 7.45 & 0.548 & 2.15 & 2.73 & 6.41 & 13.6 & 11.3 \\
\hline $99 \%$ Conf & 16.9 & 1.24 & 4.91 & 6.22 & 14.6 & 31.1 & 25.8 \\
\hline Size & 3 & 3 & 3 & 3 & 3 & 3 & 3 \\
\hline Total & 18.1 & 2.23 & 5.07 & 9.80 & 16.2 & 98.0 & 42.0 \\
\hline Minimum & 2.6 & 0.51 & 0.77 & 2.0 & 3.1 & 27 & 10 \\
\hline Maximum & 8.2 & 0.95 & 2.5 & 4.0 & 8.0 & 38 & 19 \\
\hline
\end{tabular}

Table 4.6 Hydraulic conductivity values of each $20 \mathrm{~cm}$ Key Largo Limestone cube.

\begin{tabular}{|c|c|c|}
\hline \multicolumn{3}{|c|}{$20 \mathrm{~cm}$ Key Largo Limestone cubes average hydraulic conductivity (m/day) } \\
\hline cube \# & arithmetic avg of $\mathrm{v}, \mathrm{h} 1, \mathrm{~h} 2$ & $\begin{array}{c}\text { geometric avg of } \mathrm{v}, \mathrm{h} 1 \text {, } \\
\mathrm{h} 2\end{array}$ \\
\hline 1 & 6.0 & 5.3 \\
\hline 2 & 0.74 & 0.71 \\
\hline 3 & 1.6 & 1.5 \\
\hline 4 & 3.2 & 3.1 \\
\hline 5 & 5.4 & 4.9 \\
\hline 6 & 32 & 32 \\
\hline 7 & 14 & 13 \\
\hline
\end{tabular}

Table 4.7 Statistics for Table 4.6; Figure 4.6

\begin{tabular}{|l|c|c|c|}
\hline & $\begin{array}{c}20 \mathrm{~cm} \text { Key Largo } \\
\text { Limestone v axis }\end{array}$ & $\begin{array}{c}20 \mathrm{~cm} \text { Key Largo } \\
\text { Limestone h1 axis }\end{array}$ & $\begin{array}{c}20 \mathrm{~cm} \text { Key Largo } \\
\text { Limestone h2 } \\
\text { axis }\end{array}$ \\
\hline Mean & 9.2 & 10 & 7.2 \\
\hline Std. Dev & 11.0 & 13.4 & 9.66 \\
\hline Std. Err & 4.18 & 5.07 & 3.65 \\
\hline $95 \%$ Conf & 10.2 & 12.4 & 8.93 \\
\hline $99 \%$ Conf & 15.5 & 18.8 & 13.5 \\
\hline Size & 7 & 7 & 7 \\
\hline Total & 64.6 & 75.7 & 50.9 \\
\hline Minimum & 0.77 & 0.95 & 0.51 \\
\hline Maximum & 33 & 38 & 27 \\
\hline
\end{tabular}


Table 4.8 Hydraulic conductivity values for all axes of all $30 \mathrm{~cm}$ Key Largo Limestone cubes.

\begin{tabular}{|c|c|c|c|}
\hline \multicolumn{4}{|c|}{$30 \mathrm{~cm}$ Key Largo Limestone cubes } \\
\hline cube \# & axis & $\mathrm{K}$ (m/day) & $\mathrm{R}^{2}$ \\
\hline \multirow{3}{*}{1} & $\mathrm{v}$ & 2.5 & 0.99 \\
\hline & h1 & 0.74 & 0.97 \\
\hline & h2 & 0.48 & 0.99 \\
\hline \multirow{3}{*}{2} & $\mathrm{v}$ & 0.72 & 0.91 \\
\hline & h1 & 0.23 & 0.99 \\
\hline & h2 & 0.28 & 0.99 \\
\hline \multirow{3}{*}{3} & $\mathrm{v}$ & 0.66 & 0.99 \\
\hline & h1 & 1.3 & 0.99 \\
\hline & h2 & 0.46 & 0.98 \\
\hline \multirow{3}{*}{4} & $V$ & 2.0 & 0.99 \\
\hline & h1 & 2.8 & 0.99 \\
\hline & h2 & 1.8 & 0.99 \\
\hline \multirow{3}{*}{5} & $\mathrm{v}$ & 7.1 & 0.83 \\
\hline & h1 & 67 & 0.83 \\
\hline & h2 & 66 & 0.78 \\
\hline \multirow{5}{*}{6} & $\mathrm{v}$ & 0.81 & 0.99 \\
\hline & hl & 22 & 0.95 \\
\hline & $\mathrm{h} 2$ & 17 & 0.87 \\
\hline & avg & 10 & \\
\hline & st dev & 21 & \\
\hline
\end{tabular}

Table 4.9 Statistics for Table 4.8; Figure 4.8

\begin{tabular}{|l|c|c|c|c|c|c|}
\hline Cube \# & $30 \# 1$ & $30 \# 2$ & $30 \# 3$ & $30 \# 4$ & $30 \# 5$ & $30 \# 6$ \\
\hline Mean & 1.2 & 0.39 & 0.80 & 2.2 & 46 & 13 \\
\hline Std. Dev & 1.08 & 0.254 & 0.446 & 0.529 & 34.2 & 11.0 \\
\hline Std. Err & 0.624 & 0.146 & 0.257 & 0.305 & 19.8 & 6.40 \\
\hline $95 \%$ Conf & 2.68 & 0.629 & 1.10 & 1.31 & 85.0 & 27.5 \\
\hline $99 \%$ Conf & 6.10 & 1.43 & 2.52 & 2.98 & 193 & 62.6 \\
\hline Size & 3 & 3 & 3 & 3 & 3 & 3 \\
\hline Total & 3.78 & 1.19 & 2.42 & 6.60 & 140 & 39.7 \\
\hline Mininum & 0.51 & 0.25 & 0.43 & 1.8 & 7.1 & 0.77 \\
\hline Maximum & 2.5 & 0.69 & 1.3 & 2.8 & 67 & 22 \\
\hline
\end{tabular}


Table 4.10 Hydraulic conductivity values of each $30 \mathrm{~cm}$ Key Largo Limestone cube.

\begin{tabular}{|c|c|c|}
\hline \multicolumn{2}{|c|}{$30 \mathrm{~cm}$ Key Largo Limestone Cubes average hydraulic conductivity (m/day) } \\
\hline \multirow{2}{*}{ cube \# } & arithmetic avg of $\mathrm{v}, \mathrm{h} 1, \mathrm{~h} 2$ & $\begin{array}{c}\text { geometric avg of } \mathrm{v}, \mathrm{h} 1, \\
\mathrm{~h} 2\end{array}$ \\
\hline 1 & 1.2 & 0.99 \\
\hline 2 & 0.39 & 0.35 \\
\hline 3 & 0.8 & 0.72 \\
\hline 4 & 2.2 & 2.1 \\
\hline 5 & 46 & 31 \\
\hline 6 & 13 & 6.6 \\
\hline
\end{tabular}

Table 4.11 Statistics for Table 4.10; Figure 4.10

\begin{tabular}{|l|c|c|c|}
\hline & $\begin{array}{c}30 \mathrm{~cm} \text { Key Largo } \\
\text { Limestone v axis }\end{array}$ & $\begin{array}{c}30 \mathrm{~cm} \text { Key Largo } \\
\text { Limestone hl axis }\end{array}$ & $\begin{array}{c}30 \mathrm{~cm} \text { Key } \\
\text { Largo } \\
\text { Limestone } \mathrm{h} 2 \\
\text { axis }\end{array}$ \\
\hline Mean & 2.2 & 15 & 14 \\
\hline Std. Dev & 2.47 & 26.4 & 26.1 \\
\hline Std. Err & 1.01 & 10.8 & 10.6 \\
\hline $95 \%$ Conf & 2.60 & 27.7 & 27.4 \\
\hline $99 \%$ Conf & 4.07 & 43.5 & 43.0 \\
\hline Size & 6 & 6 & 6 \\
\hline Total & 13.7 & 94.1 & 85.9 \\
\hline Minimum & 0.69 & 0.25 & 0.25 \\
\hline Maximum & 7.1 & 67 & 66 \\
\hline
\end{tabular}

Table 4.12 Hydraulic conductivity values for each well with each size slug.

\begin{tabular}{|c|c|c|c|c|}
\hline \multicolumn{5}{|c|}{ Slug test hydraulic conductivity in m/day } \\
\hline Cluster & Well & $30 \mathrm{~cm} \mathrm{slug}$ & $45 \mathrm{~cm}$ slug & $60 \mathrm{~cm}$ slug \\
\hline \multirow{2}{*}{ Orchard } & North & 200 & 180 & 170 \\
\cline { 2 - 5 } & South & 190 & 190 & 180 \\
\hline \multirow{3}{*}{ Glider } & Center & 170 & 160 & 150 \\
\cline { 2 - 5 } & North & 180 & 170 & 160 \\
\cline { 2 - 5 } & South & 110 & 110 & 100 \\
\hline Mid-field & Center & 180 & 180 & 170 \\
\hline \multirow{3}{*}{ East } & Center & 160 & 150 & 140 \\
\cline { 2 - 5 } & North & 150 & 140 & 130 \\
\cline { 2 - 5 } & South & 170 & 170 & 160 \\
\hline
\end{tabular}


Table 4.13 Statistics for Table 4.12; Figure 4.17

\begin{tabular}{|l|c|c|c|c|}
\hline & East wells & Mid-field wells & Glider wells & $\begin{array}{c}\text { Orchard } \\
\text { wells }\end{array}$ \\
\hline Mean & 150 & 180 & 140 & 185 \\
\hline Std. Dev & 13.7 & 9.00 & 29.6 & 10.8 \\
\hline Std. Err & 1.87 & 2.12 & 4.03 & 1.95 \\
\hline $95 \%$ Conf & 3.76 & 4.47 & 8.10 & 3.99 \\
\hline $99 \%$ Conf & 5.00 & 6.15 & 10.7 & 5.37 \\
\hline Size & 54 & 18 & 54 & 31 \\
\hline Total & 8300 & 3260 & 7880 & 5760 \\
\hline Minimum & 130 & 170 & 100 & 170 \\
\hline Maximum & 180 & 200 & 190 & 210 \\
\hline
\end{tabular}

Table 4.14 Maximum, Mininum, Mean, and Standard Deviation for hydraulic conductivity ( $\mathrm{m} /$ day) of each slug size.

\begin{tabular}{|l|c|c|c|c|c|}
\hline & Number & Minimum & Maximum & Mean & $\begin{array}{c}\text { Std. } \\
\text { Dev. }\end{array}$ \\
\hline $30 \mathrm{~cm}$ slug tests K all wells & 9 & 110 & 200 & 170 & 25 \\
\hline $45 \mathrm{~cm}$ slug tests K all wells & 9 & 110 & 190 & 160 & 25 \\
\hline $60 \mathrm{~cm}$ slug tests K all wells & 9 & 100 & 180 & 150 & 24 \\
\hline
\end{tabular}

Table 4.15 Statistics for Table 4.14; Figure 4.18

\begin{tabular}{|l|c|c|c|}
\hline & $30 \mathrm{~cm}$ slug & $45 \mathrm{~cm}$ slug & $60 \mathrm{~cm}$ slug \\
\hline Mean & 160 & 150 & 150 \\
\hline Std. Dev & 25.2 & 24.9 & 24.3 \\
\hline Std. Err & 3.43 & 3.46 & 3.40 \\
\hline $95 \%$ Conf & 6.88 & 6.95 & 6.84 \\
\hline $99 \%$ Conf & 9.16 & 9.26 & 9.12 \\
\hline Size & 54 & 52 & 51 \\
\hline Total & 9150 & 8300 & 7750 \\
\hline Minimum & 110 & 100 & 100 \\
\hline Maximum & 210 & 200 & 190 \\
\hline
\end{tabular}




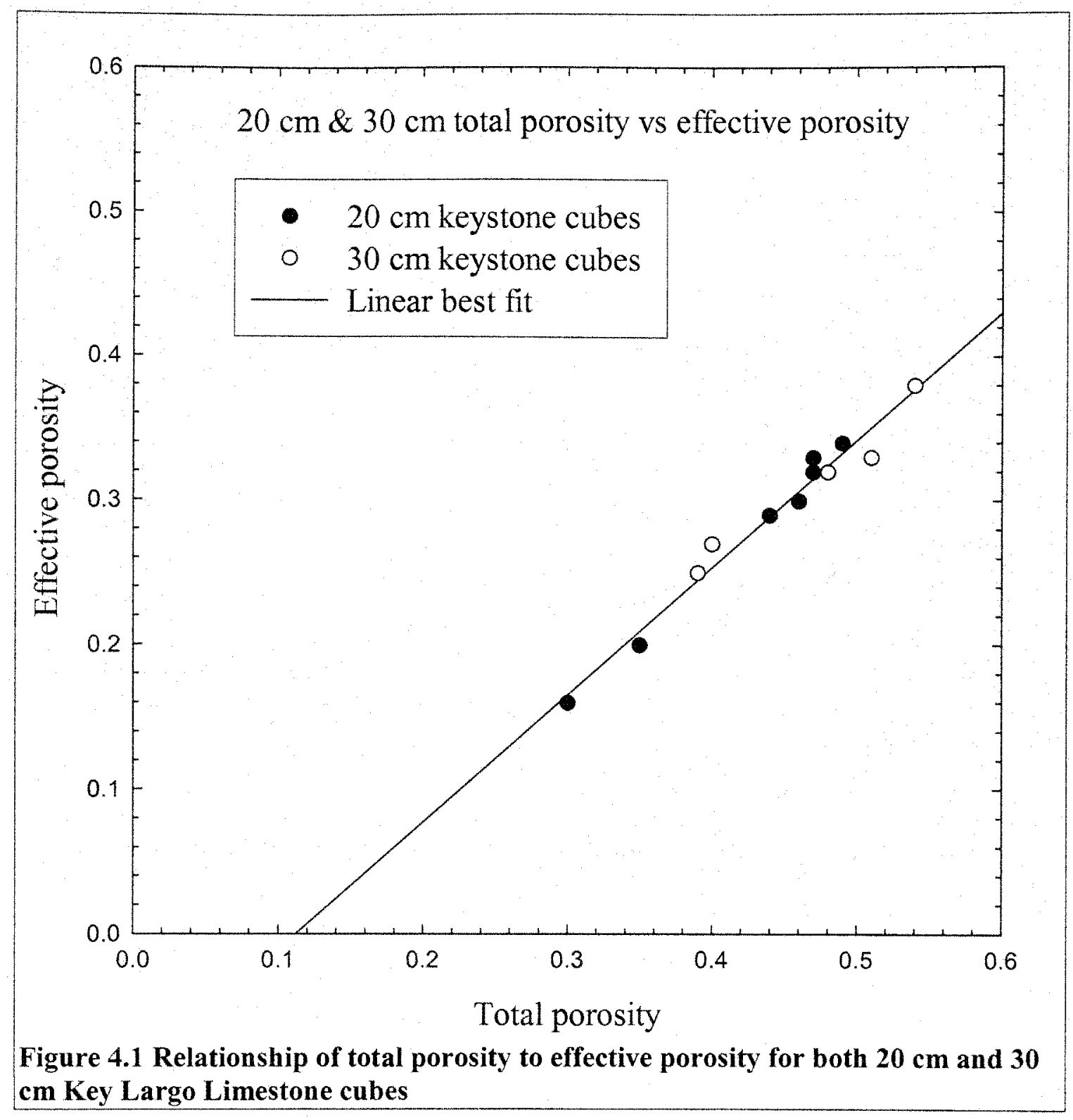




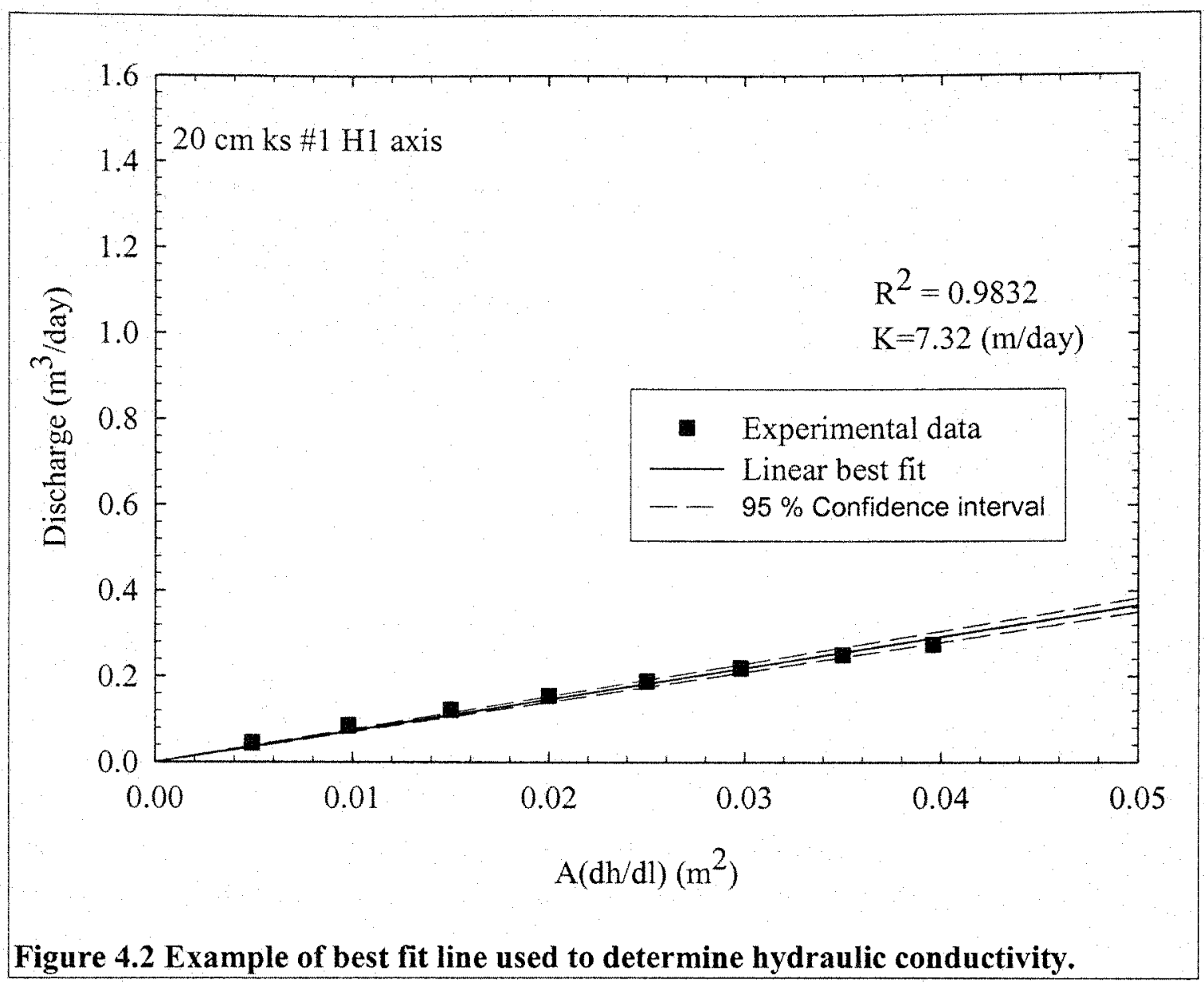




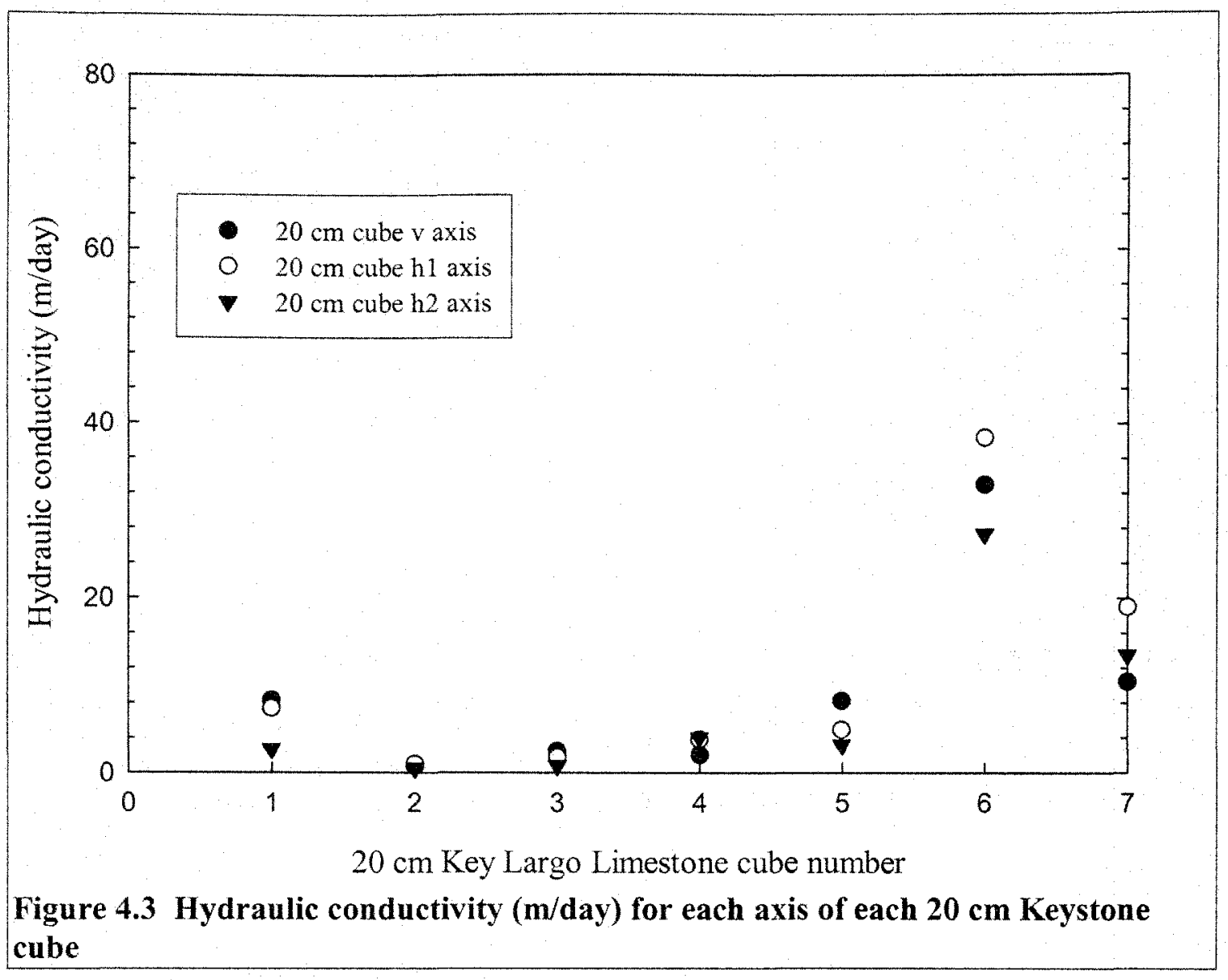




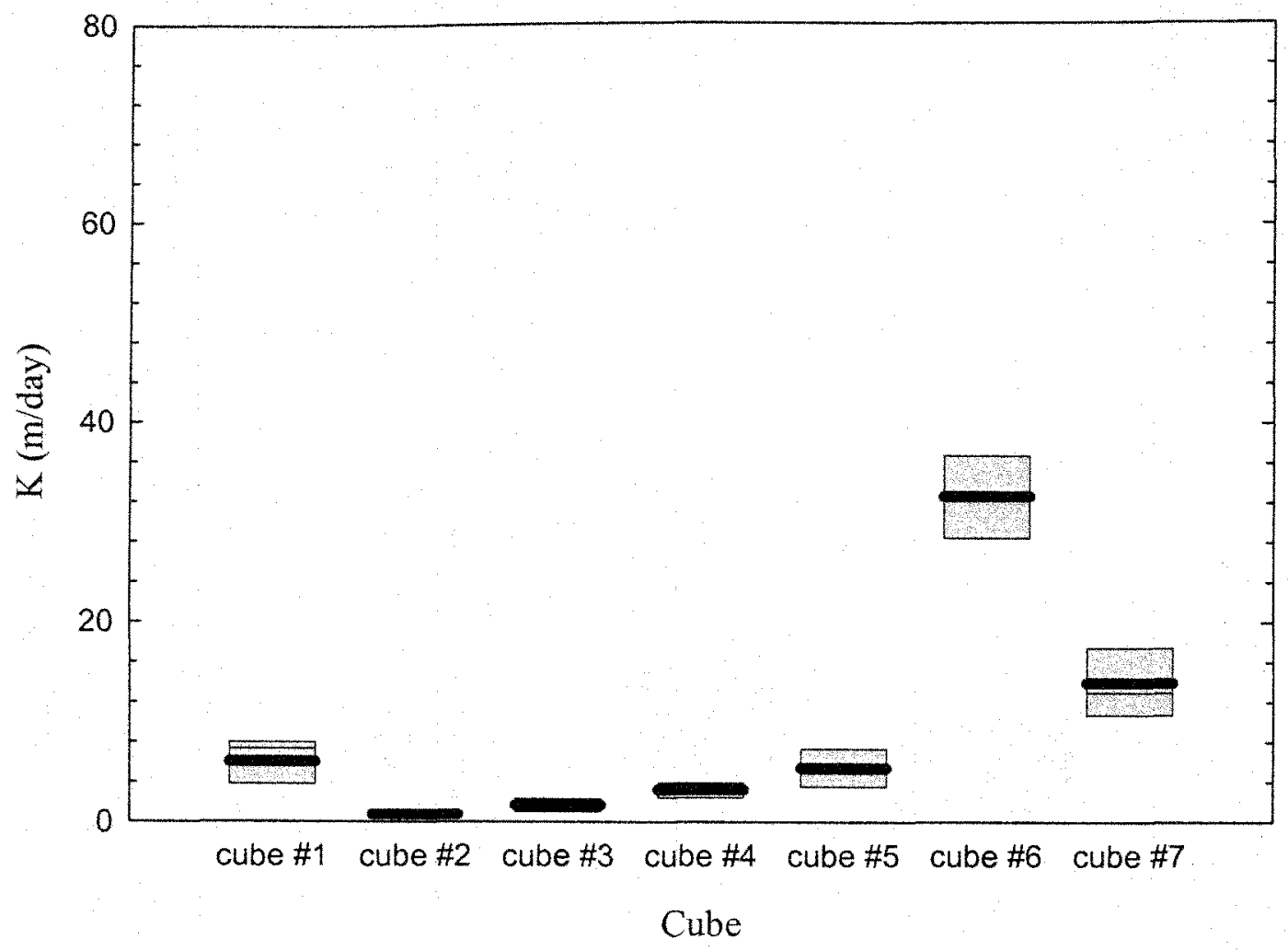

Figure 4.4 Diagram shows box and whisker plots of the average hydraulic conductivity value of each $20 \mathrm{~cm}$ Key Largo Limestone cube.

The box and whisker plot marks the mean hydraulic conductivity value with a bold horizontal line, the median is marked with a thin line. The box spans from the mid value of all values below the median (Q1) to the mid value of all values above the median (Q2) (Moore and McCabe, 2003). 


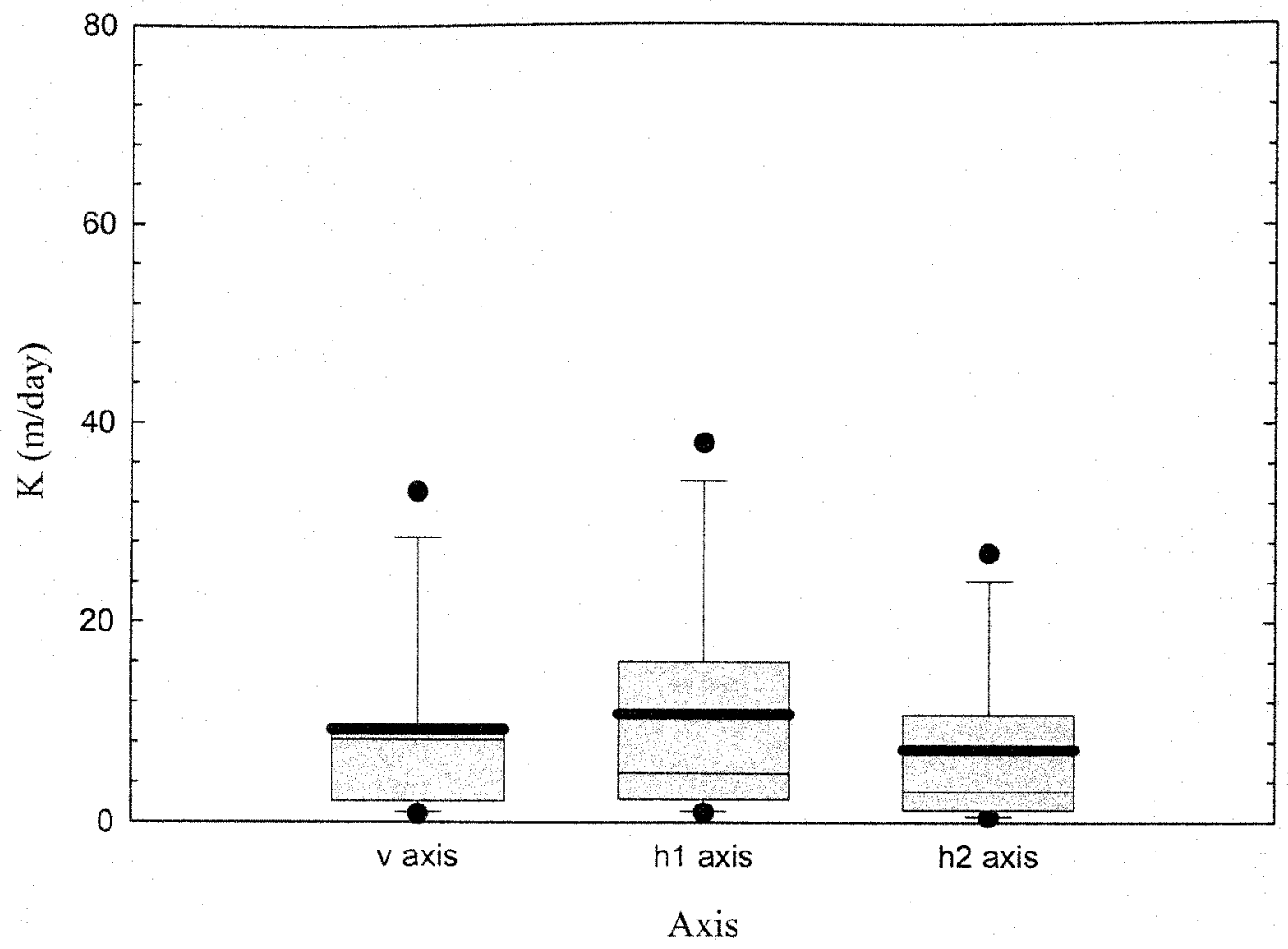

Figure 4.5 Diagram shows modified box and whisker plots of the average hydraulic conductivity value of each axis of the $20 \mathrm{~cm}$ Key Largo Limestone cubes.

There is no significant difference at the 0.05 level of the hydraulic conductivity between axes. The modified box and whisker plot marks the mean hydraulic conductivity value with a bold horizontal line, the median is marked with a thin line. The box spans from the mid value of all values below the median (Q1) to the mid value of all values above the median (Q2). Lines (whiskers) extend from the box out to the smallest and largest observations, excluding outliers. Hydraulic conductivity values for outliers are displayed as circles above or below the whiskers extending from the central box. Outliers are identified as having values above or below 1.5 times the difference between Q1 and Q3 (Moore and McCabe, 2003). 


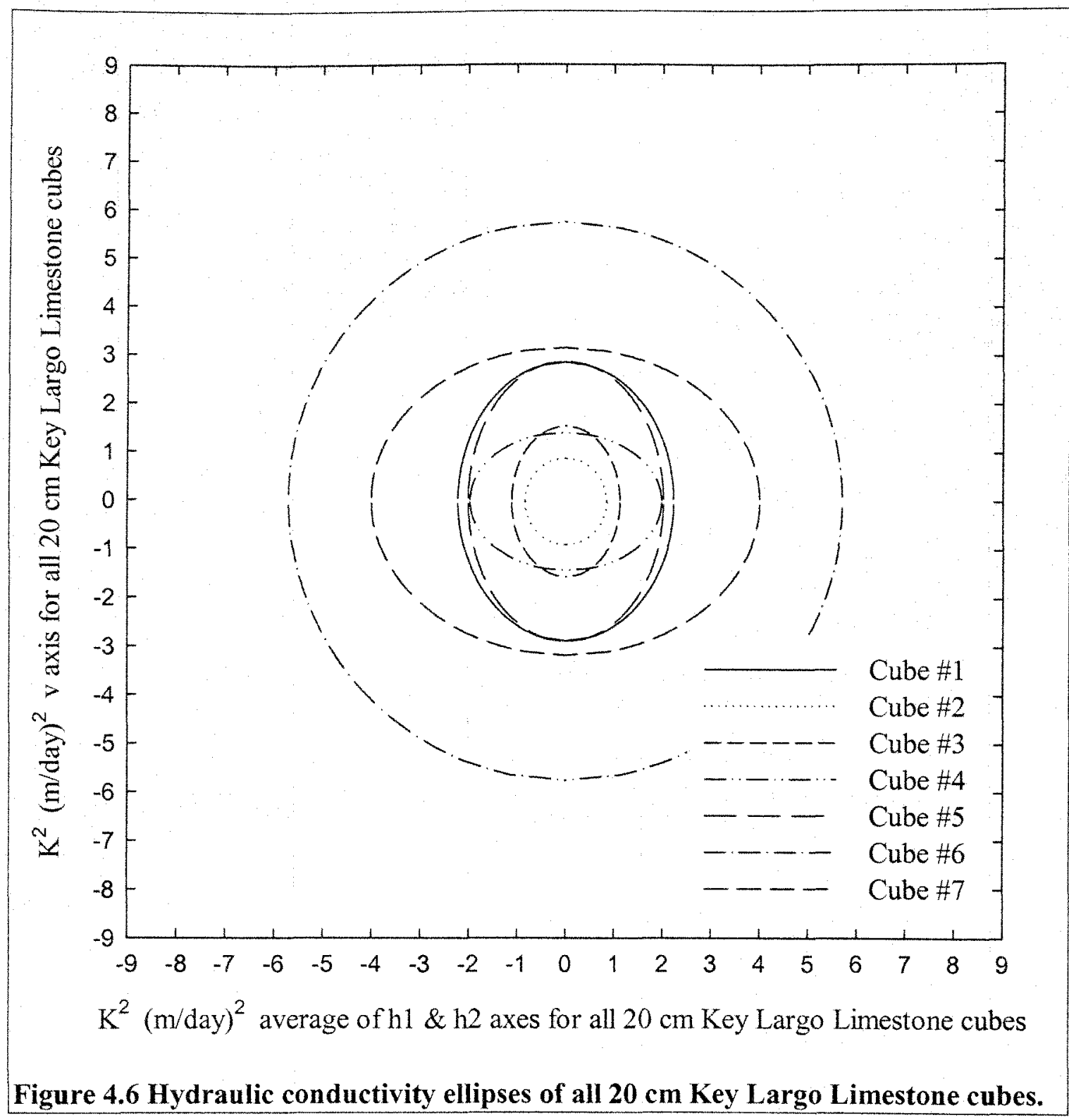




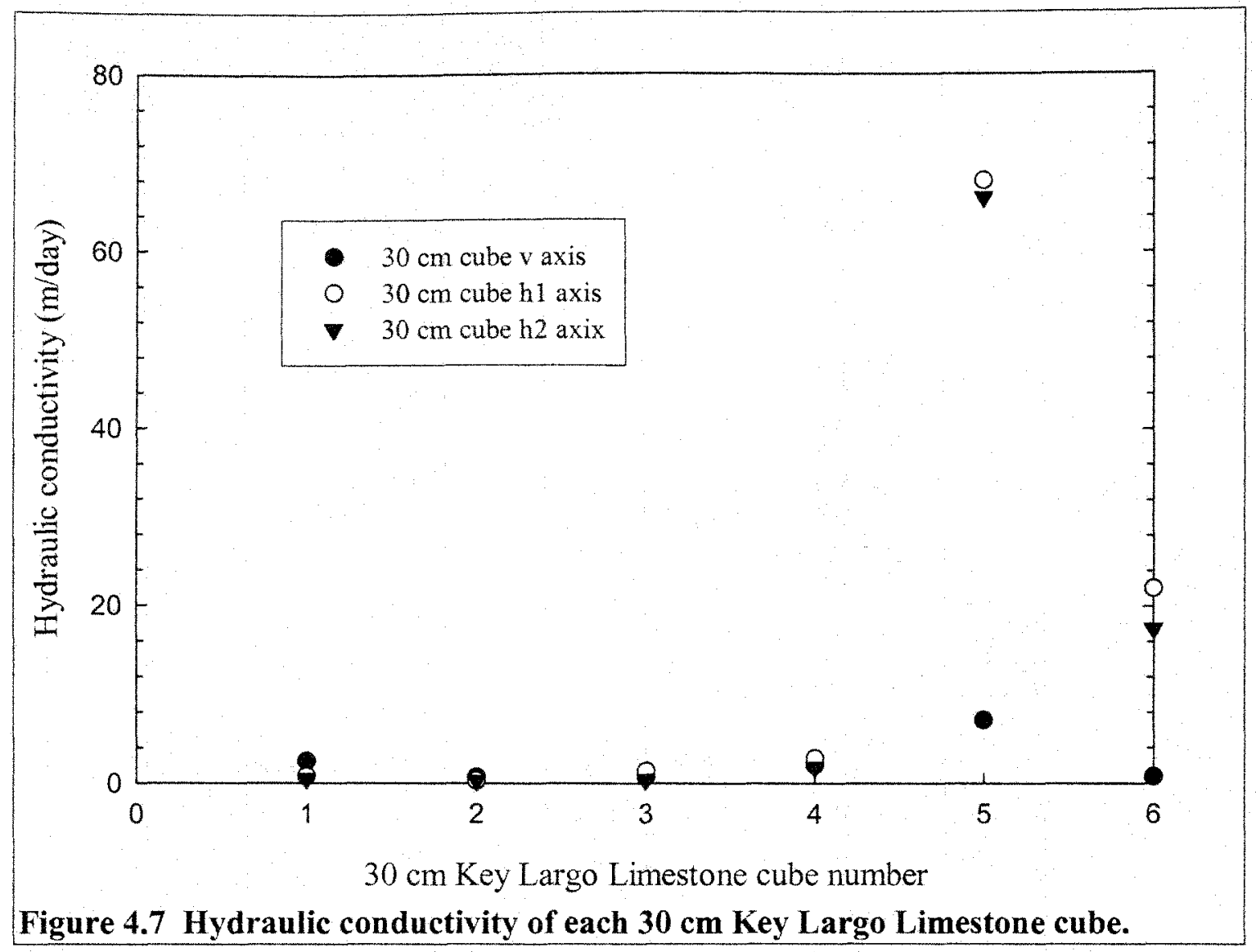




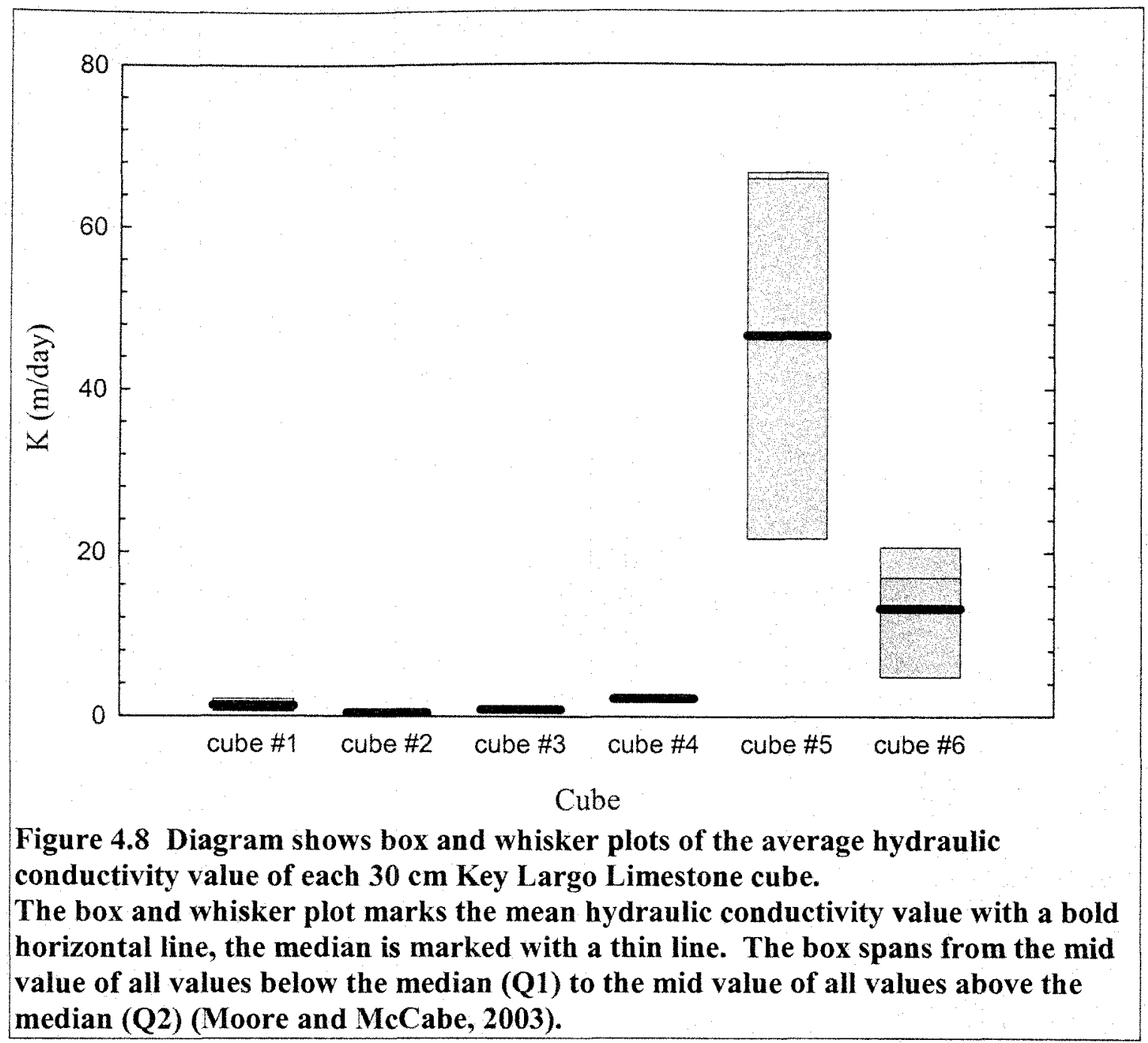




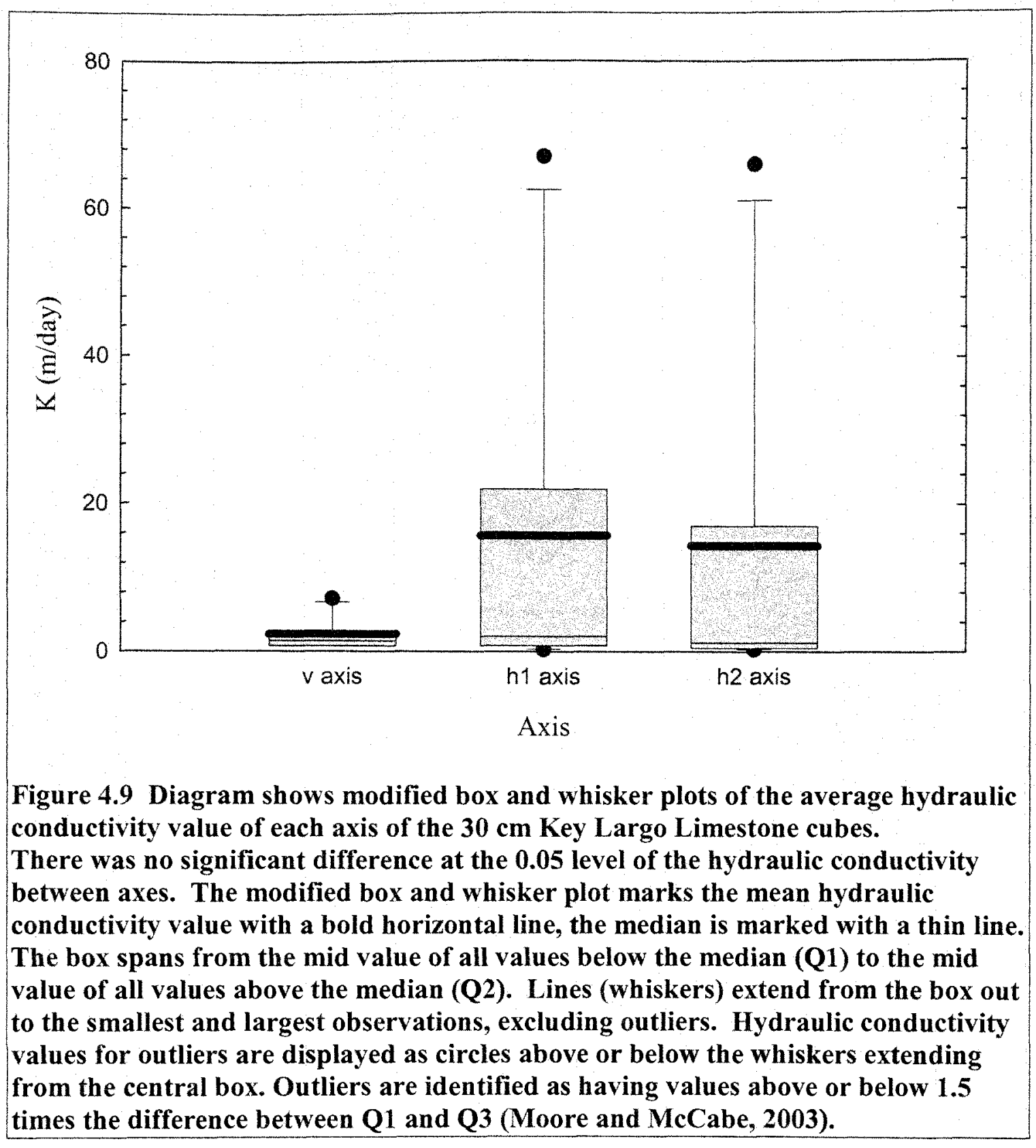




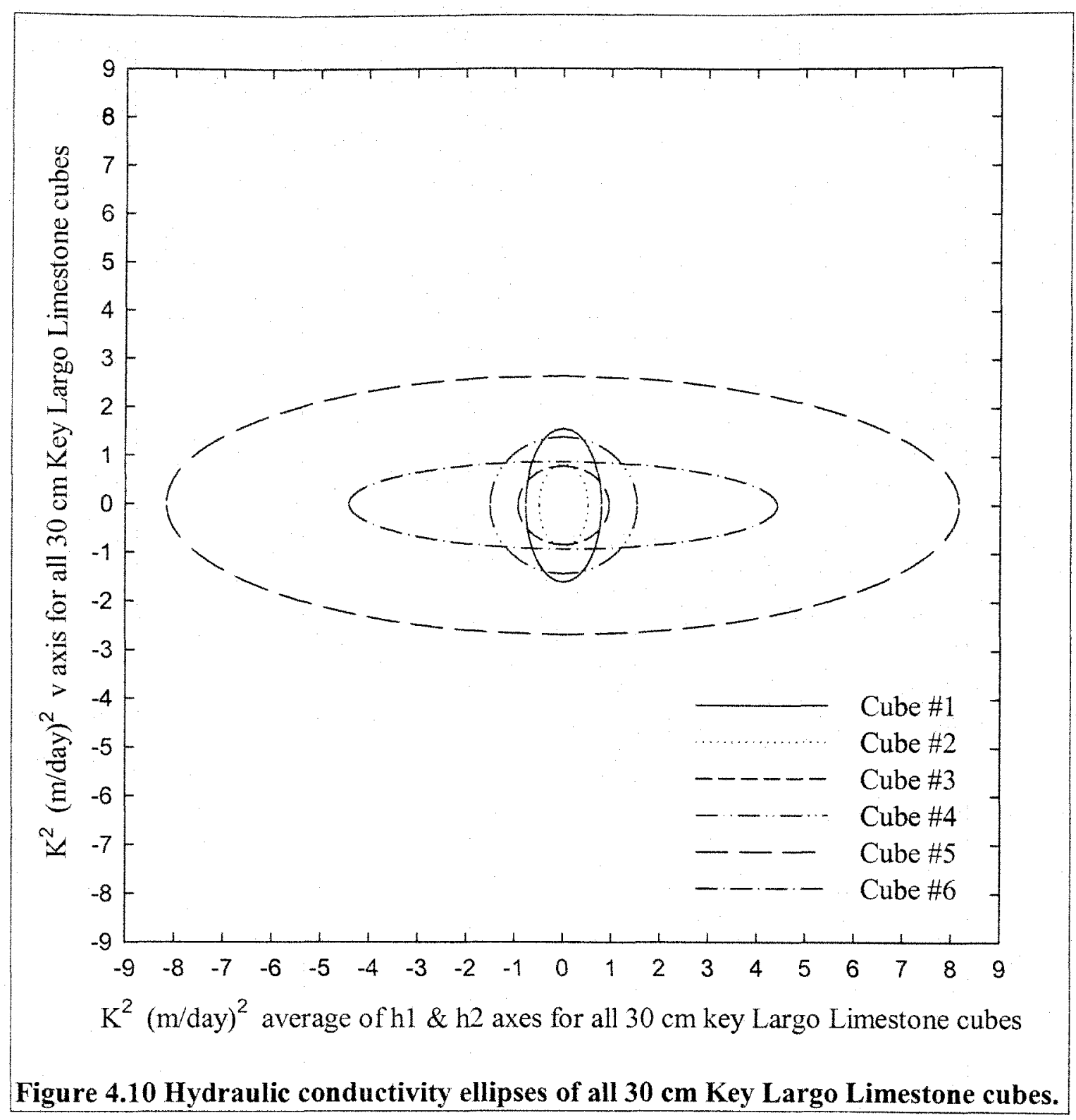




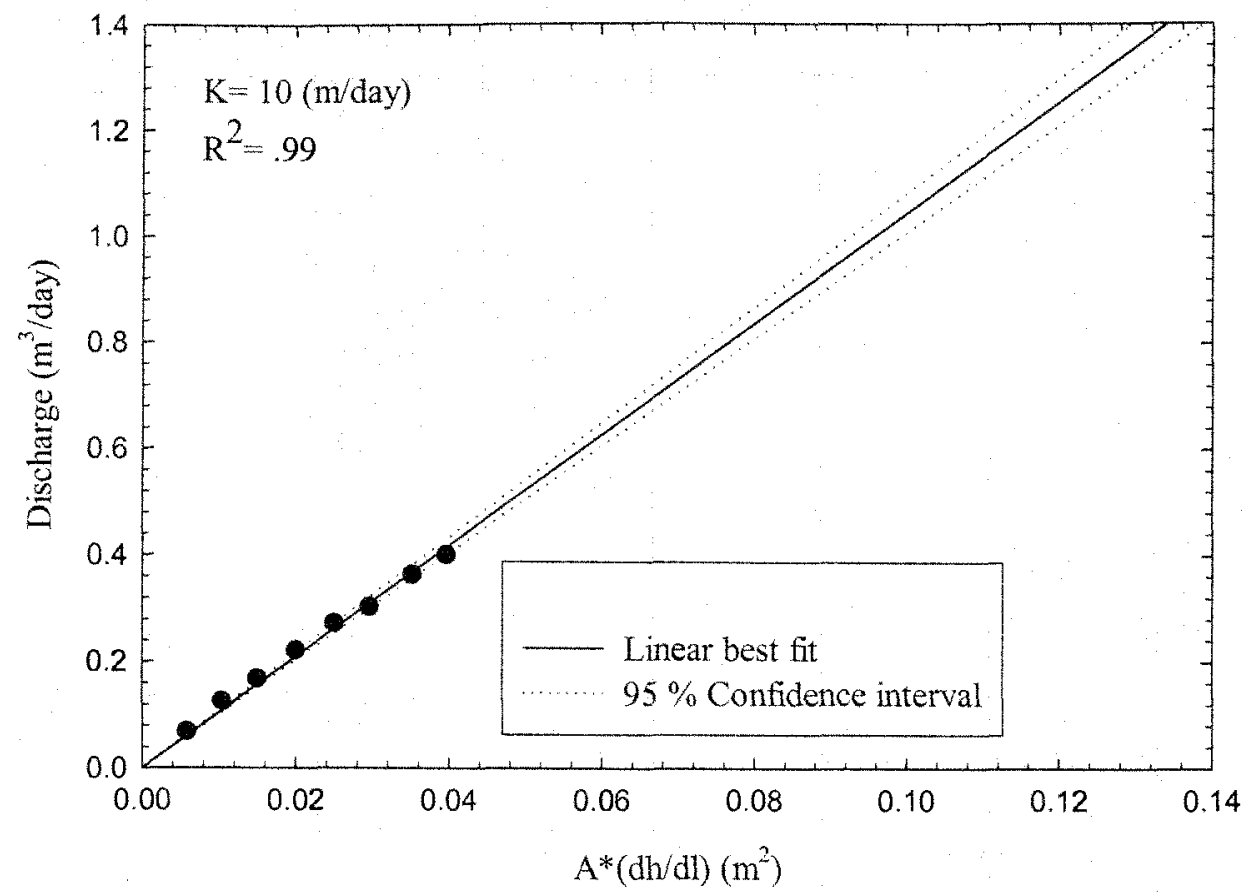

Figure 4.11 Hydraulic conductivity of high head test without high head values included.

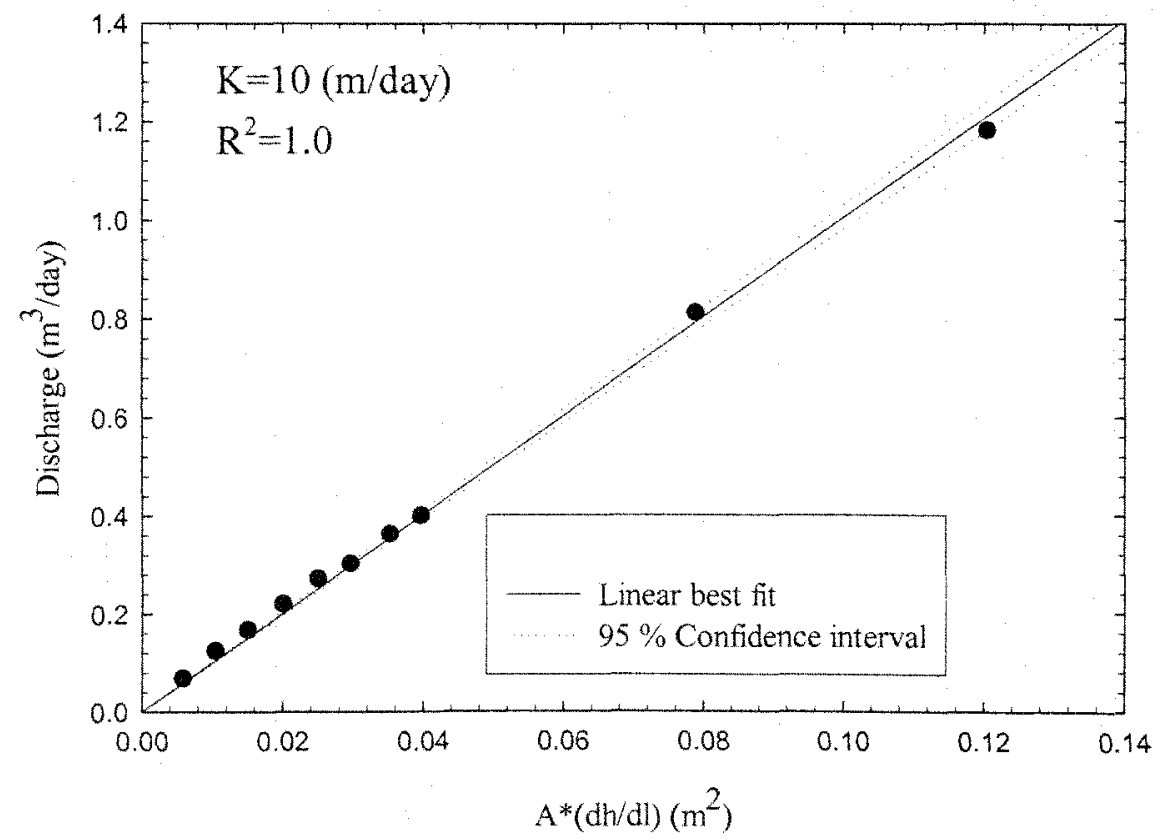

Figure 4.12 Hydraulic conductivity of high head test with high head values included. 


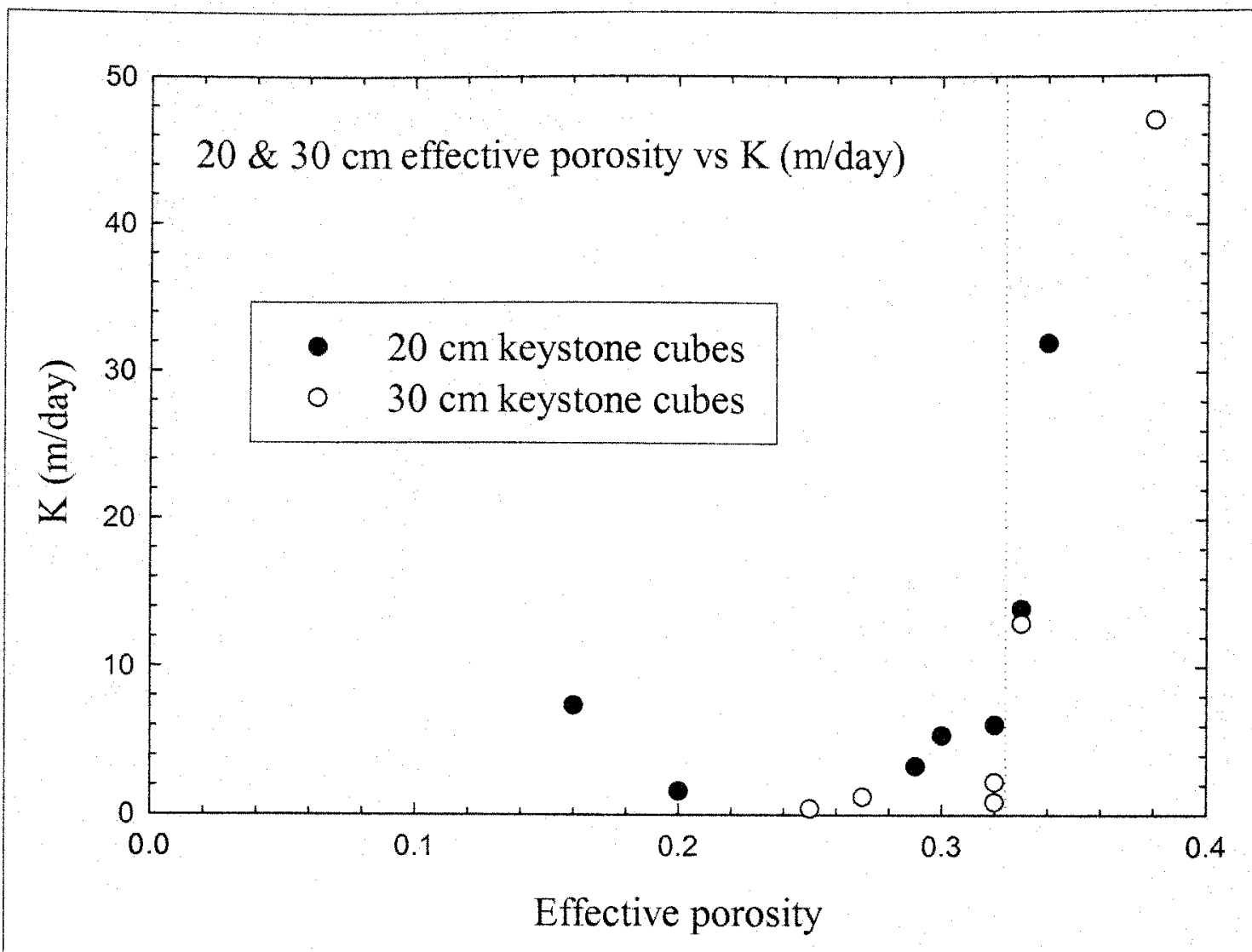

Figure 4.13 Effective porosity with hydraulic conductivity of cubes. Dotted line indicates a value of effective porosity beyond which hydraulic conductivity increases rapidly. 


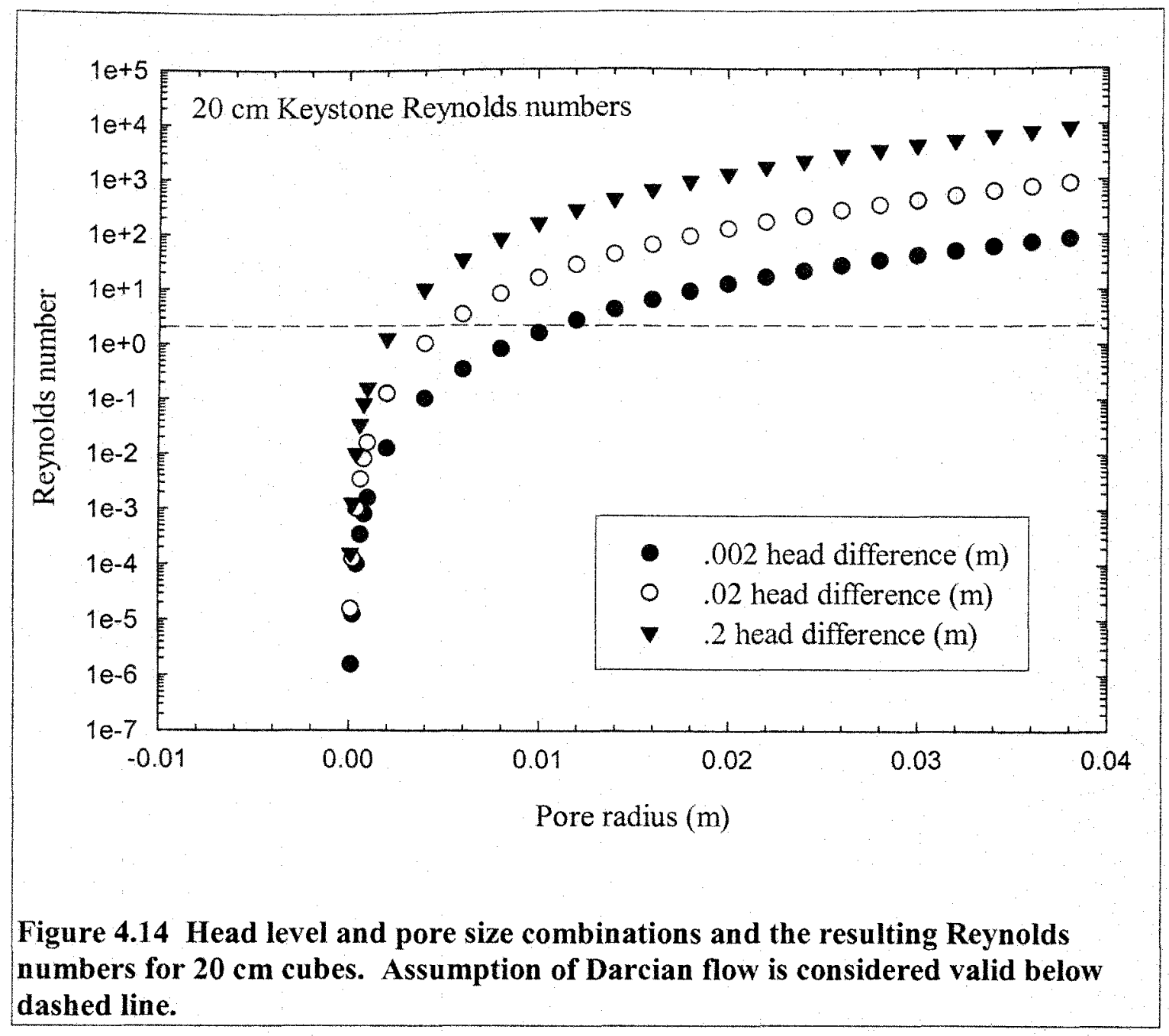




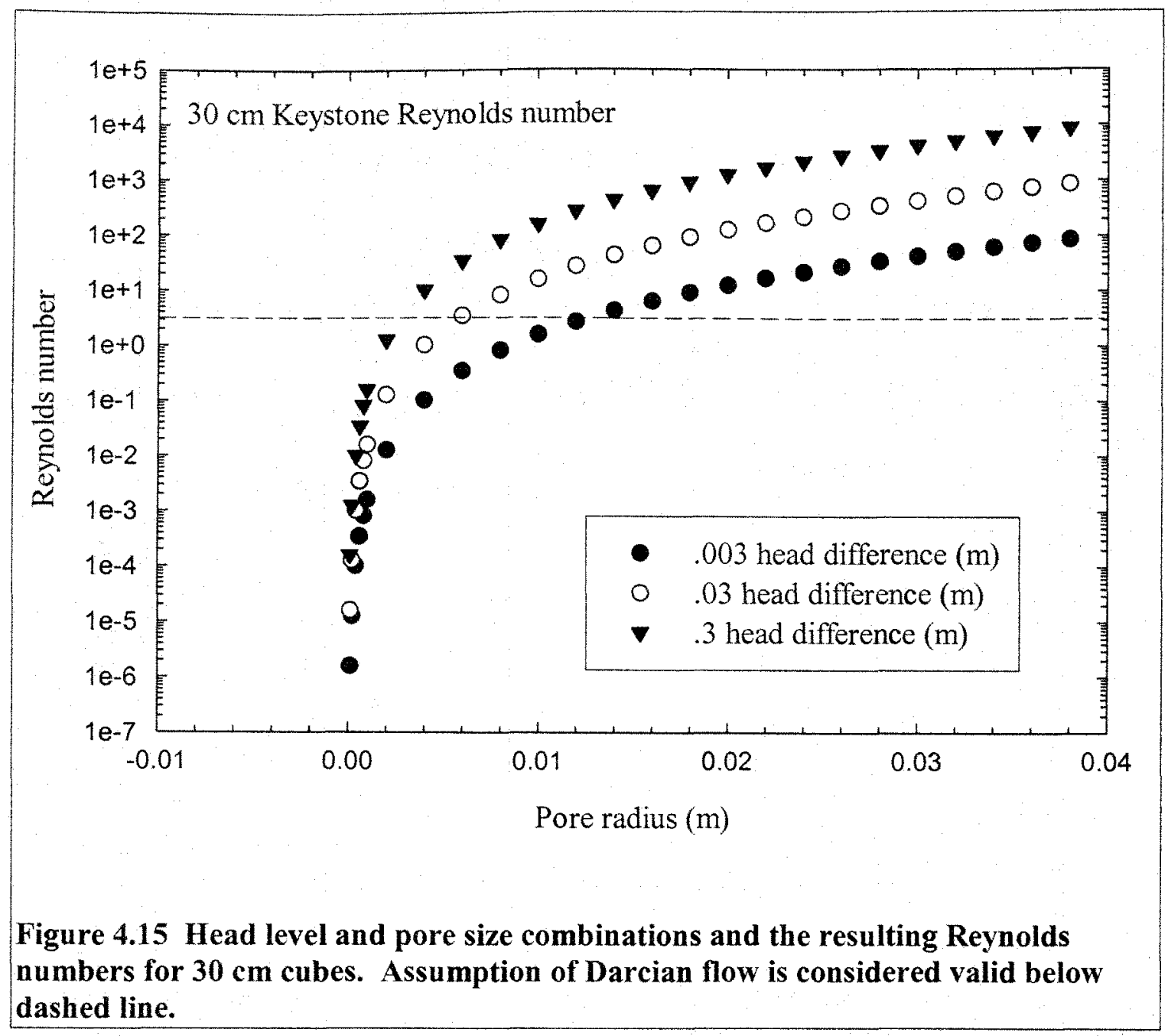




\section{APPLICABILITY OF DARCY'S LAW}

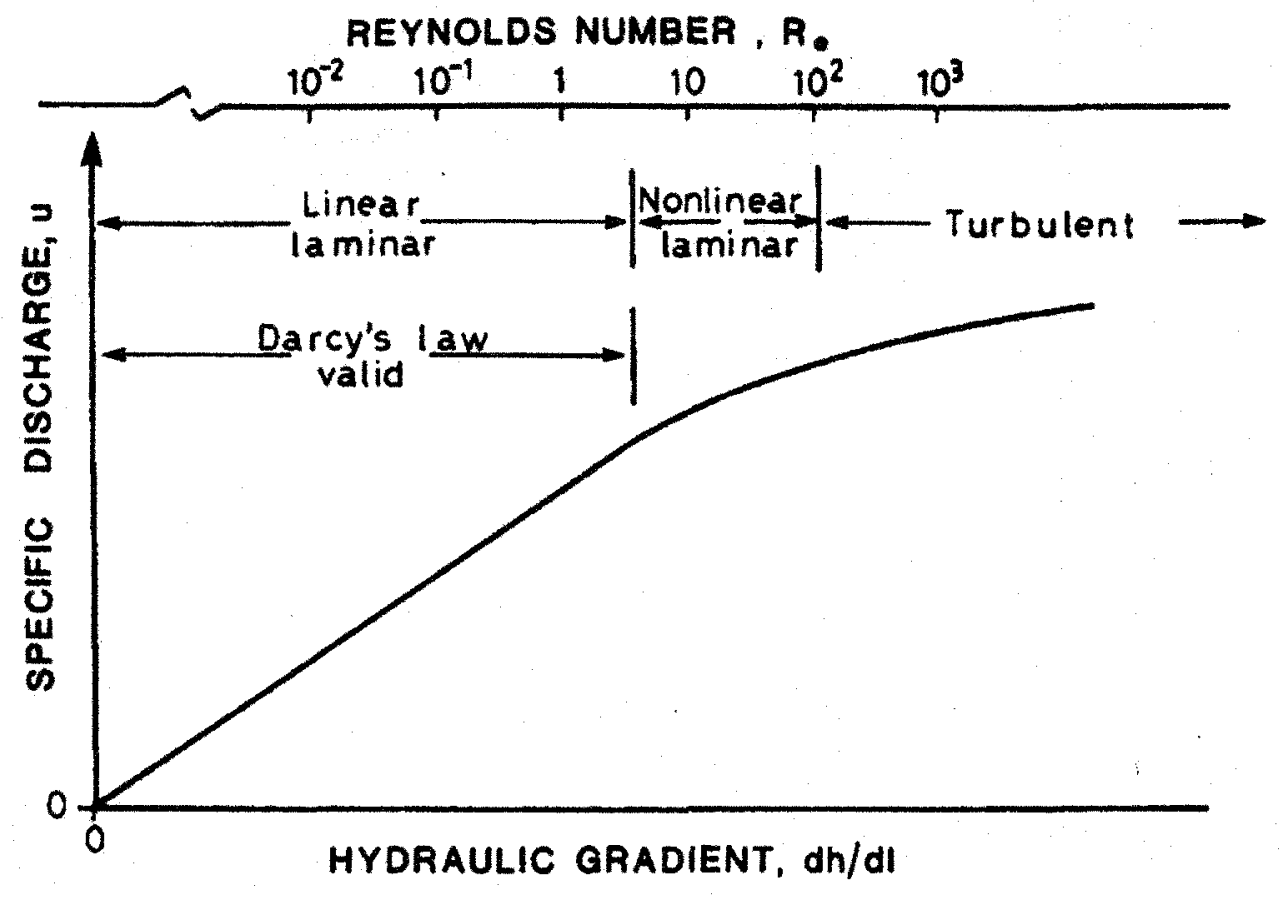

Figure 4.16 Range of validity of Darcy's law (Freeze and Cherry, 1979).

Most values derived from permeameter testing plotted in a straight line indicating that samples were tested in linear laminar flow, therefore, Darcy's law was valid. 


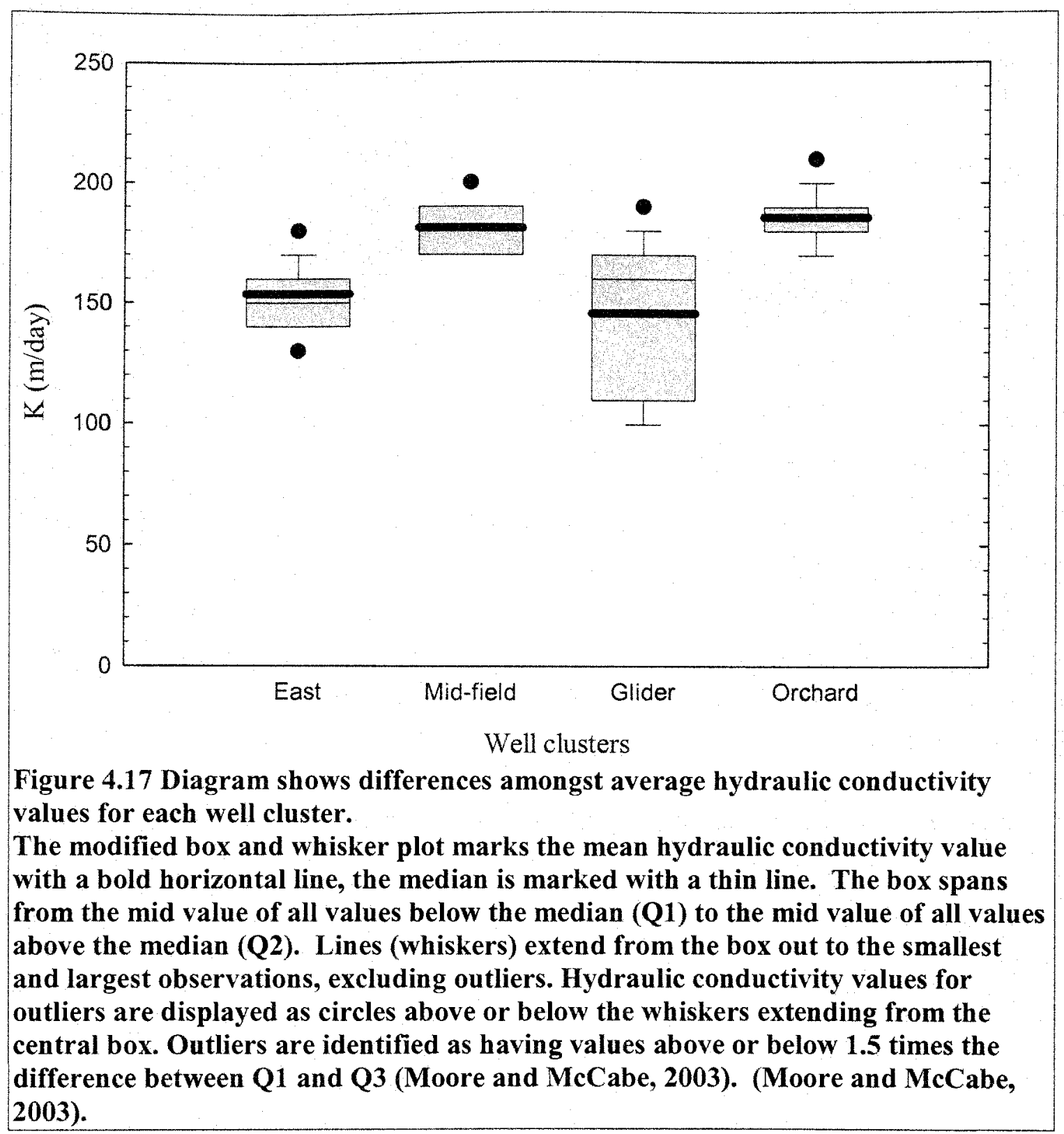




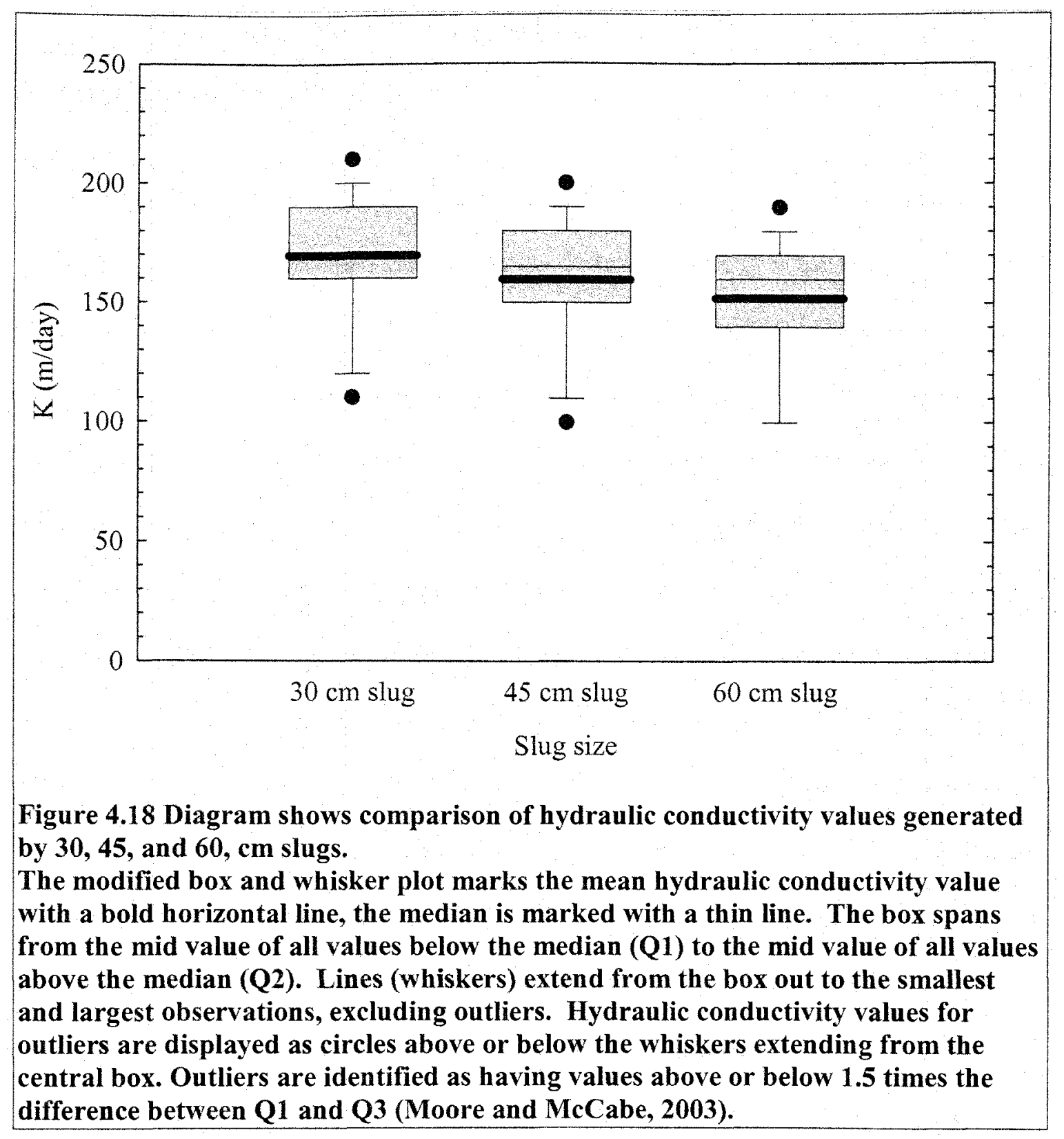




\section{CHAPTER 5}

\section{DISCUSSION}

\subsection{Total Porosity and Effective Porosity}

Total porosity is the ratio of the volume of voids in a rock or sediment to the total volume of the rock or sediment (Fetter, 2001). Effective porosity is the volume of voids available for fluid flow (Lohman et al., 1972). There is a difference between total porosity and effective porosity caused by connectivity of voids. The more connected the voids, the more total porosity can be utilized as effective porosity. Time must also be considered when determining the difference between total and effective porosity. Over a short time period less of the total porosity will be utilized as effective porosity than over a long time period. This is because time is required for flow to penetrate deeper into the matrix material and contact pore space that is not readily accessible to flow. Lacking sufficient time these pore spaces within the matrix are not accessed and therefore do not contribute to effective porosity. In my experiments the Key Largo Limestone cubes were flooded and vacuumed for 4 hours. The effective porosity value determined would therefore correspond to an event lasting hours, possibly days, but not to an event lasting over geological time. Porosity may be microscopic or macroscopic (Anselmetti et al, 1998). Microscopic porosity occurs at the crystal scale. Macroscopic or channel porosity is the porosity occurring as large fissures, conduits, and channels. These are voids occurring at an aquifer scale. Massive or formation porosity is aquifer scale porosity and is defined as the combined porosity from both interstitial pores (rock porosity) and fissures (channel porosity) (LaMoreaux and Wilson, 1984). 
The Biscayne Aquifer had two additional studies done at the core scale. Core plug testing determined total porosity to range from 6.6 percent to 46.6 percent with a mean of 24.7 percent (Cunningham et al., 2004) (Table 5.1; Figure 5.1). Whole core testing using helium resulted in total porosity values from 5.9 percent to 49.3 percent with a mean of 22.3 percent (Cunningham et al., 2004) (Table 5.1; Figure 5.1). Another study on similar cores determined total porosity to be 35 percent (Genereux, personal communication). This study determined mean total porosity from $20 \mathrm{~cm}$ cubes of Key Largo Limestone was 42 percent (Figure 5.2); while $30 \mathrm{~cm}$ cubes from the same formation had mean total porosity values of 46 percent (Figure 5.2). The higher average total porosity values obtained in this study may be due to the Key Largo Limestone cubes being larger than cores tested by others or due to differences in the formations tested. Kevin Cunningham tested Fort Thompson Formation, while D. Genereux tested Miami Oolite.

This study determined mean effective porosity from $20 \mathrm{~cm}$ cubes of Key Largo Limestone was 28 percent (Figure 5.3); while $30 \mathrm{~cm}$ cubes from the same formation had mean effective porosity values of 31 percent (Figure 5.3). Effective porosity is often equated with specific yield in unconfined aquifers with solutional porosity (Merritt, 1997). Specific yield is the portion of water in an aquifer that drains due to gravity. Specific yields ranging from 0.14 to 0.33 were determined for the Biscayne Aquifer based upon correlations with rainfall intensity and water table rise (Merritt, 1997). These values were similar to the effective porosity values found in this study.

The surficial Biscayne Aquifer of Pleistocene age was compared to other aquifers world-wide. Aquifers in the Bahamas and the Mediterranean were similar to the 
Biscayne Aquifer in age (Pleistocene) and were unconfined. Other karst aquifers in Florida and Texas were confined and older than the Pleistocene.

Sediments of the Avon Park Formation of the Floridan Aquifer apparently were buried without being subjected to a substantial influx of freshwater (Ward et al., 2003). Intergranular and moldic porosity of 30 to 40 percent is still preserved in many grainstones and grain-dominated packstones. Additionally, matrix porosity is equally high in mud-dominated packstone and wackestone. Matrix permeability is high only in the grainy limestones (Budd, 2001). An effective porosity of 42 percent was obtained by model calibration in the Tampa area of the Floridan Aquifer (Chen et al, 1999). These values of total porosity are very similar to the values of 42 and 46 percent for $20 \mathrm{~cm}$ and $30 \mathrm{~cm}$ cubes tested in this study.

In the Edwards Aquifer, effective aquifer thickness and effective porosity can be highly variable and is poorly defined throughout most of the aquifer. Estimates were computed within known or inferred thicknesses of 100 to $250 \mathrm{~m}$ and had porosities between 15 to 35 percent, respectively (Kuniansky et al., 2001). In a karst system, such as the Edwards Aquifer, the entire thickness of the aquifer may not be the permeable or transmissive zone. Additionally, the rock matrix porosity may not be representative of the effective porosity. Porosities of less than 1 to 5 percent for parts of the Edwards Aquifer have been reported (Sieh, 1975; Small and Maclay 1982; Hovorka et al, 1993). The Biscayne Aquifer had higher values of both total and effective porosity compared to the Edwards Aquifer.

Total porosity values were determined from microscopic scales to bench scales in Pleistocene aquifers in other studies. Microscopic total porosity on samples collected 
from the Bahamas was determined to be 24 percent (Anselmetti, 1998). This value is much smaller than the values of 42 and 46 percent for 20 and $30 \mathrm{~cm}$ cubes respectively from the Biscayne Aquifer. The island of Mallorca Spain, in the Mediterranean Sea showed total porosity of 3 to 57 percent with a mean value of 34 percent. These values were determined from $5 \mathrm{~cm}$ core samples (Price and Herman, 1991).

Percolation threshold is defined as the porosity below which the sample allows no flow. Although considerable porosity may be present, effective porosity is not present. The minimal fraction of pores that must be connected for a sample-spanning flow path to be formed are not present (Kaponen et al., 1996; Friedman and Seaton, 1998). Below the percolation threshold, all pores that connect to a boundary are effectively isolated from the interior of the network and percolation does not occur. Flow through porous media occurs through interconnected pores. Pores not connected to the main void space do not contribute to flow. Pores that create vugs that do not pass from end to end of the medium are called dead-end pores. Dead-end pores contribute minimally to flow because fluid must pass through matrix material to flow from one dead-end pore to another (Kaponen et al., 1996; Sukop et al., 2002). Increasing the porosity causes the porosity to reach the percolation threshold and the network percolates (Sukop et al., 2002). Flow is controlled by the critical pore (Ambergaokar et al., 1971). The pore that completes the percolation cluster is the critical pore, before this value is reached vugs are separated by matrix material (Friedman and Seaton, 1998). The critical pore size according to critical path analysis is determined as follows, the percolating cluster of pores is formed when the cumulative fraction of pores larger that the critical pore size is equal to the percolation threshold of the network (Friedman and Seaton, 1998). The clusters that form in 
prefractal media appear to be better models of clusters that exist in many natural pore spaces because they have large pore bodies connected by small pore necks (Sukop et al., 2002). This seems to apply to the karstic formations of the Biscayne Aquifer where the porosity is caused by dissolution. Further increases in porosity cause more of the pore space to be connected (Sukop et al., 2002). My data indicates that once effective porosity exceeds approximately $33 \%$ there is a large increase in hydraulic conductivity (Figure 4.13). This may be caused by the matrix material between dead ended pores becoming connected thus allowing these pores to contribute to flow.

\subsection{Hydraulic conductivity}

Henry Darcy in 1856 (Darcy, 1856) found that the rate of water flow through a bed of a "given nature" is proportional to the difference of the height of the water between the two ends of the filter bed. It is also inversely proportional to the length of the flow path. Darcy determined that the quantity of flow is proportional to a coefficient, $\mathrm{K}$, which is dependent upon the nature of the porous medium and the fluid (Fetter, 2001). This coefficient, $\mathrm{K}$, is hydraulic conductivity. Hydraulic conductivity is measured in units of length per time.

Bench scale and field scale tests of hydraulic conductivity determined in this study ranged from $0.51 \mathrm{~m} /$ day obtained from a $20 \mathrm{~cm}$ cube, to $200 \mathrm{~m} /$ day obtained by a slug test on a well (Figure 5.4, Figure 5.5, Figure 5.6). These values of hydraulic conductivity are low compared to values obtained from field studies conducted on larger scales. For instance, water exchange studies between canals and surrounding aquifer and wetlands gave hydraulic conductivity values of $7.6 \times 10^{3} \mathrm{~m} /$ day (Bolster et al, 2001). Pumping tests 
gave values of hydraulic conductivity between $10^{2}$ and $10^{4} \mathrm{~m} /$ day (Fish and Stewart, 1991) (Table 5.2).

During the slug tests in wells, large slugs caused smaller hydraulic conductivity values compared to the smaller slugs. This can be explained by turbulence. Large slugs caused a larger change in head level. This large change probably caused the velocity of the ground water coming into the well to exceed Darcian flow. Energy was lost to the turbulence resulting in lower hydraulic conductivity values (Figure 4.18). A series of smaller slugs would give improved results. The sensitivity of the cr23-x data logger and it's ability to measure small changes in head combined with and it's ability to take head level measurements in 1/50 second intervals make reliable slug tests possible.

Bench scale testing in this study was conducted in a novel fashion. The permeameter designed and constructed allowed testing the hydraulic conductivity of each axis of cubes 20 and $30 \mathrm{~cm}$ on a side. These samples are considerably larger than thin sections, plugs or whole cores. Also, the cubes were cut from a large block allowing 100 percent recovery of material used for samples. The ability to test both vertical and horizontal axes for hydraulic conductivity allowed testing for anisotropy. (Figure 4.6, Figure 4.10) Hydraulic conductivity values are a component for modeling groundwater flow. Various agencies in south Florida have an interest in using groundwater models to predict flow in the Biscayne Aquifer. Hydraulic conductivity values in use in the South Florida Water Management District Model for infiltration rates range from 2 to 30 ( $\mathrm{m} /$ day). Aquifer transmissivities in the area of the Homestead General Airport range from 162 to greater than $209 \mathrm{~m}^{2} /$ day (SFWMD, 1999). The USGS simulation of ground water discharge to Biscayne Bay, Southeastern Florida uses $9,000 \mathrm{~m} /$ day as the value for 
horizontal hydraulic conductivity for most of the model. This value is assigned to Miami Oolite, Fort Thompson Formation, and permeable zones of the Tamiami Formation. The northeastern and southern areas have hydraulic conductivity values of $3 \mathrm{~m} /$ day assigned to simulate upper layers of peat and marl. The central portion of the model has a hydraulic conductivity value of $1,500 \mathrm{~m} /$ day assigned (Langevin, 2001). Hydraulic conductivity values for Key Largo Limestone cubes would be of little value to these models. The cubes are of a negligible scale compared to the scale of these models. Also, the models are in different formations. Hydraulic conductivity values from the slug tests would be of use for these models as they are of comparable scale and in the same formation.

The importance of karst aquifers for world-wide water supplies has led to studies of other karst aquifers. The Floridan aquifer system is one of the most productive aquifers in the world (Broska and Barnette, 1999). Estimated horizontal conductivity values of the upper Floridan Aquifer range from $1 \times 10^{-4} \mathrm{~m} /$ day to $9 \mathrm{~m} /$ day, with a median value of $6 \times 10^{-3} \mathrm{~m} /$ day (Hayes et al, 1983). Hydraulic conductivity values of $220 \mathrm{~m} /$ day for the deepest part of the upper aquifer have been calculated (Hayes et a1,1983). These values are low compared to the Biscayne Aquifer with hydraulic conductivity values ranging from $5 \times 10^{-1} \mathrm{~m} /$ day to $10^{4} \mathrm{~m} /$ day (Table 5.2 ).

The Edwards aquifer in west central Texas has a thickness of up to $165 \mathrm{~m}$, making it thicker than the Biscayne Aquifer, which has a maximum depth of $70 \mathrm{~m}$. Except for areas of significant karst-induced permeability, the average hydraulic conductivity of the Edwards-Trinity Aquifer is about $3 \mathrm{~m} /$ day, judging from transmissivity and saturated thickness distributions (Barker and Ardis, 1996). Calibration of a steady state model 
using trial and error resulted in 10 zones with hydraulic conductivity ranging from 0.3 to $305 \mathrm{~m} / \mathrm{d}$. Hydraulic conductivities were generally low $(0.3$ to $1.3 \mathrm{~m} / \mathrm{d})$ in the outcrop area where the hydraulic gradient is steep. Hydraulic conductivities were generally high adjacent to major springs because of the confluence of conduits and increased dissolution in this zone (Barker and Ardis, 1996). In the Edwards Plateau hydraulic conductivity ranges from 0.0009 to $221 \mathrm{~m} /$ day, with a median value of $0.7 \mathrm{~m} /$ day. In the Balcones Fault Zone hydraulic conductivity ranges from 0.2 to $2,400 \mathrm{~m} /$ day, with a median value of $36 \mathrm{~m} /$ day (Boghici, 2002) (Table 5.2).

Hydraulic conductivity testing was done on two additional Pleistocene aquifers in other studies. Core scale tests performed on samples from the Lucayan Aquifer in the Bahamas determined hydraulic conductivity to have an average value of $10^{-2} \mathrm{~m} /$ day (Whitaker and Smart, 2000). Slug tests performed in the Lucayan Aquifer determined hydraulic conductivity to be $10^{2} \mathrm{~m} /$ day (Whitaker and Smart, 2000). Pumping tests in the Lucayan Aquifer determined hydraulic conductivity to be $10^{3} \mathrm{~m} /$ day (Whitaker and Smart, 2000). This range of hydraulic conductivities is smaller than the range of hydraulic conductivities for the Biscayne Aquifer, which has a low of $0.51 \mathrm{~m} /$ day to a high of $10^{4} \mathrm{~m} /$ day.

The island of Mallorca Spain, one of the Balearic Islands, in the Mediterranean Sea showed hydraulic conductivity values of $100 \mathrm{~m} /$ day to $2000 \mathrm{~m} /$ day on Pleistocene limestone. These values were determined from $5 \mathrm{~cm}$ long cores (Price and Herman, 1991)(Table 5.2). This range of hydraulic conductivity values is similar to the range of hydraulic conductivity values for the Biscayne Aquifer obtained from the cubes and slug 
test scale even though the testing for the Mallorca limestone was done on smaller core samples.

\subsection{Effect of Scaling on Hydraulic Conductivity}

Hydraulic conductivity values within the Biscayne Aquifer were measured over increasing scales. The smallest scale was a $20 \mathrm{~cm}$ cube, scales increased through $30 \mathrm{~cm}$ cubes, $1.5 \mathrm{~m}$ slug tests, to aquifer scale pump tests. Hydraulic conductivity was shown to increase with increasing scale (Figure 5.4). Geological discontinuities exist at all scales: intragranular cracks not longer than a few microns; microfractures of a few millimeters or centimeters; fractures of meter or decameter length; faults of a few hectometers; kilometers or tens of kilometers; big fault zones extending over several hundreds of kilometers; and cave systems with length of tens of kilometers (Kiraly, 2003). A study done in the Jura Mountains in Switzerland on a karst aquifer showed the effect of scaling on hydraulic conductivity. Pumping tests conducted in 300 to $400 \mathrm{~m}$ deep boreholes in fractured rock mass had a low hydraulic conductivity, $8.6 \times 10^{-1}$ to $8.6 \times 10^{-2} \mathrm{~m} / \mathrm{day}$. In these karstic aquifers, besides the common fracture network with "meshes" of a few meters, there must be a high-permeability channel network with wide, kilometer intervals, which is well connected to a discharge area, a karstic spring. Regional numerical models showed that at a basin-wide scale the overall hydraulic conductivity must be 2000 to 5000 times higher than the "local" conductivity values measured in the boreholes. This important scale effect is due to the very high hydraulic conductivity of the widely spaced karst channel network. As most of the boreholes are located between the karst channels, the locally measured hydraulic conductivity values don't give information on the existence of this scale effect (Kiraly, 2003). 
A scaling effect study of hydraulic conductivity as found in this study compared well with those obtained for the Lucayan Aquifer in the Bahamas (Figure 5.7). Studies in both aquifers included bench scale testing, slug testing, and pump testing. Additionally packer tests were done in the Lucayan Aquifer. Bench scale testing in the Lucayan Aquifer was done on cores, while bench scale testing in the Biscayne Aquifer was done on $20 \mathrm{~cm}$ and $30 \mathrm{~cm}$ cubes. Pumping test values for the Biscayne Aquifer included on Figure 5.3 were obtained from Fish and Stewart (1991). In all the above cases the ranges from the Lucayan Aquifer were larger than ranges from the Biscayne Aquifer. This is most likely due to a higher number of samples analyzed at each scale in the Lucayan Aquifer study.

Hydraulic conductivity values from the Biscayne and Lucayan Aquifers are near the high end of the range of expected hydraulic conductivity values of karst aquifers as reported by Kiraly (1975) (Figure 5.8). The highest hydraulic conductivity values for these two aquifers are also higher than the highest values reported for the Floridan, Edwards and Mallorcan aquifers (Table 5.2). The similarity in hydraulic conductivity values of the Biscayne and Lucayan Aquifers is not surprising given that they were formed during similar geologic time and conditions.

\subsection{Types of flow}

Darcian flow is a type of fluid movement where the stream lines that water molecules follow are smooth lines. It occurs in slow moving fluids under a low hydraulic gradient where viscosity is the dominant factor governing fluid flow (Figure 4.16) (Fetter, 2001). An implication of accepting the Darcian approach is that the rock is considered as a 
continuum of voids and solid matter for which certain generalized macroscopic parameters, such as hydraulic conductivity, can be defined. These parameters represent and describe macroscopic behavior. In karst this means that the fractured rock penetrated by solution conduits would be replaced by a conceptual representative continuum for which it is assumed possible to determine hydrologically meaningful macroscopic parameters (Ford and Williams, 1989).

When fluid flow increases beyond a certain limit, inertial force, not viscosity force, becomes the dominant factor governing fluid flow (Fetter, 2001). Streamlines are no longer straight. Kinetic energy causes water molecules to follow erratic lines and the flow is described as turbulent.

Dual flow is a type of flow where both Darcian and non-Darcian flow occur in the same area. Due to the anisotropic and heterogeneous nature of a karst aquifer it may be necessary to treat it as an interconnected conduit system in a more or less porous (or fissured) matrix (Ford and Williams, 1989). It is largely a matter of fissure frequency and scale which method of analysis is used (Snow 1968; 1969). The heterogeneity of the hydraulic conductivity field may be schematized by a high permeability, generally unknown channel network with kilometer wide "meshes", which is "immersed" in a low permeability fractured limestone volume (Kiraly, 1994).

Permeameter tests done in this study were considered to have been conducted under Darcian flow conditions. Most of the hydraulic conductivity values obtained from the cubes plotted in a straight line, including the high head test (Figure 4.11, Figure 4.12, Appendex B). A non-linear plot would have indicated non Darcian flow. Reynolds number calculations indicate that even with the highest head values used in permeameter 
testing, a vug $1 \mathrm{~cm}$ in radius would be needed to produce a Reynolds number greater than

5. Inspection of the cubes showed the presence of a few vugs $1 \mathrm{~cm}$ in radius, but none of these vugs penetrated entirely through the cube. Turbulent flow may occur with increasingly large pores, but probably is not maintained throughout the cube. One third of the plots of hydraulic conductivity from the permeameter tests show some curvature of the data points. Although the high head test and Reynolds number calculations indicate Darcian flow conditions this curvature may indicate the beginning of departure from Darcian flow.

Slug tests may or may not have been conducted under Darcian flow conditions. The lower hydraulic conductivity values obtained with the largest slugs may be an indication of non-Darcian conditions. Had turbulence occurred, hydraulic conductivity values calculated would have been underestimations of the actual hydraulic conductivity.

The Biscayne Aquifer has many areas of increased porosity. An area of increased porosity is an area where the porosity in the immediate area is significantly higher than the average porosity of the formation. Such areas have been shown with geophysical surveys (Cunningham and Aviantara, 2001), by drops of drill rods while drilling (Wilcox, 2000), surface observations (Price et al., 2003), and by stable isotope studies (Wilcox, 2000). A well encountering an area of increased porosity may react in a turbulent manner to a slug test. Pump tests, which cover a larger area than slug tests have a higher chance of encountering a conduit with turbulent flow. 


\subsection{Anisotropy}

When hydraulic conductivity is the same regardless of direction of measurement the aquifer is isotropic, but if hydraulic conductivity varies with the direction of measurement the aquifer is anisotropic (Ford and Williams, 1989). Should anisotropy exist, ground water will be conducted better in one direction than in another (Kiraly, 2003). Conduit-flow pathways within the Fort Thompson Formation are produced by well-connected, solution-enlarged pore space (Cunningham and Aviantara, 2001). Alignment of these conduits would create a preferential flow direction. In this study three mutually perpendicular axes in each cube of Key Largo Limestone were compared for differences in hydraulic conductivity. Plotting hydraulic conductivity ellipses facilitated this comparison between axes. Axes of each ellipse were the square root of the hydraulic conductivity ( $\mathrm{m} /$ day) of the vertical axis and the average of the horizontal axes (Figure 4.6, Figure 4.10). Circles would be formed if the values of the vertical and horizontal axes were equal. If an ellipse is formed there is anisotropy between the axes. The more elliptical the shape, the more anisotropy exists. The larger axis of the ellipse shows the axis of preferred flow.

In the $20 \mathrm{~cm}$ Key Largo Limestone cubes 1, 3, and 5 show anisotropy in which vertical hydraulic conductivity is favored over horizontal conductivity (Figure 4.6). Cubes 2 and 6 show virtually no anisotropy. Cubes 4 and 7 show anisotropy with horizontal hydraulic conductivity being favored over vertical hydraulic conductivity. Cube 6 was located immediately above the dense laminated layer and was noticeably more porous than the other cubes, which explains the higher over all hydraulic conductivity. Cube 7 contained part of the dense laminated layer, which is shown by a 
reduction in the vertical hydraulic conductivity in comparison to the horizontal conductivity in that cube. Cube 1 shows higher vertical hydraulic conductivity than cube 2 due to channels made by roots.

In the $30 \mathrm{~cm}$ Key Largo Limestone cubes 1 and 2 anisotropy is shown with the vertical axis preferred (Figure 4.10). These cubes were closest to the land surface. Cube 1 shows higher vertical hydraulic conductivity than cube 2 due to channels made by roots. Cubes 3 and 4 show little anisotropy. Cubes 5 and 6 show tremendous anisotropy with horizontal hydraulic conductivity being favored over vertical hydraulic conductivity. The presence of the dense laminated layer within these two cubes significantly reduces flow in the vertical direction. In general hydraulic conductivity increased with depth in the $30 \mathrm{~cm}$ cubes.

The sedimentology of the Key Largo Limestone cubes was discussed in detail by K. Cunningham of the United States Geological Survey (personal communication, 2005). The Key Largo Limestone cubes tested were highly granular. The lack of laminations that would be caused in a high-energy depositional environment indicates the material was originally deposited in a lagoonal setting. This depositional setting would be comparable to modern day Florida bay. The Key Largo Limestone material was extensively burrowed. Dissolution of these burrows has increased the porosity. A dense laminated layer was contained in the large block from which the cubes were cut. This feature may have been caused by scouring or may be the result of by-product material from burrowing activities. The feature is noticeably denser than the surrounding block material, contains little organic material, and has only sparse reworked root features. This feature creates tremendous anisotropy in cubes that contain it. Vertical hydraulic 
conductivity through the feature is reduced while horizontal hydraulic conductivity is enhanced below the feature. The exception to this is $20 \mathrm{~cm}$ cube number 6 , which is above the dense laminated layer, but has increased hydraulic conductivity. The effect of this feature on contaminant transport would be to reduce infiltration across the feature, but once passed transport would be extremely fast with the ground water flow.

\subsection{Applications of results}

The Key Largo Limestone cubes used in this study were cut from a block that was situated mostly above the prevailing water table. Cubes 6 and 7 in the $20 \mathrm{~cm}$ size, and cubes 5 and 6 in the $30 \mathrm{~cm}$ size had portions that were below a dense laminated layer. These cubes showed noticeably more porosity than cubes above the dense laminated layer. Cubes 6 and 7 in the $20 \mathrm{~cm}$ size had an average total porosity of 48 percent. In comparison, cubes $1,2,3,4$, and 5 had total average porosity of 40 percent. Cubes 5 and 6 in the $30 \mathrm{~cm}$ size had an average total porosity of 52 percent. In comparison, cubes 1 , 2,3 , and 4 , had average total porosity of 43 percent.

Cubes from below the dense laminated layer showed higher hydraulic conductivity values than cubes cut from above the dense laminated layer. Cubes 6 and 7 in the $20 \mathrm{~cm}$ size had an average hydraulic conductivity of $23 \mathrm{~m} /$ day. In comparison, cubes $1,2,3,4$, and 5 had an average hydraulic conductivity of $3.4 \mathrm{~m} /$ day. Cubes 5 and 6 in the $30 \mathrm{~cm}$ size had an average hydraulic conductivity of $30 \mathrm{~m} /$ day. In comparison, cubes $1,2,3$, and 4 , had an average hydraulic conductivity of $1.1 \mathrm{~m} /$ day.

Aquifer properties in the Key Largo Limestone are variable depending on weather above or below the dense laminated layer. Above the dense laminated layer, hydraulic conductivity values were low, porosity was low and there was no detectable anisotropy. 
Below the dense laminated layer hydraulic conductivity was high, porosity was high and there was a noticeable anisotropy. The extensiveness of the dense laminated layer is unknown at this time. The results of this research demonstrate a range in aquifer properties for the Key Largo Limestone formation that can be used in hydrologic modeling.

All slug tests in this study were conducted in a saturated portion of the Miami Oolite Formation. Hydraulic conductivity values obtained ranged from $100 \mathrm{~m} /$ day to 200 m/day. Hydraulic conductivity values obtained from slug tests in this study are most applicable in saturated ground water flow applications in Miami Oolite. 
Table 5.1 Comparison of total porosity on core plugs and whole core samples from the Biscayne Aquifer from Cunningham et al., 2004

\begin{tabular}{|l|c|c|}
\hline & Core plug & Whole core \\
\hline Mean & 24.7 & 22.3 \\
\hline Std. Dev & 9.51 & 10.7 \\
\hline Std. Err & 1.58 & 1.27 \\
\hline $95 \%$ Conf & 3.21 & 2.53 \\
\hline $99 \%$ Conf & 4.31 & 3.36 \\
\hline Size & 36 & 71 \\
\hline Total & 892 & 1585 \\
\hline Min & 6.6 & 5.9 \\
\hline Max & 46.6 & 49.3 \\
\hline
\end{tabular}


Table 5.2 Comparison of hydraulic conductivity values of Karst Aquifers

\begin{tabular}{|c|c|c|c|}
\hline Aquifer & Age & $\mathrm{K}$ (m/day) & Reference \\
\hline Biscayne & Pleistocene & $5.1 \times 10^{-2}$ to $10^{4}$ & $\begin{array}{l}\text { This study/Fish } \\
\text { and Stewart, } \\
1991\end{array}$ \\
\hline Floridan & Tertiary & $1 \times 10^{-4}$ to $2.2 \times 10^{2}$ & $\begin{array}{l}\text { Hayes et } \\
\text { al.,1983 }\end{array}$ \\
\hline Edwards & Cretacious & $3.0 \times 10^{-1}$ to $3.05 \times 10^{2}$ & $\begin{array}{l}\text { Barker and } \\
\text { Ardis, } 1996\end{array}$ \\
\hline Lucayan & Pleistocene & $10^{-6.4}$ to $10^{4}$ & $\begin{array}{l}\text { Whitaker and } \\
\text { Smart, } 2000\end{array}$ \\
\hline Mallorca & Pleistocene & $\begin{array}{l}10^{2} \text { to } 2.0 \times 10^{3} \\
\text { (These values are } \\
\text { from cores only) }\end{array}$ & $\begin{array}{l}\text { Price and } \\
\text { Herman, } 1991\end{array}$ \\
\hline
\end{tabular}




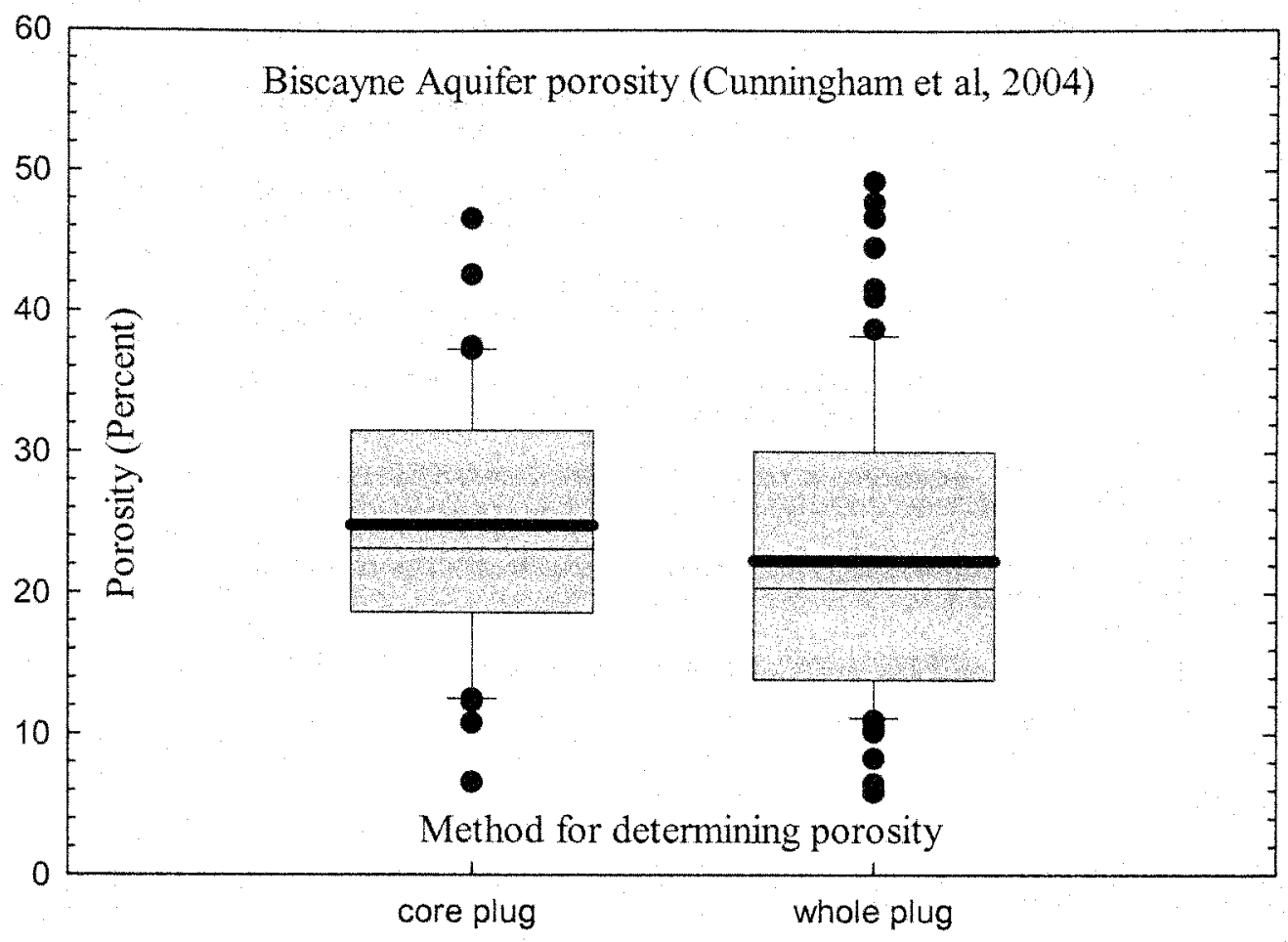

Figure 5.1 Box plot showing porosity values for core plugs and whole plugs. Dark lines indicate mean values, circles indicate outliers (Adapted from Cunningham, 2004). 


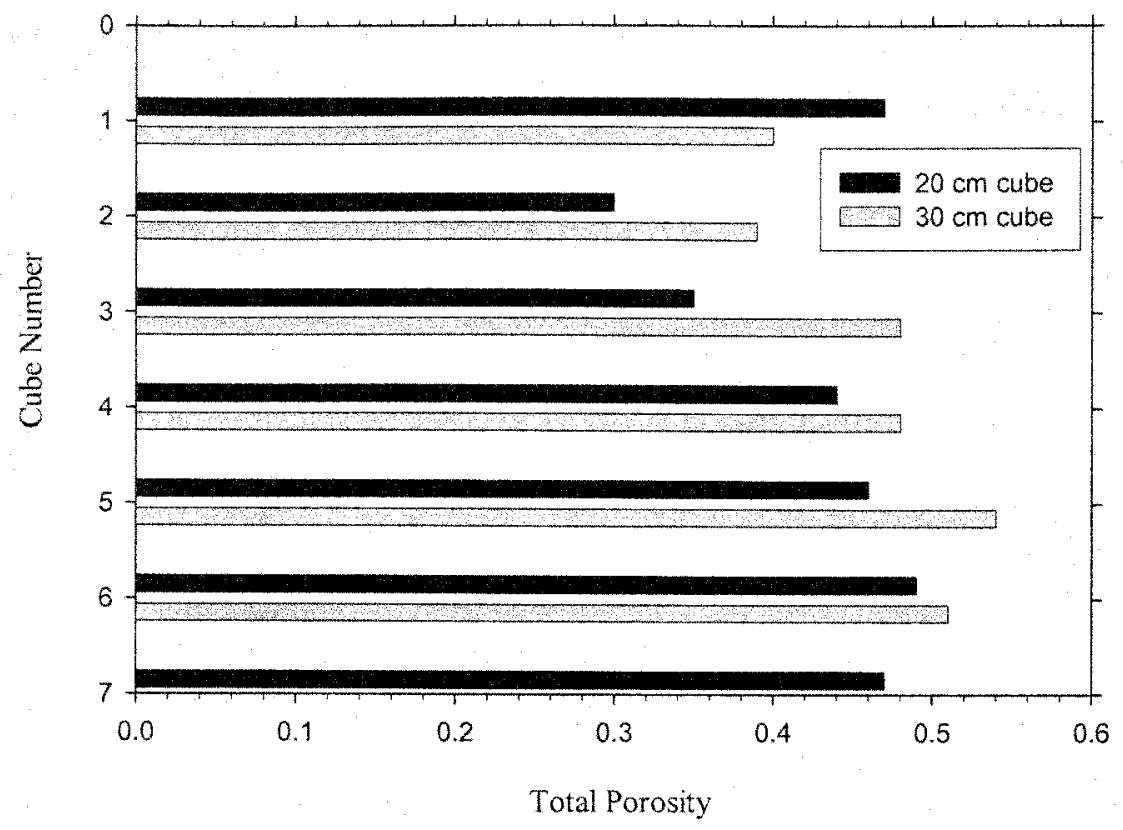

Figure 5.2 Comparison of total porosity of $20 \mathrm{~cm}$ and $30 \mathrm{~cm}$ Key Largo Limestone cubes.

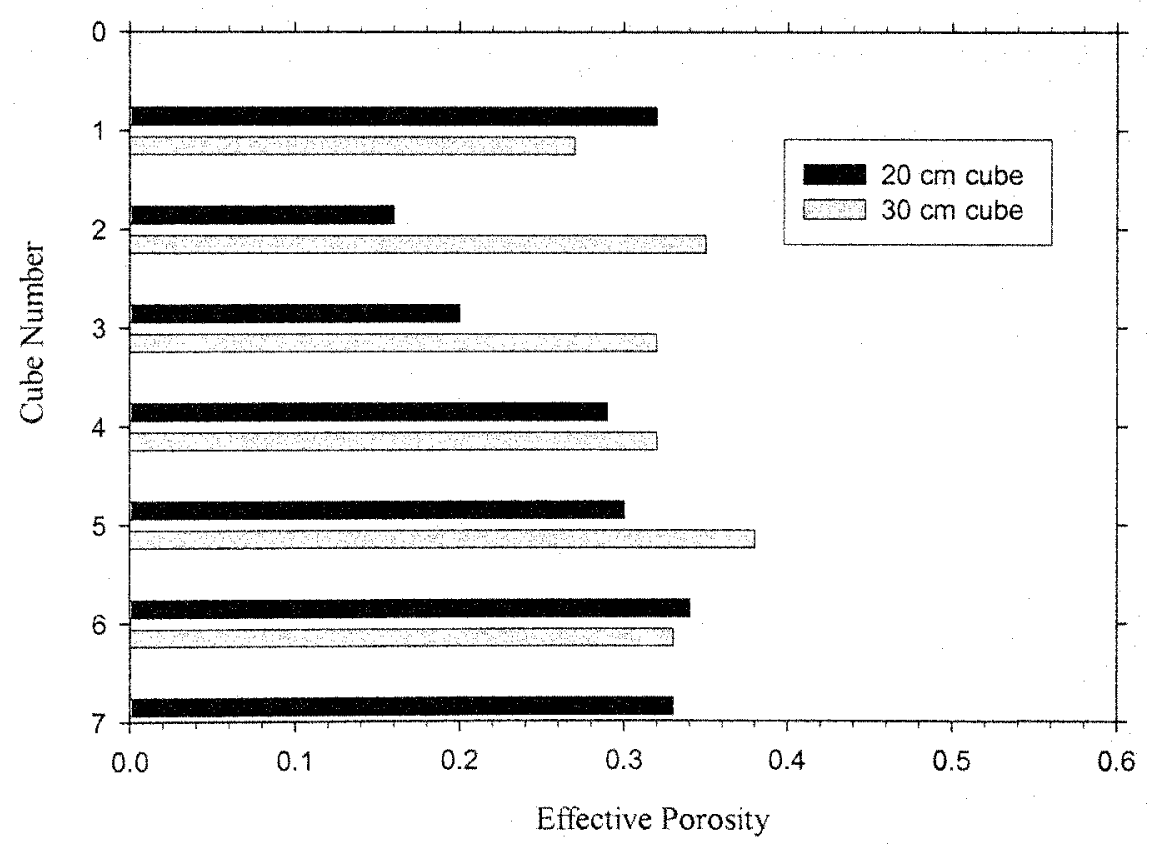

Figure 5.3 Comparison of effective porosity of $20 \mathrm{~cm}$ and $30 \mathrm{~cm}$ Key Largo Limestone cubes. 


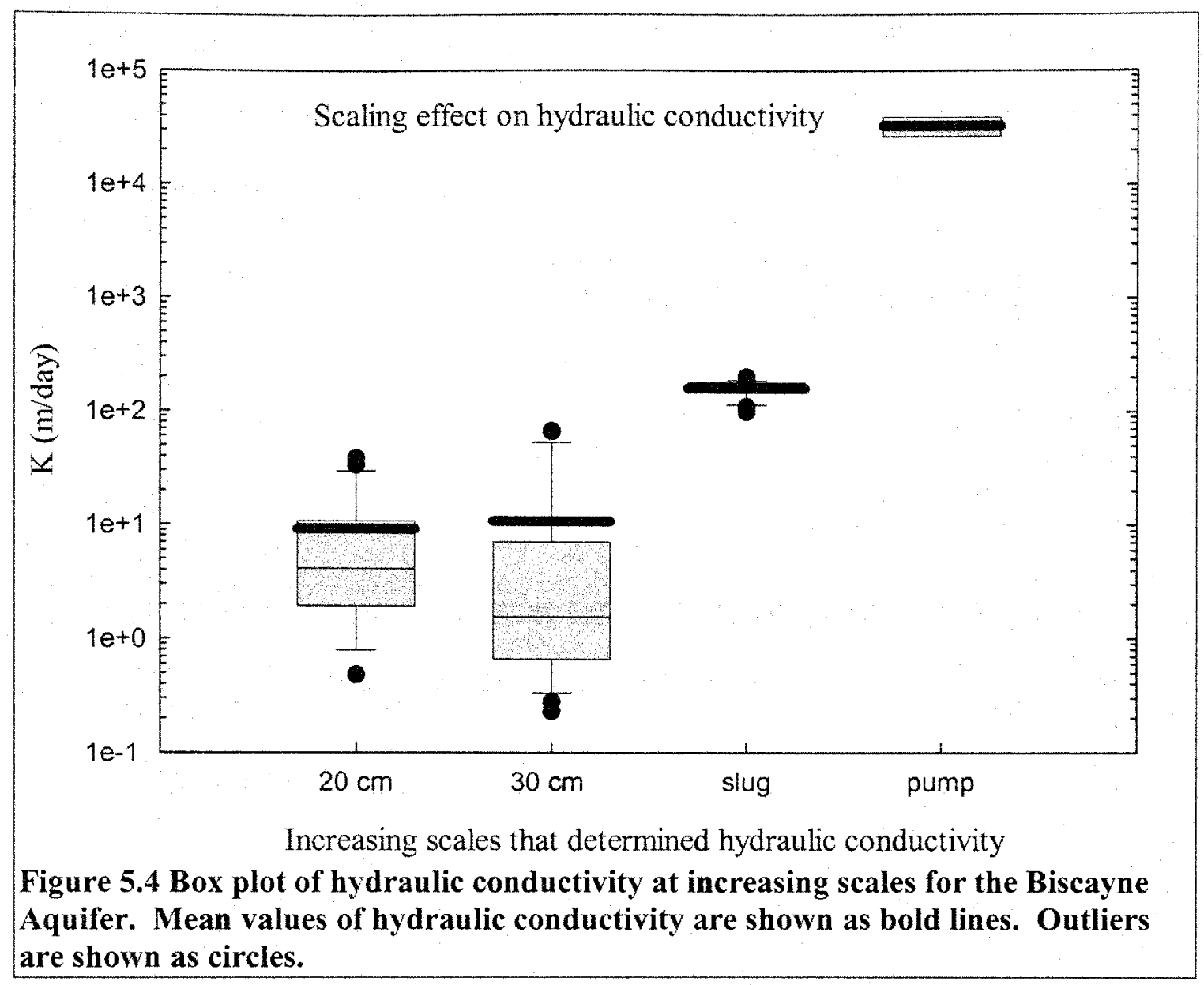




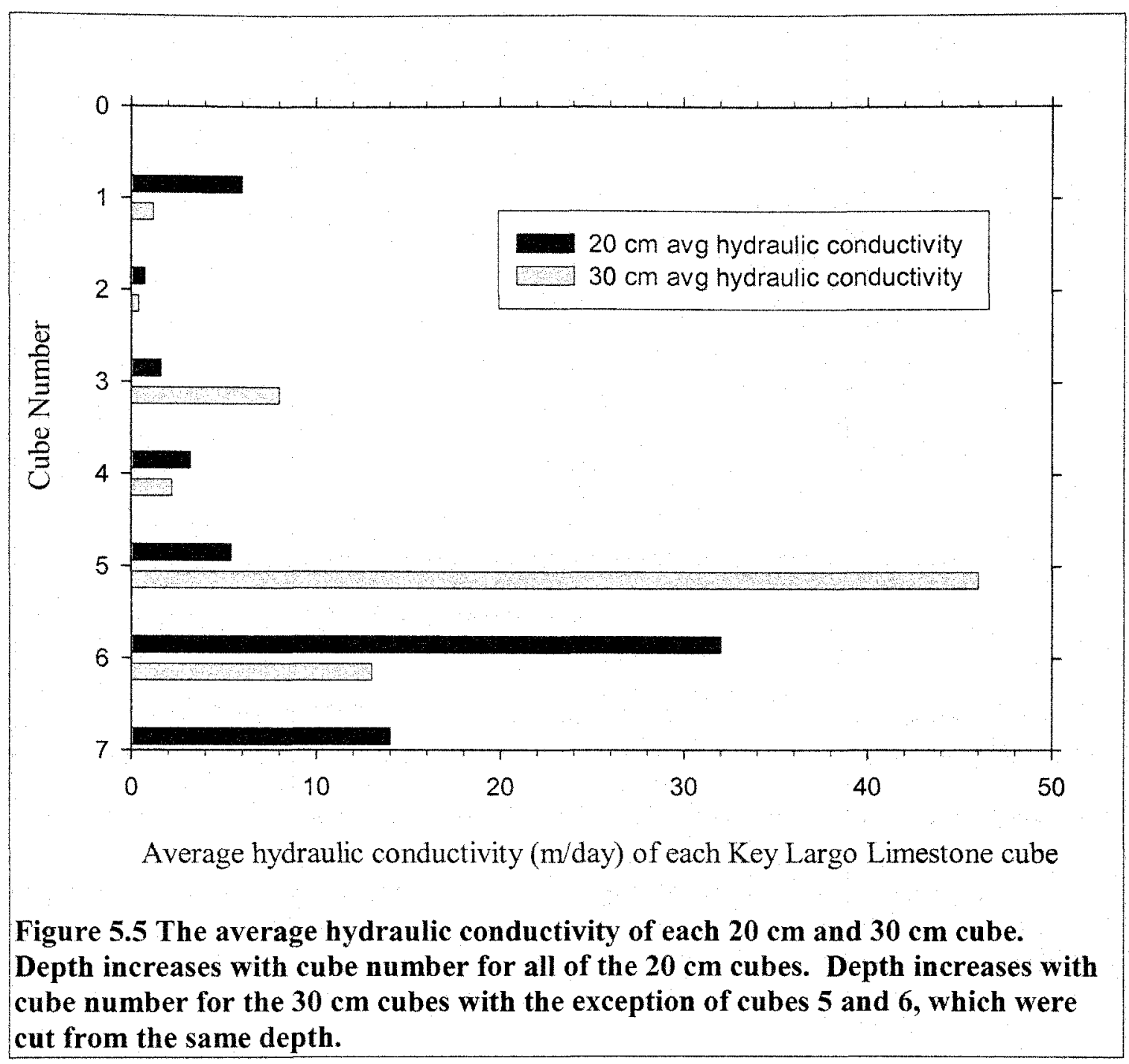




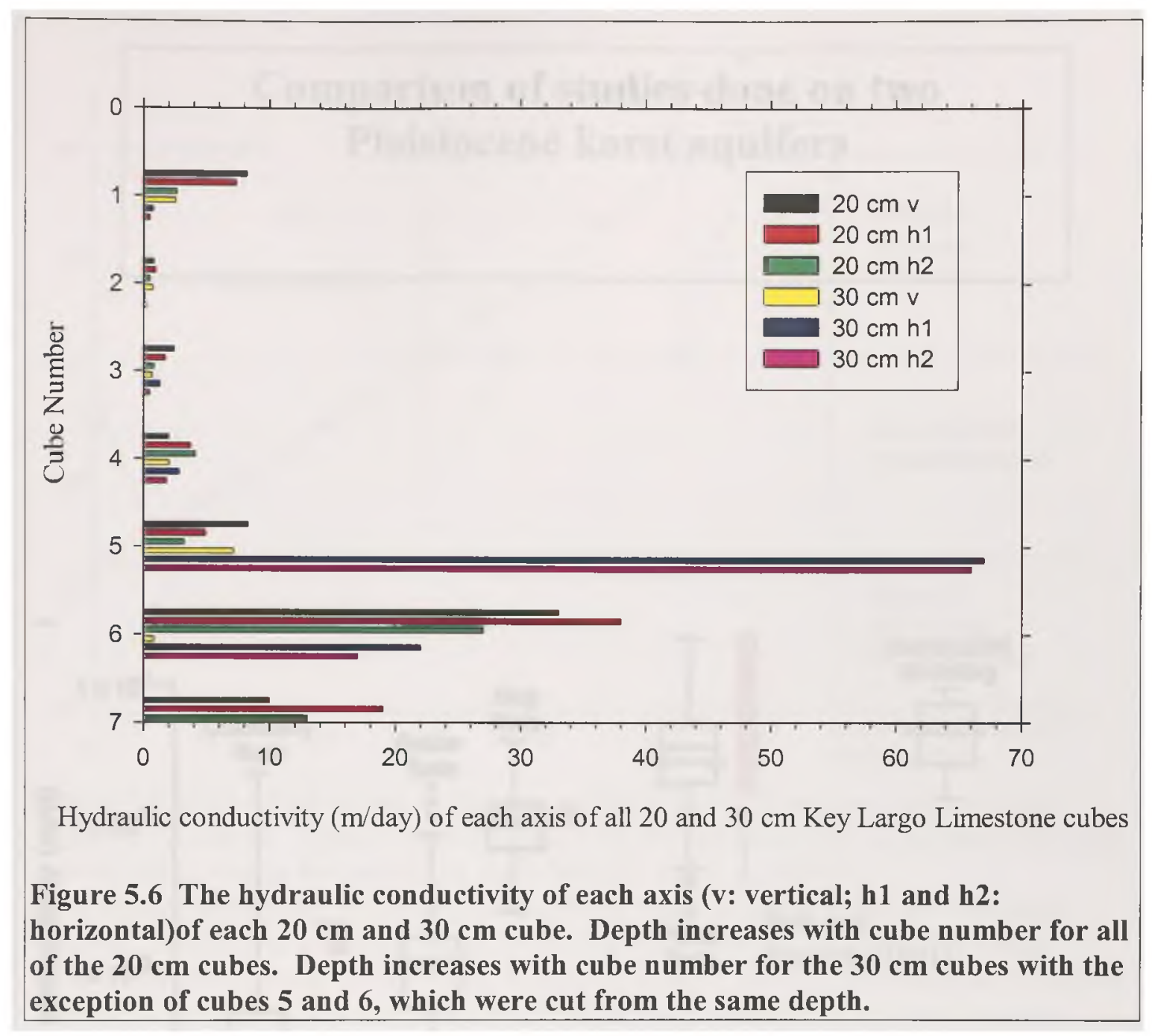




\section{Comparison of studies done on two Pleistocene karst aquifers}

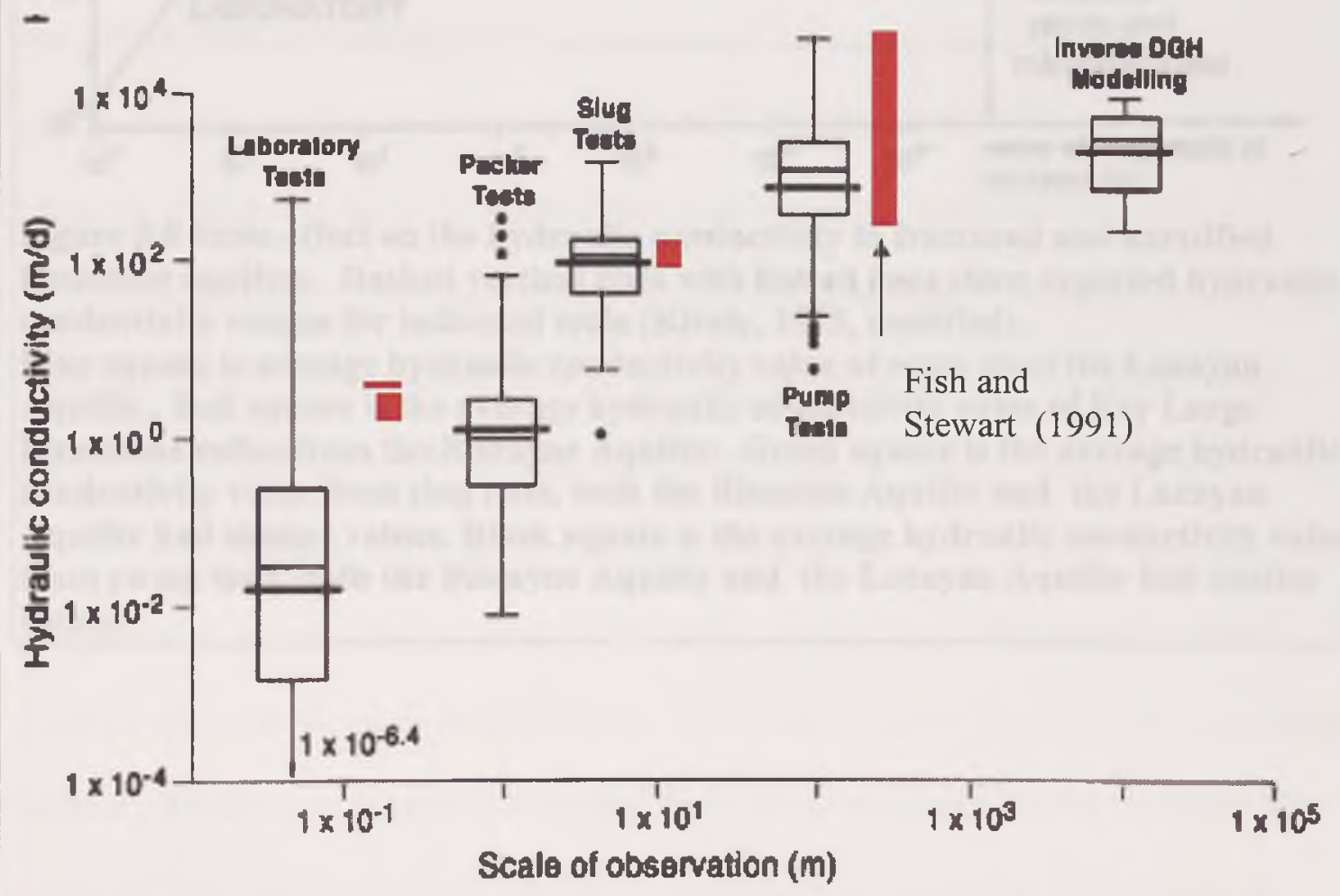

Figure 5.7 Diagram shows hydraulic conductivity values from the Lucayan aquifer in the Bahamas (in box and whisker plots) and the hydraulic conductivity values of this study in the Biscayne aquifer (in red). 


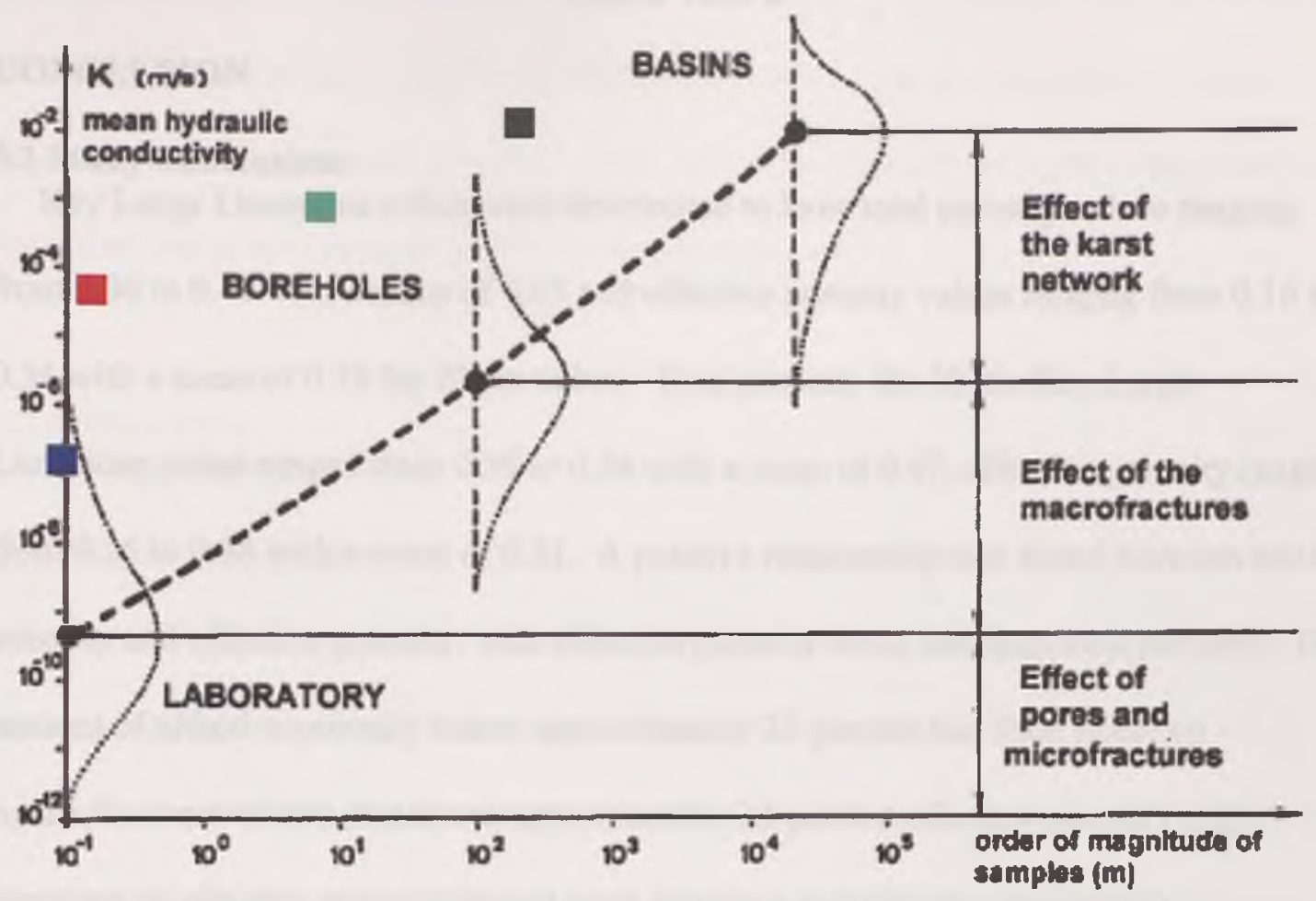

Figure 5.8 Scale effect on the hydraulic conductivity in fractured and karstified limestone aquifers. Dashed vertical lines with bowed lines show expected hydraulic conductivity ranges for indicated scale (Kiraly, 1975, modified).

Blue square is average hydraulic conductivity value of cores from the Lucayan Aquifer. Red square is the average hydraulic conductivity value of Key Largo Limestone cubes from the Biscayne Aquifer. Green square is the average hydraulic conductivity value from slug tests, both the Biscayne Aquifer and the Lucayan Aquifer had similar values. Black square is the average hydraulic conductivity value from pump tests, both the Biscayne Aquifer and the Lucayan Aquifer had similar values. 


\section{CHAPTER 6}

\section{CONCLUSION}

\subsection{Study Conclusions}

Key Largo Limestone cubes were determined to have total porosity values ranging from 0.30 to 0.49 with a mean of 0.43 and effective porosity values ranging from 0.16 to 0.34 with a mean of 0.28 for $20 \mathrm{~cm}$ cubes. Total porosity for $30 \mathrm{~cm}$ Key Largo Limestone cubes ranged from 0.39 to 0.54 with a mean of 0.47 , effective porosity ranged from 0.25 to 0.38 with a mean of 0.31 . A positive relationship was found between total porosity and effective porosity, with effective porosity being less than total porosity. The amount of effective porosity below approximately 33 percent had little effect on hydraulic conductivity, but above approximately 33 percent effective porosity slight increases in effective porosity caused large increases in hydraulic conductivity.

Hydraulic conductivity was found to increase with scale in the Biscayne Aquifer. Key Largo Limestone cubes were determined to have hydraulic conductivity values ranging from $0.74(\mathrm{~m} /$ day) to $32(\mathrm{~m} /$ day) with a mean of $8.9(\mathrm{~m} /$ day) for $20 \mathrm{~cm}$ cubes and a range of $0.8(\mathrm{~m} /$ day) to $46(\mathrm{~m} /$ day $)$ with a mean of $10(\mathrm{~m} /$ day $)$ for $30 \mathrm{~cm}$ cubes. Slug tests were determined to have hydraulic conductivity values ranging from 100 (m/day) to 200 ( $\mathrm{m} /$ day) with a mean value of $160(\mathrm{~m} /$ day). Hydraulic conductivity values for pump tests in Miami Oolite from the literature ranged from 7,300 (m/day) to $12,000(\mathrm{~m} /$ day $)$ with a mean of $9,900(\mathrm{~m} /$ day). The $20 \mathrm{~cm}$ and $30 \mathrm{~cm}$ Key Largo Limestone cubes were cut from a block that appears to have been mostly above the water table. Low hydraulic conductivity values were obtained from the $20 \mathrm{~cm}$ cube cut above a dense laminated layer, below the dense laminated layer, horizontal hydraulic conductivity vales were 
higher than above the dense laminated layer. Anisotropy was greatest in the cubes cut below the dense laminated layer with higher hydraulic conductivity in the horizontal direction versus the vertical direction. High hydraulic conductivity values correlated with porosities grater than approximately thirty three percent.

\subsection{Future work}

Cubes cut from the Miami Oolite Formation and the Fort Thompson Formation would give valuable results for modeling infiltration and saturated flow in these formations. Cutting Miami Oolite cubes from the Homestead General Airport, where the slug tests were conducted, would help to show the effects of scaling on hydraulic conductivity in this formation. Additionally cubes known to be below the water table in the Key Largo Limestone Formation would give valuable data for modeling saturated flow. Slug tests performed in wells in the Key Largo Limestone Formation would help to show the effects of scaling in this formation as the hydraulic conductivity values could be compared to hydraulic conductivity values obtained from the cubes. 


\section{REFERENCES}

Ambegaokar V., B. I. Halperin, and J. S. Langer. 1971. Hopping conductivity in disordered systems. Physical Review, v. 4, 2612-2620.

Anselmetti, F. S., S. Luthi, and G. P. Eberli. 1998. Quantitative characterization of carbonate pore systems by digital image analysis. AAPG Bulletin, v. 82, n. 10, $1815-1836$.

Barker, R. A. and A. F. Ardis. 1996. Hydrogeologic framework of the Edwards-Trinity aquifer system, west-central Texas. U.S. Geological Survey Professional Paper 1421-B, 61 p. with plates.

Boghici, R. 2002. Transboundry aquifers of the del rio/ciudad acuna-Laredo Nuevo Laredo Region. Texas water development board 996343-01-1, 221 p.

Bolster, C. H., D. P. Genereux, and J. E. Saiers. 2001. Determination of specific yield for the Biscayne Aquifer with a canal-drawdown test. Ground Water, Sep-Oct v.39, n.5, 768-777.

Broska, J. C., and H. L. Barnette. 1999. Hydrogeology and analysis of aquifer characteristics in West-Central Pinellas County, Florida. U.S. Geological Survey Open-File Report 99-185, 23 p.

Budd, D. A. 2001. Permeability loss with depth in the Cenozoic carbonate platforms of west-central Florida. American Association of Petroleum Geologists Bulletin, v. $85,1253-2172$.

Butler, J. J. Jr., E. J. Garnett, and J. M. Healey. 2003. Analysis of slug tests in formations of high hydraulic conductivity. Ground Water, Sep-Oct v. 41, n.5, 620-630.

Chen, D. W., R. F. Carsel., L. Moeti., and B. Vona. 1999. Assessment and prediction of a contaminant transport and migration at a Florida superfund site. Environmental Monitoring and Assessment, v. 57, n.3, 291-299.

Comprehensive Everglades Restoration Plan Website, http://www.evergladesplan.org/about/rest plan.cfm.

Cunningham, K. J., and A Aviantra. 2001. Characterization of the karst Biscayne aquifer in southeastern Florida using ground-penetrating radar, digital optical borehole images and cores. Karst Interest Group Proceedings, U.S. Geological Survey., St. Petersburg, Fl, $134 \mathrm{p}$. 
Cunningham, K. J., Carlson, J.L., Wingard, G.L., Robinson, E., and Wacker, M.A. 2004. Characterization of aquifer heterogeneity using cyclostratigraphy and geophysical methods in the upper part of the karstic Biscayne Aquifer, Southeastern Florida. U.S. Geological Survey Water-Resources Investigations Report 03-4208, 66 p., 5 appendixes (on CD), and 5 plates.

Darcy, H. 1856. Les fontanes publiques de la ville de Dijon. Paris Victor Dalmont, 351 p.

Drew, D. P., and H. Hotzl. 1999. Karst hydrogeology and human activities: Impacts, Consequences and Implications. Brookfield: A.A. Balkema, 332 p.

Federal Register Notice, October 11, 1979, v.44, no.198.

Fetter, C. W. 2001. Applied Hydrogeology. New Jersey: Prentice-Hall, Inc, 598 p.

Fish, J. E., and M. Stewart. 1991. Hydrogeology of the Surficial aquifer system in Dade County Florida. U. S. Geological Survey Water-Resources Investigations Report 90-4108, 50 p.

Ford, D., and P. Williams. 1989. Karst Morphology and Hydrogeology. Winchester: Unwin Hyman, 320 p.

Freeze, R. A., and J. A. Cherry. 1979. Groundwater. New Jersey: Prentice-Hall, 604 p.

Friedman, S.P., and N. A. Seaton. 1998. Critical path analysis of the relationship between permeability and electrical conductivity of three-dimensional networks. Water Resources Research, v. 34, n. 7, 1703-1710.

Genereux, D. P., J. D. A. Guardiario Jr. 1998. A canal drawdown experiment for determination of aquifer parameters. Journal of Hydrologic Engineering, v.3, 294-302.

Hayes, R. H., M. L. Maslia, and W. C. Meeks. 1983. Hydrology and model evaluation of the principal artesian aquifer, Dougherty Plain, southwest Georgia. Georgia Geologic Survey Bulletin 97, 93 p.

Hovorka, S. D., S. C. Ruppel, A. R. Dutton, and J. Yeh. 1993. Edwards aquifer storage assessment, Kinney County to Hays County, Texas: Bureau of Economic Geology, Austin, Texas, 101 p.

Kacaroglu, F. 1999. Review of groundwater pollution and protection in karst areas. Water, Air, and Soil Polution, v. 113, n.1-4, 337-356.

Kiraly, L. 2003. Karstification and groundwater flow. Speleogenesis and evolution of Karst Aquifers, v.1, n.3, 26 p. 
Kiraly, L. 1994. Groundwater flow in fractured rocks: models and reality. 14. Mintrop seminar uber Interpretationsstrategein in Exploration und Produktion, Ruhr Universitat Bochum 159/1-21.

Kiraly, L. 1975. Rapport sur l'état actuel des connaissances dans le domaines des caractères physiques des roches karstiques. In: Burger A. and Dubertret L. (Eds), Hydrogeology of karstic terrains, Int. Union of Geol. Sciences, v. B, n. 3, 53-67.

Klein, H., and J. E. Hull. 1978. Biscayne aquifer southeast Florida. US Geological Survey Water-Resources Investigations 78-107, $57 \mathrm{p}$.

Knochenmus, L. A., and J. L. Robinson. 1996. Descriptions of anisotropy and heterogeneity and their effect on ground water flow and areas of contribution to public supply wells in a karst carbonate aquifer system. United States Geological Survey Water-Supply Paper 2475, 45 p.

Koponen, A., M. Kataja, and J. Timonen. 1996. Permeability and effective porosity of porous media. Phys. Rev. v 56. 3319-3325.

Kuniansky, E.L., L. Fahlquist, A.F. Ardis. 2001. Travel times along selected Flow paths of the Edwards Aquifer, Central Texas. U.S. Geological Survey Karst Interest Group Proceedings, Water-Resources Investigations Report 01-4001. 69-77

Langevin, C.D. 2001. Simulation of Ground Water discharge to Biscayne Bay, Southeastern Florida. U.S. Geological Survey Water-Resources Investigations Report 00-4251, $137 \mathrm{p}$.

LaMoreaux, P. E., and B. M. Wilson. 1984. Guide to the hydrology of carbonate rocks. Paris: UNESCO, $345 \mathrm{p}$.

Leach, S. D., H. Klein, and B. R. Hampton. 1972. Hydrologic effects of water control and management of southeastern Florida. Florida Bureau of Geology Report Investigation $60,115 \mathrm{p}$.

Lohman, S. W., R. R. Bennett, R. H. Brown, H. H. Cooper Jr. W. J. Drescher, J. G. Ferris, I. Johnson, C. L. M ${ }^{\mathrm{c}}$ Guinness, M. Piper, M. I. Rorobaugh, R. A. Stallman, and C. V. Theis. 1972. Definitions of selected ground-water terms--Revisions and conceptual refinements. U.S. Geological Survey Water-Supply Paper 1988, 9 p.

Miami-Dade County Quickfacts Website. http://quickfacts.census.gov/qfd/states/12/12086.html. 
Merritt, M. L. 1997. Simulation of the water-table altitude in the Biscayne Aquifer, Southern Dade County, Florida, water years 1945-1989. U.S. geological Survey Water-Supply Paper 2458, 148 p.

Miller, J. A. 1990. Ground water atlas of the United States Alabama, Florida, Georgia, South Carolina. U. S. Geological Survey HA 730-G, 28 p.

Moore, D. S., and G. P. McCabe. 2003. Introduction to the Practice of Statistics fourth edition. New York: W. H. Freman and Company, 828 p.

Price, R. M., Z. Top, J. D. Happell, and P. Swart. 2003. Use of tritium and helium to define groundwater flow conditions in Everglades National Park. Water Resources Research, v. 39, n. 9, 12 p.

Price, R. M., and J. S. Herman. 1991. Geochemical investigation of salt-water intrusion into a coastal carbonate aquifer: Mallorca, Spain. Geological Society of America Bulletin, v. 103, 1270-1279.

Pulido-Bosch, A. 1999. Karst water exploitation. International Contributions to Hydrogeology, v. 20 A.A. Balkema, Rotterdam, The Netherlands, 225-234.

Sasowsky, I. D., and C. M. Wicks. 2000. Groundwater Flow and Contaminant Transport in Carbonate Aquifers. Brookfield: A. A. Balkema, 193 p.

Sieh, T. W. 1975. Edward (Balcones fault zone) aquifer test well drilling investigation: unpublished report in files of Texas Department Water Resources, $117 \mathrm{p}$.

Schulze-Makuch, D., and D. S. Cherkauer. 1998. Variations in hydraulic conductivity with scale of measurement during aquifer tests in heterogeneous, porous carbonate rocks. Hydrogeology Journal, v. 6, n. 2, 204-215.

Small, T. A., and R. W. Maclay. 1982. Test-hole data for the Edwards aquifer in the San Antonio area, Texas. Texas Department of Water Resources LP-171, $153 \mathrm{p}$.

Snow, D. T. 1969. Anisotropic permeability of fractured media. Water Resources Res, v. 5, 1273-89.

Snow, D. T. 1968. Rock fracture spacings, openings, and porosities. J. Soil Mech. Found. Div., Amer. Soc. Civil Engineers, v. 94, 73-91.

South Florida Water Management District. 1999. South Florida Water Management Model Version 3.5. West Palm Beach, Fl. 233 p.

SPSS Inc. 1999. SPSS Base 10.0 for Windows User's Guide. SPSS Inc., Chicago Il. 
Spss Inc. 2001. SigmaPlot version 7 for windows., Chicago Il.

Sukop, M. C., G. Van Dijk, E Perfect, and W. K. P. Van Loon. 2002. Percolation thresholds in 2-dimensional prefractal models of porous media. Transport in Porous Media, v. 48, 187-208.

Ward, W. C., K. J. Cunningham, R. A. Reneken, M. A. Wacker, and J. I. Carlson. 2003. Sequence-stratigraphic analysis of the regional observation monitoring program (ROMP) 29A test corehole and its relation to Carbonate Porosity and Regional Transmissivity in the Floriday Aquifer system, Highlands County, Florida. U.S. Geological Survey Open-File Report 03-201, 33 p.

Whitaker, F. F., P. L. Smart. 2000. Characterizing scale-dependence of hydraulic conductivity in carbonates: evidence from the Bahamas. Journal of geochemical exploration, v. 69-70, 133-137.

White, W. B. 1989. Introduction to the hydrology of the mammoth cave area, In Karst Hydrology concepts from the Mammoth Cave Area, ed. W. B. White, and E. L. White, New York: Van Nostrand Reinhold, 288 p.

Wilcox, W. M. 2000. A hydrological and stable isotope study of east Everglades National Park and the west well field of Miami-Dade County, Florida. M.S. thesis, 176 p., Univ. of Miami, Coral Gables Fl, 
APPENDIX A

Figures of permeameter assembly 


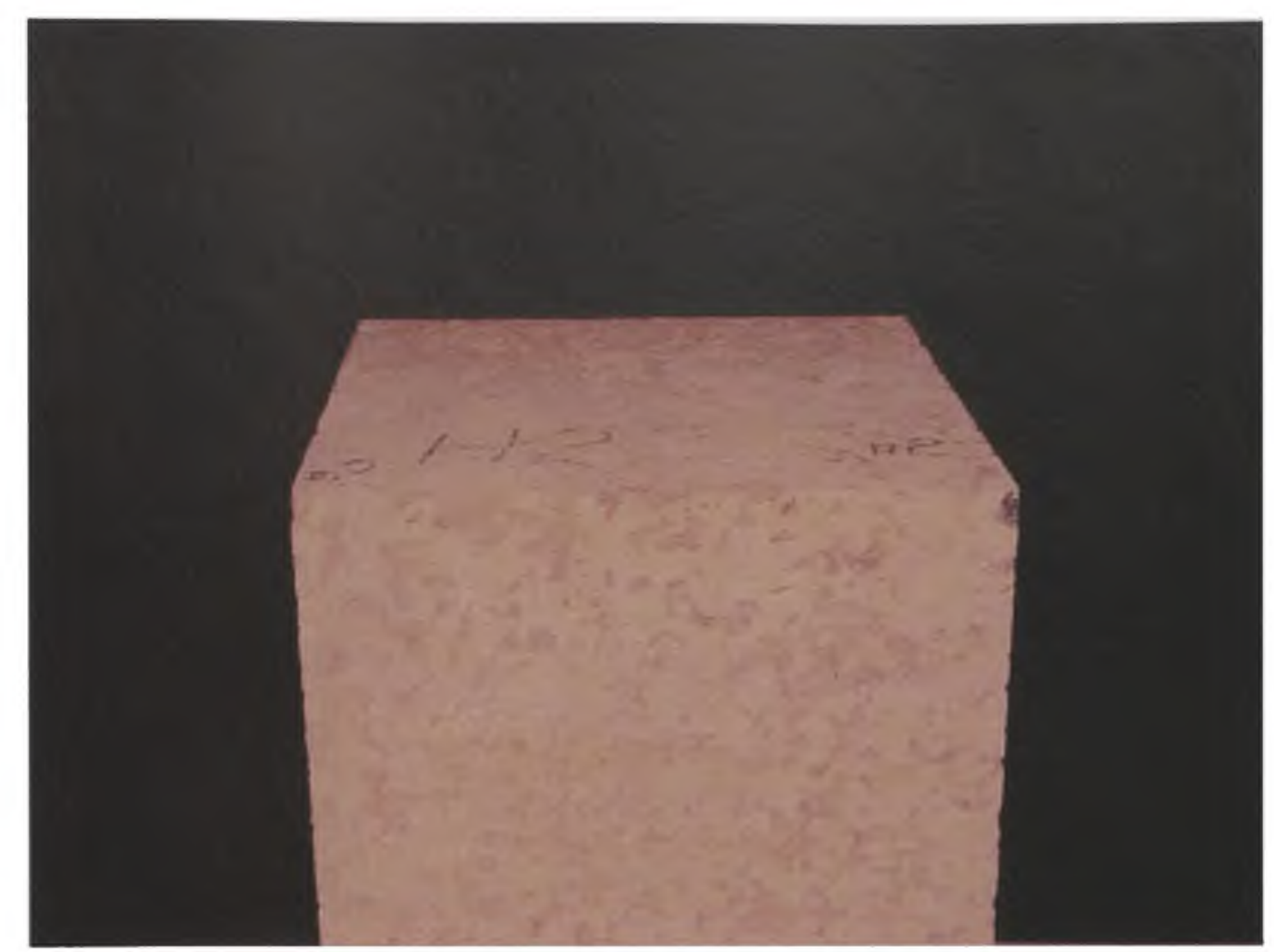

A.1 The $30 \mathrm{~cm}$ Key Largo Limestone cube number 2, h2 axis, being prepared for hydraulic conductivity testing in the permeameter. 


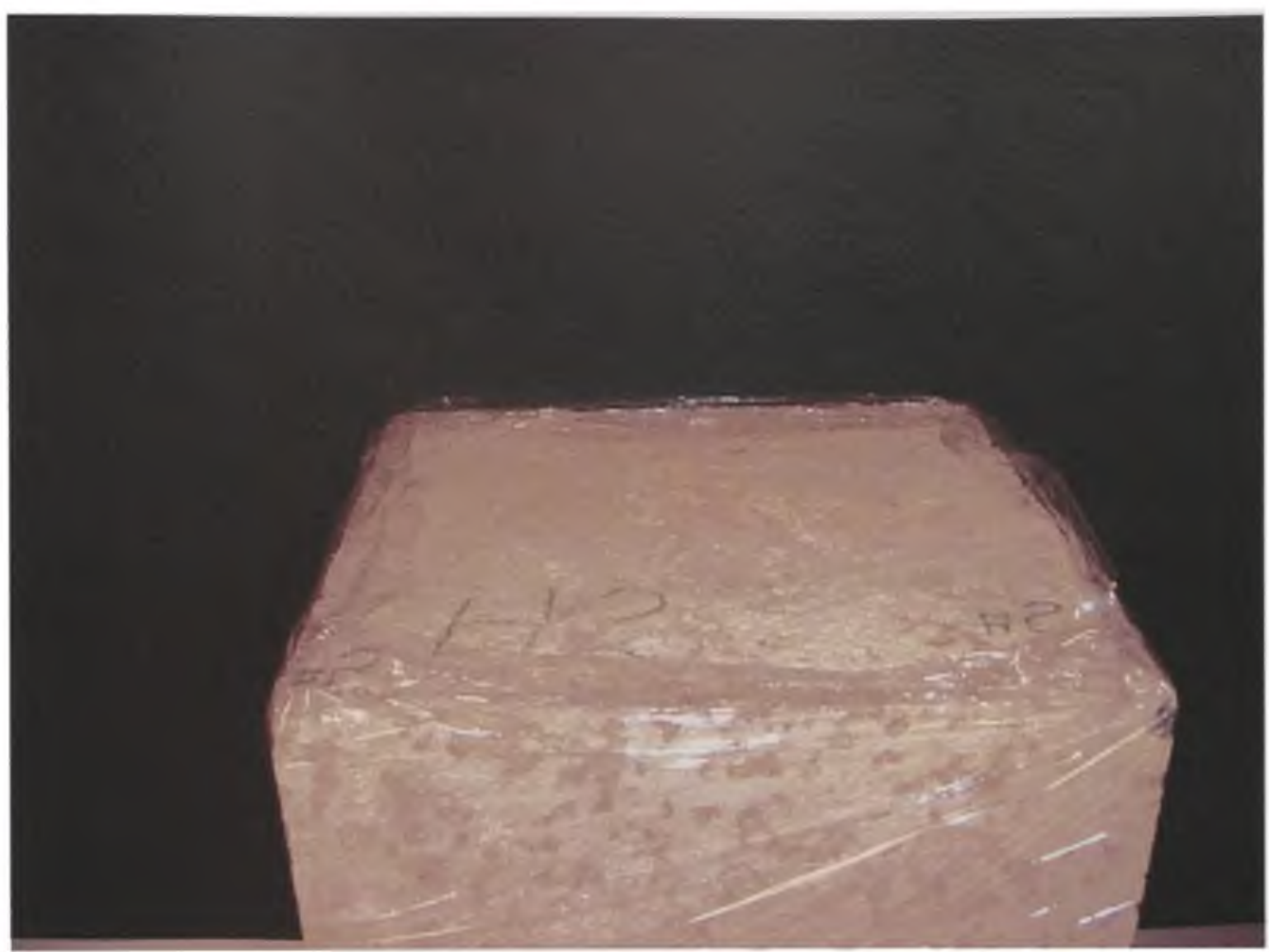

A.2 Plastic wrap applied around 4 faces of the cube, thus allowing flow in only one axis. 


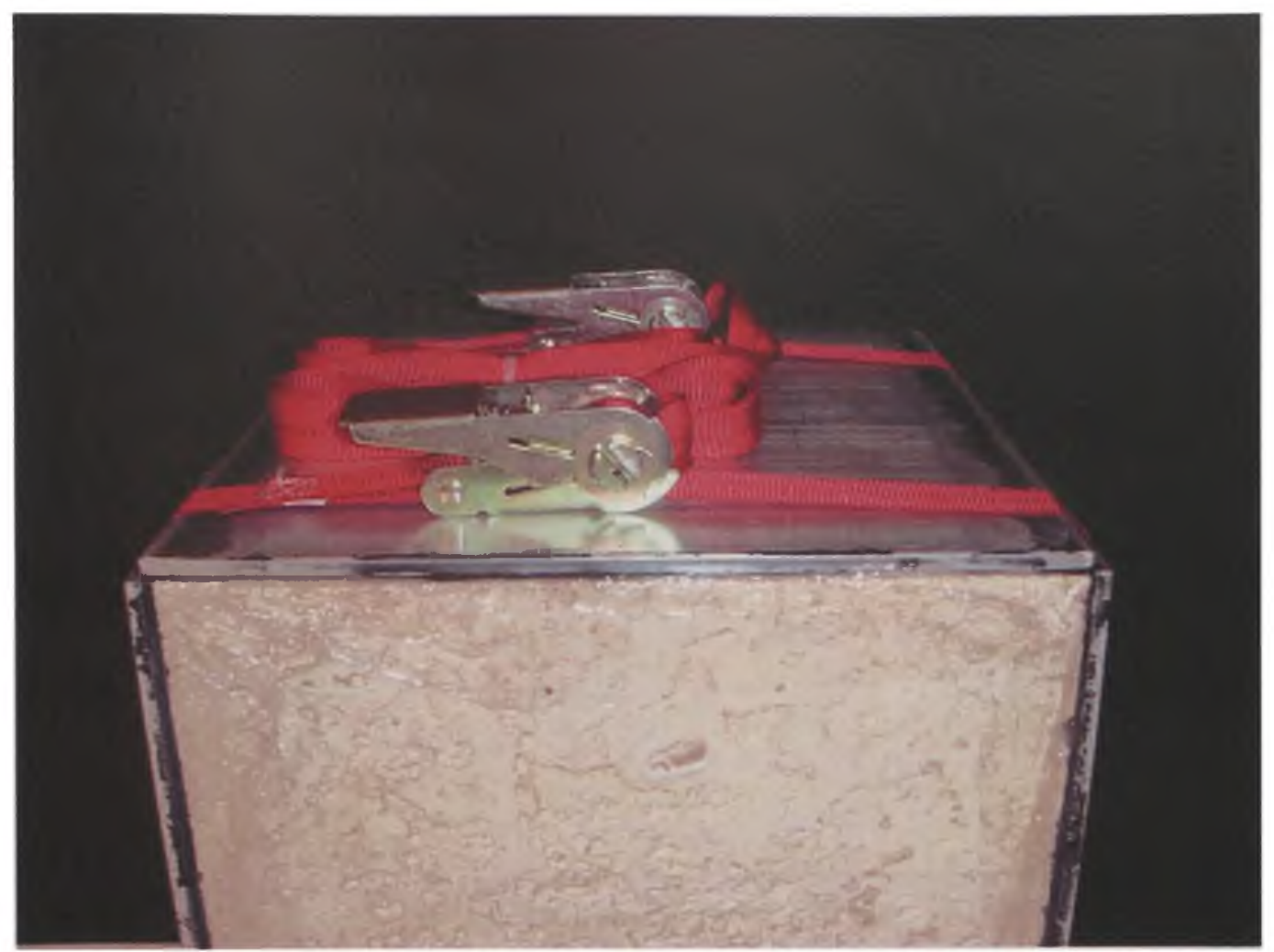

A.3 Closed cell neoprene rubber sheet forced against plastic wrap by ratcheting straps around aluminum plates. 


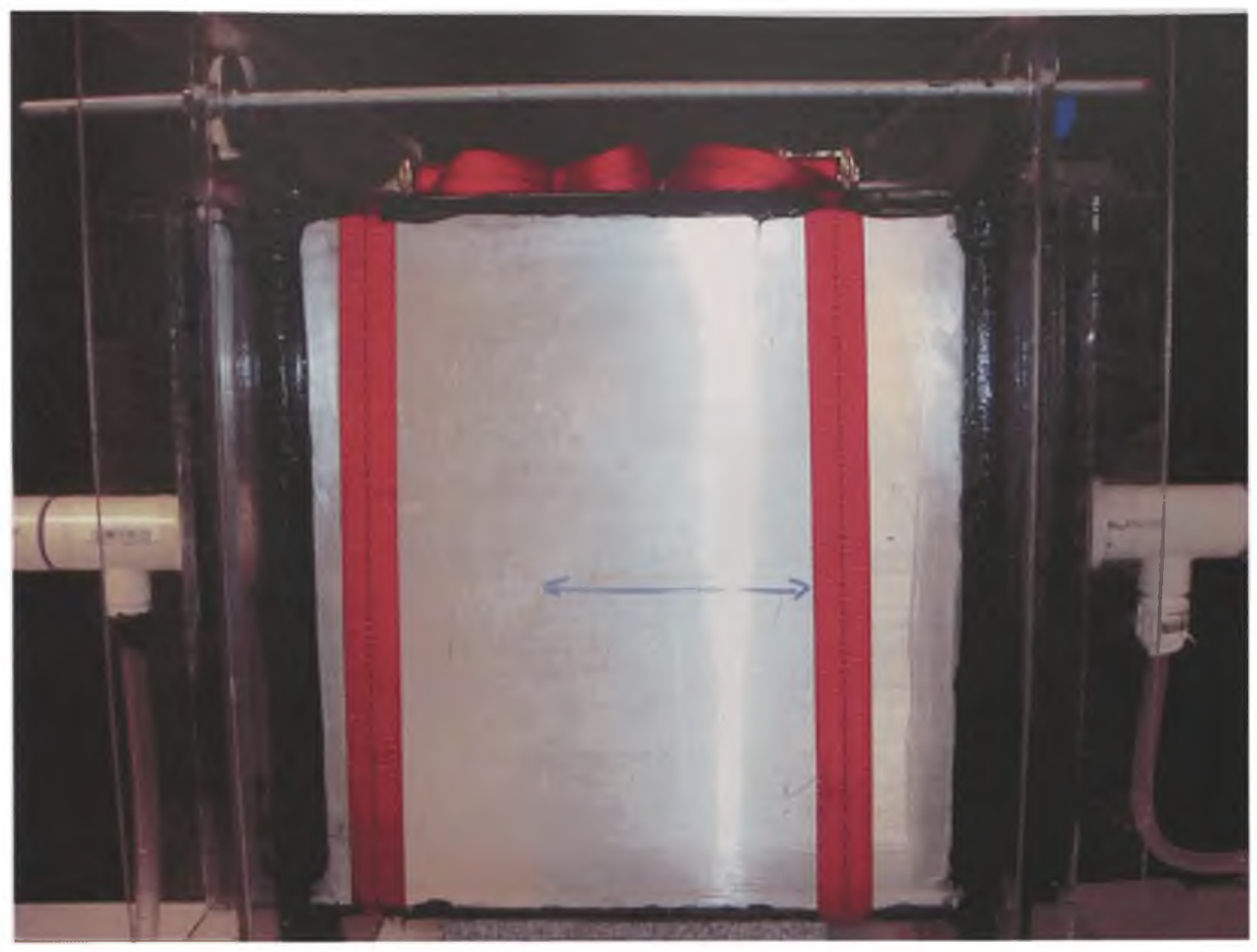

A.4 Front and back of permeameter bolted in position. All seams have been sealed with silicone. Arrow indicates direction of flow through the cube. 


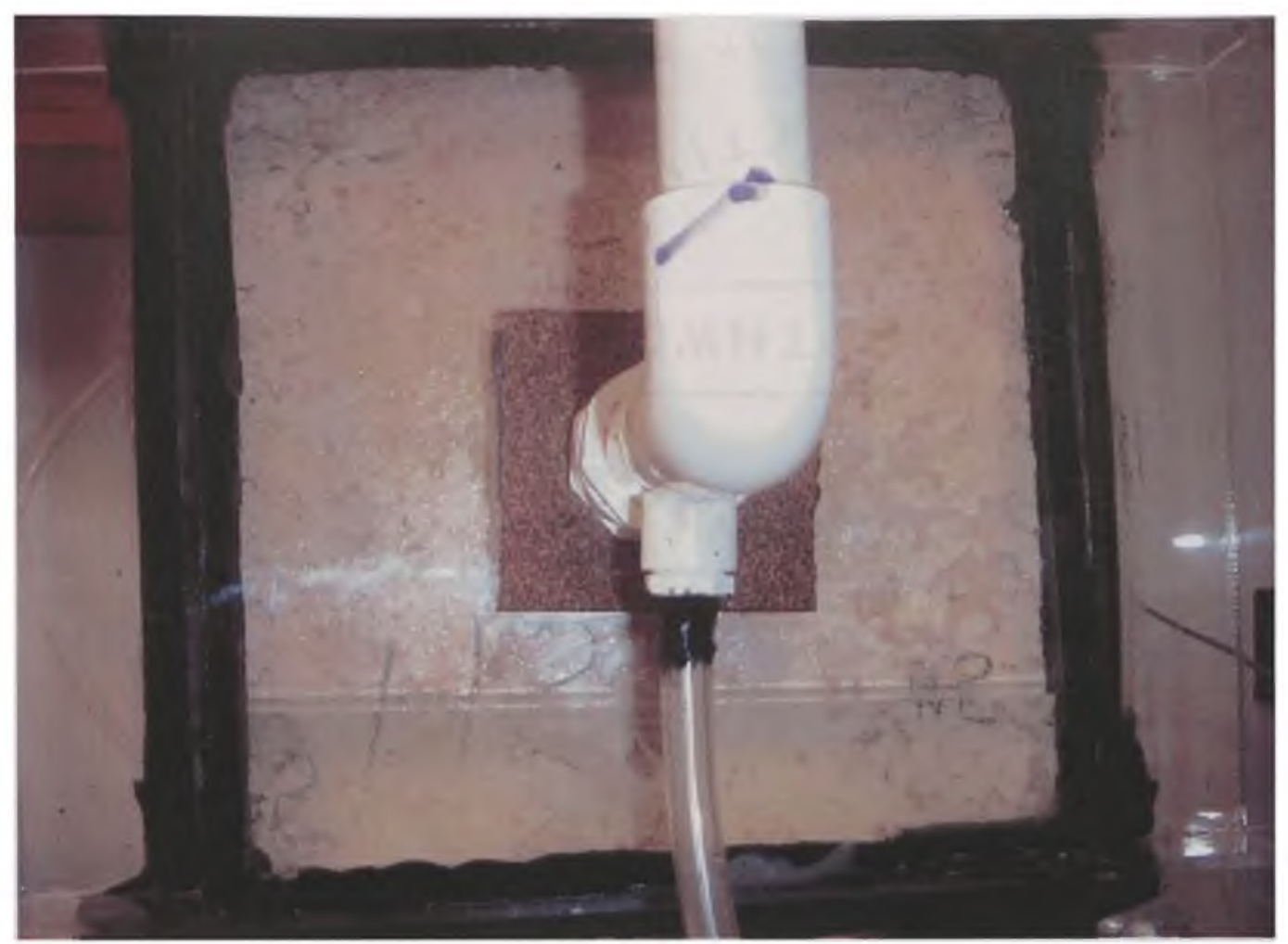

A.5 Permeameter being filled with water. 


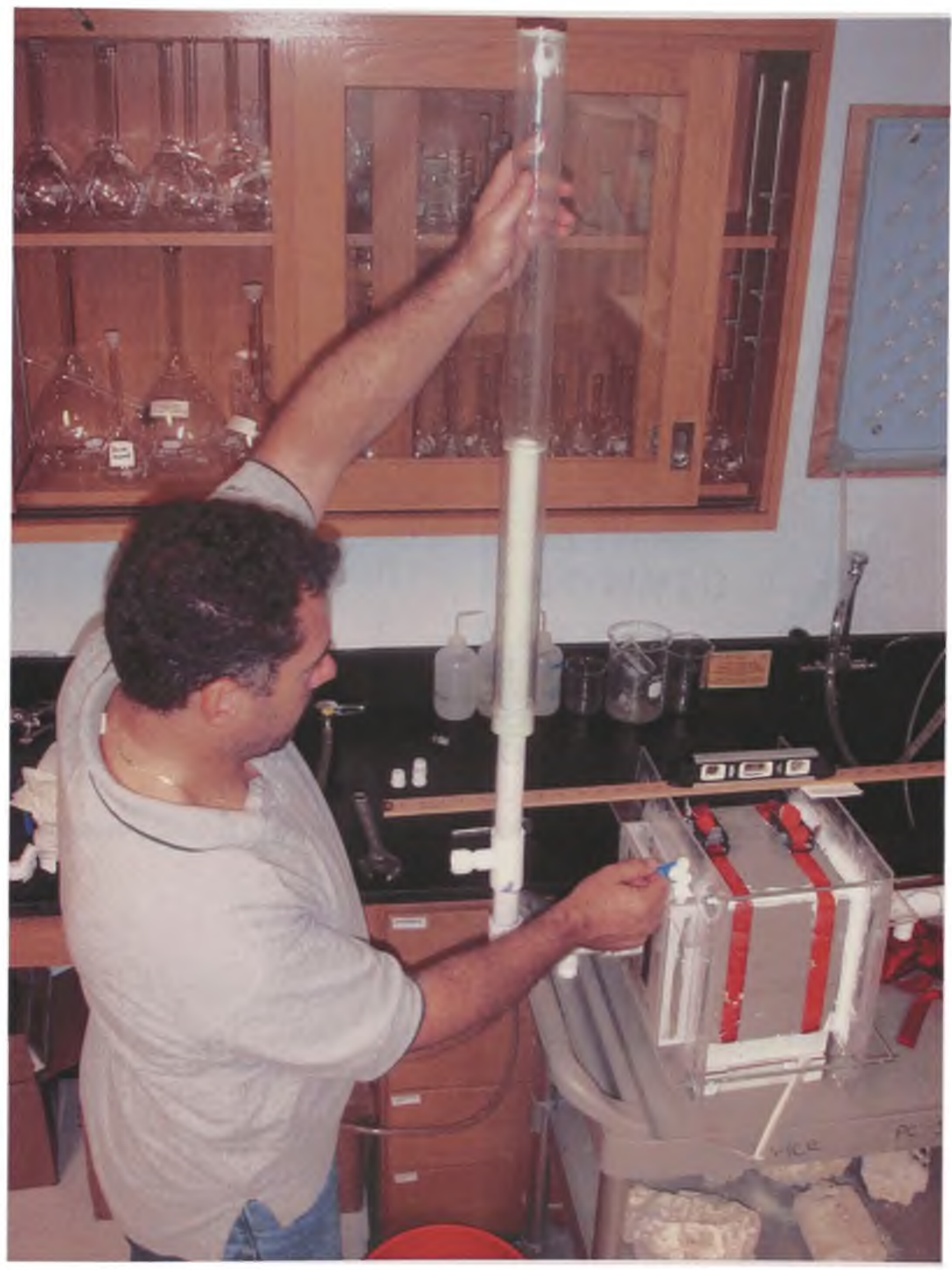

A.6 Permeameter being vacuumed to insure cube is saturated. Air drawn from the cube is vented through the valve on upper right side of outflow side. 


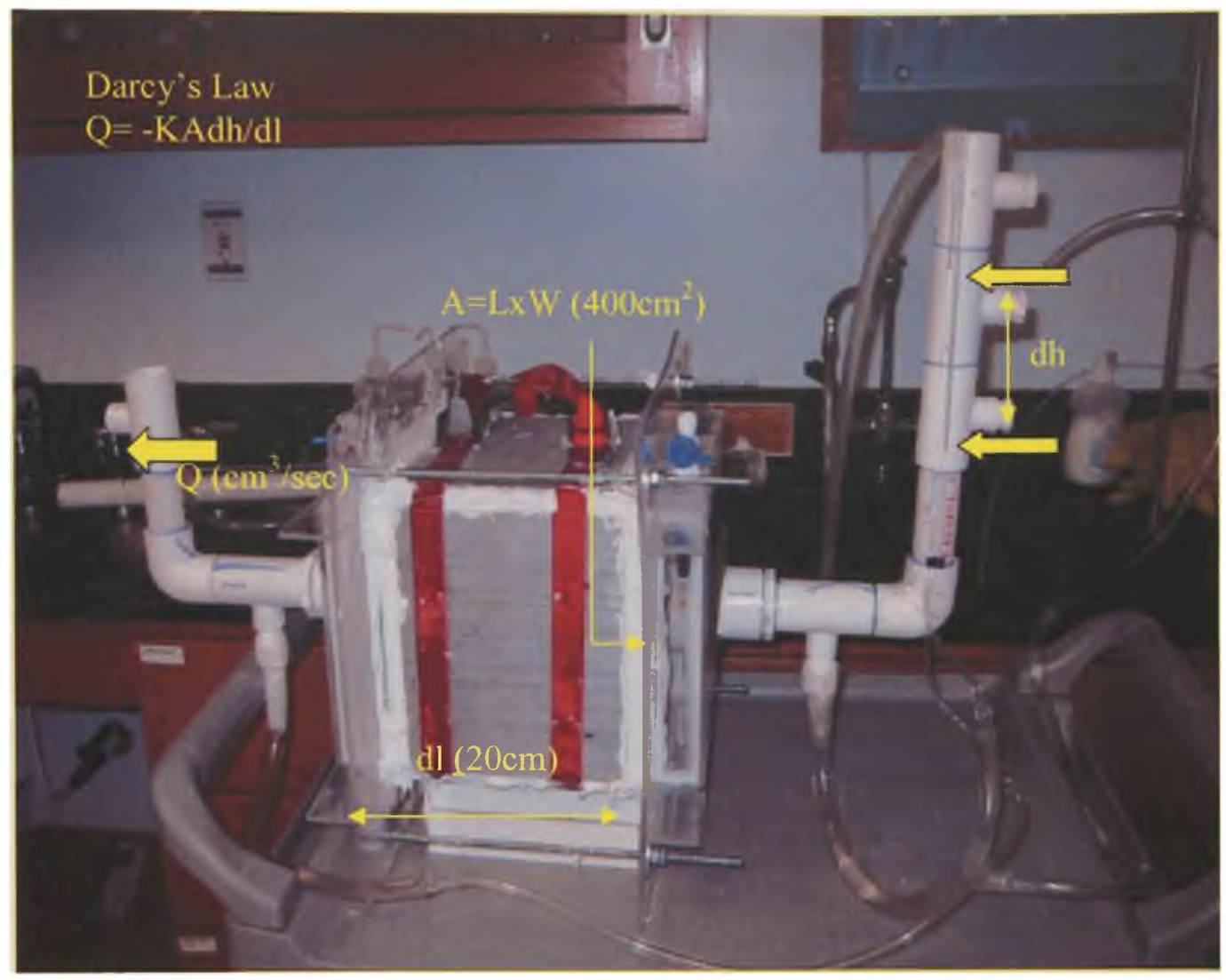

A.7 Permeameter labeled to show where each variable for Darcy's law $(\mathrm{Q}=-\mathrm{KA}(\mathrm{dh} / \mathrm{dl}))$ is obtained. 


\section{APPENDIX B}

Permeameter plots from each axis of each $20 \mathrm{~cm}$ and $30 \mathrm{~cm}$

Key Largo Limestone cube 

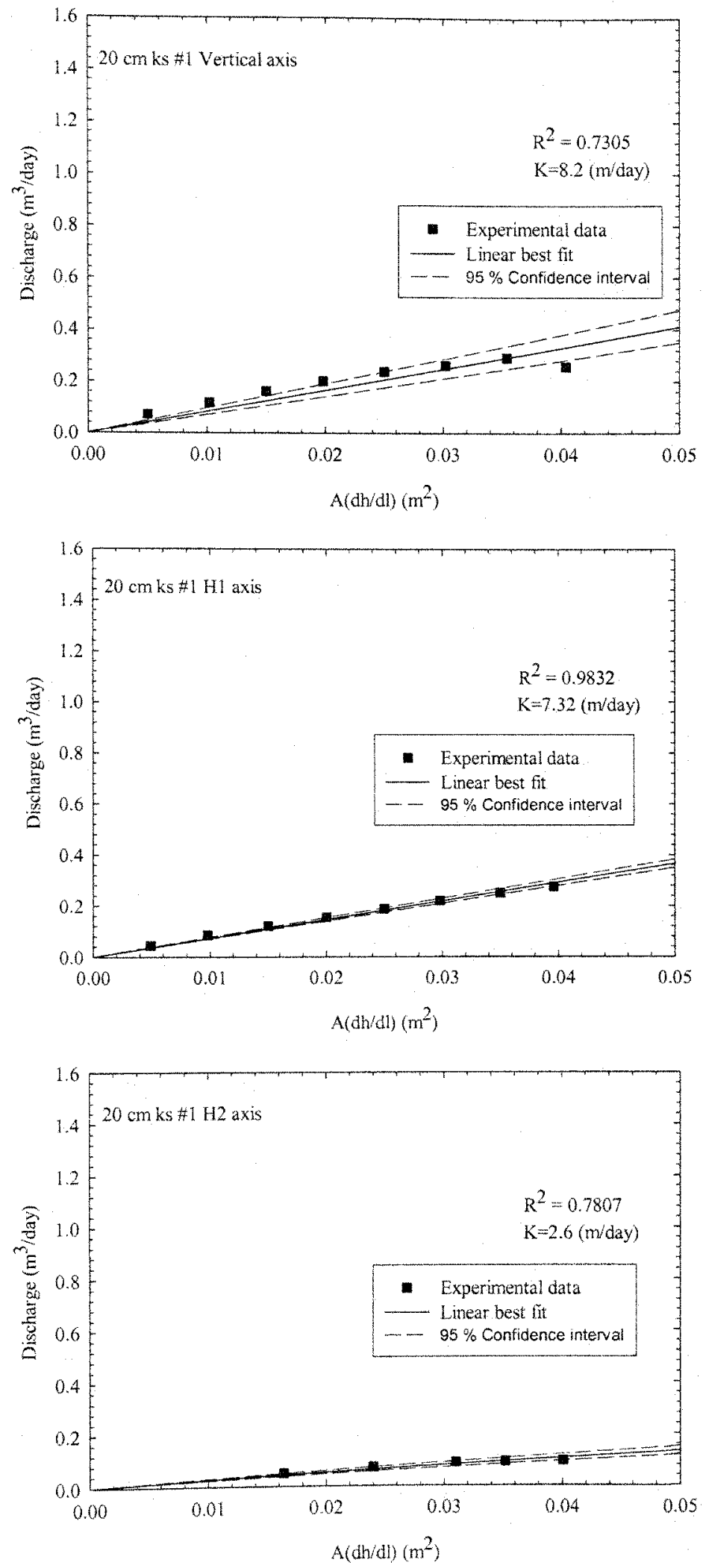

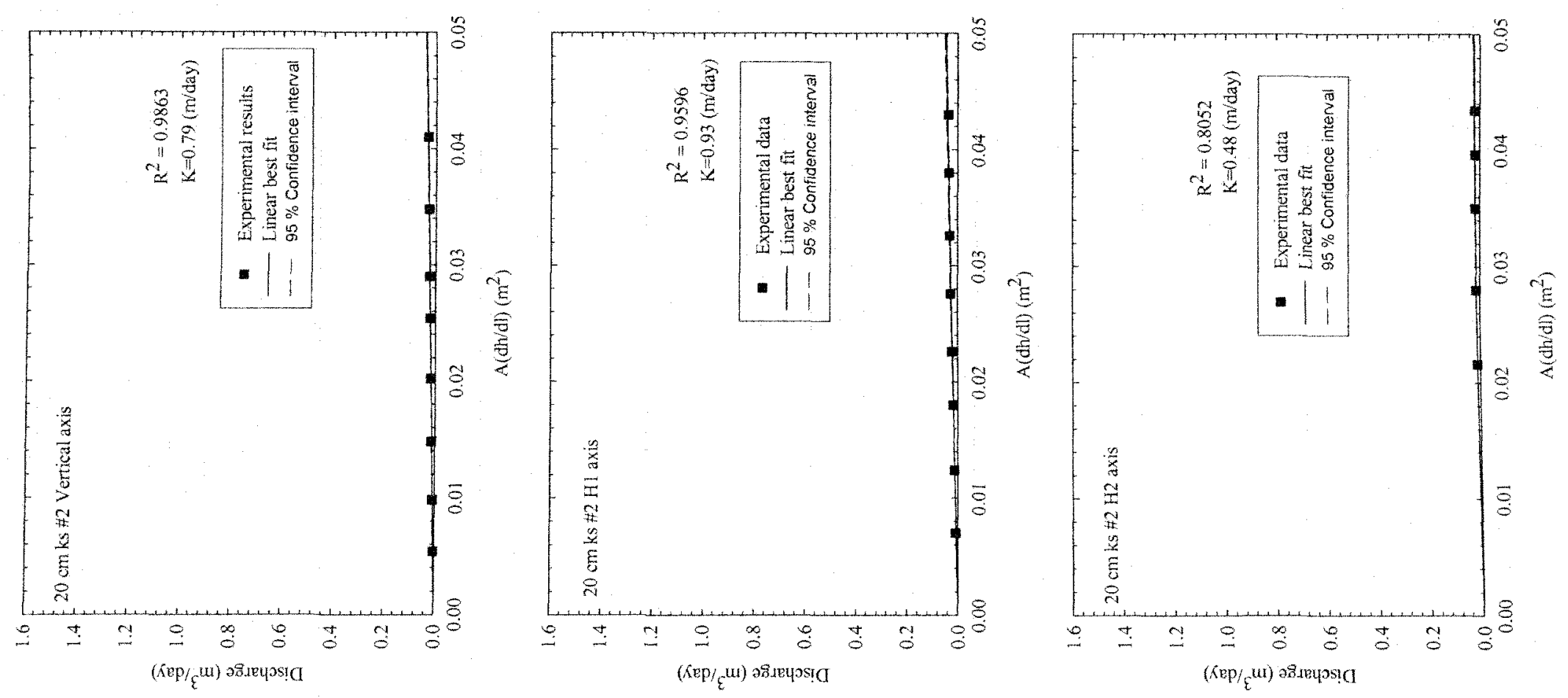

2 

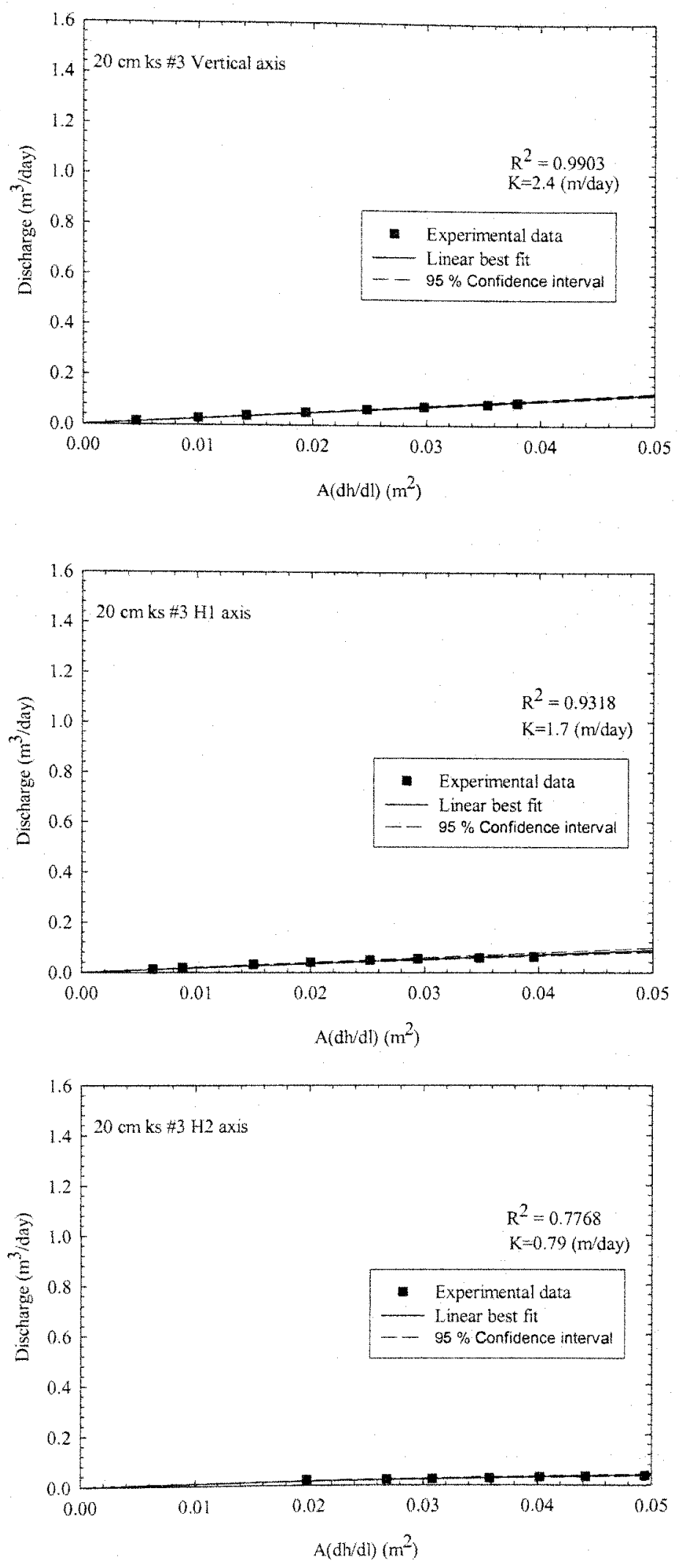

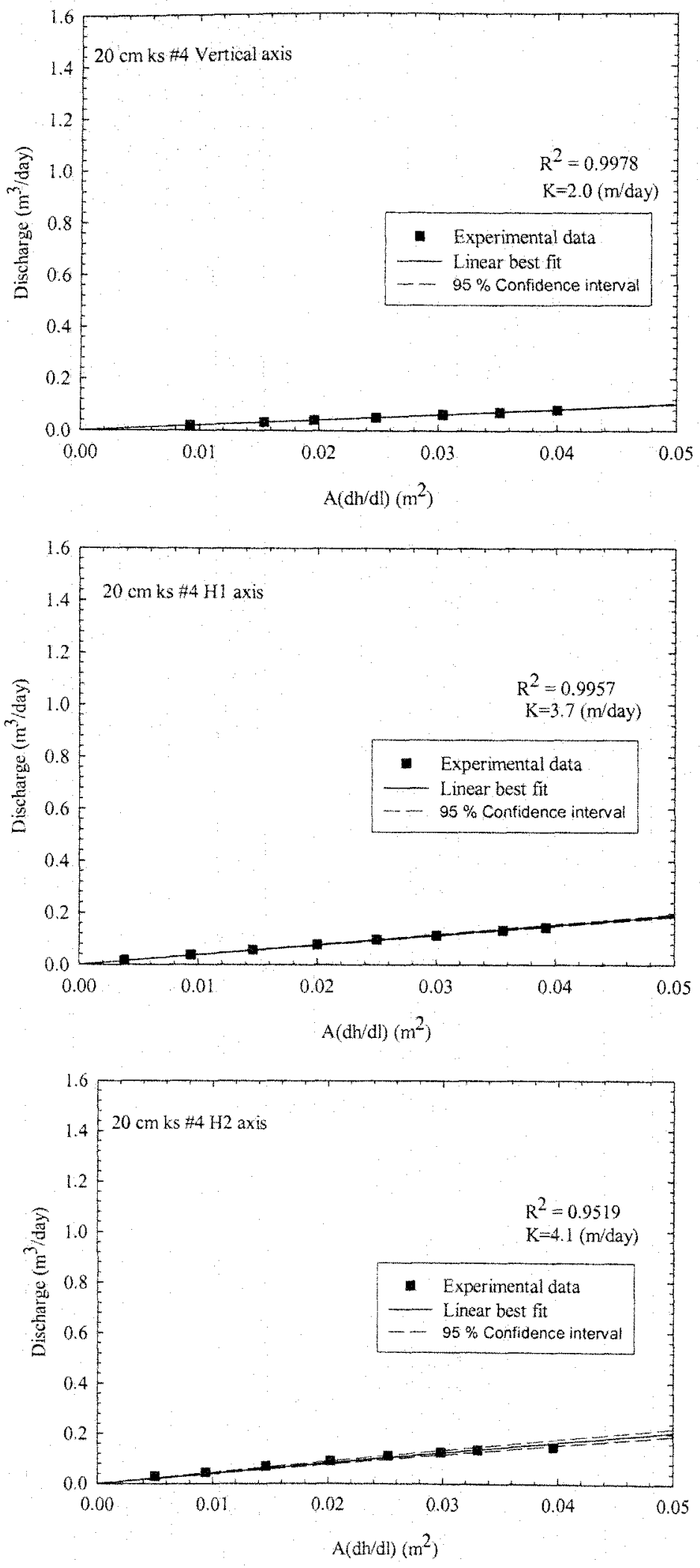

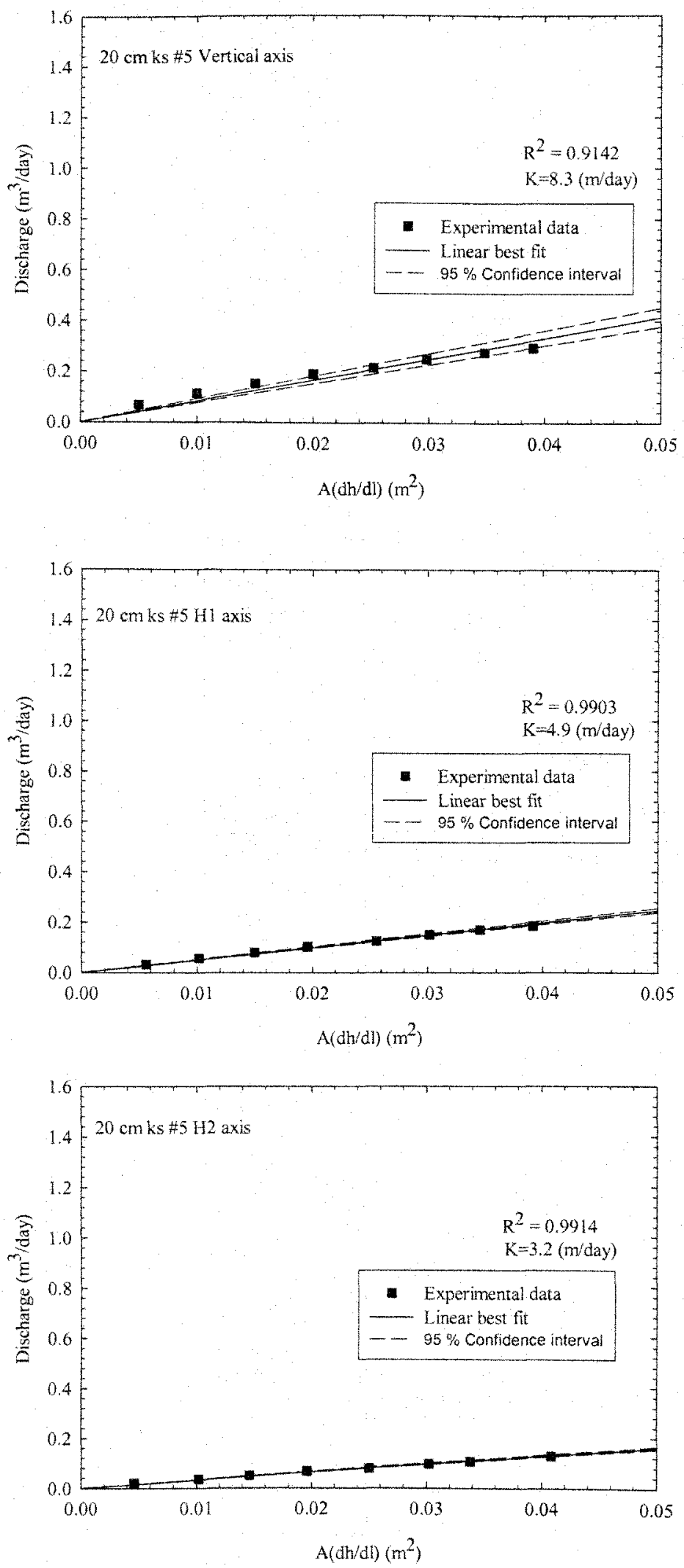

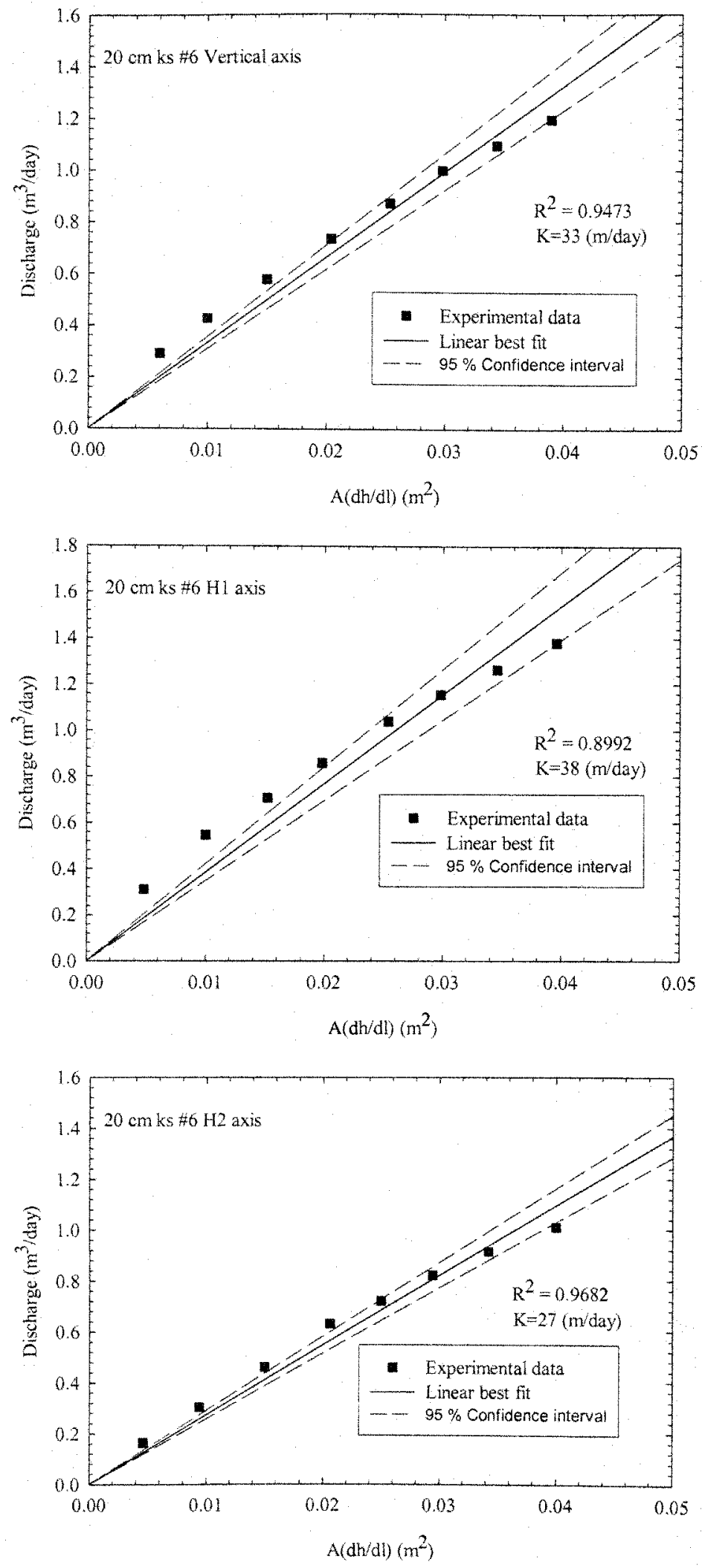

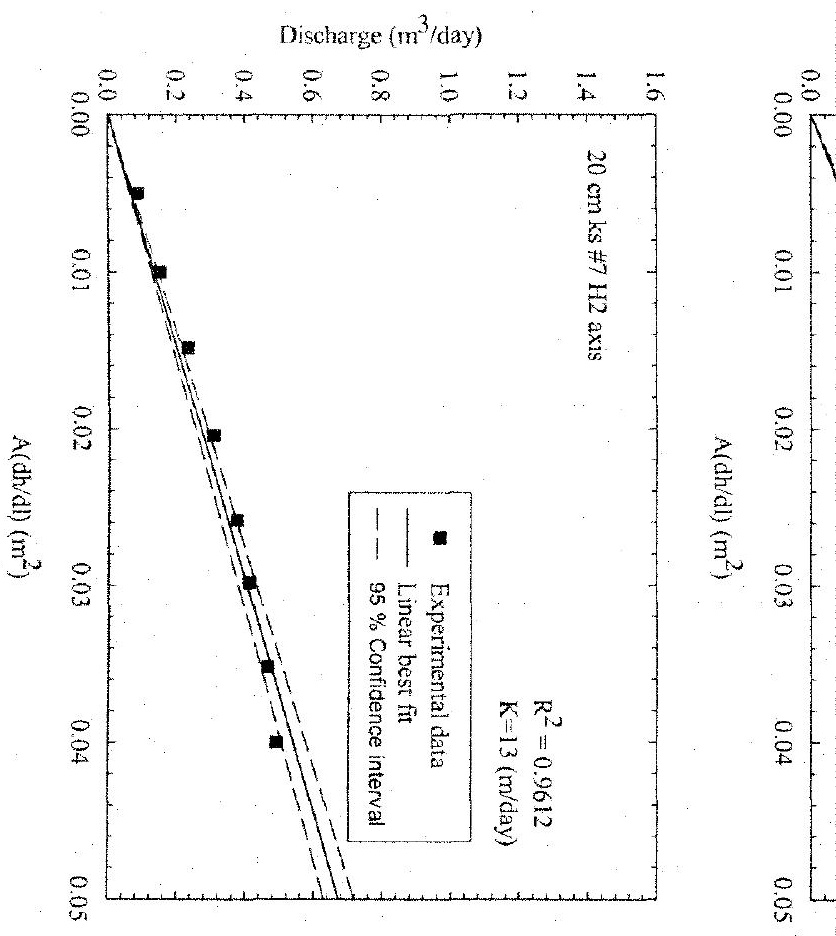

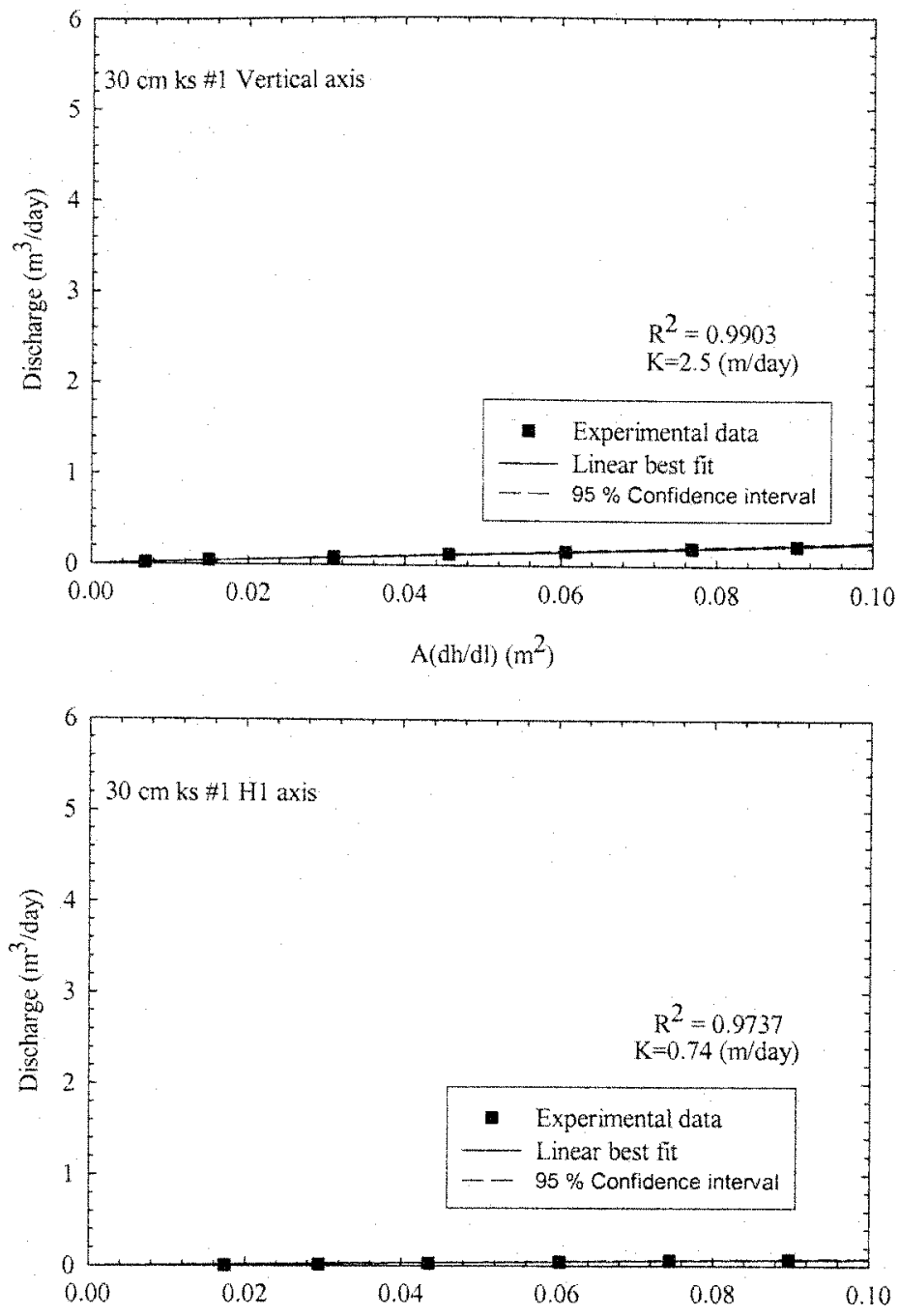

$\mathrm{A}(\mathrm{d} / \mathrm{dl})\left(\mathrm{m}^{2}\right)$

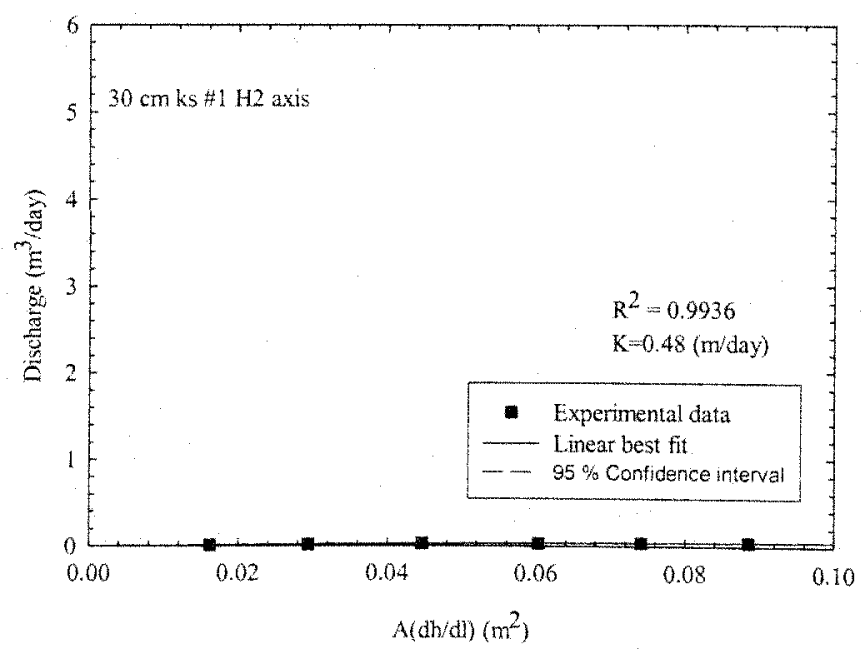




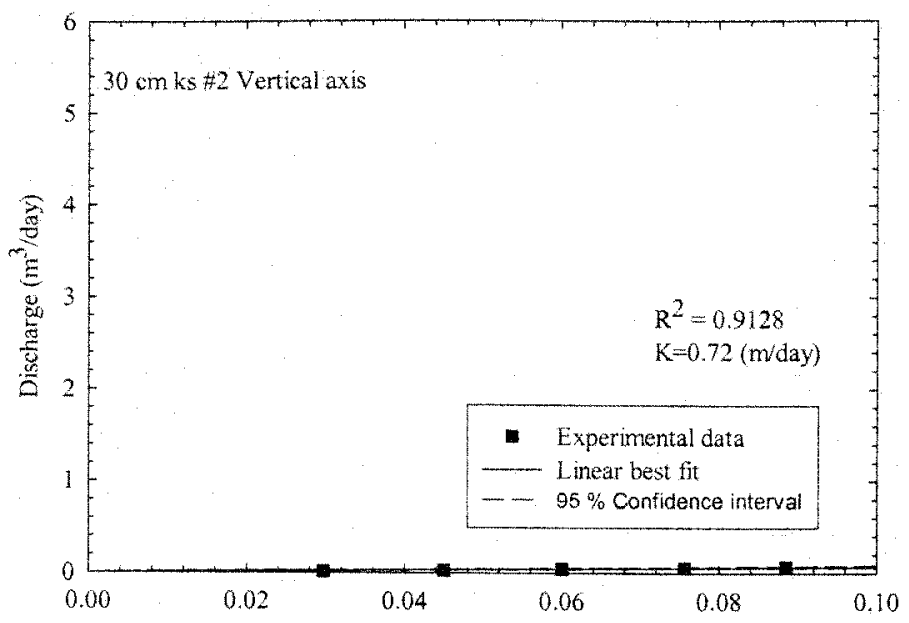

$\mathrm{A}(\mathrm{dh} / \mathrm{dl})\left(\mathrm{m}^{2}\right)$
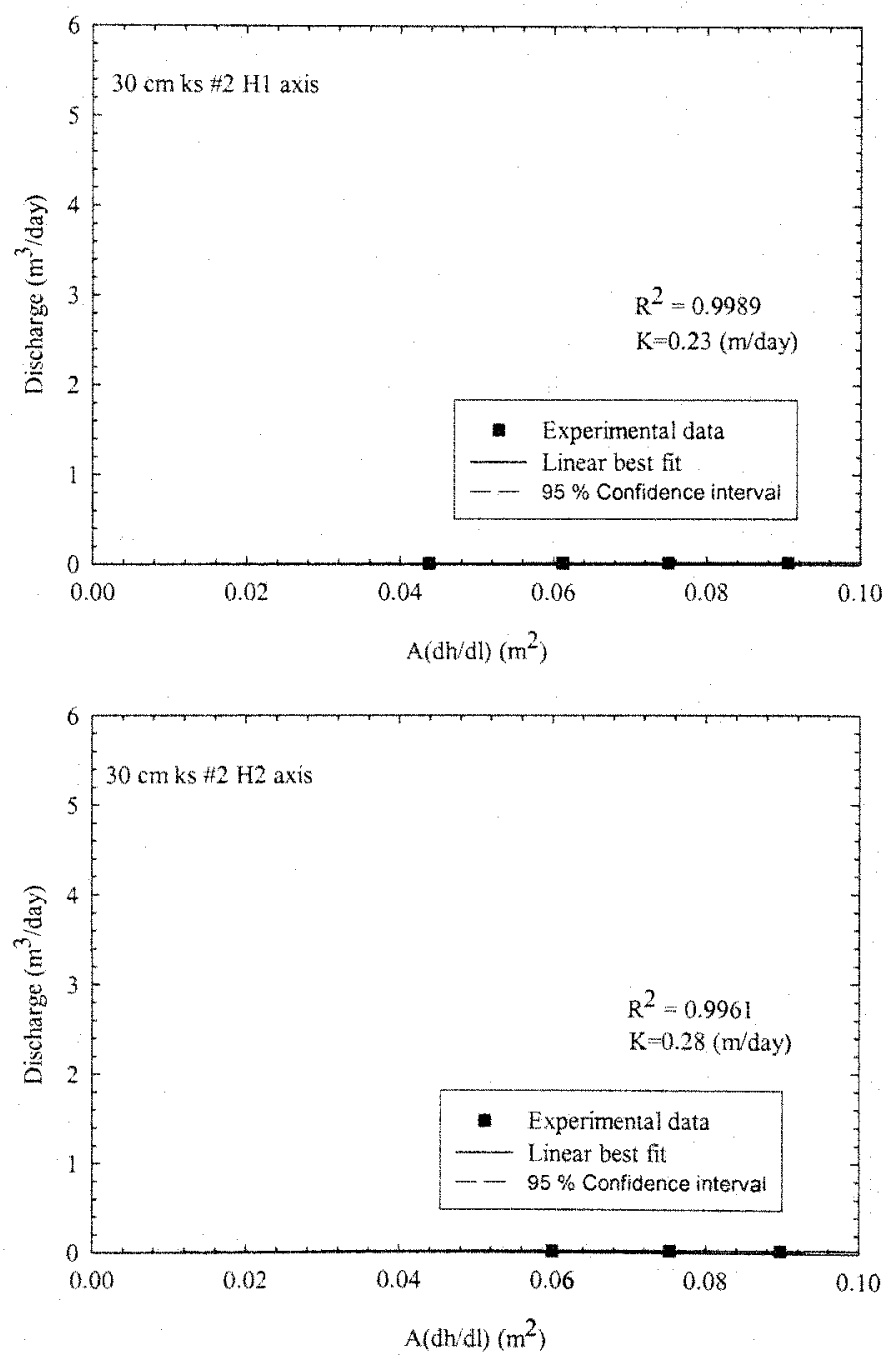

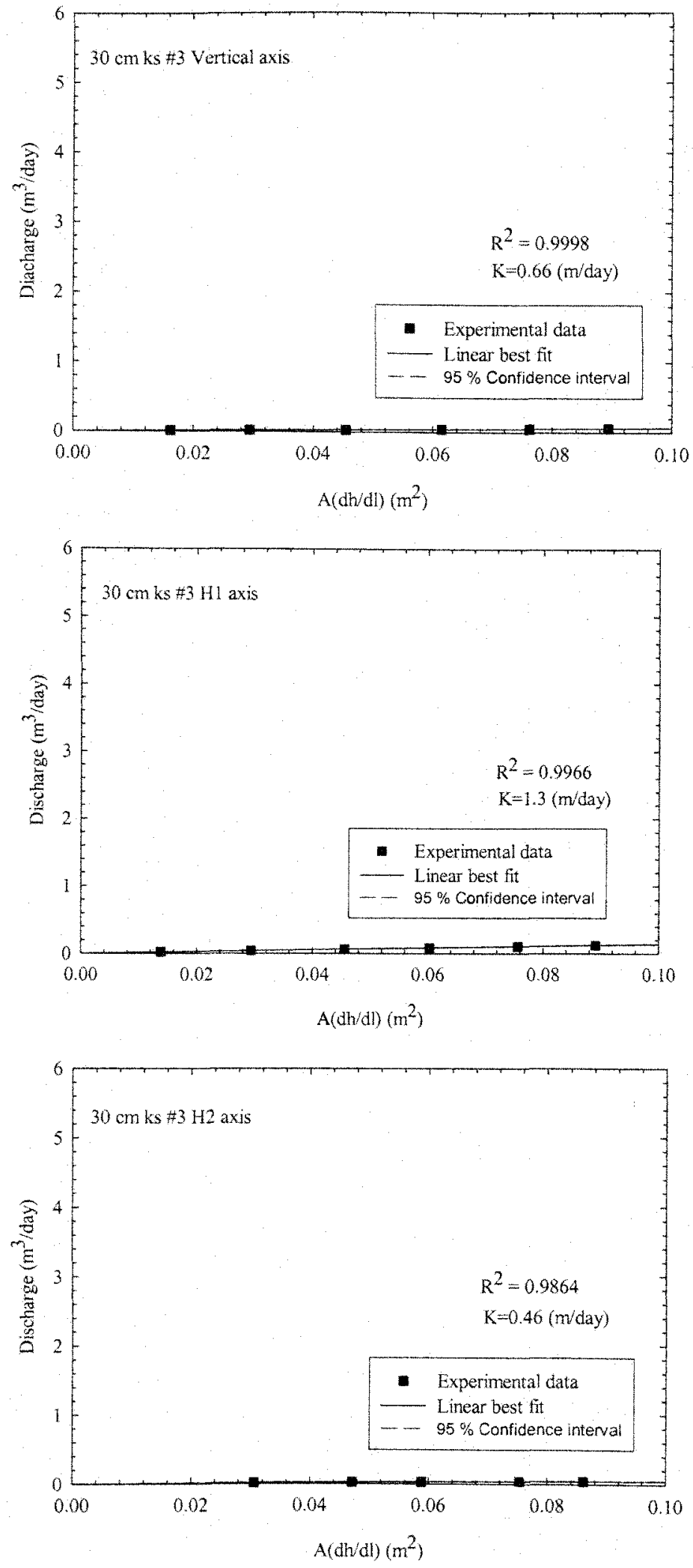

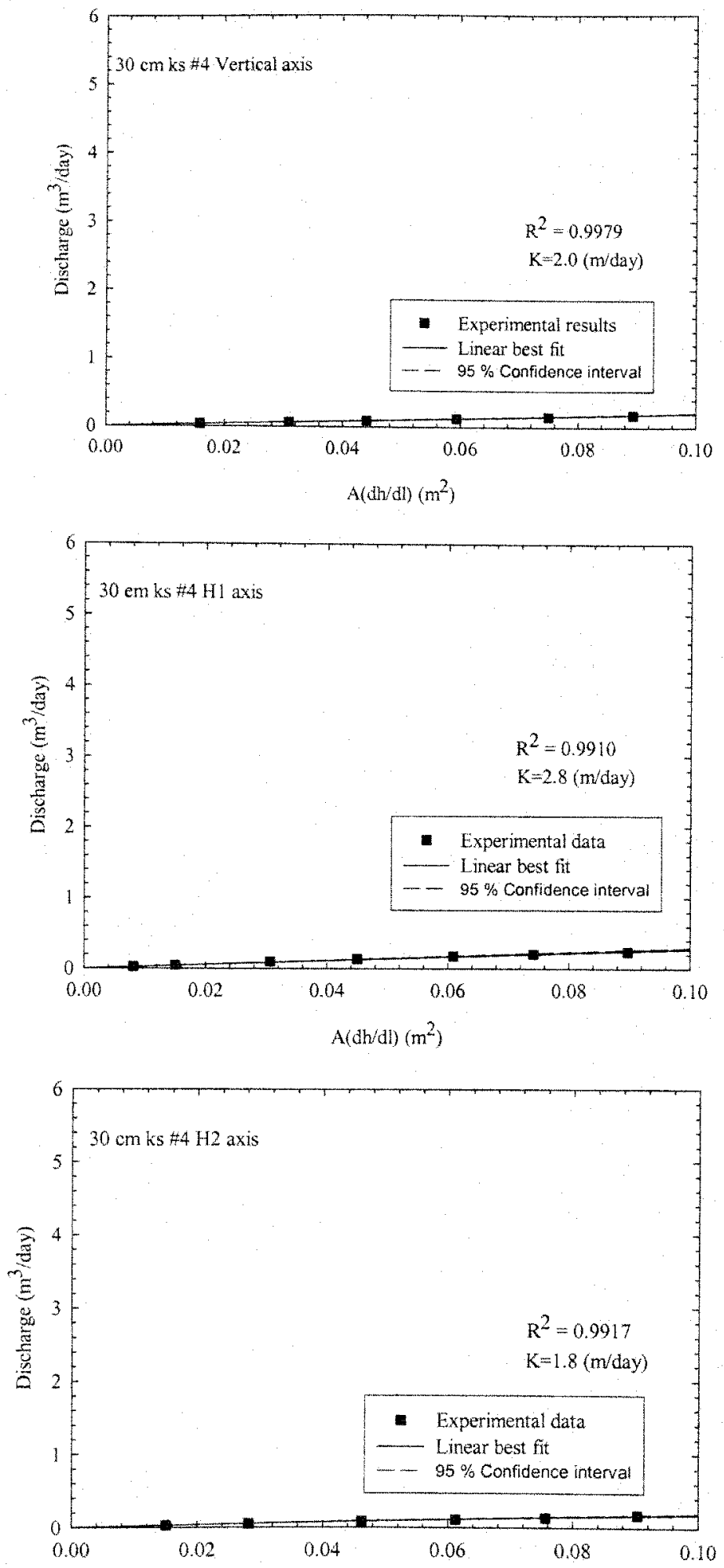

$\mathrm{A}(\mathrm{dh} / \mathrm{dl})\left(\mathrm{m}^{2}\right)$ 

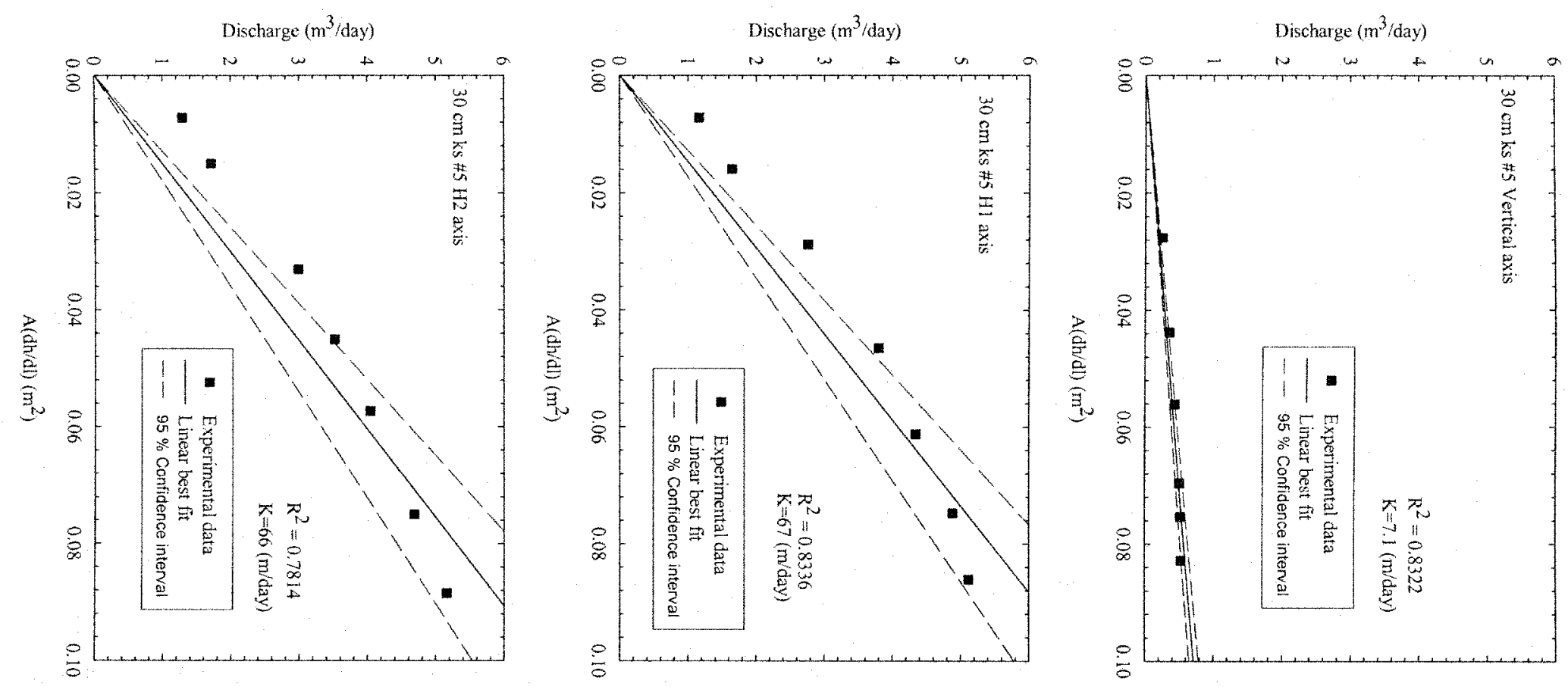

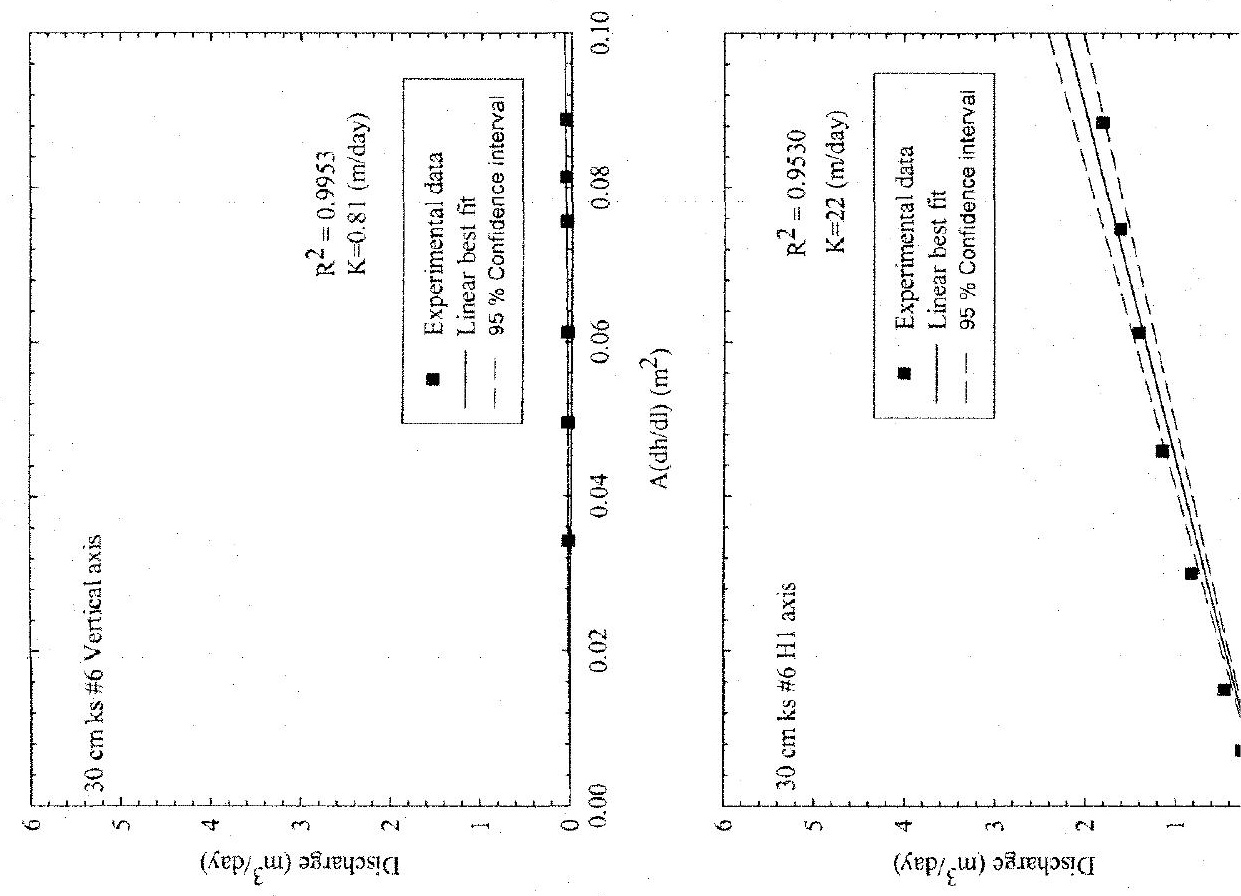


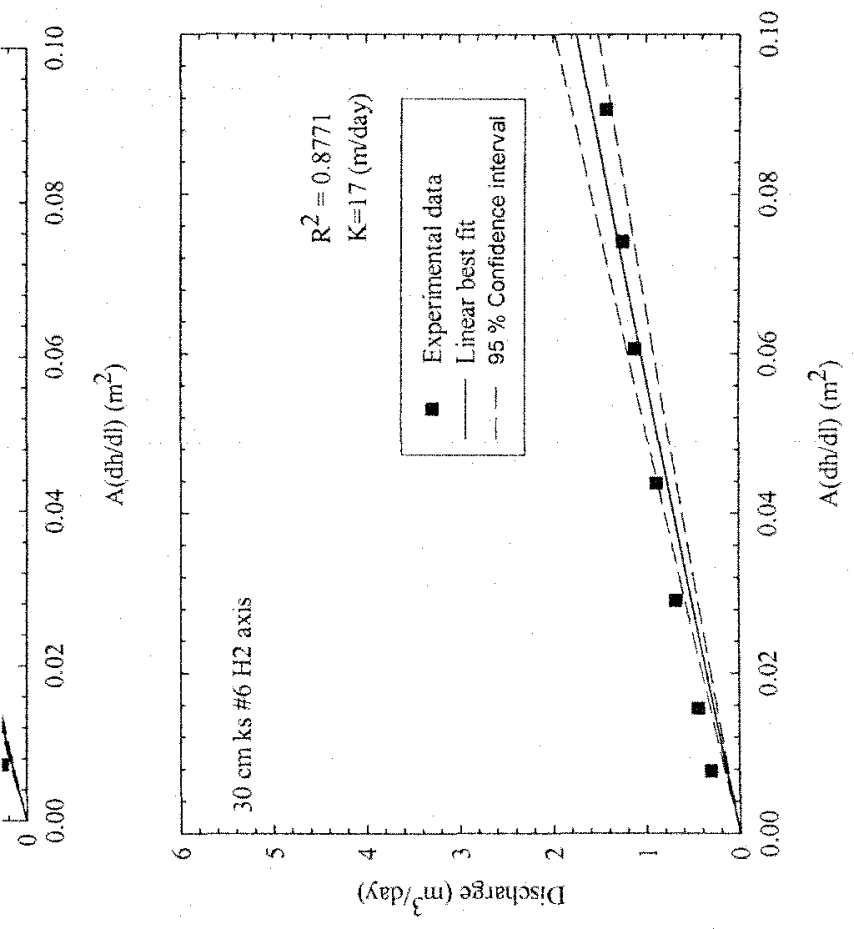

$\stackrel{\varrho}{\exists}$ 
APPENDIX C

Slug tests matched curves 

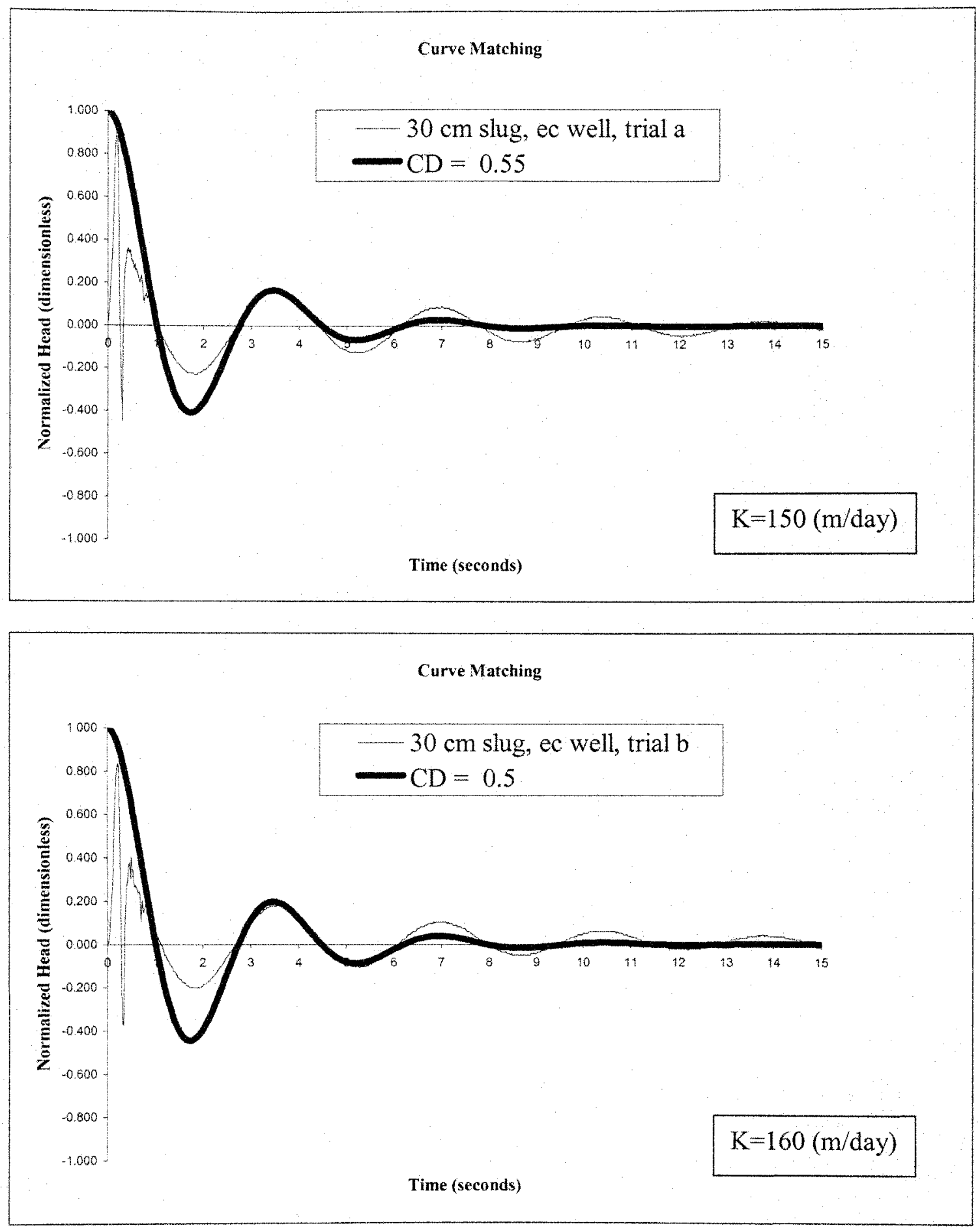

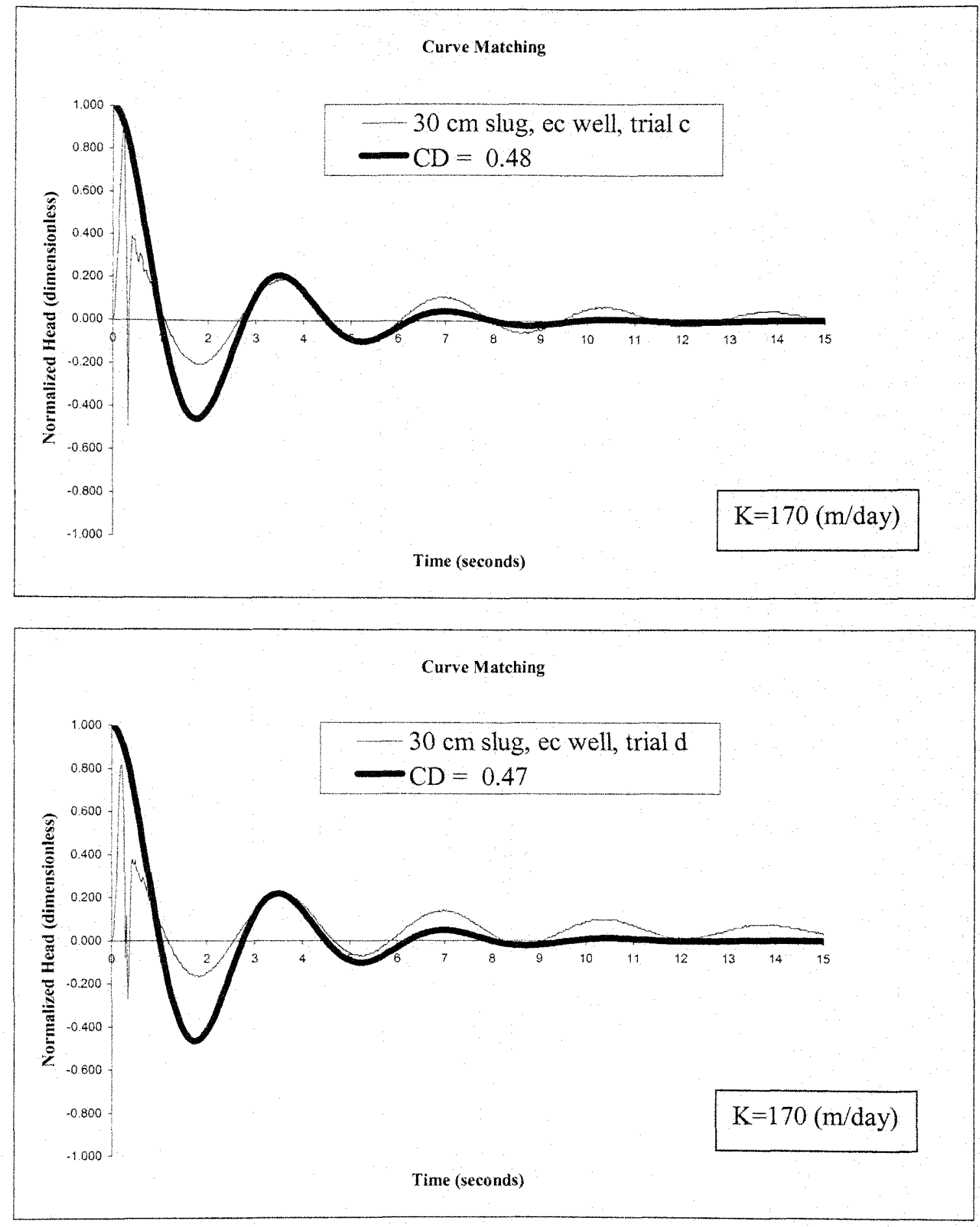

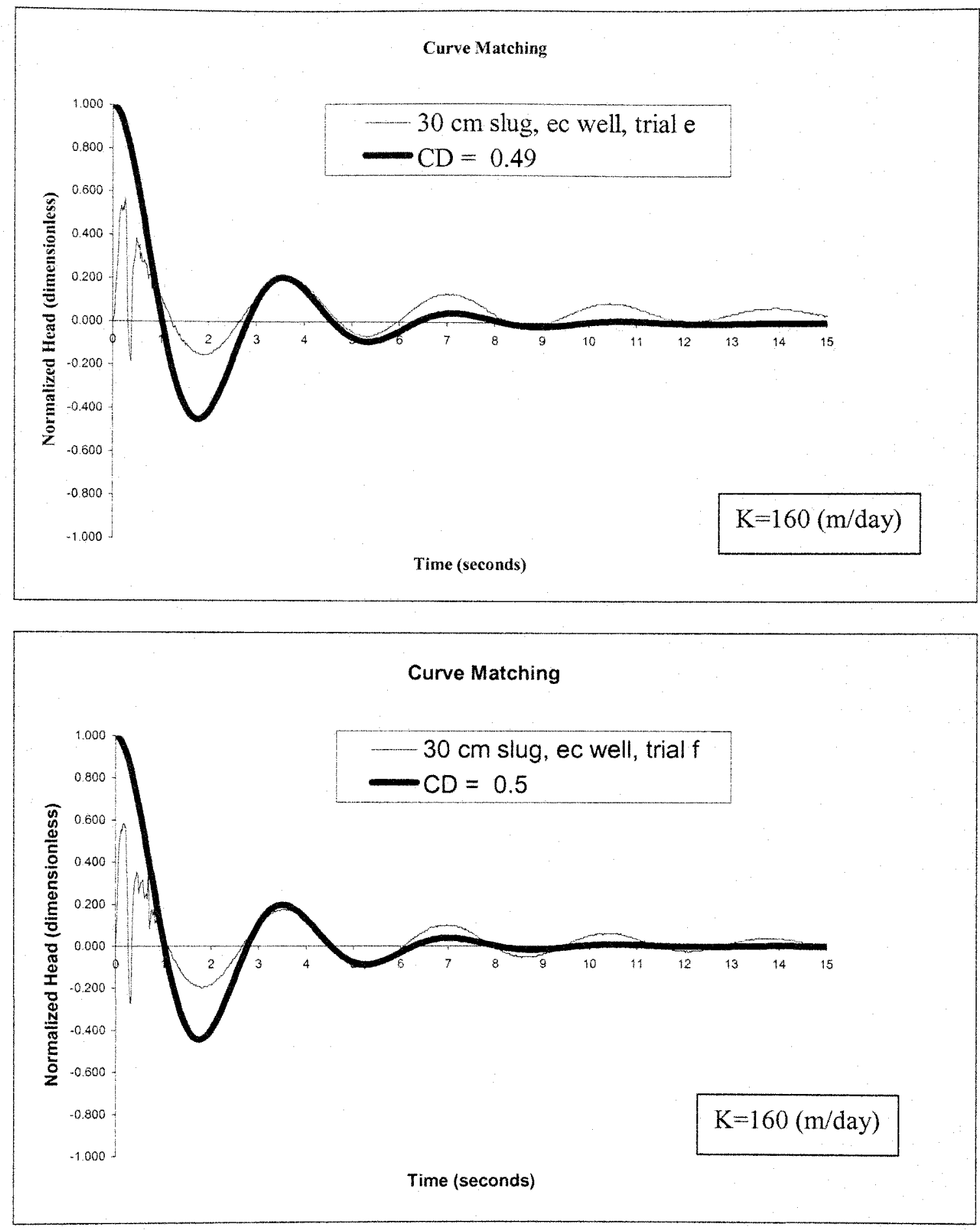


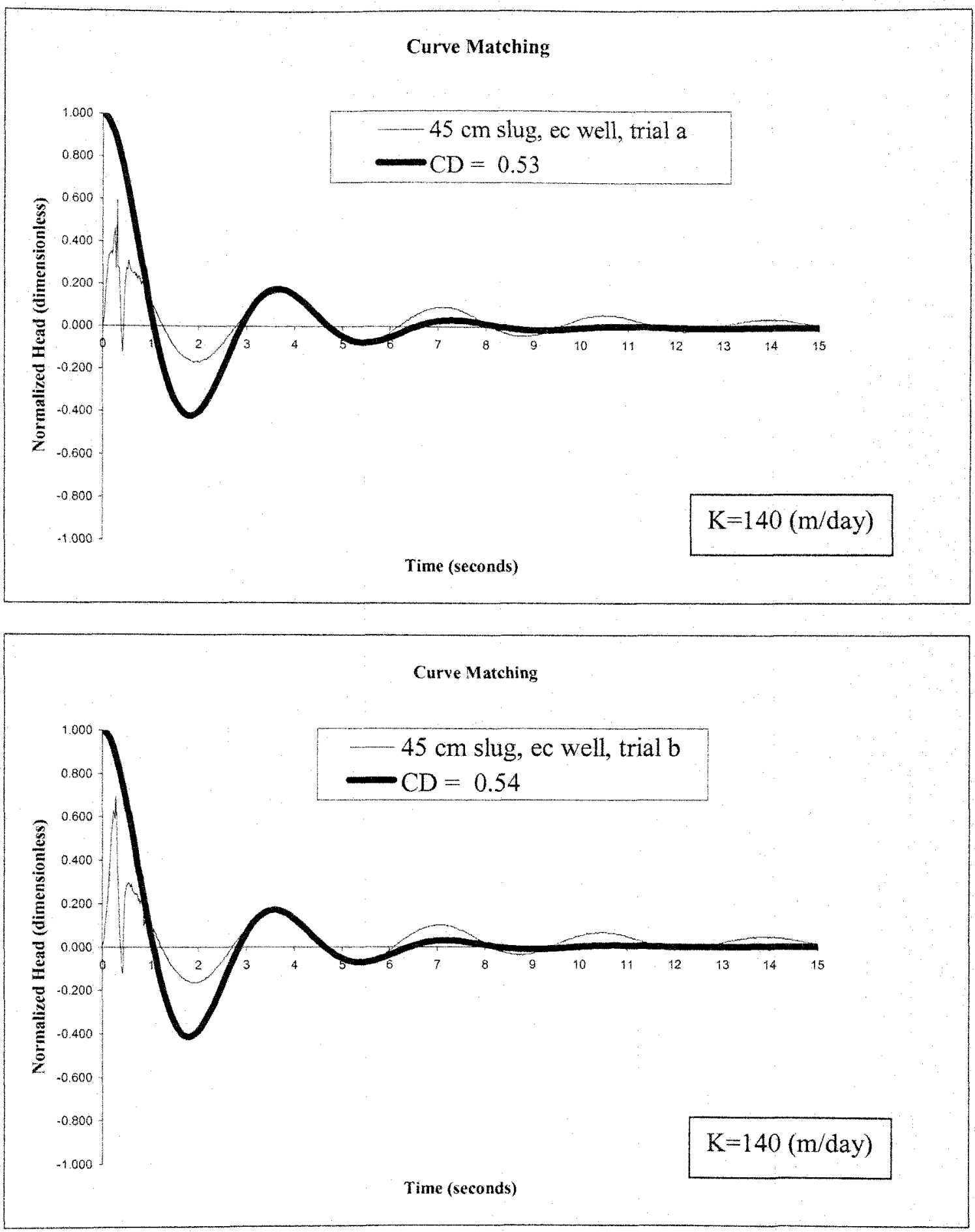



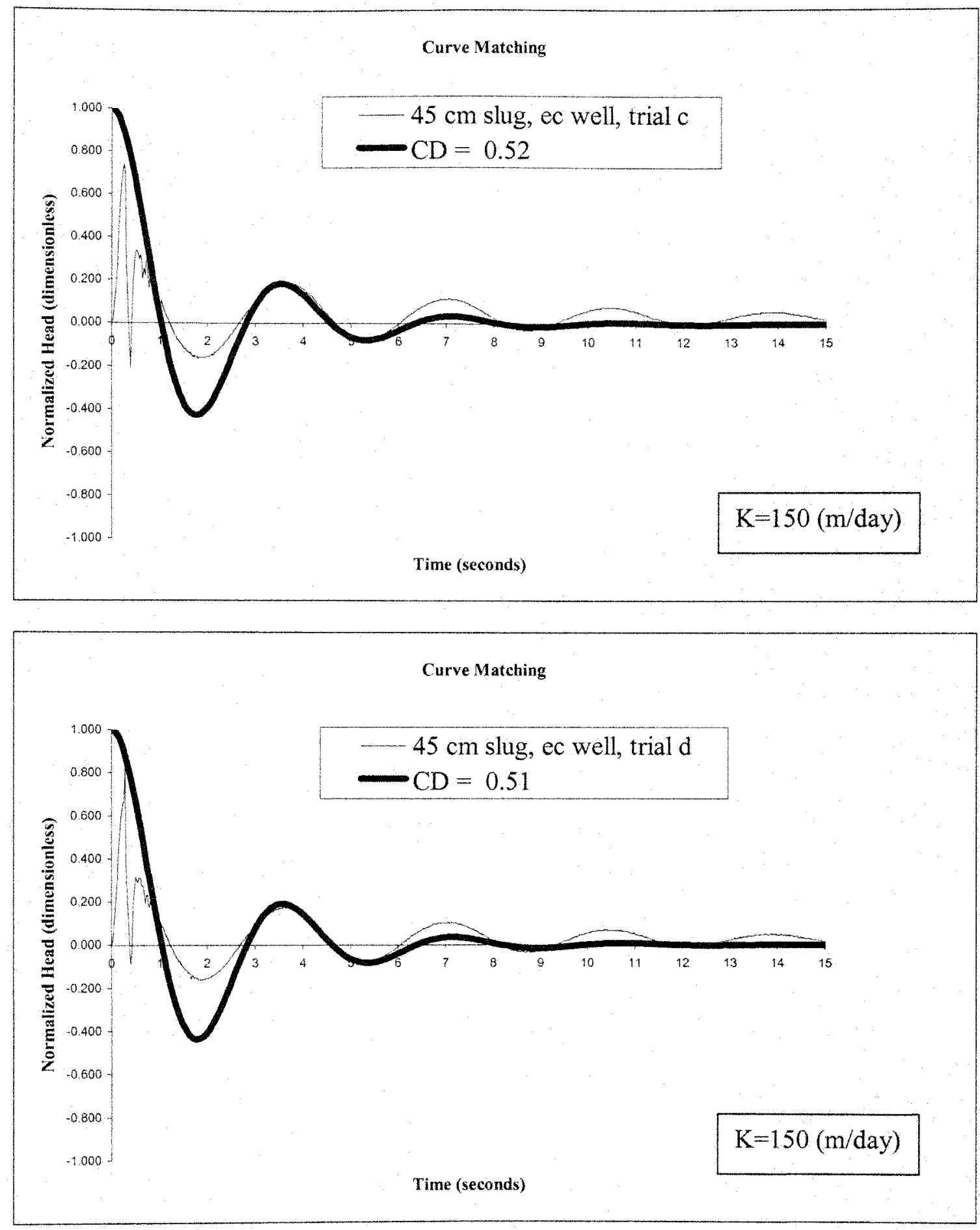


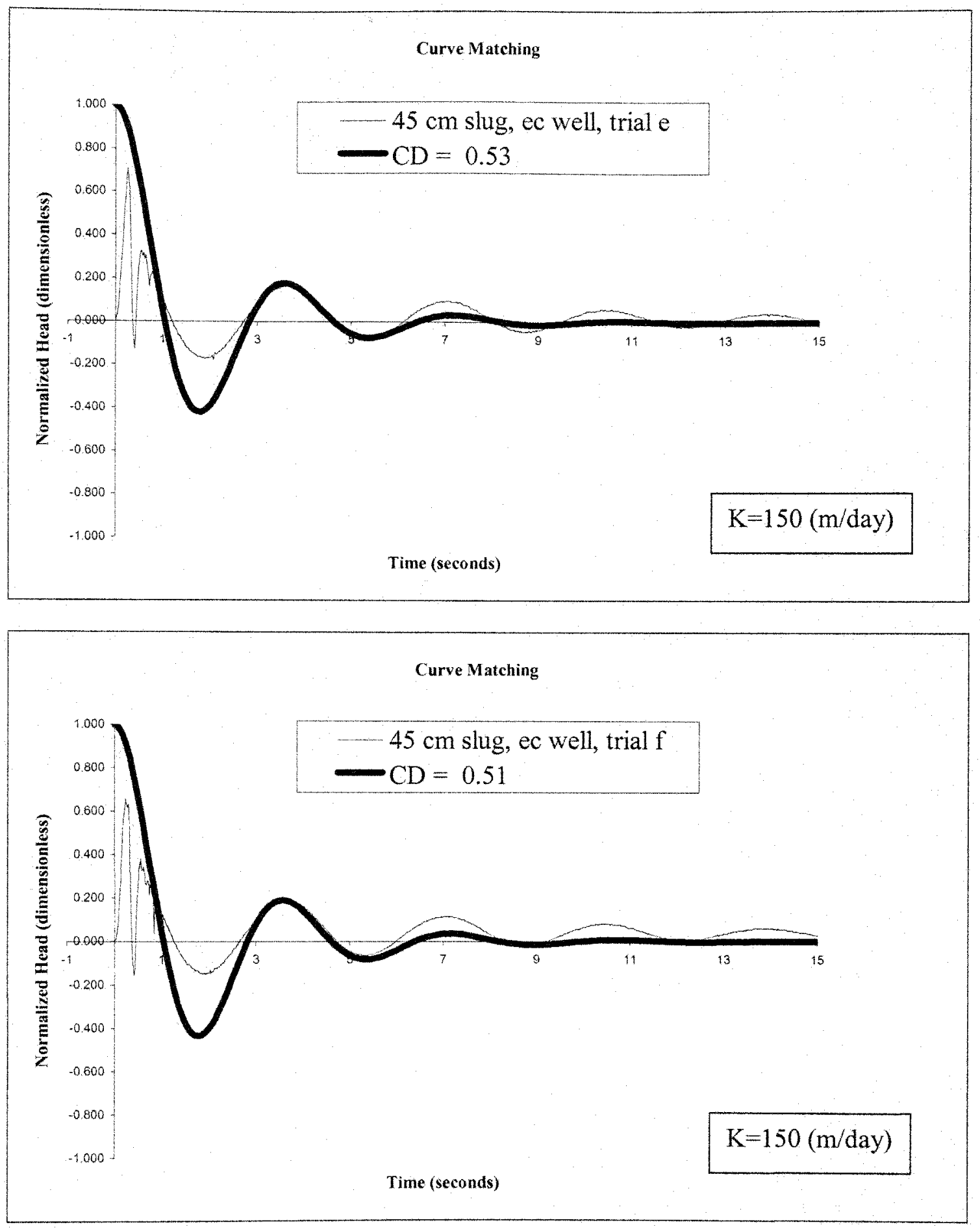



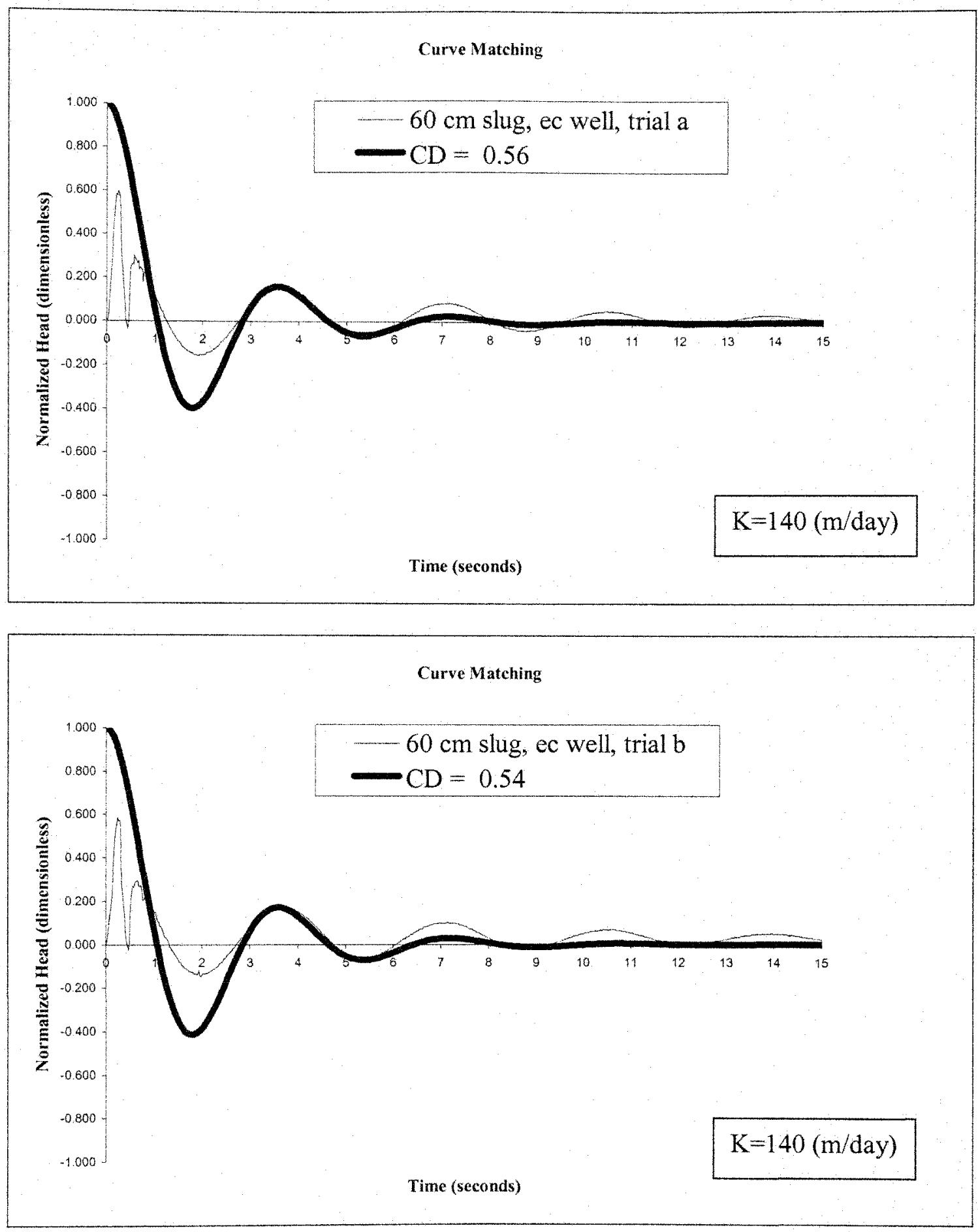


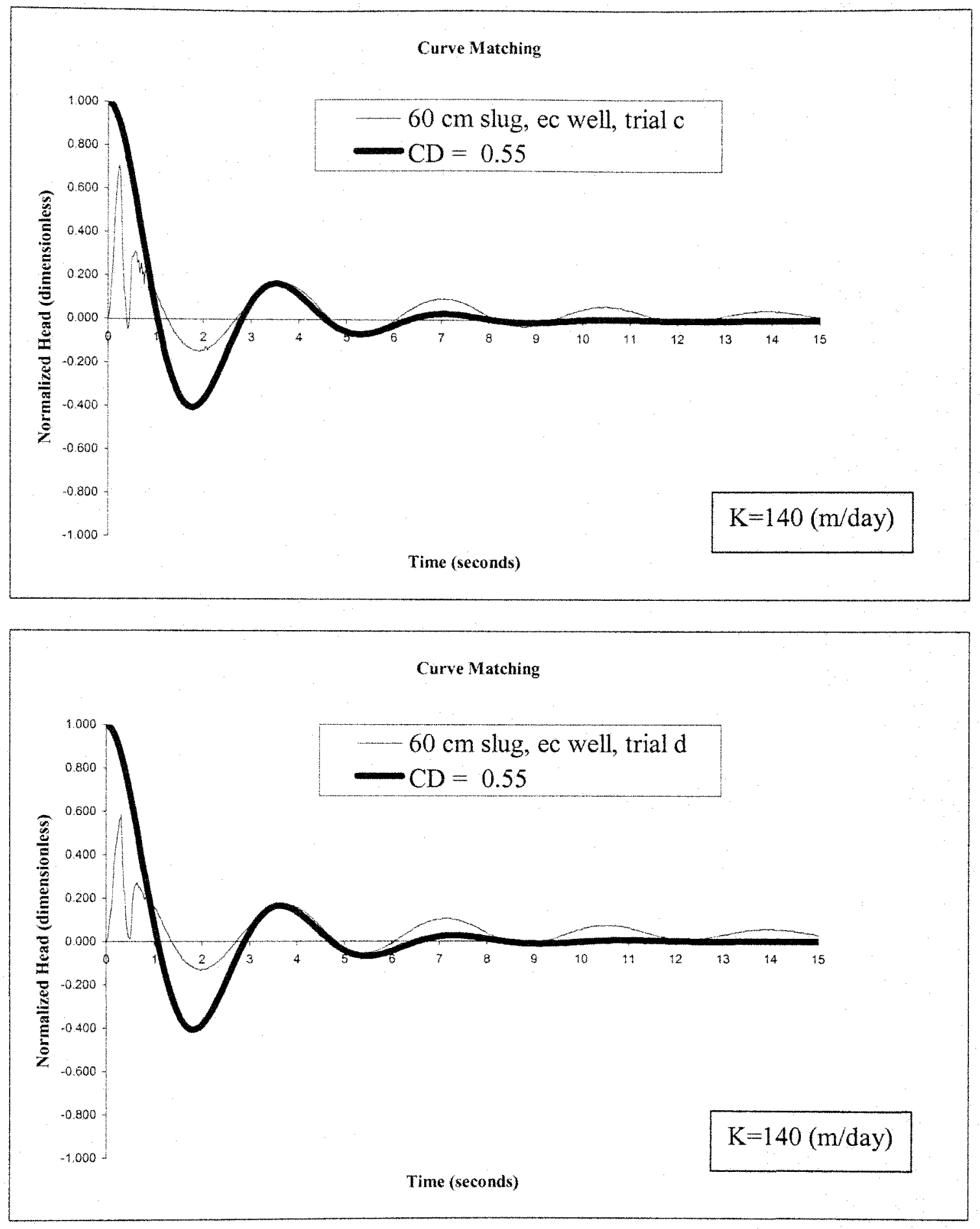



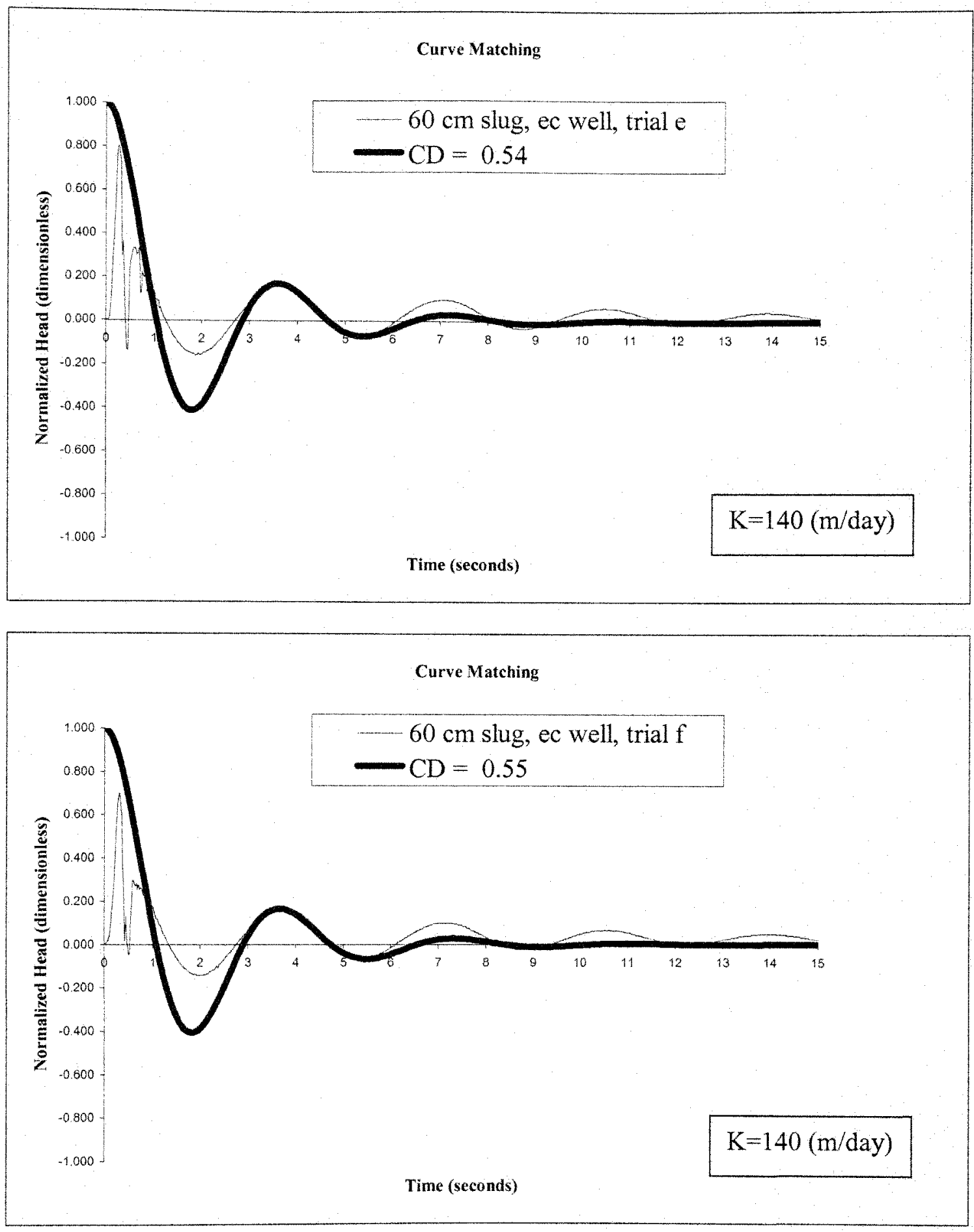


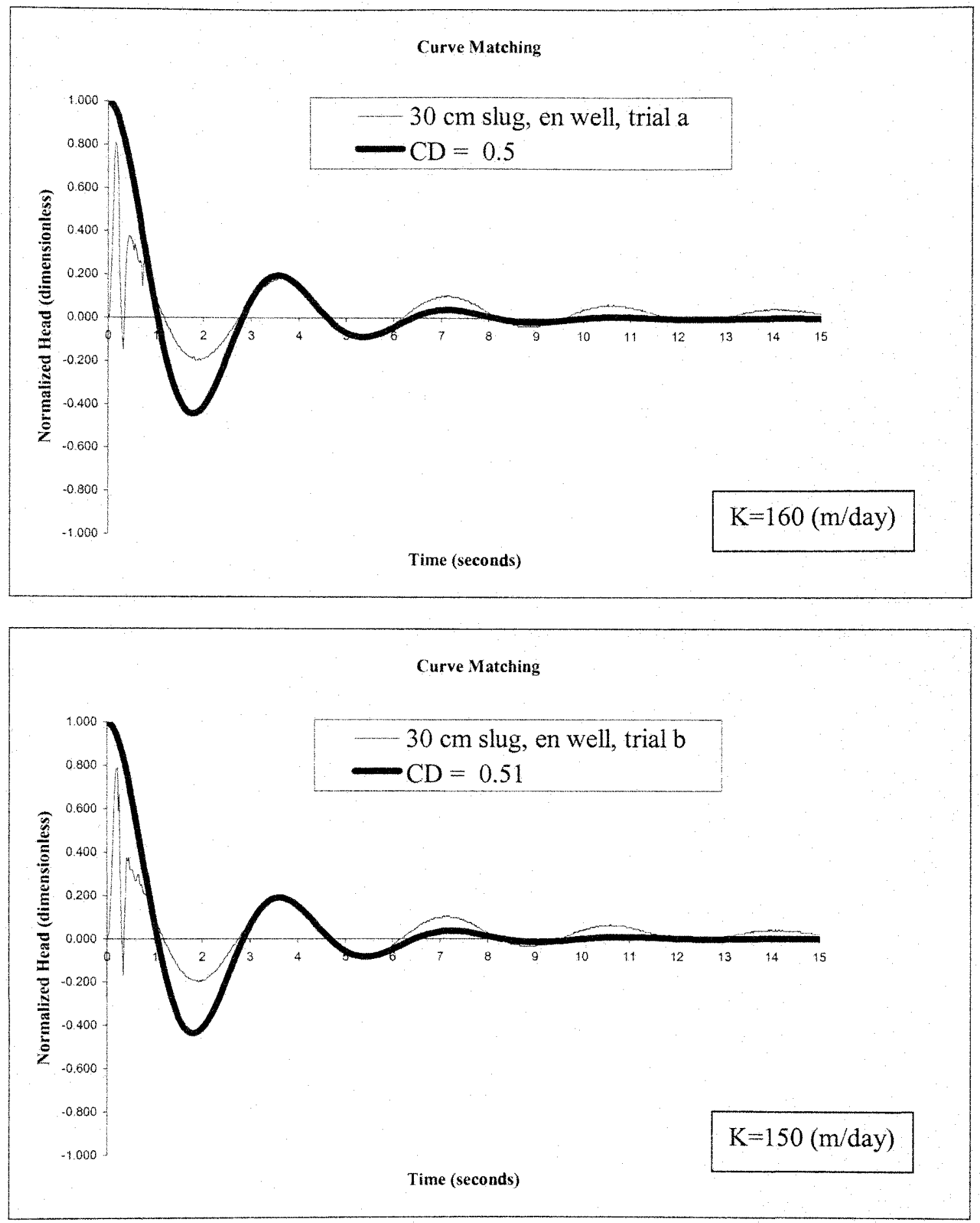



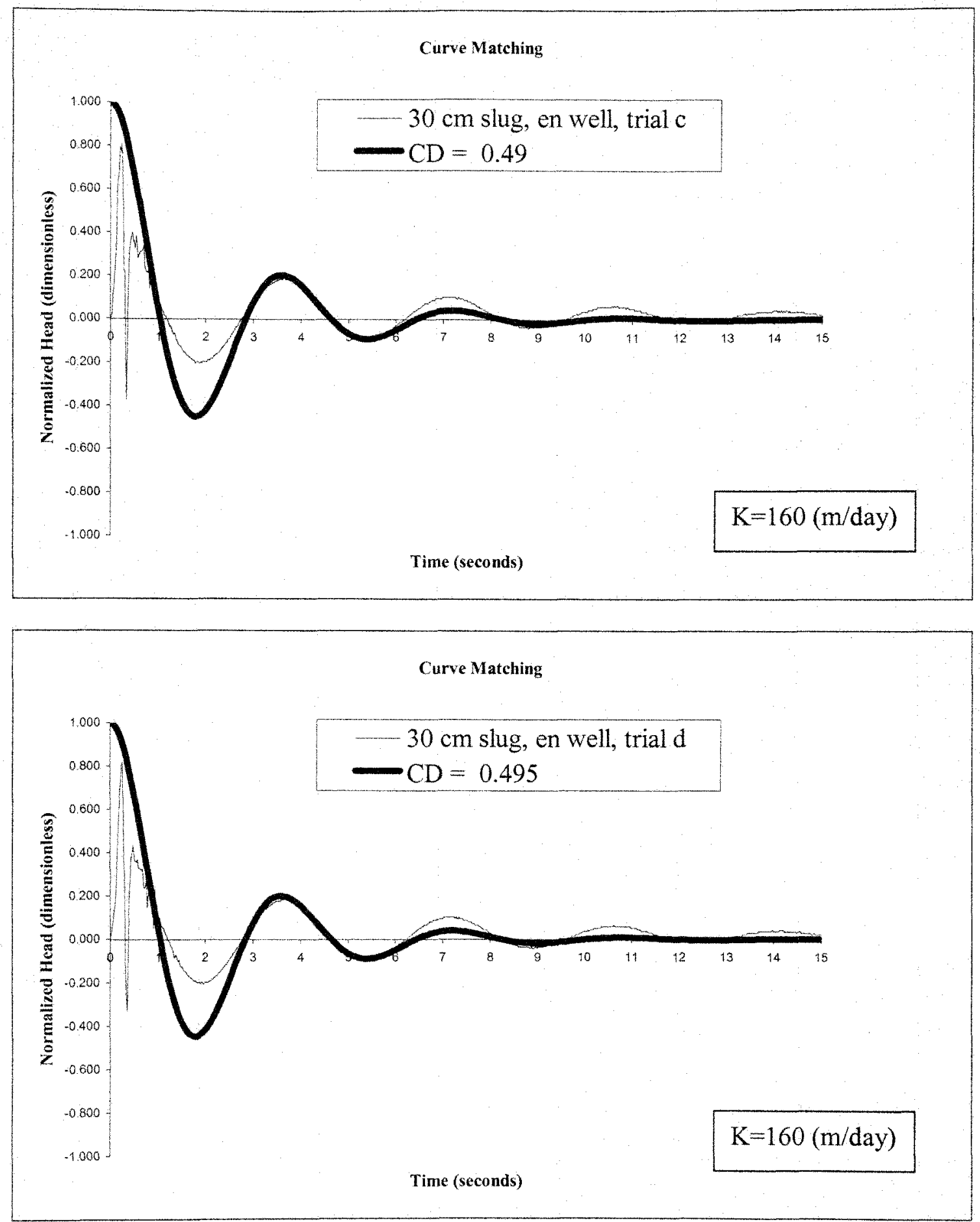


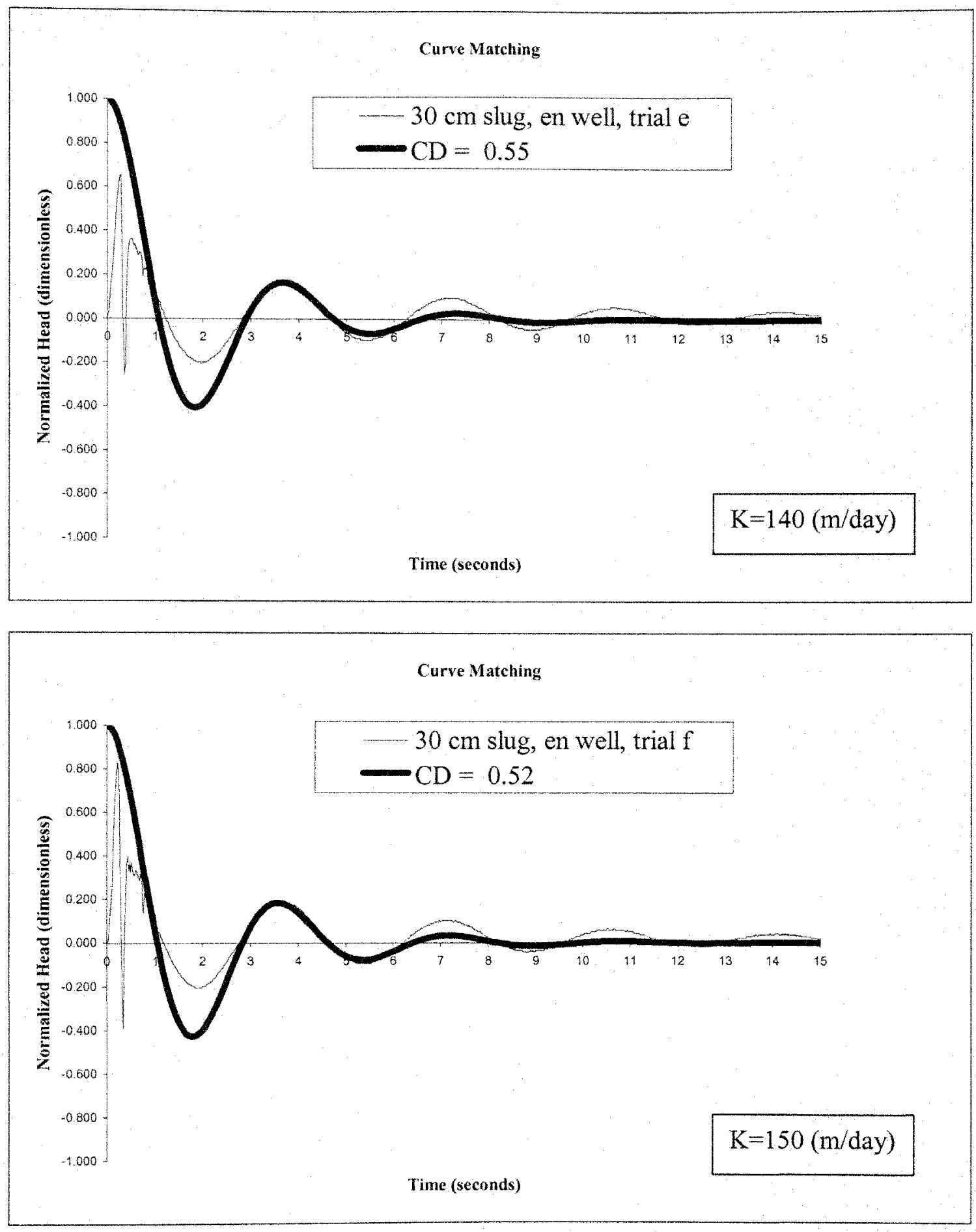



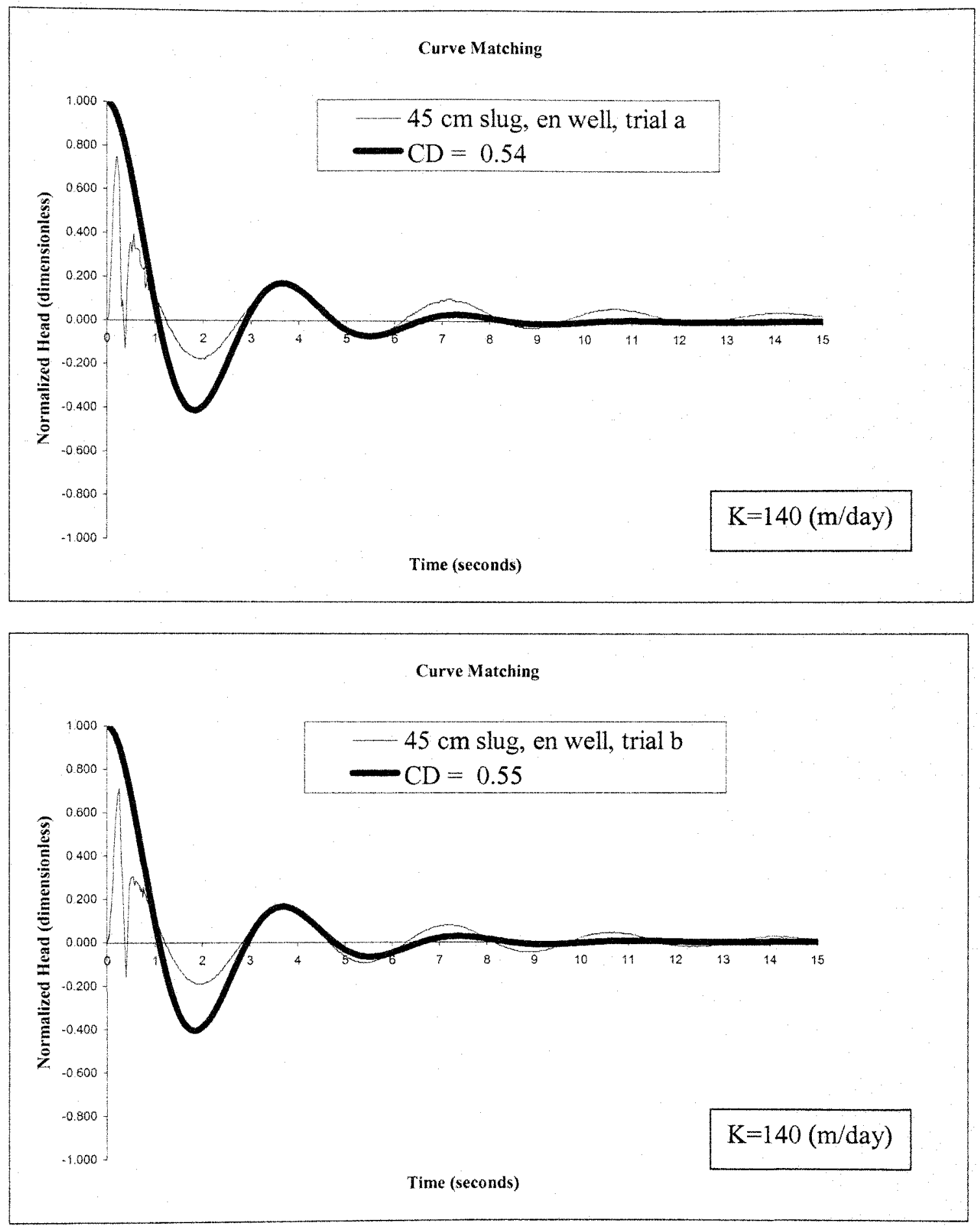

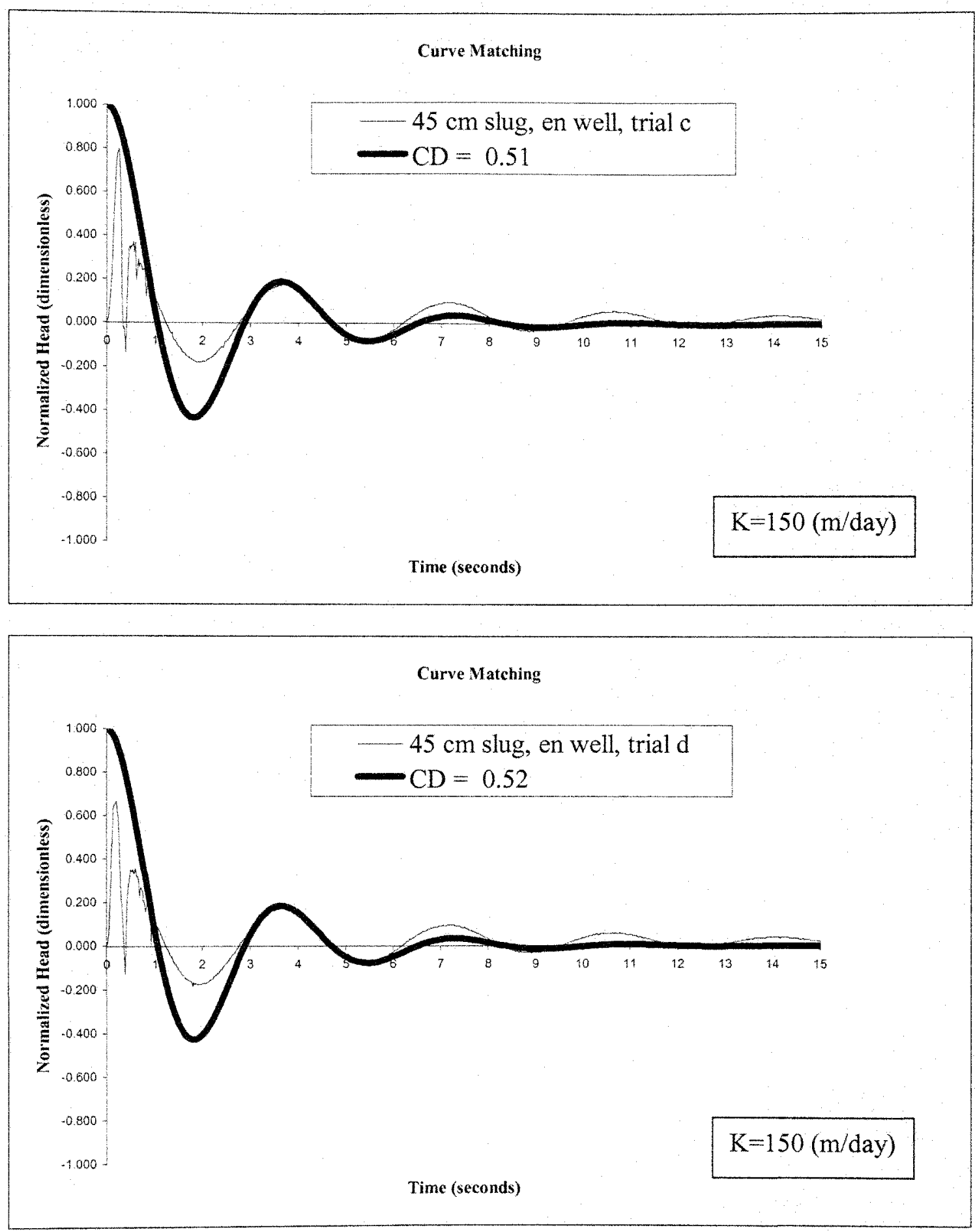

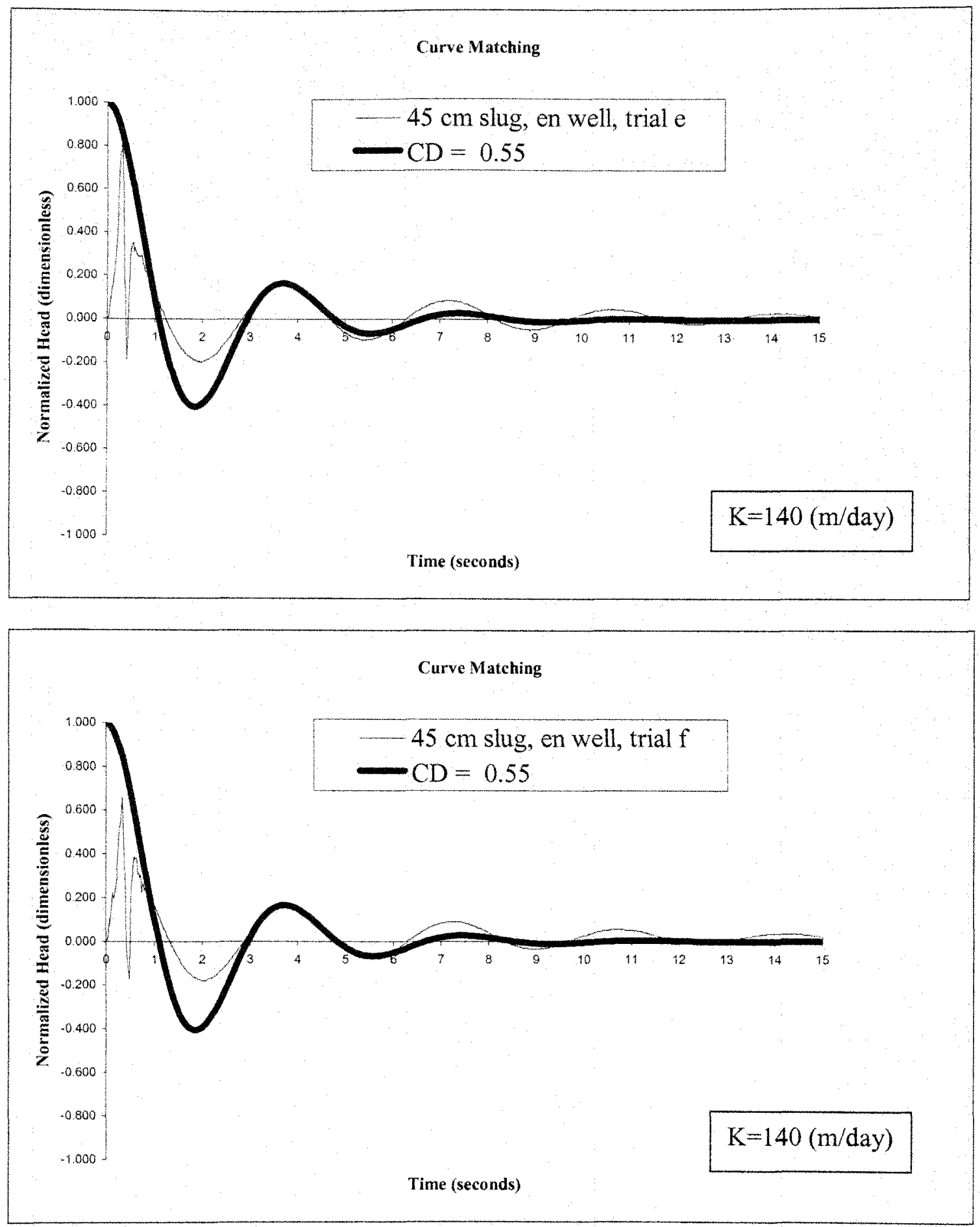

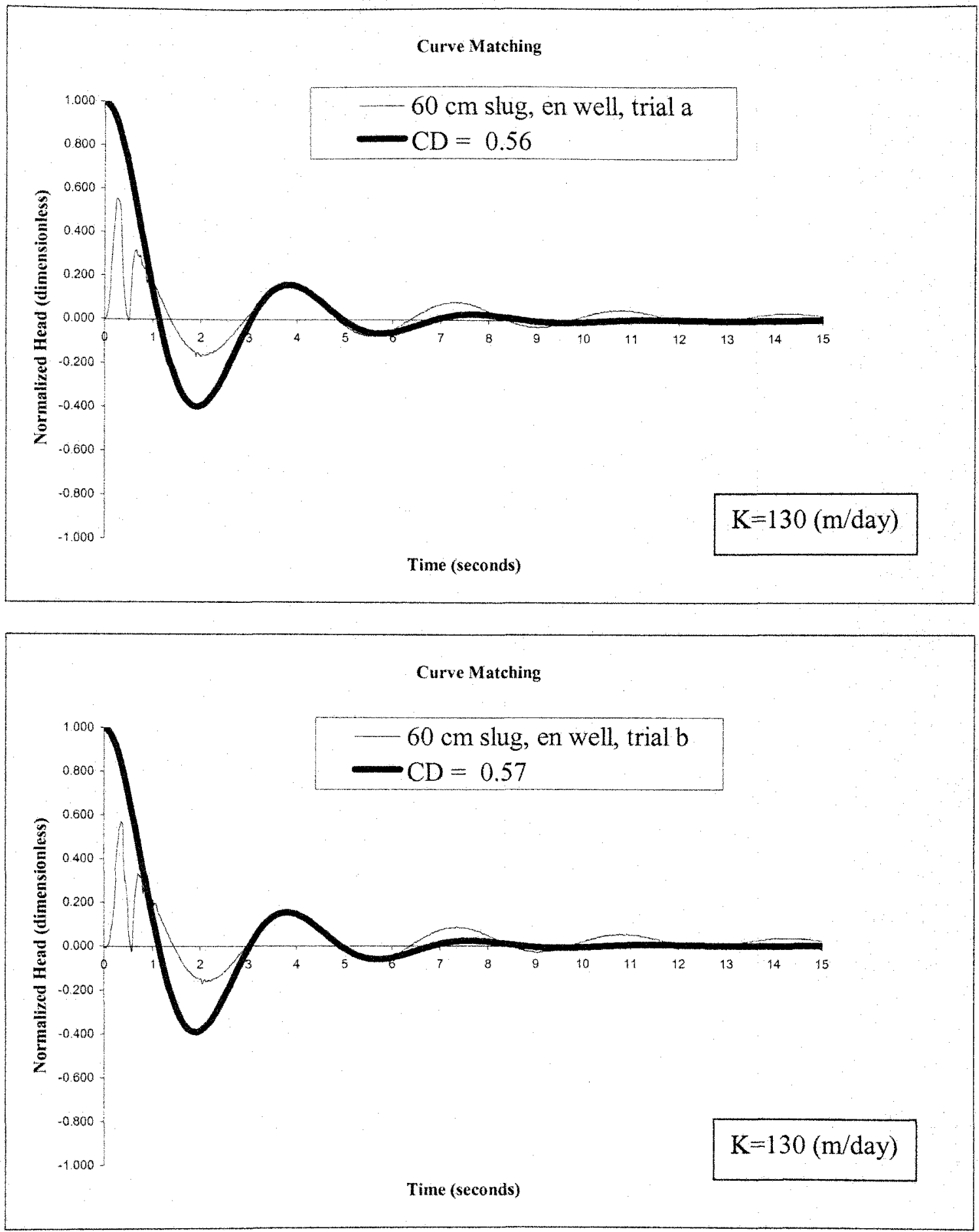

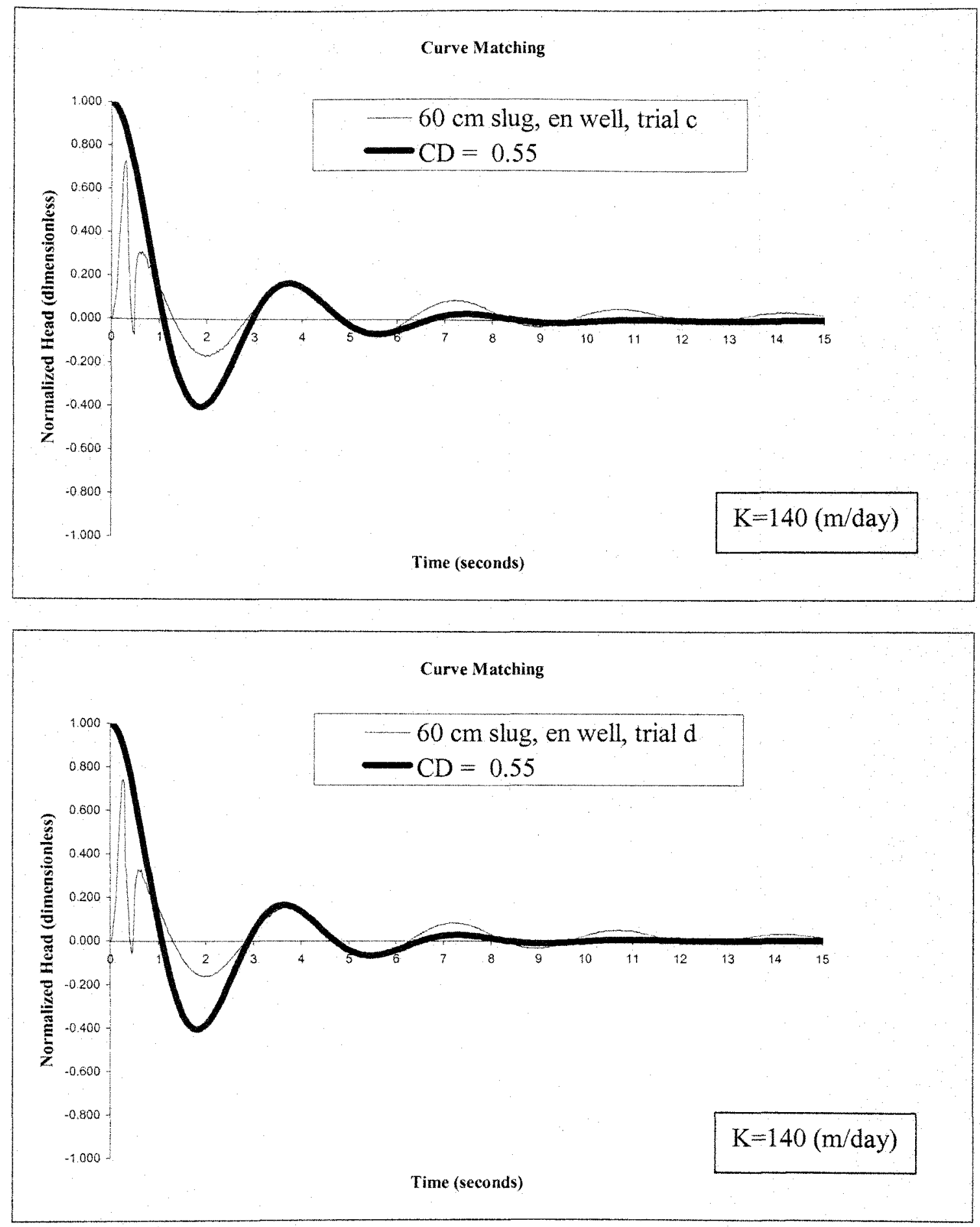

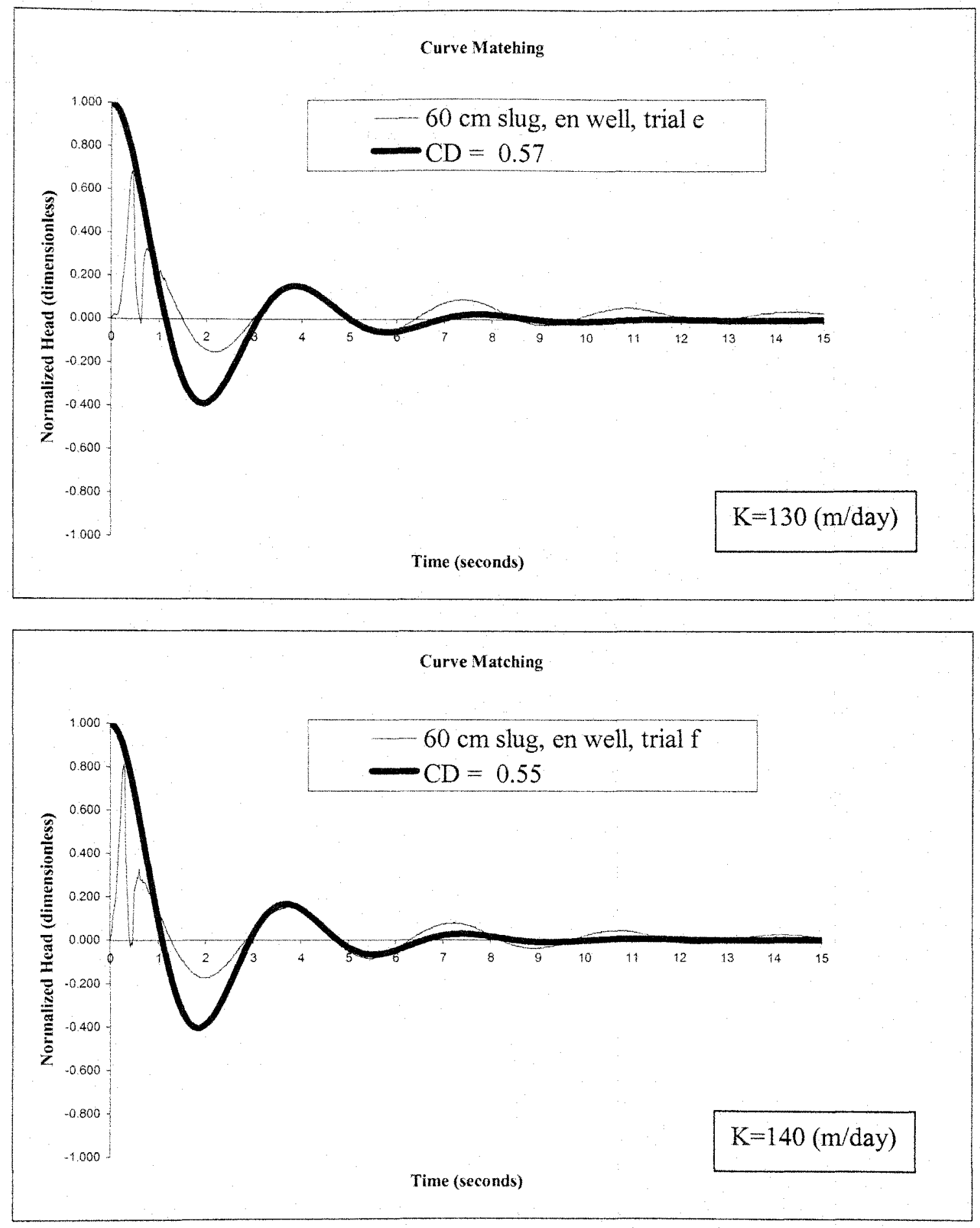


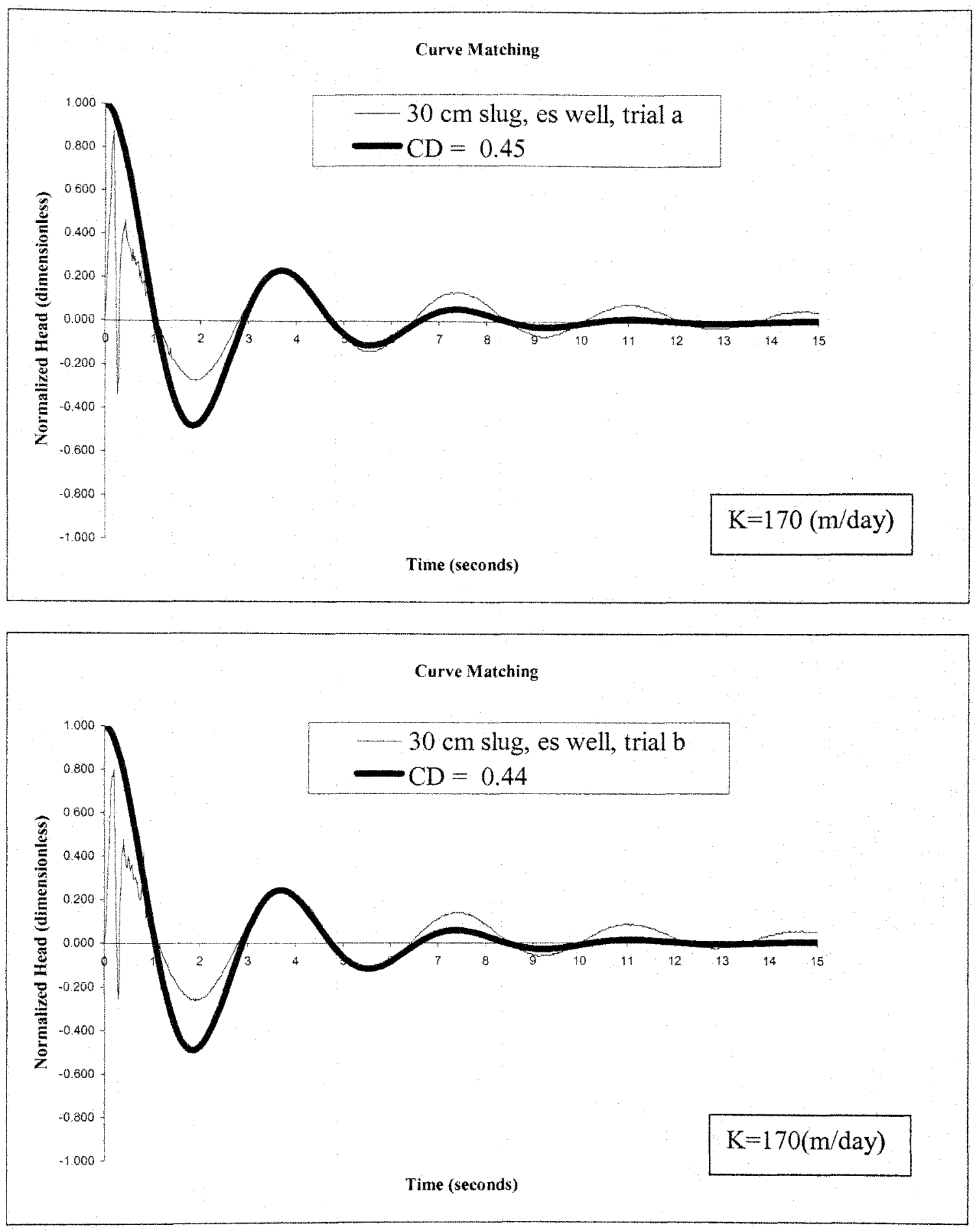



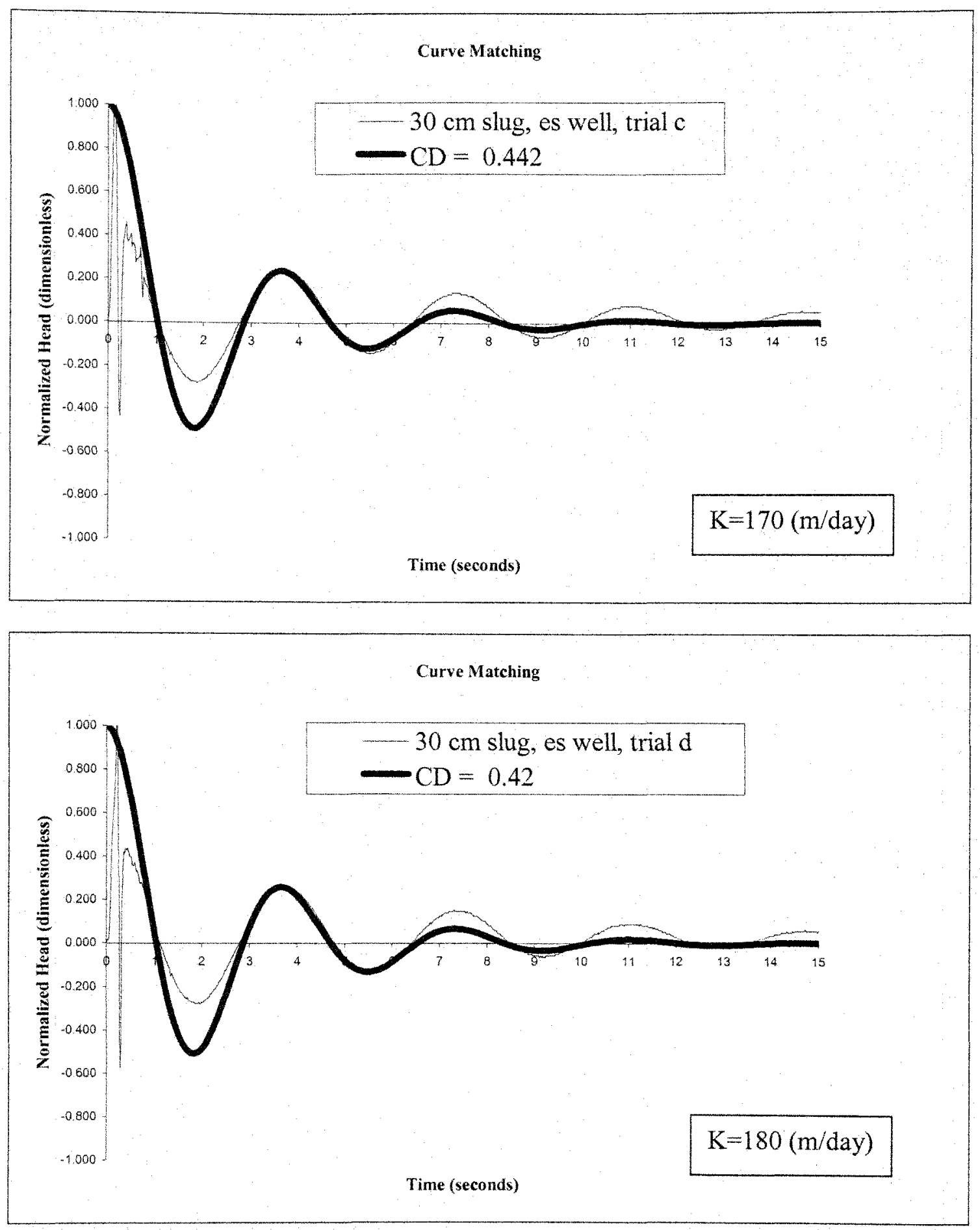


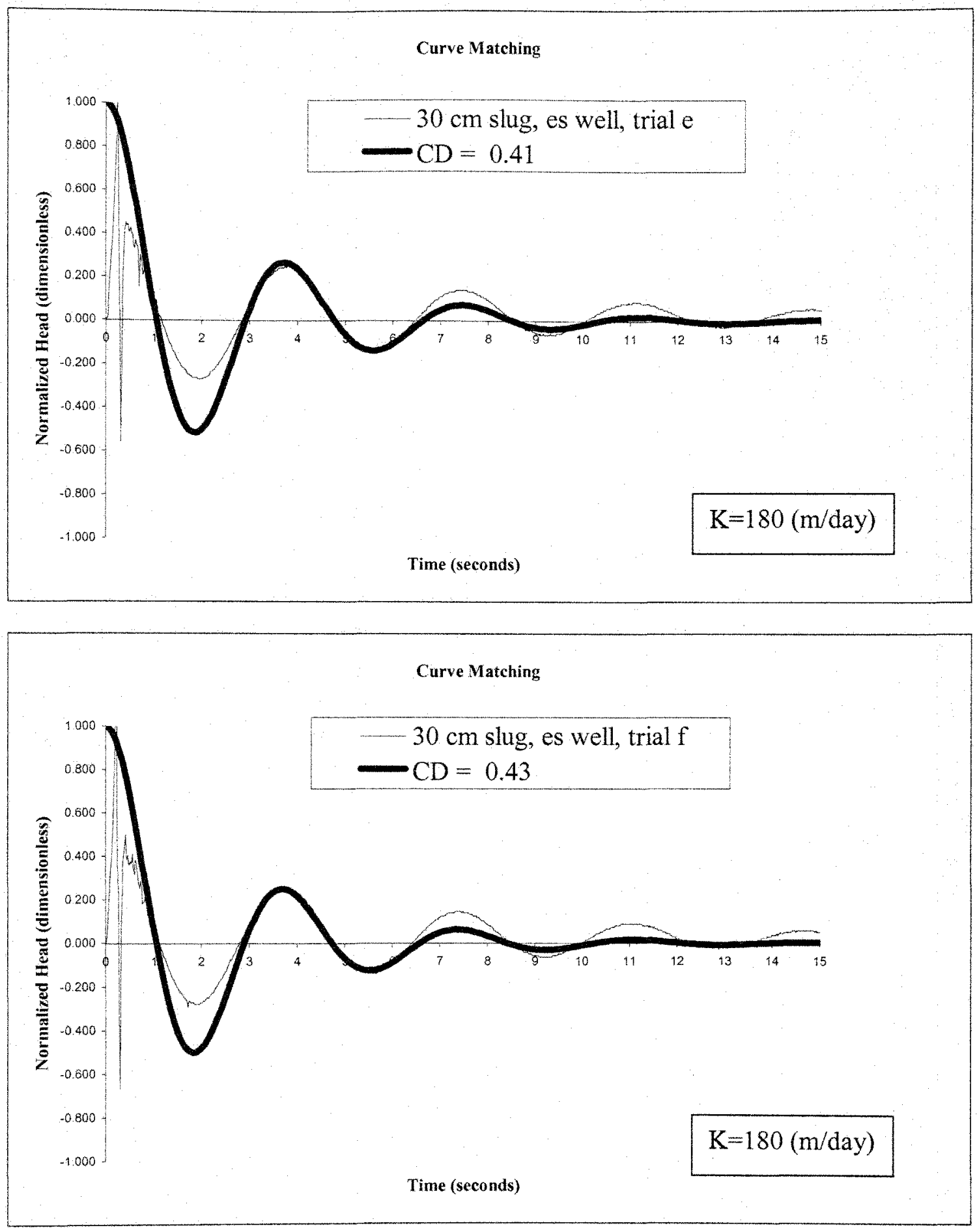




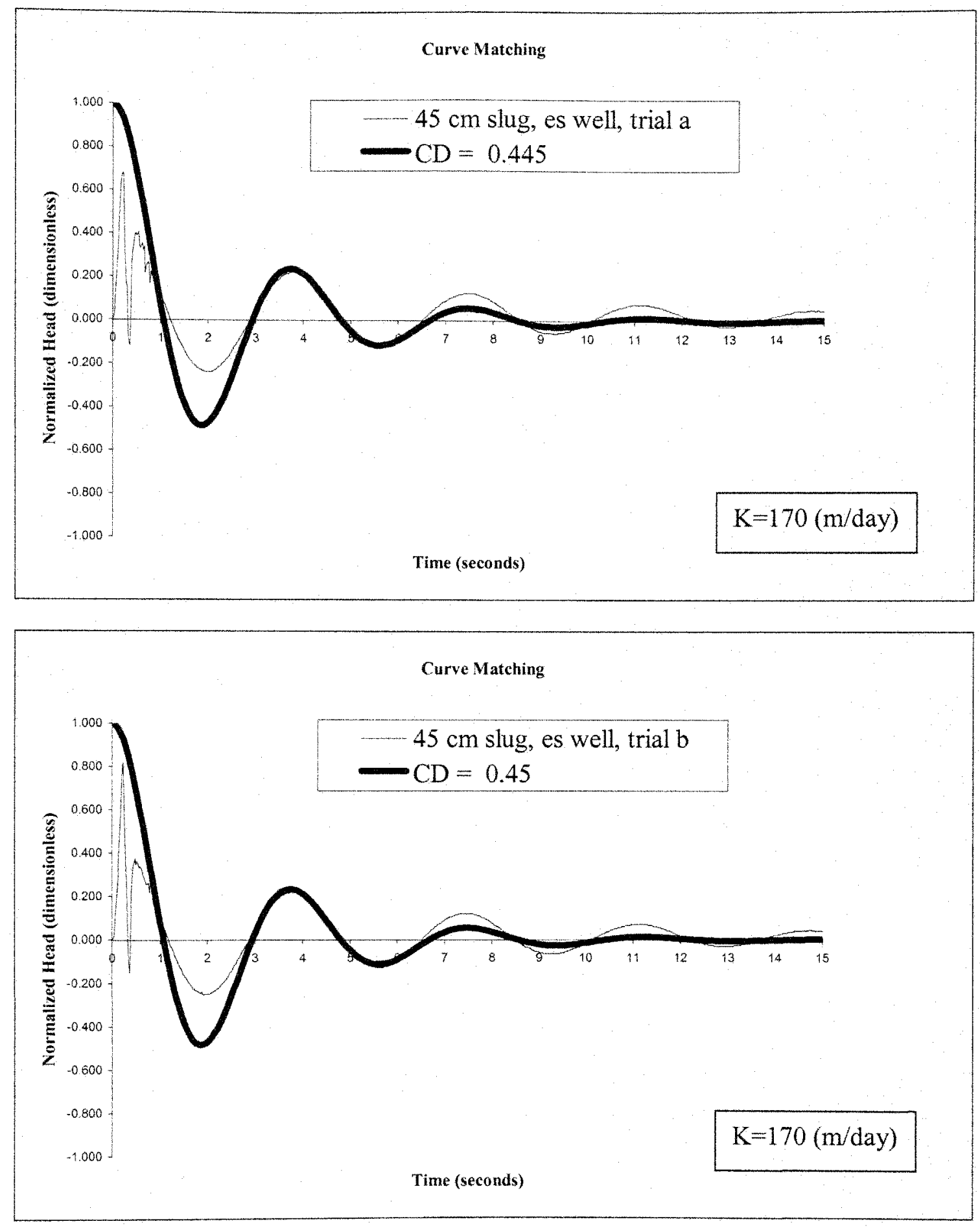




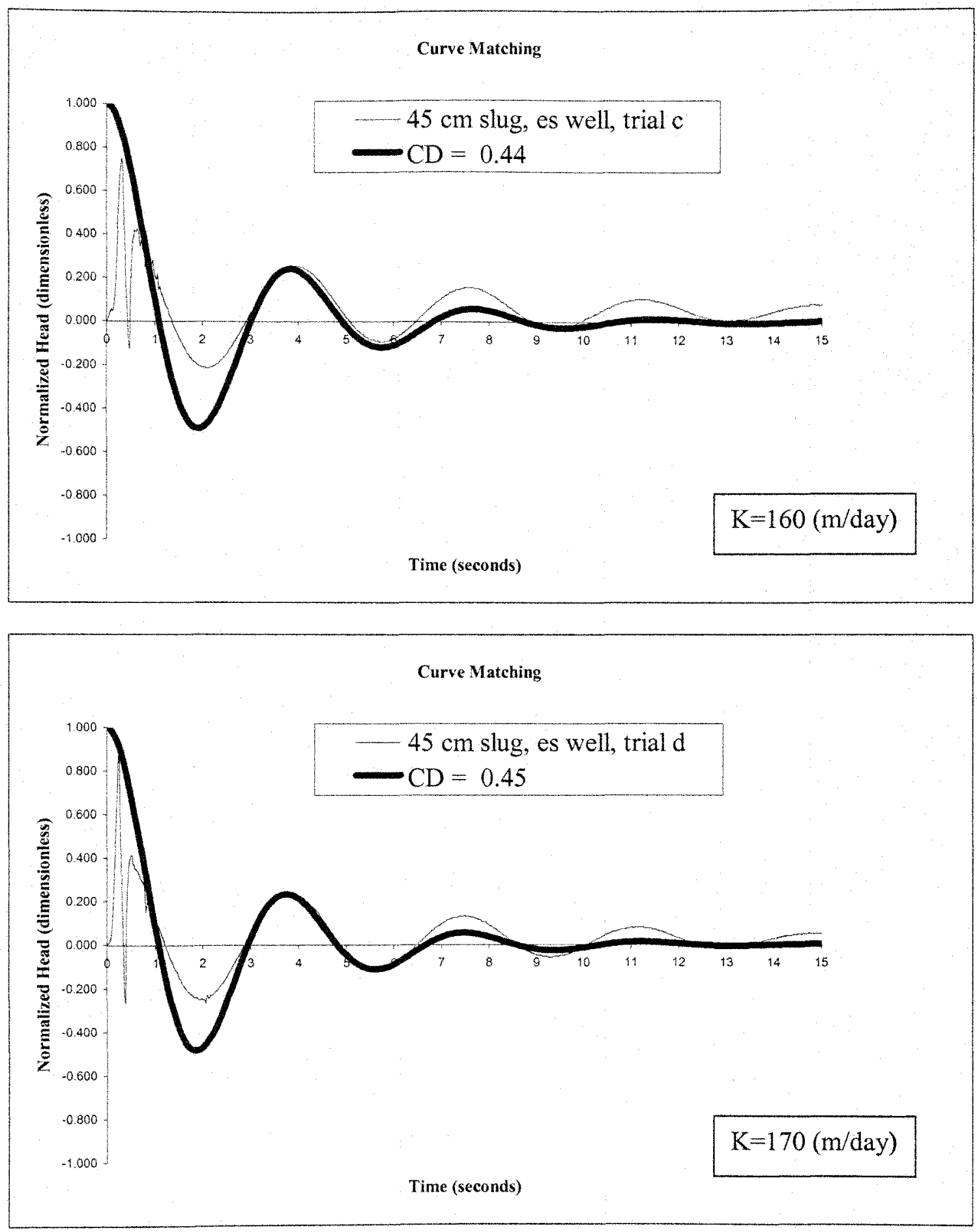



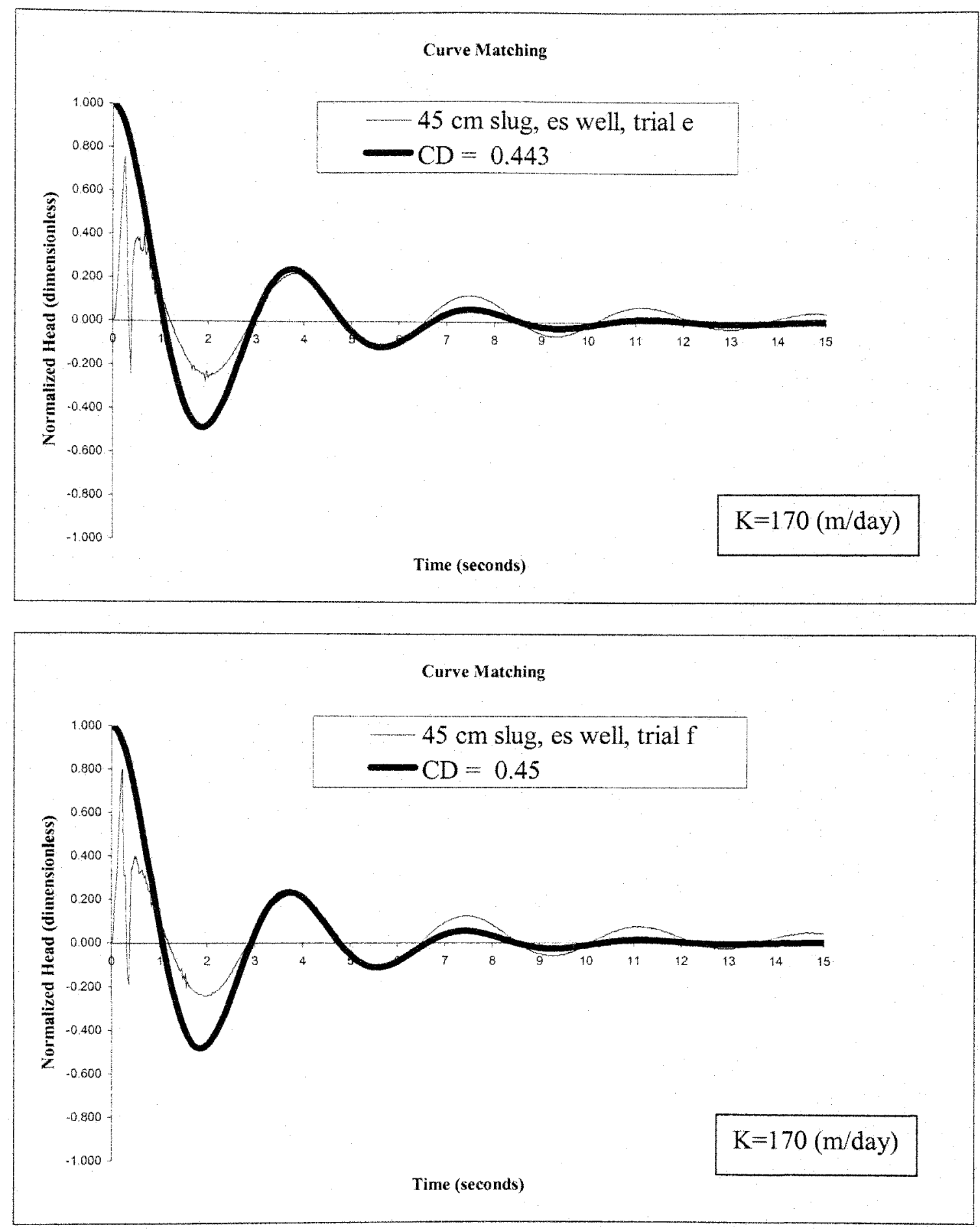


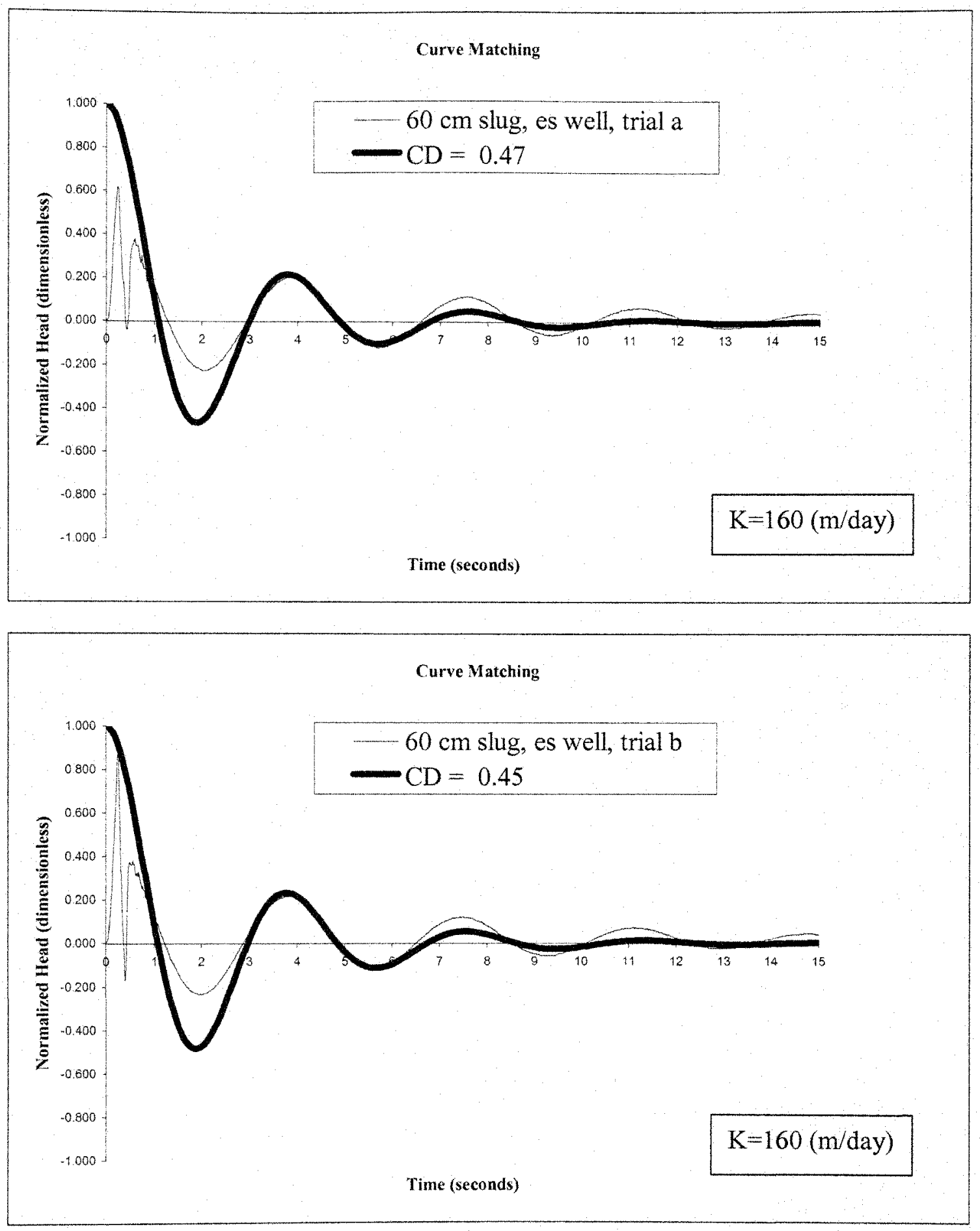



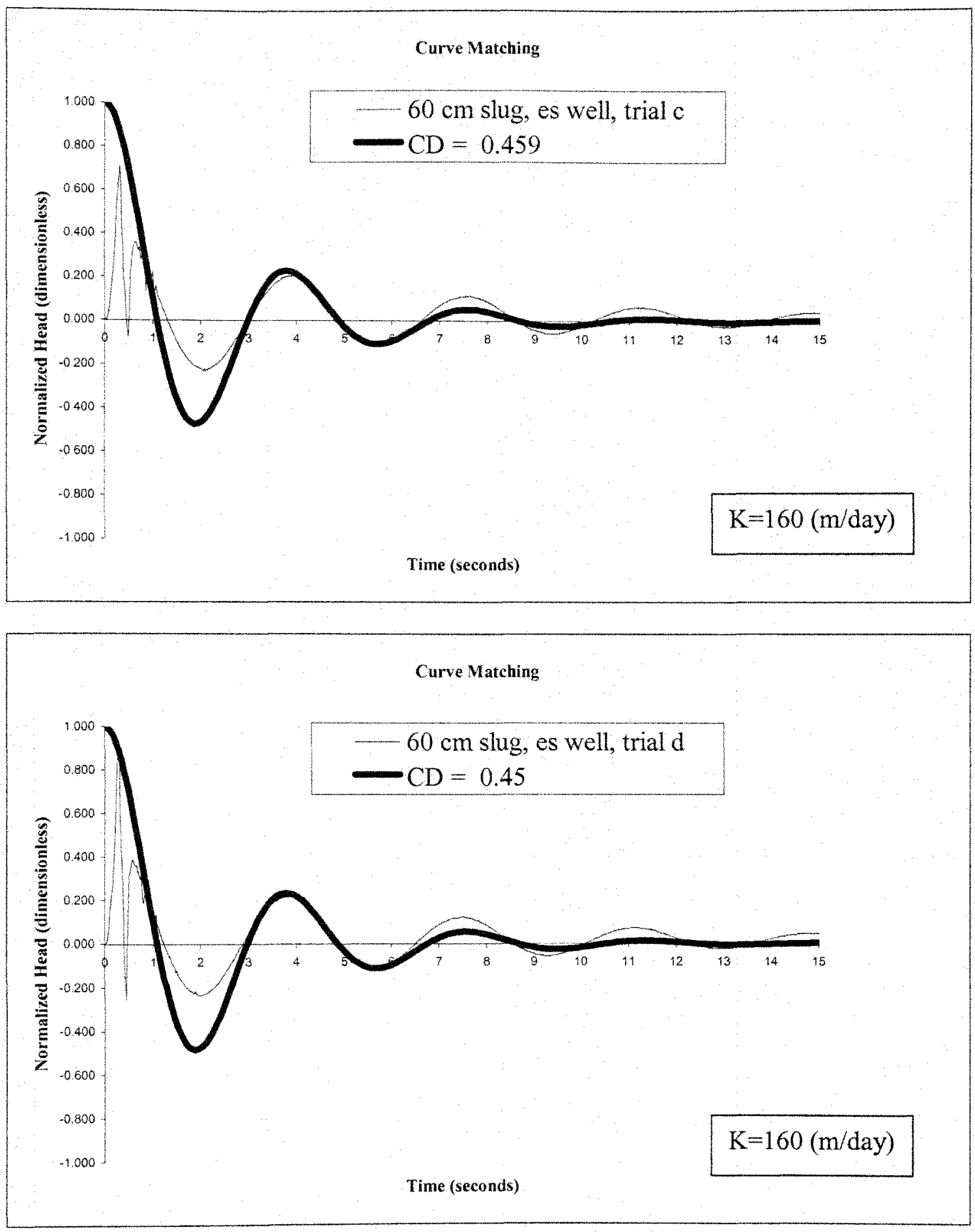

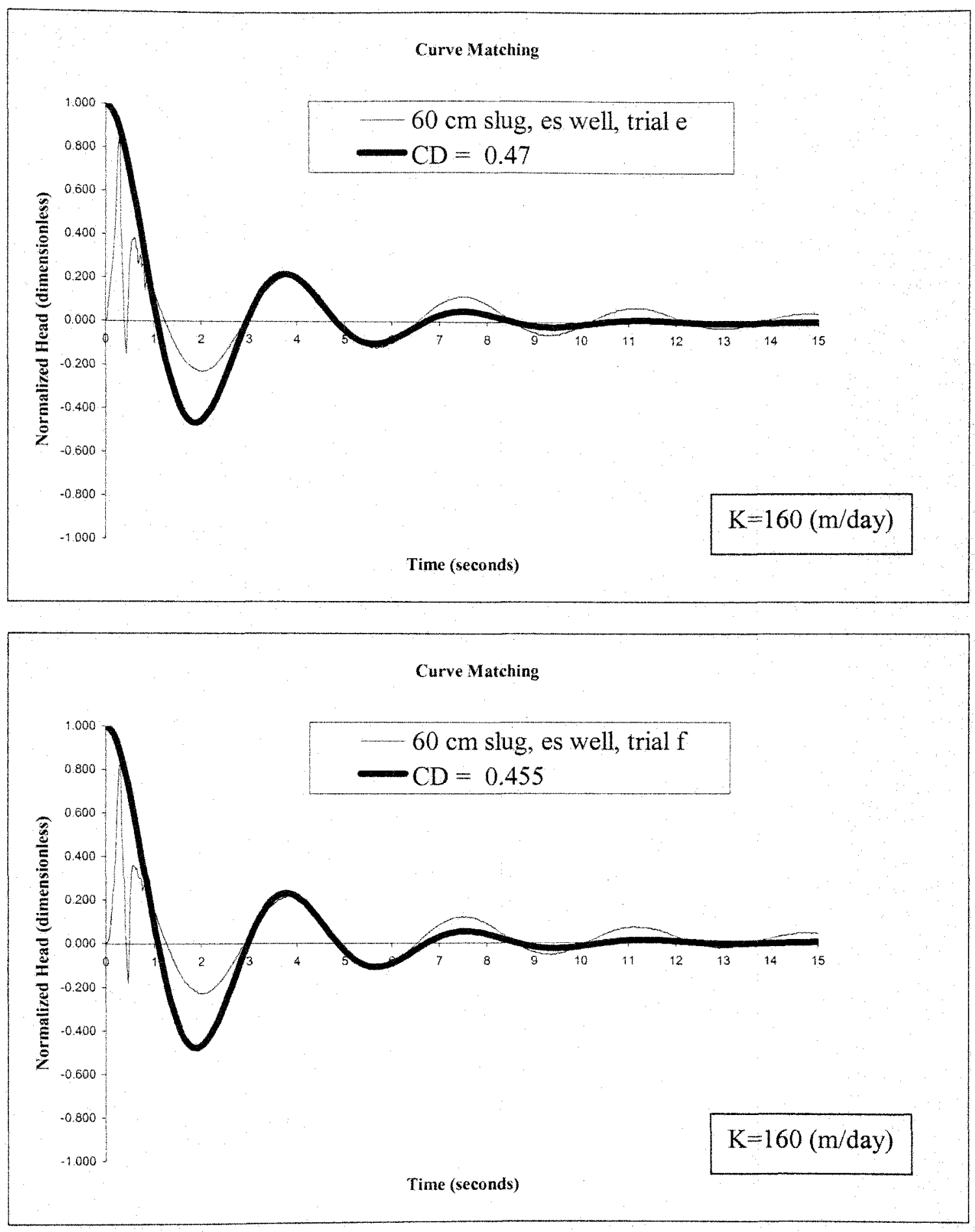


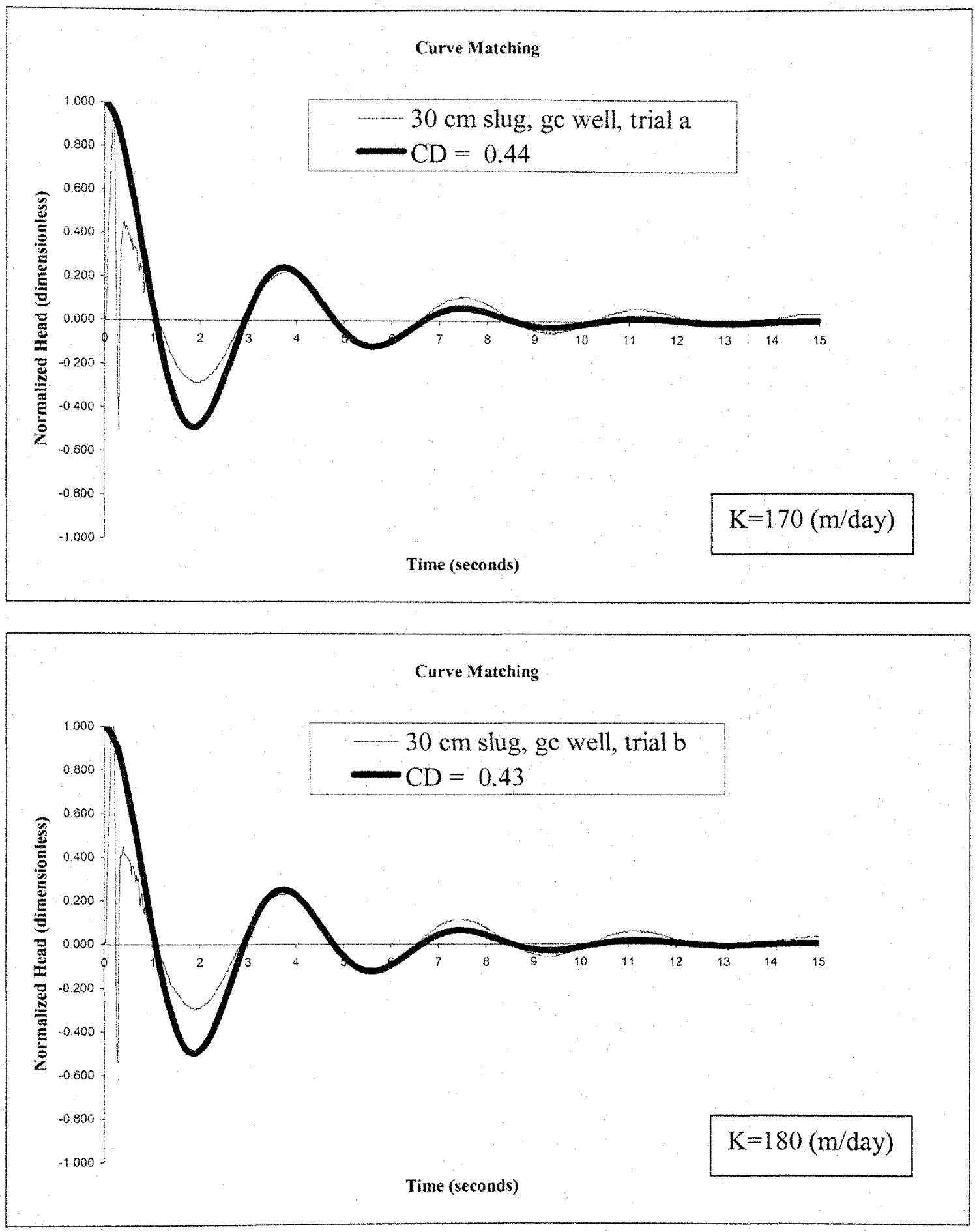



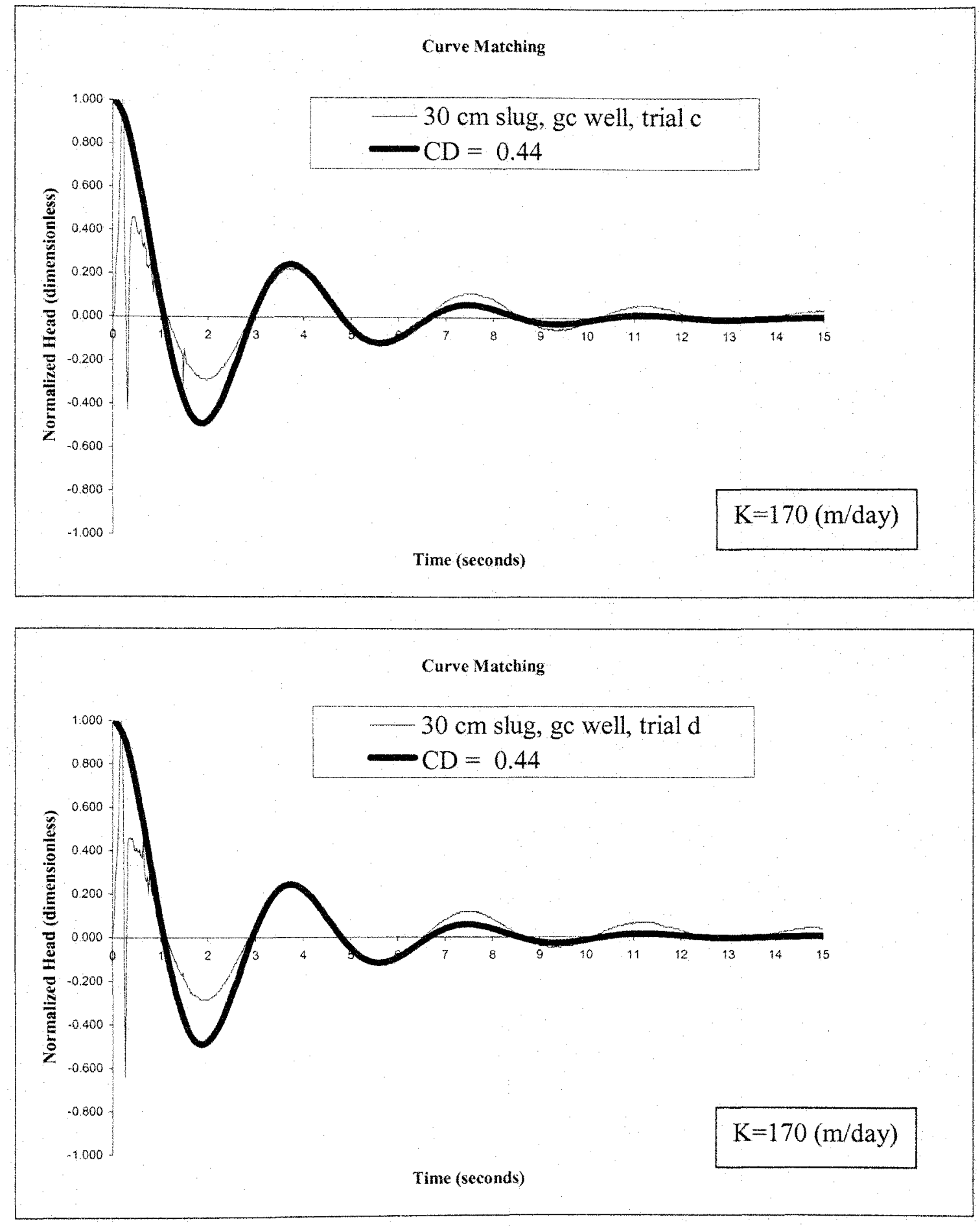


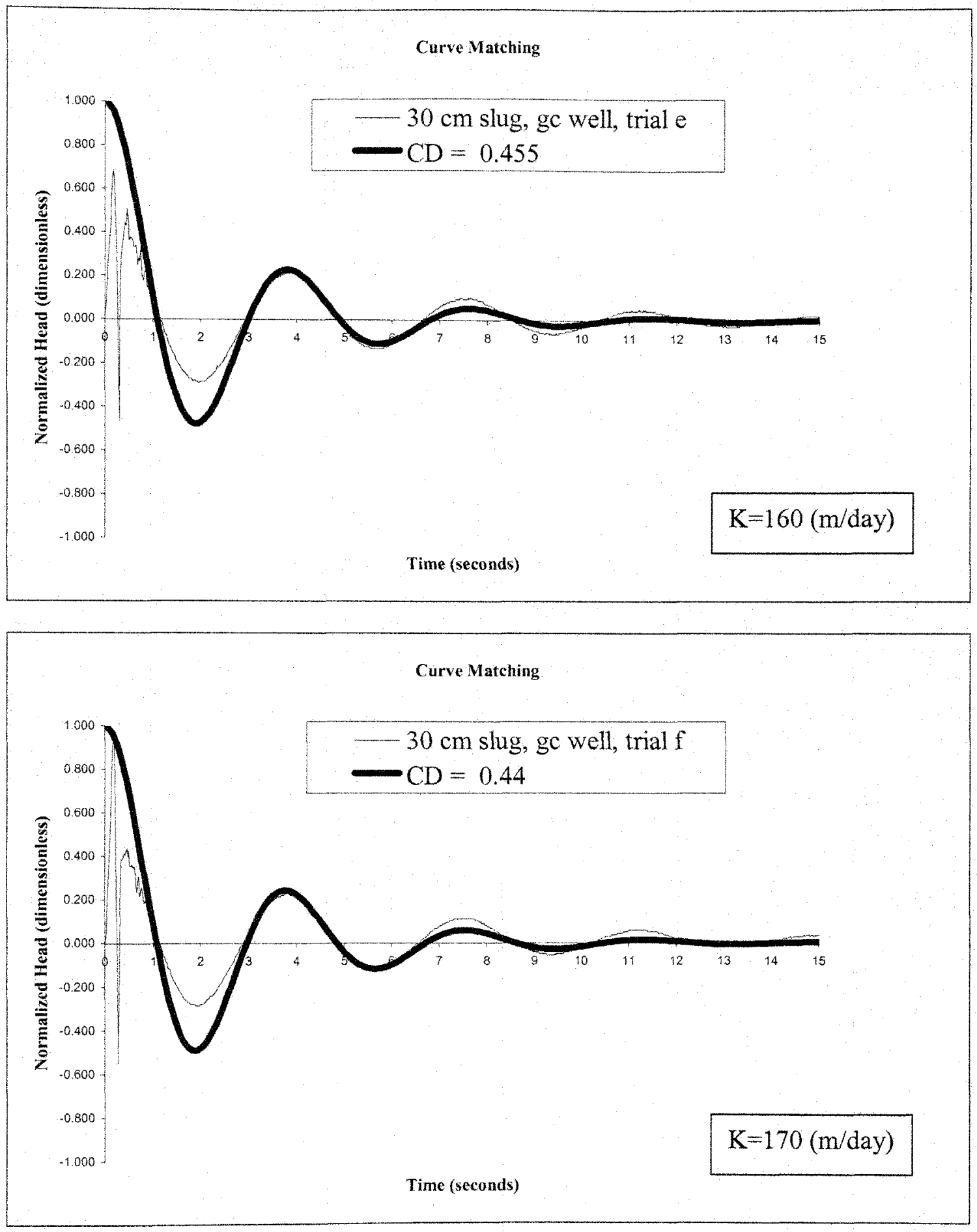



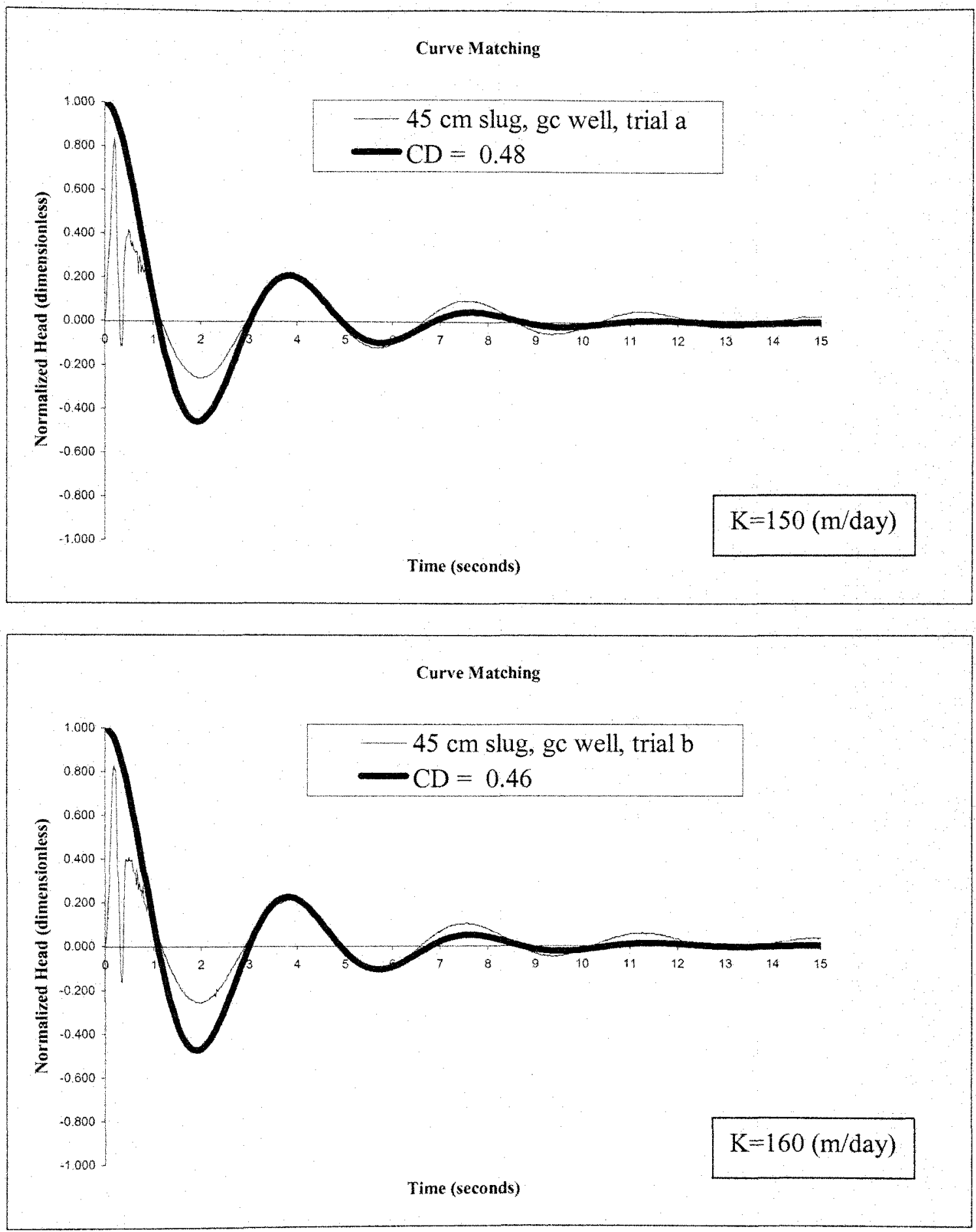

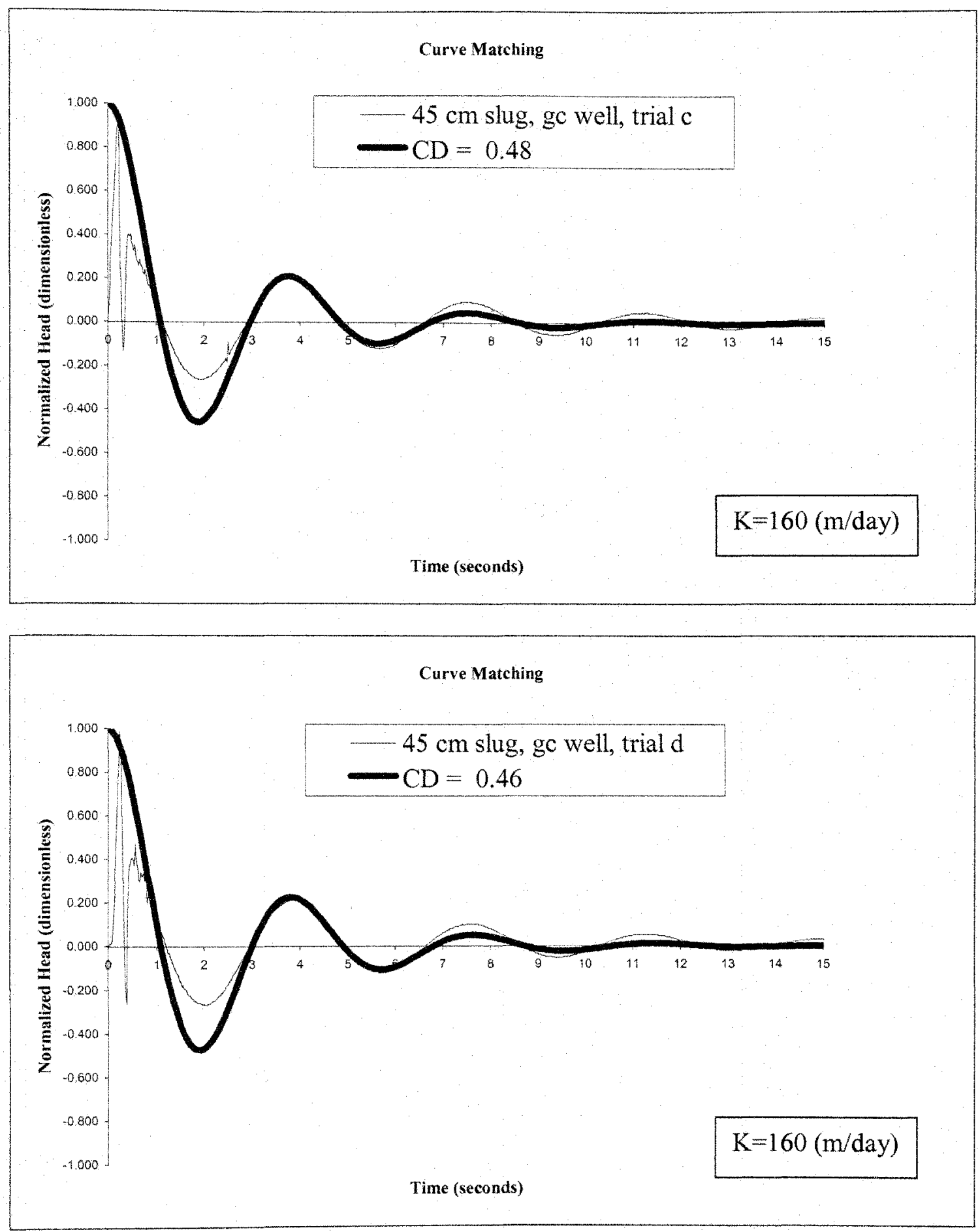

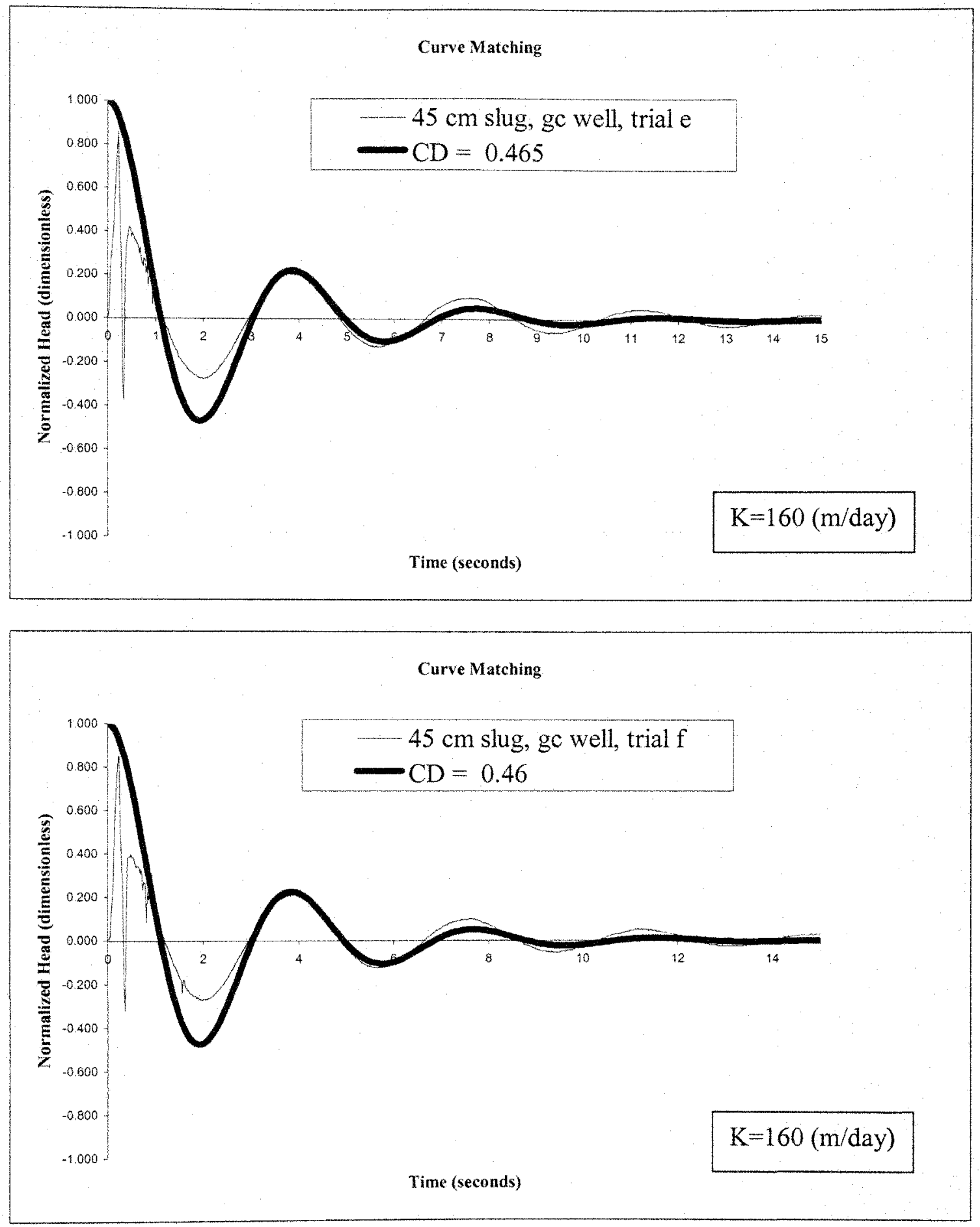

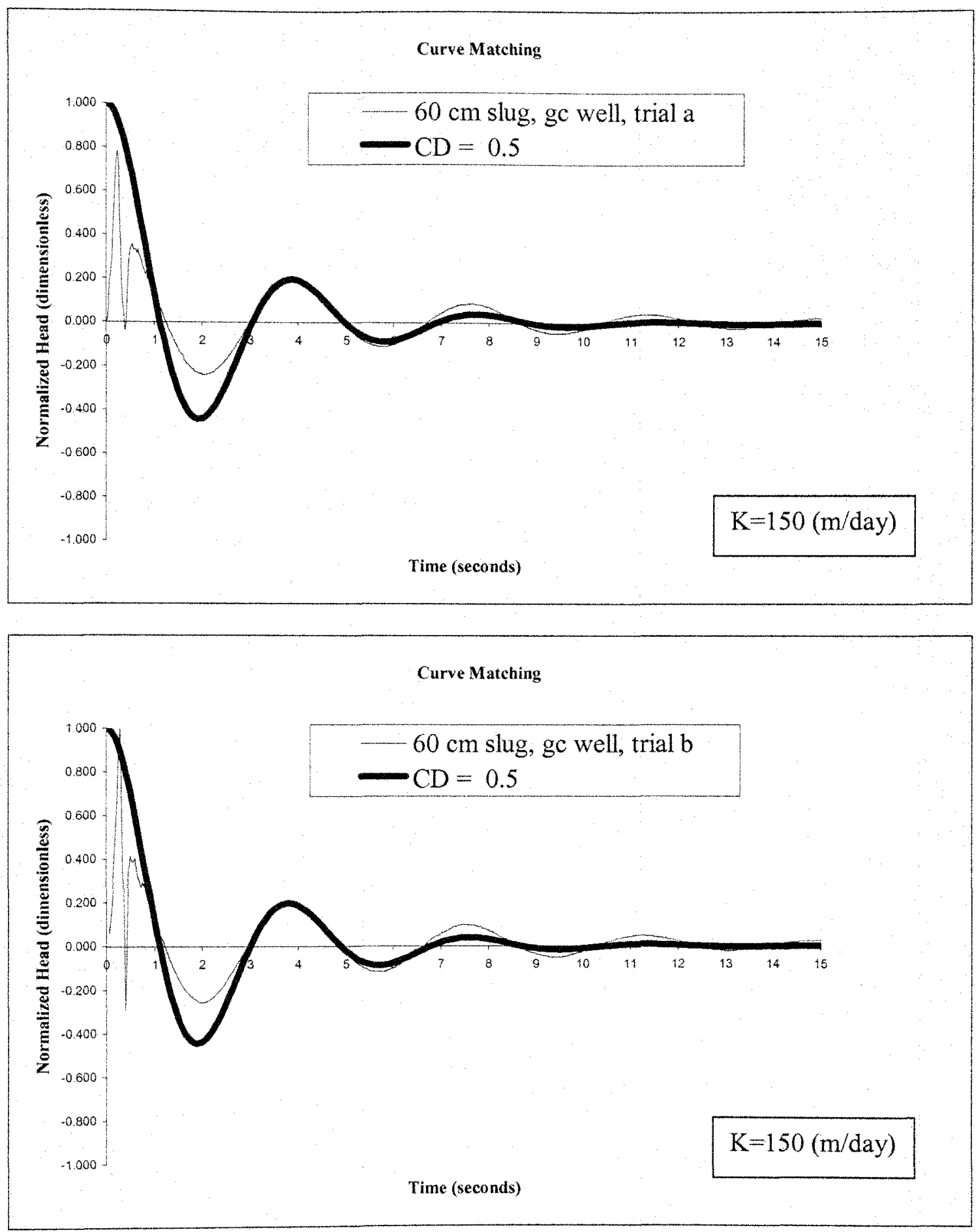

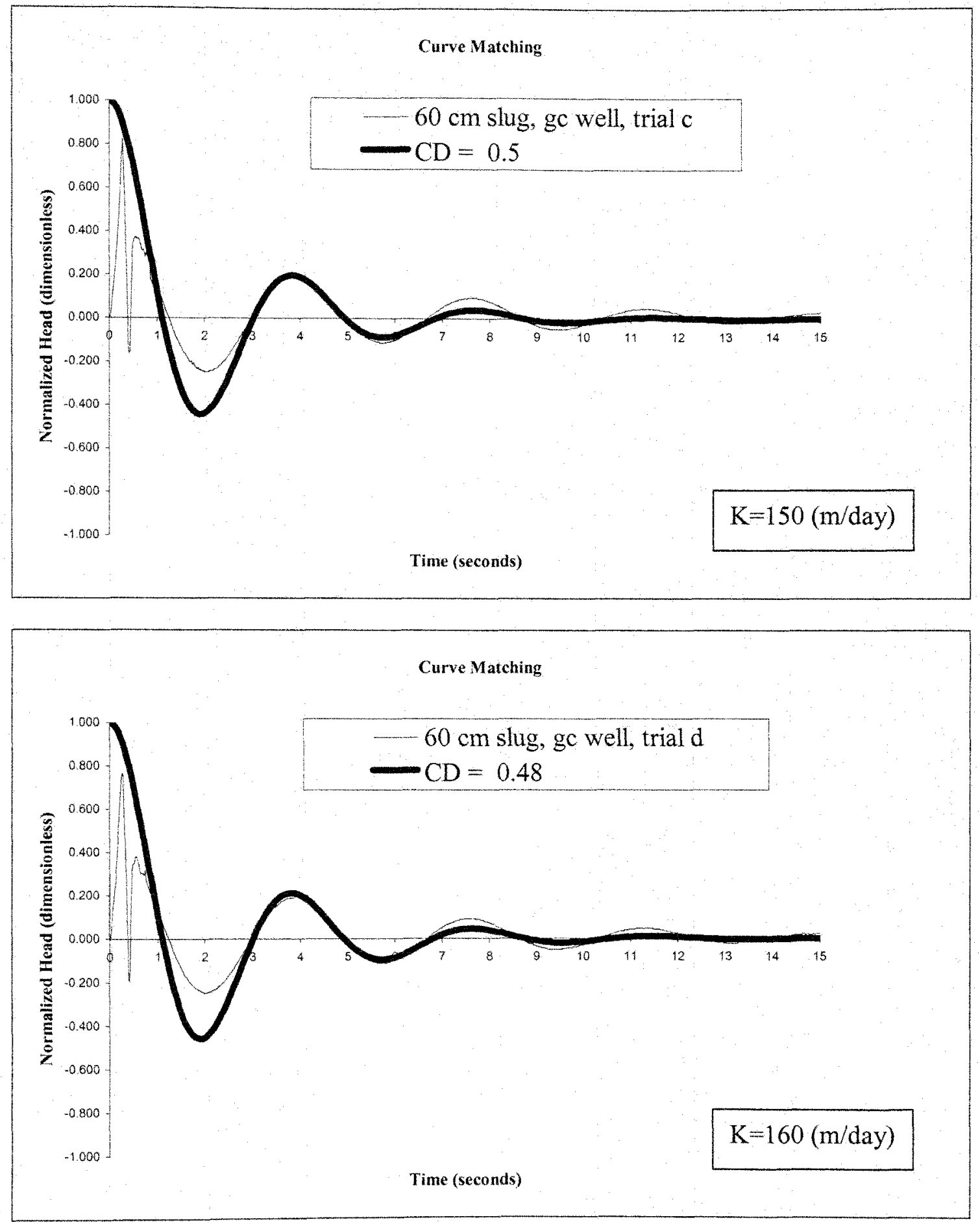

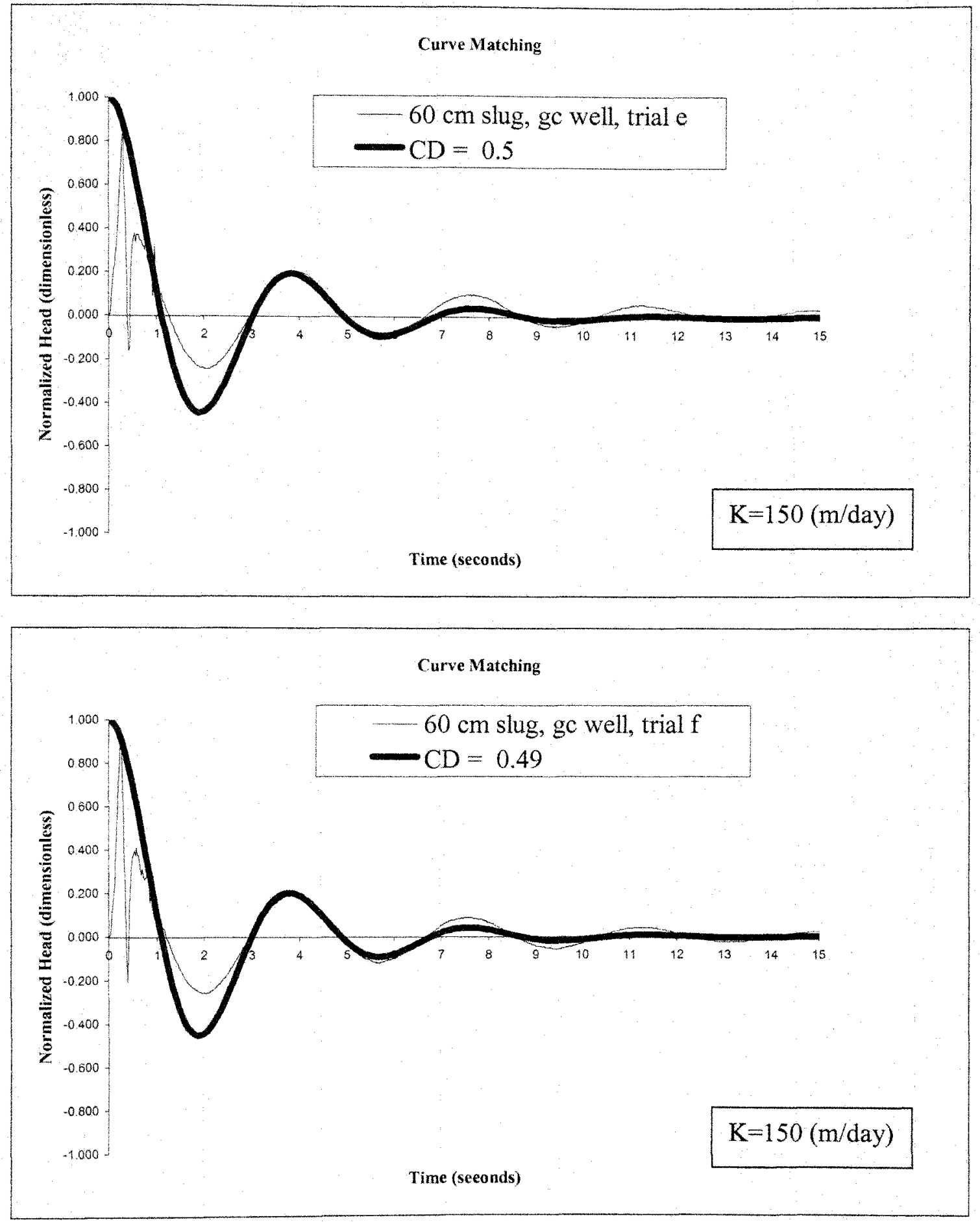

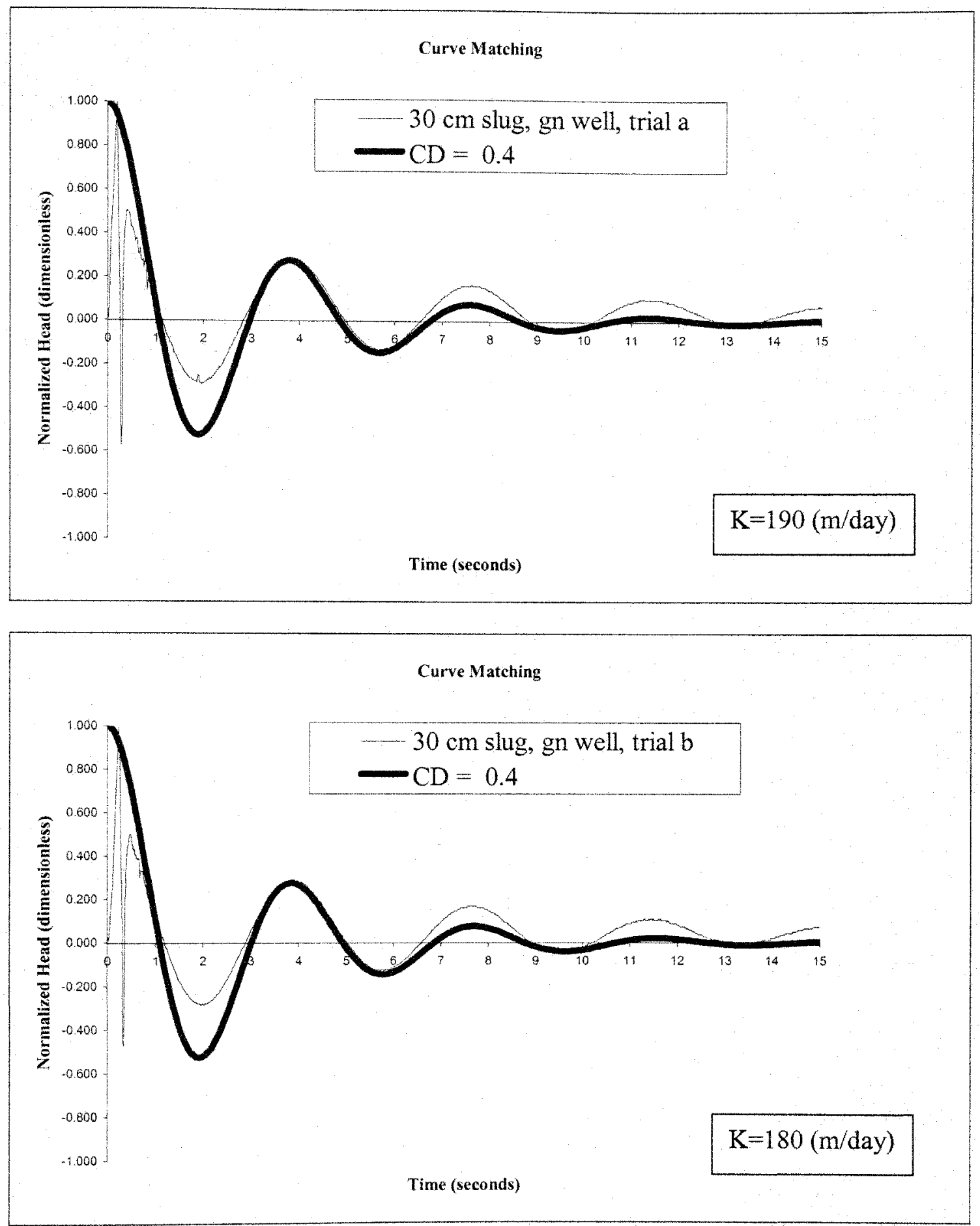

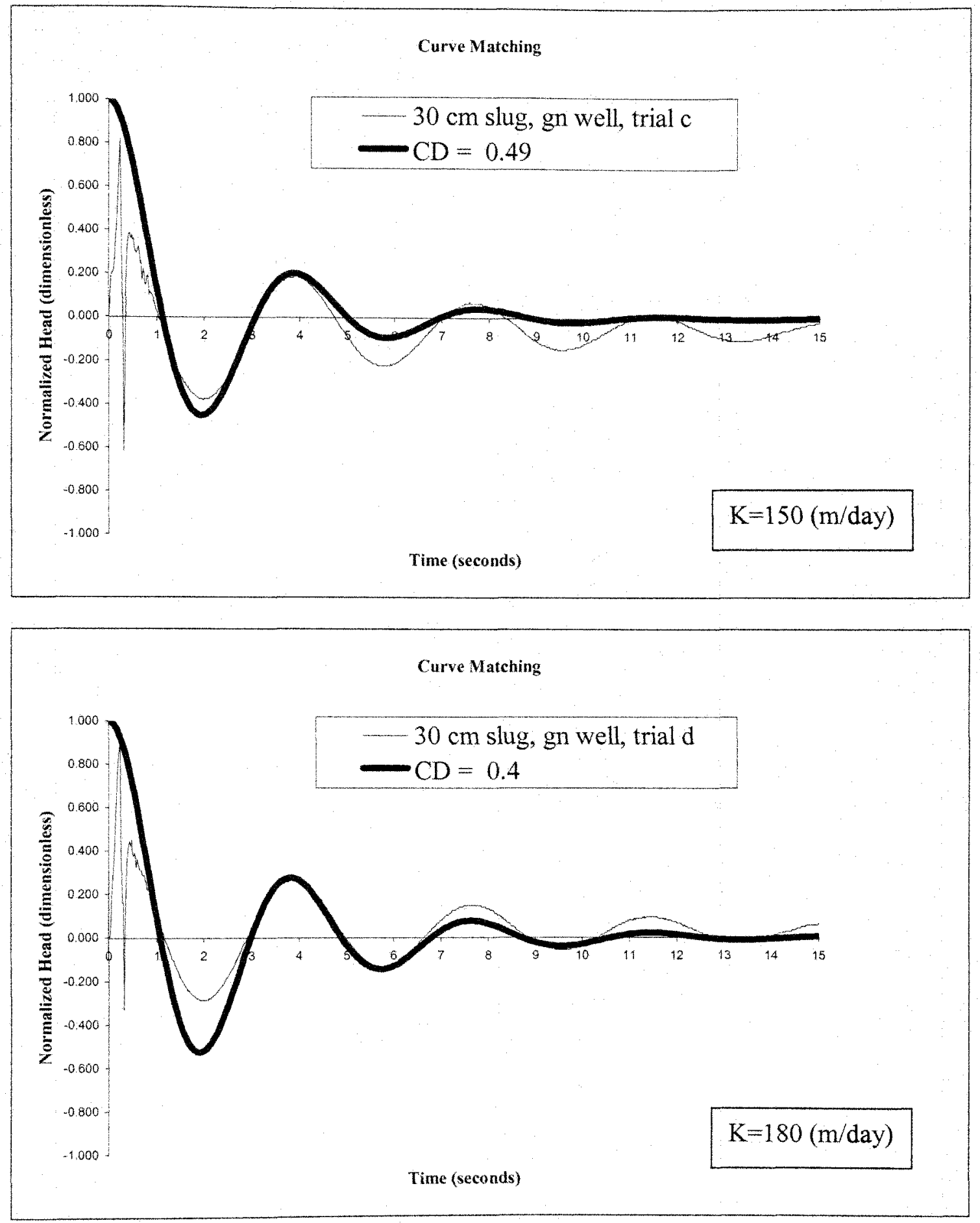

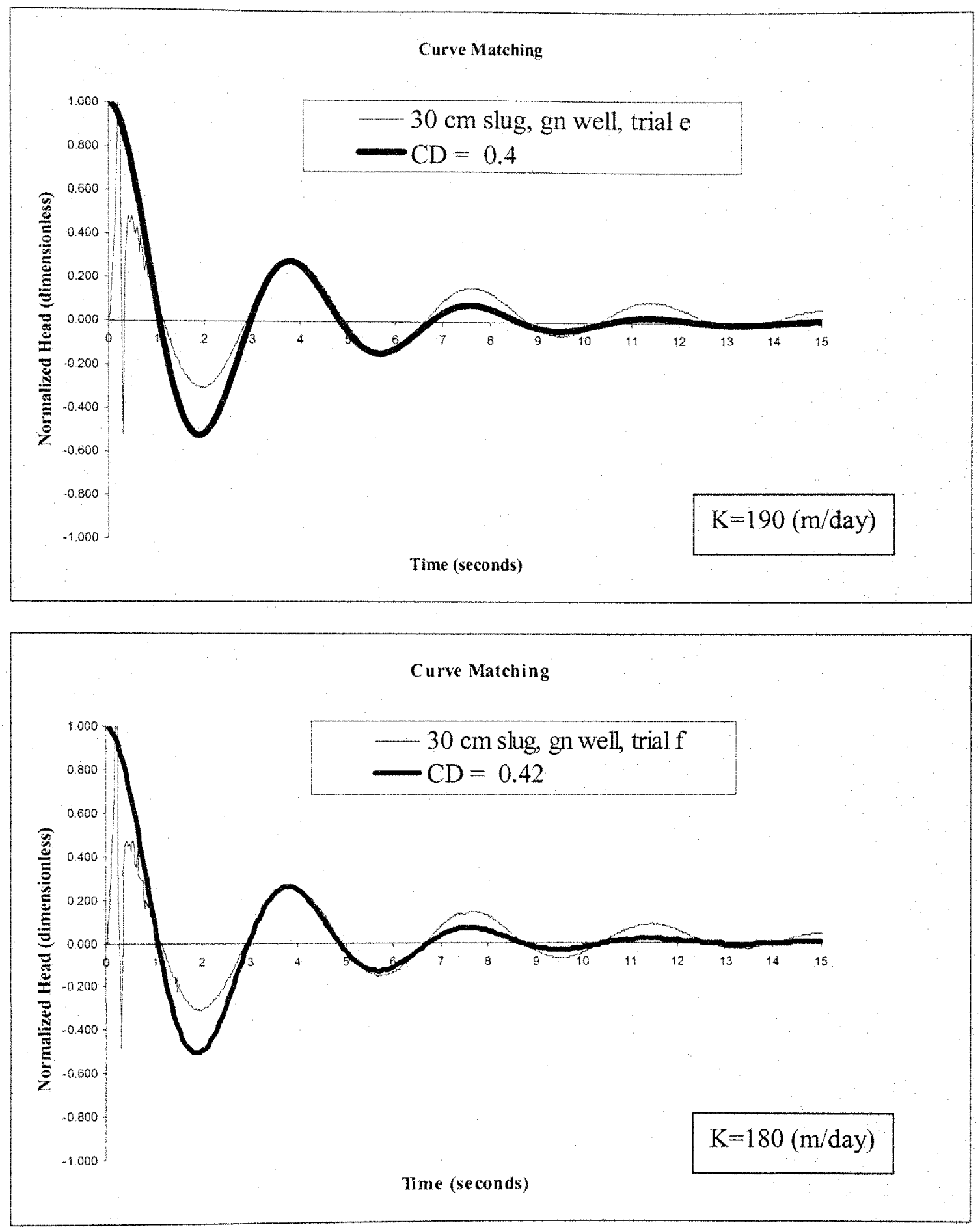

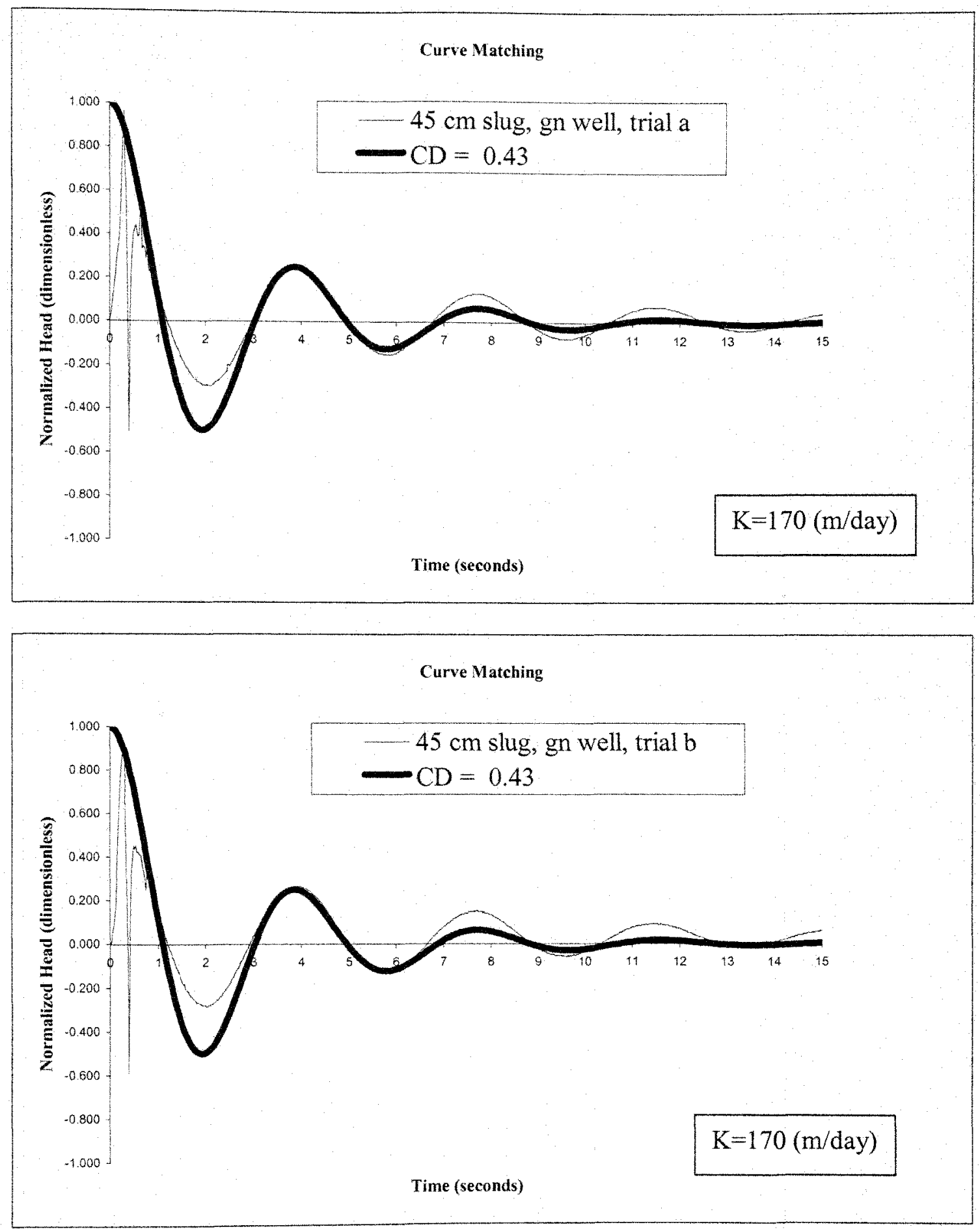

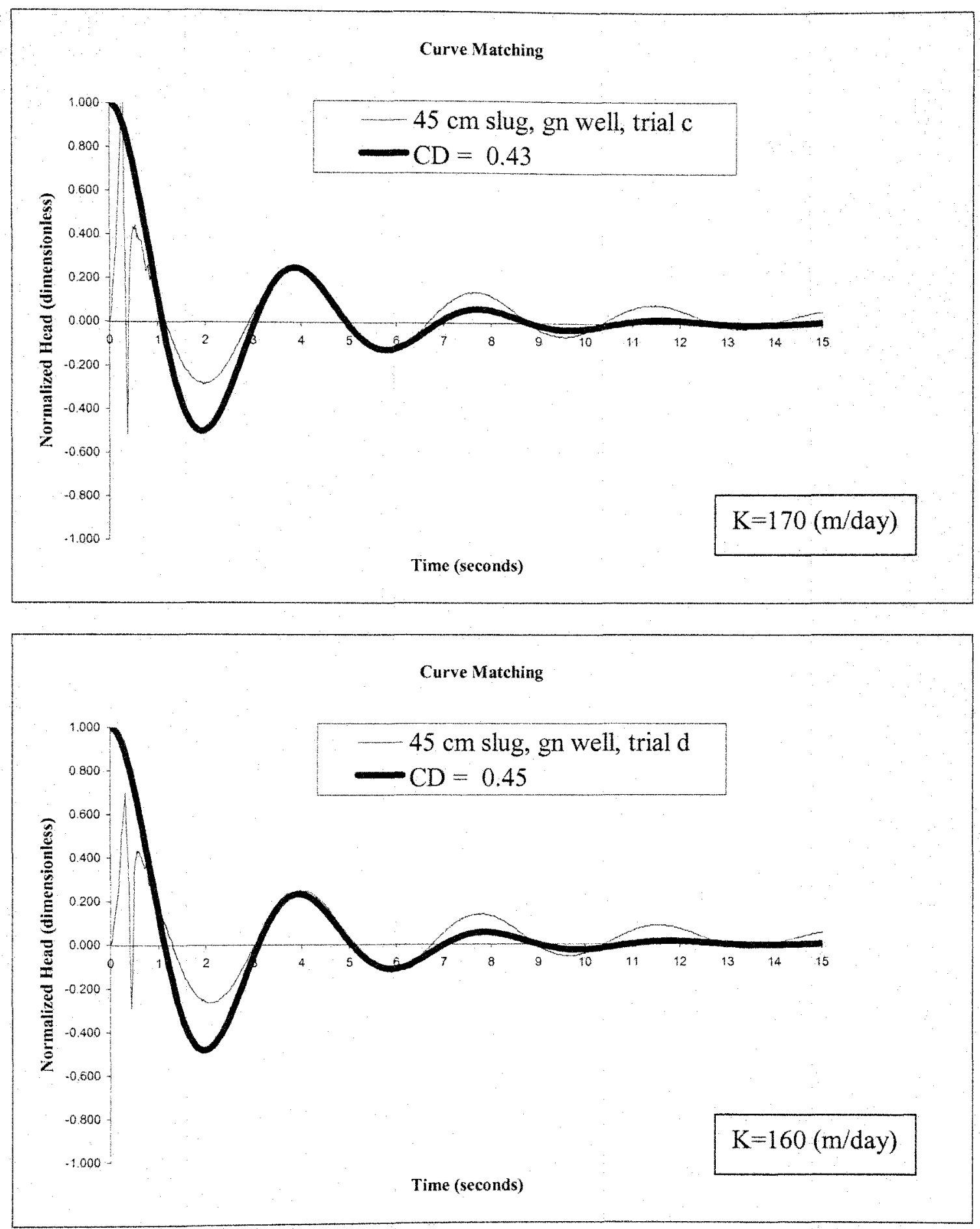

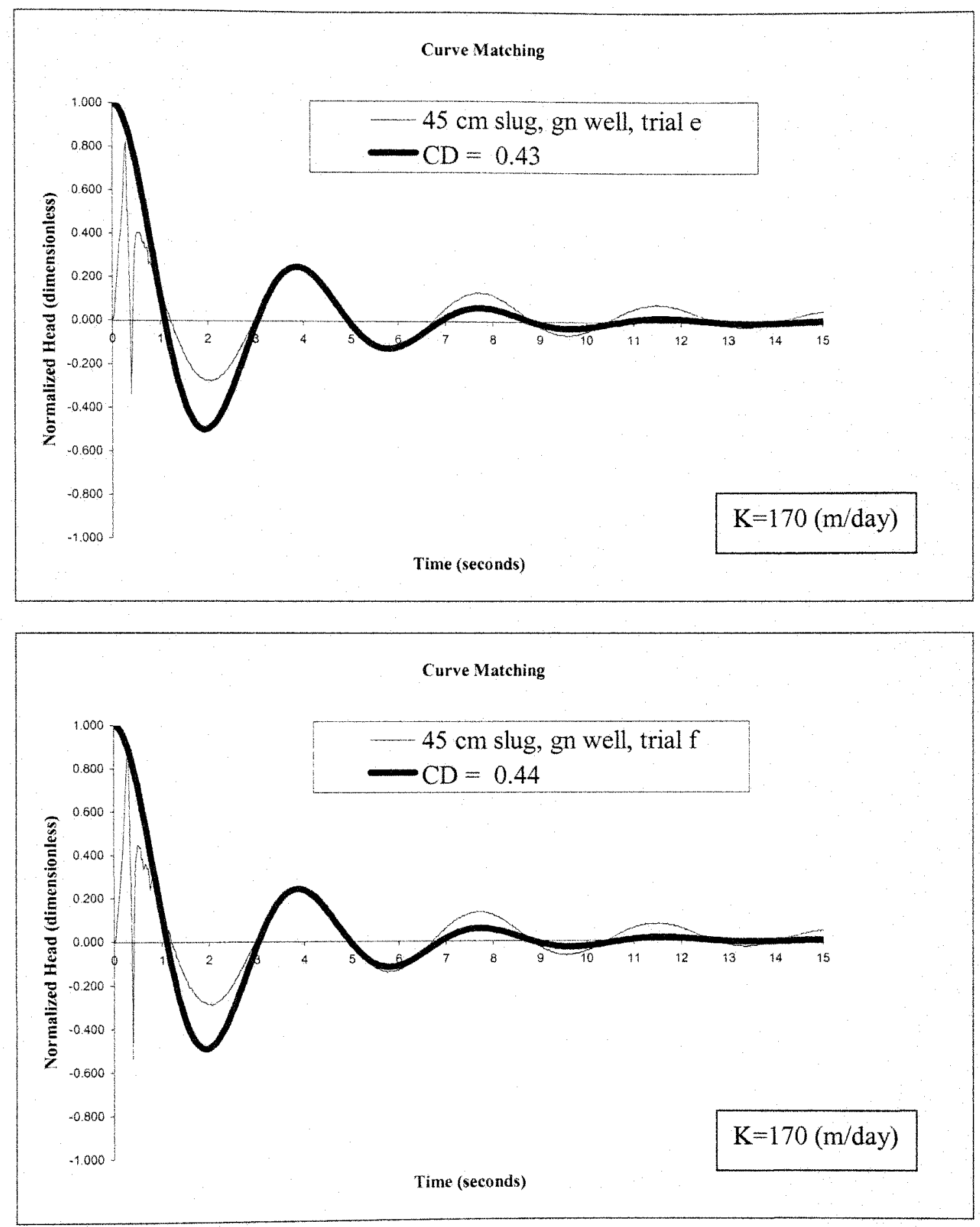

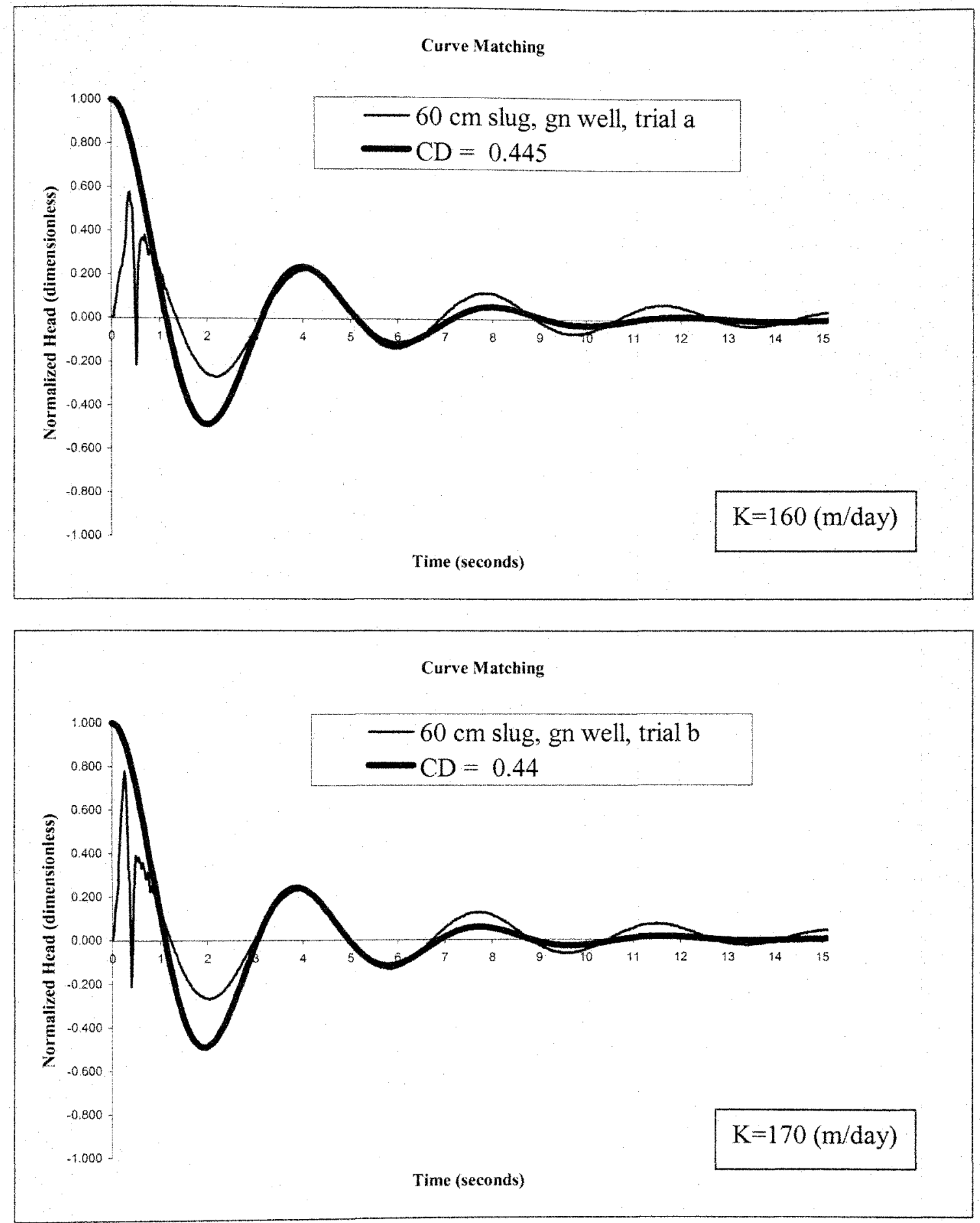


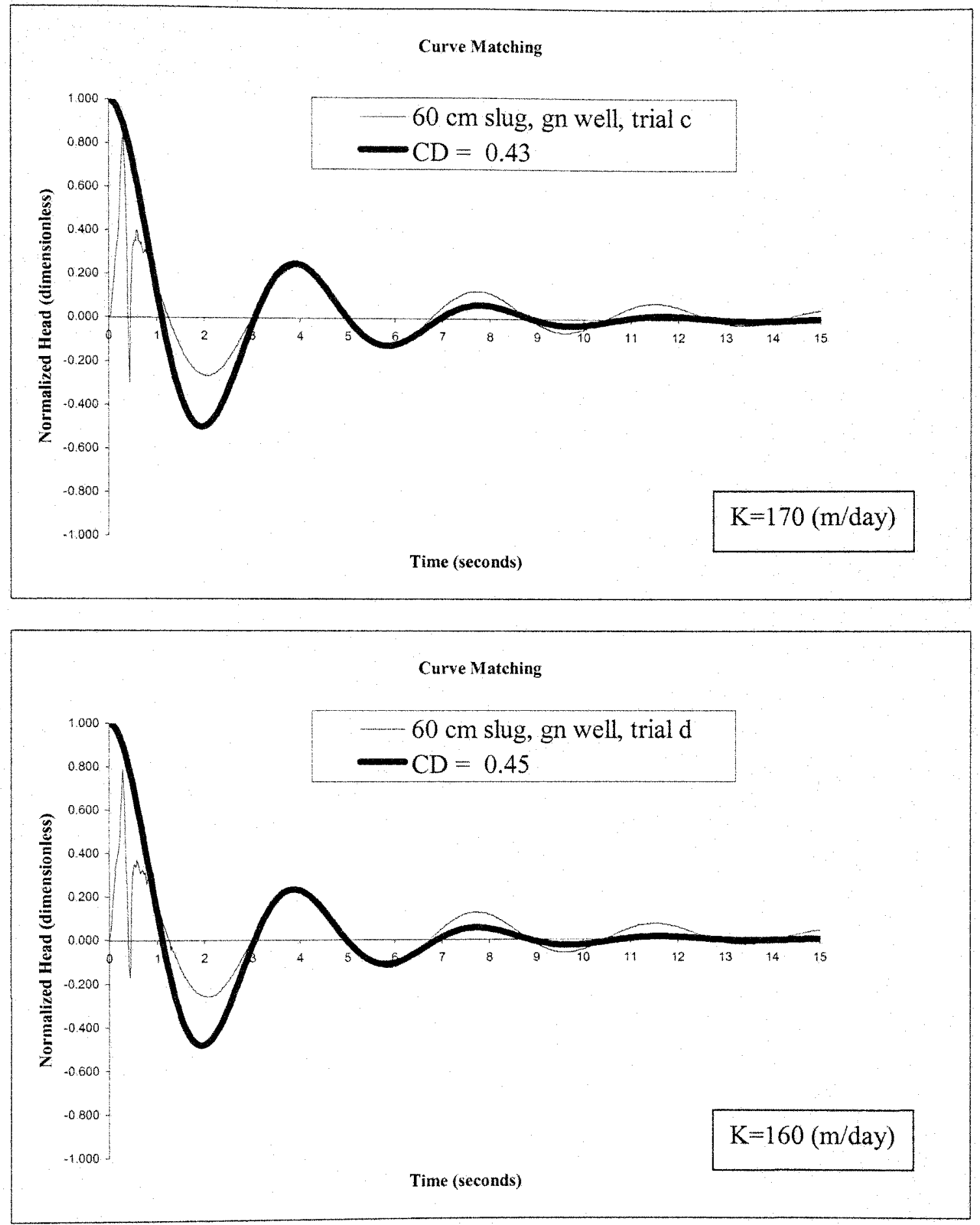



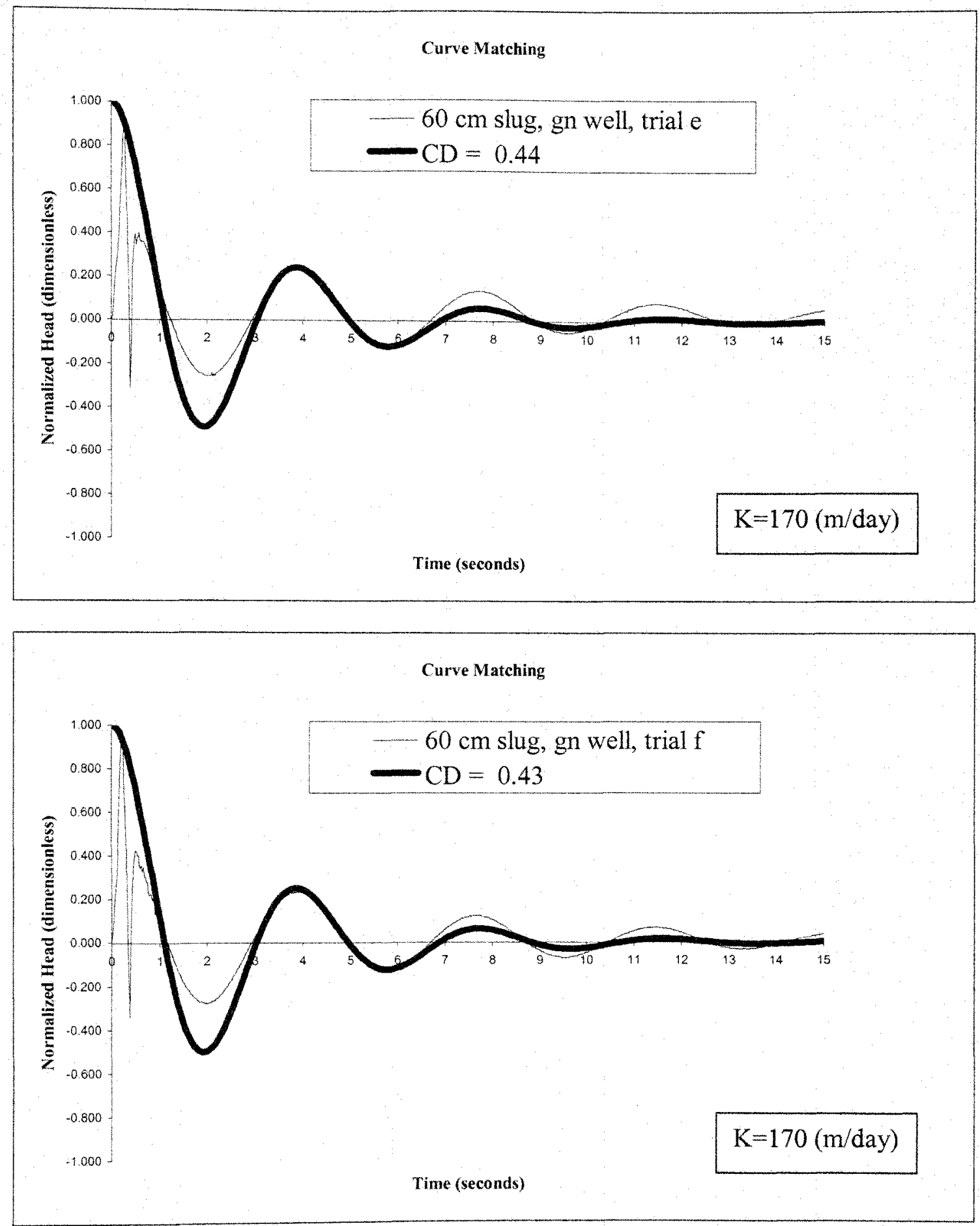

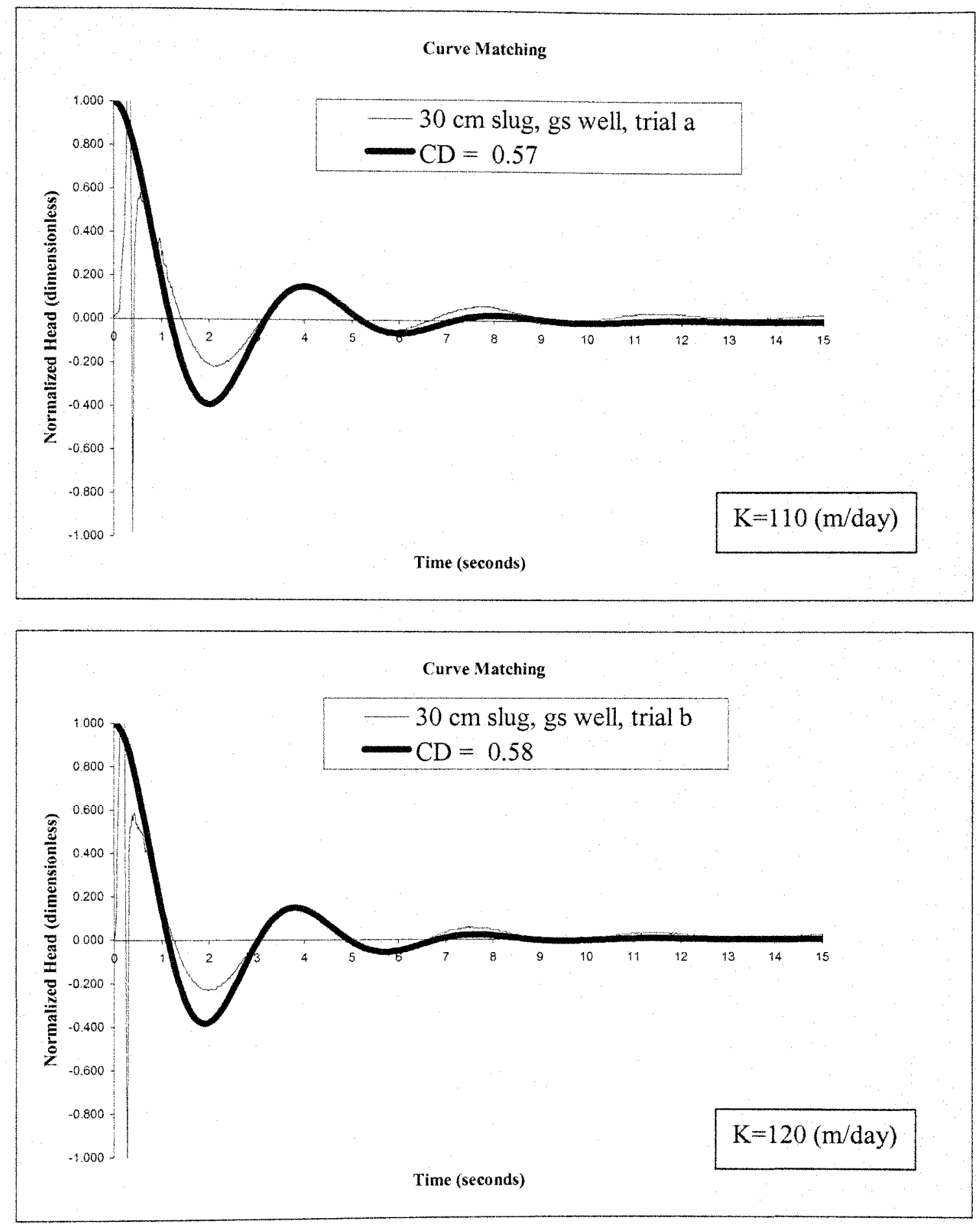


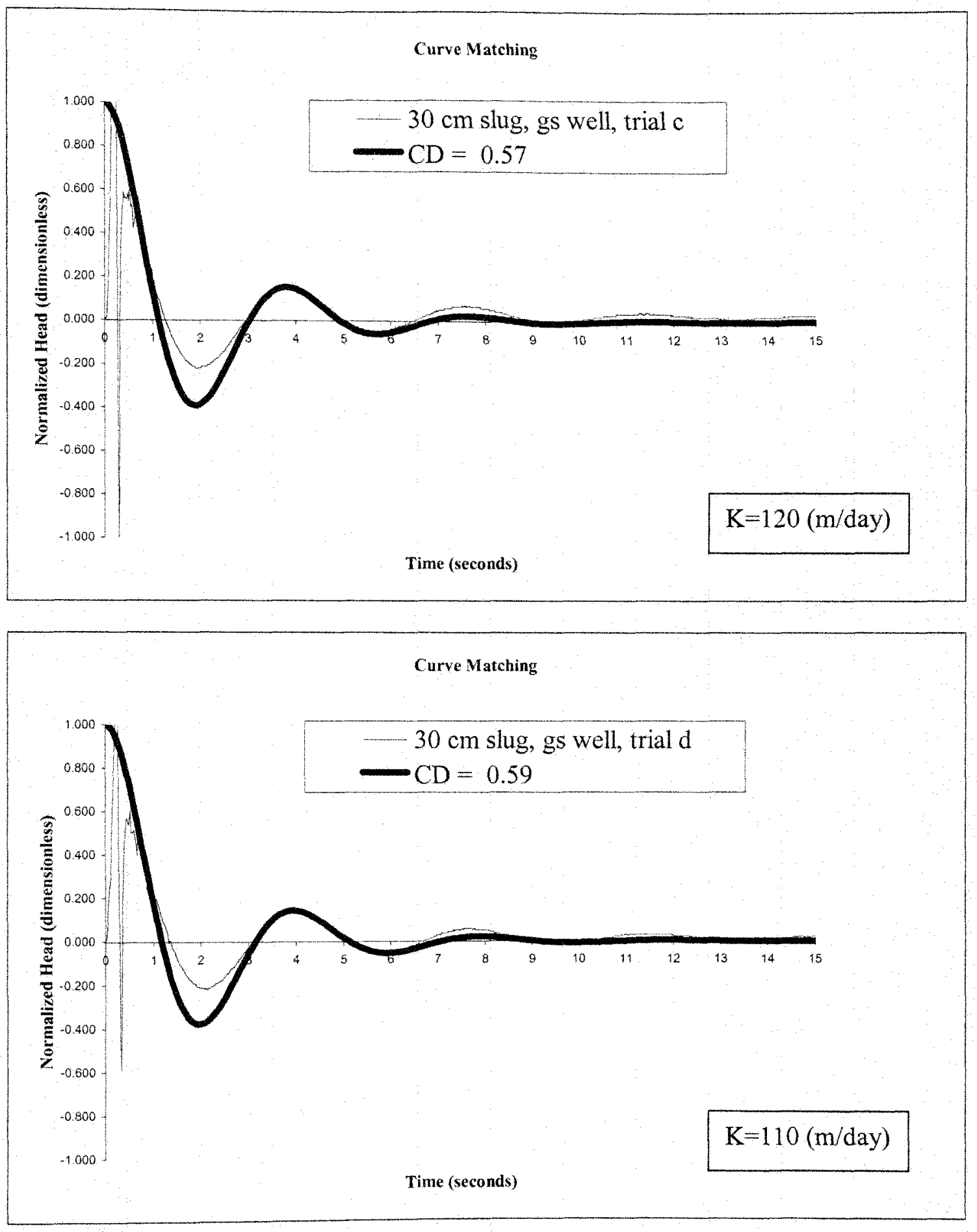



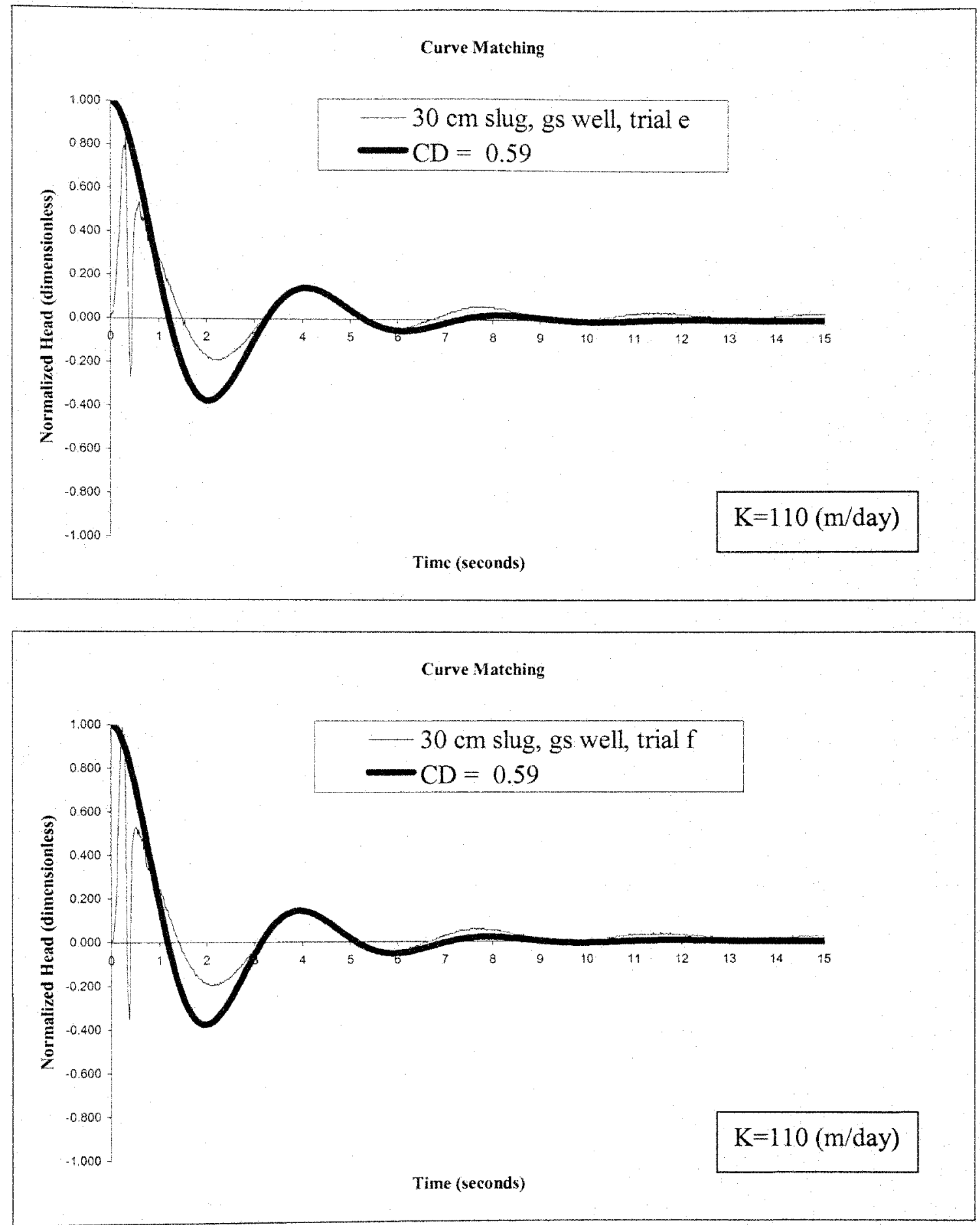


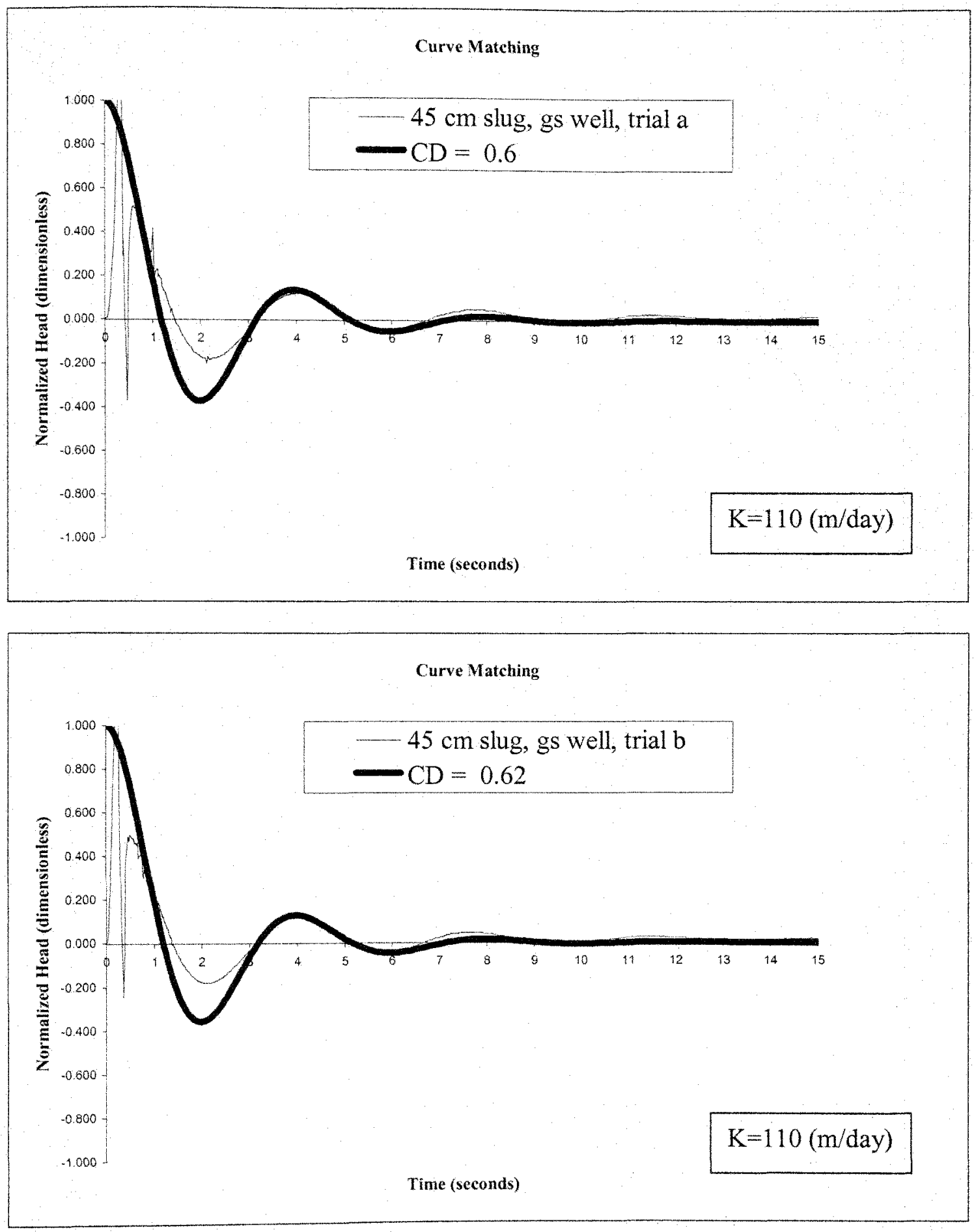



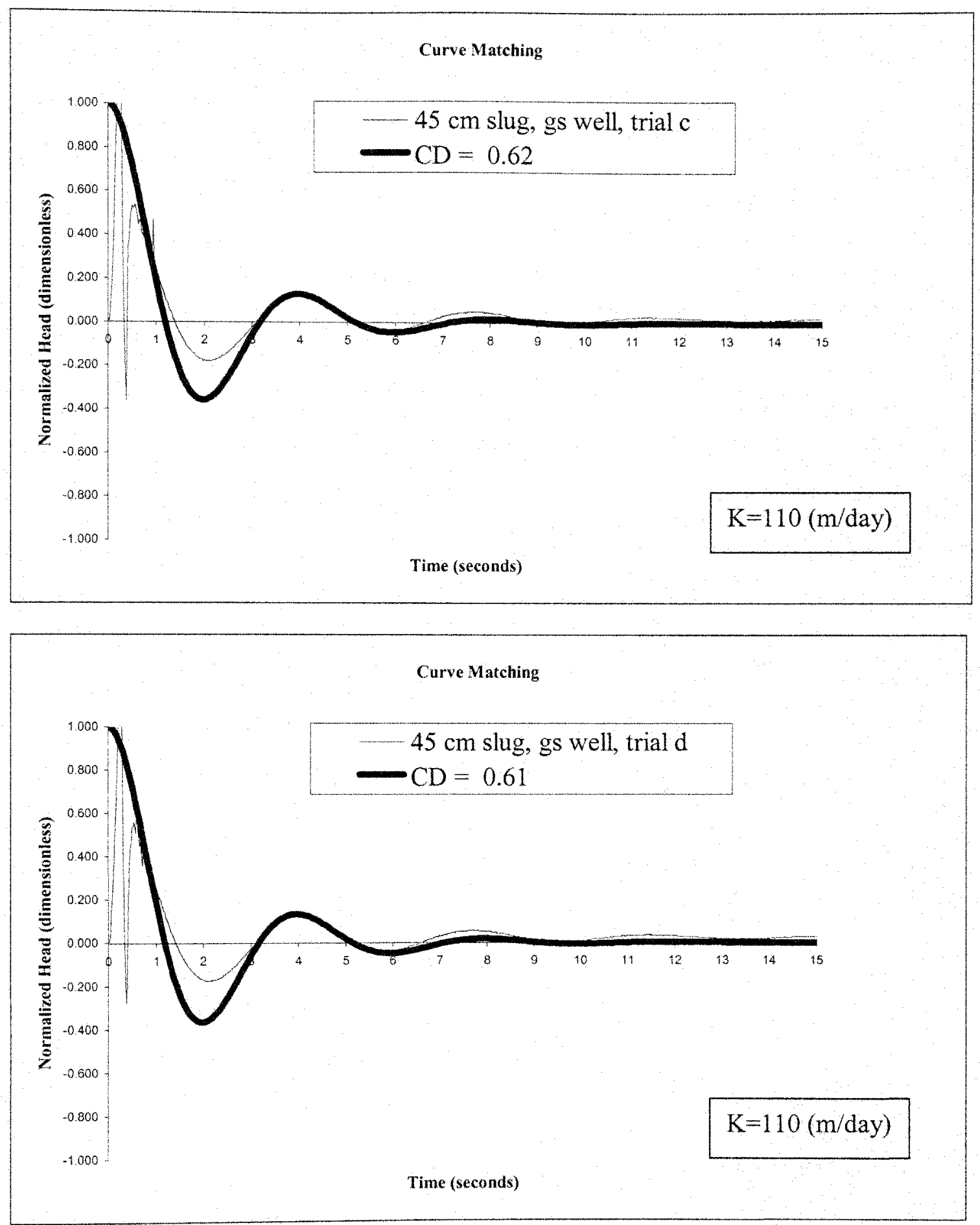

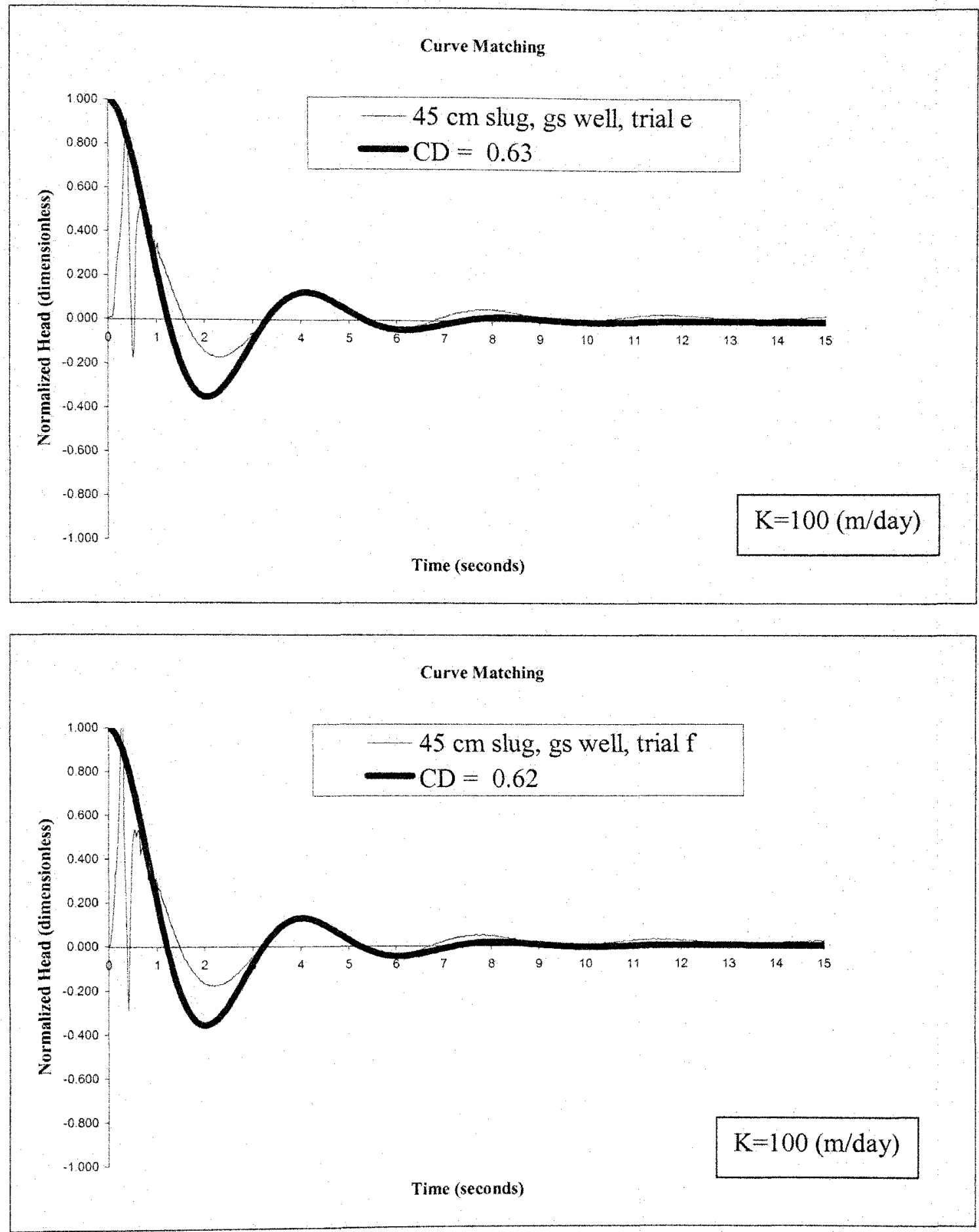

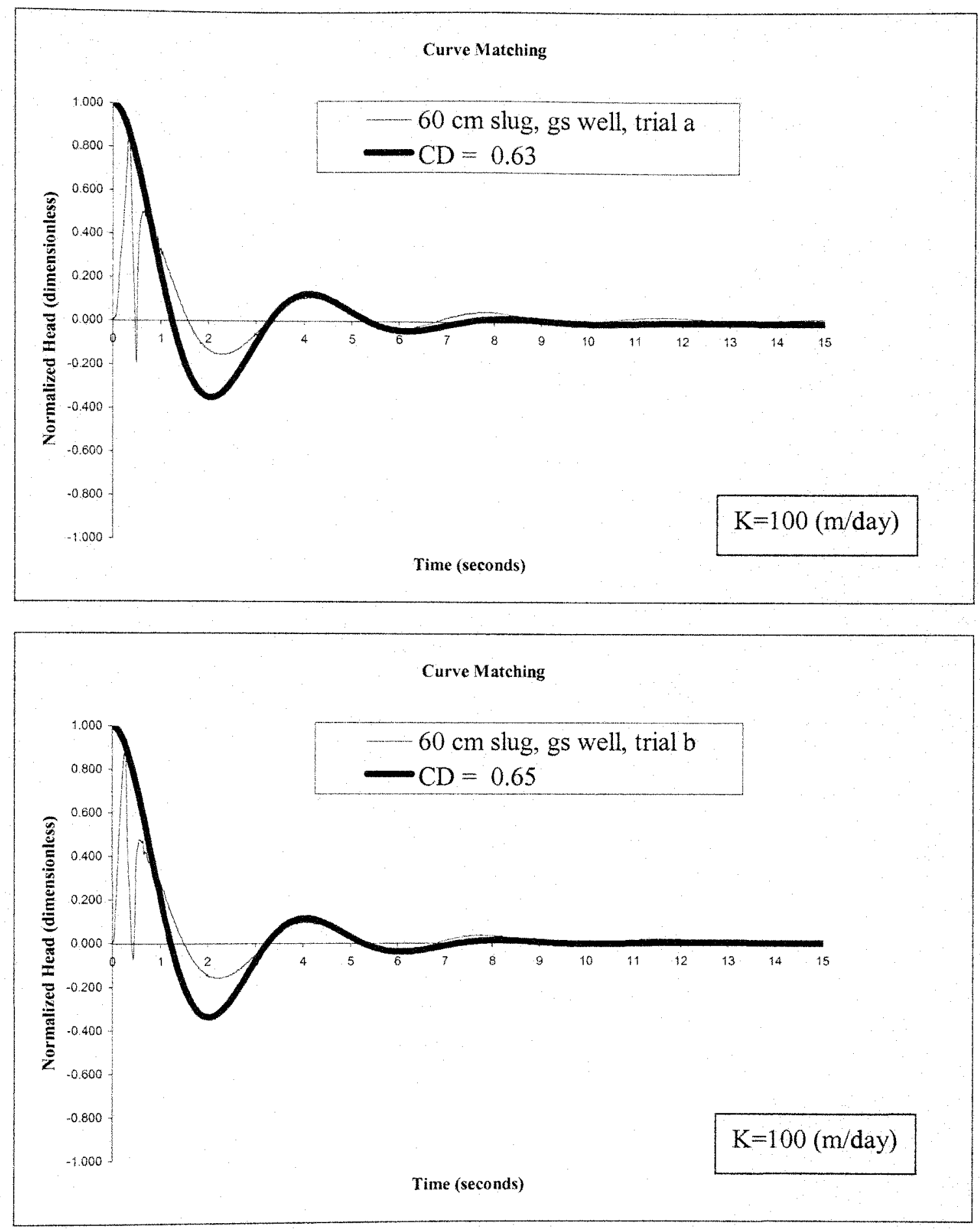

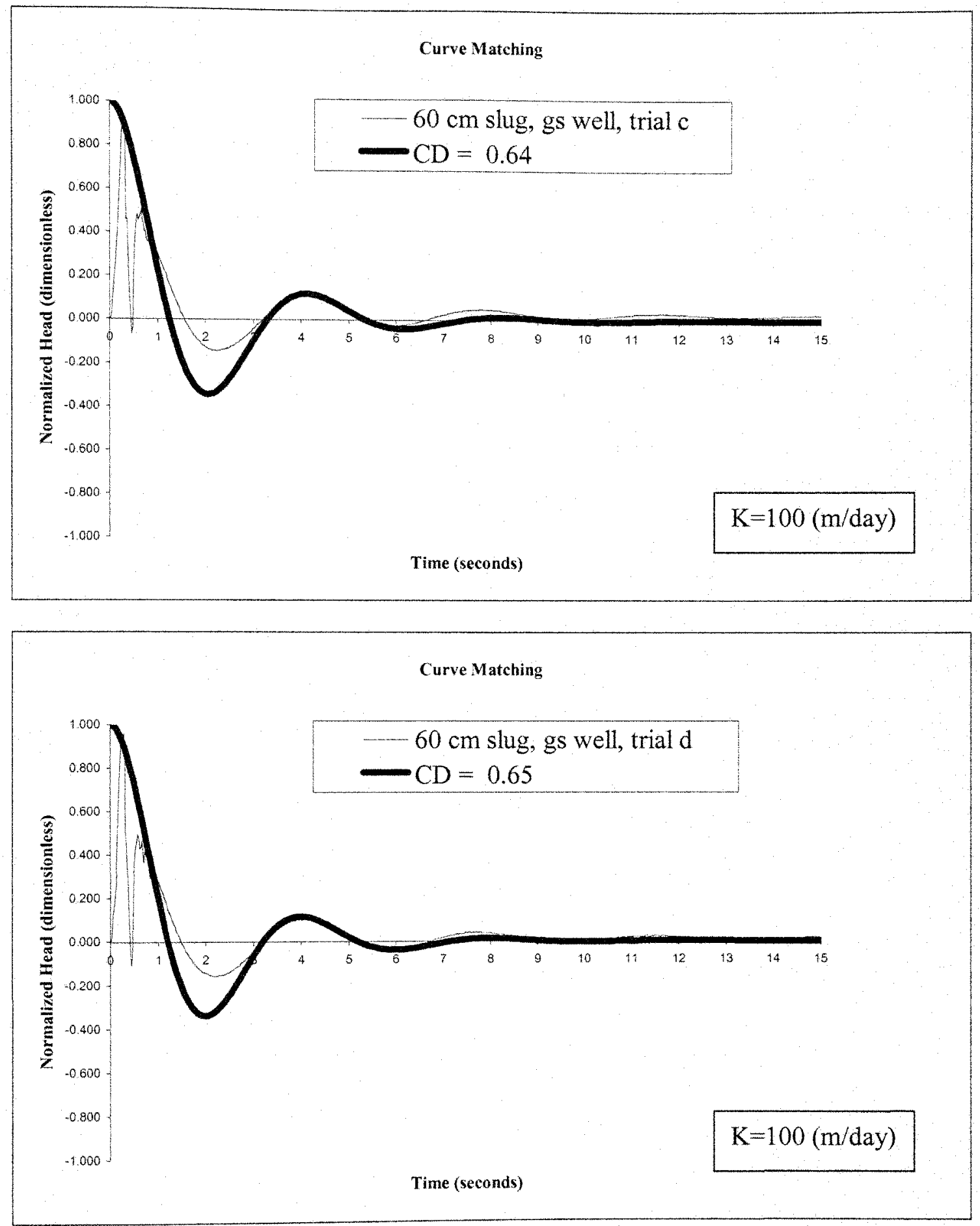

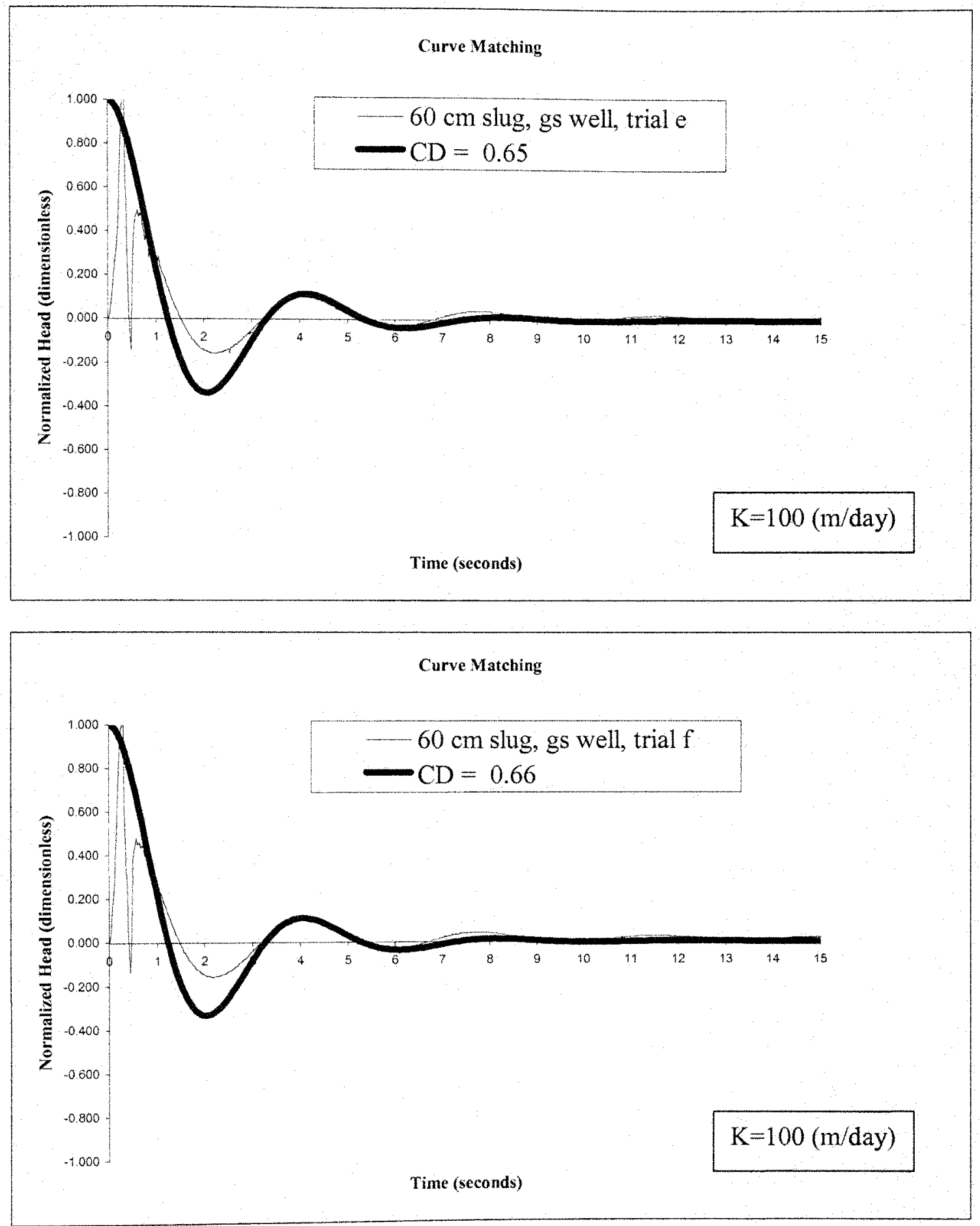

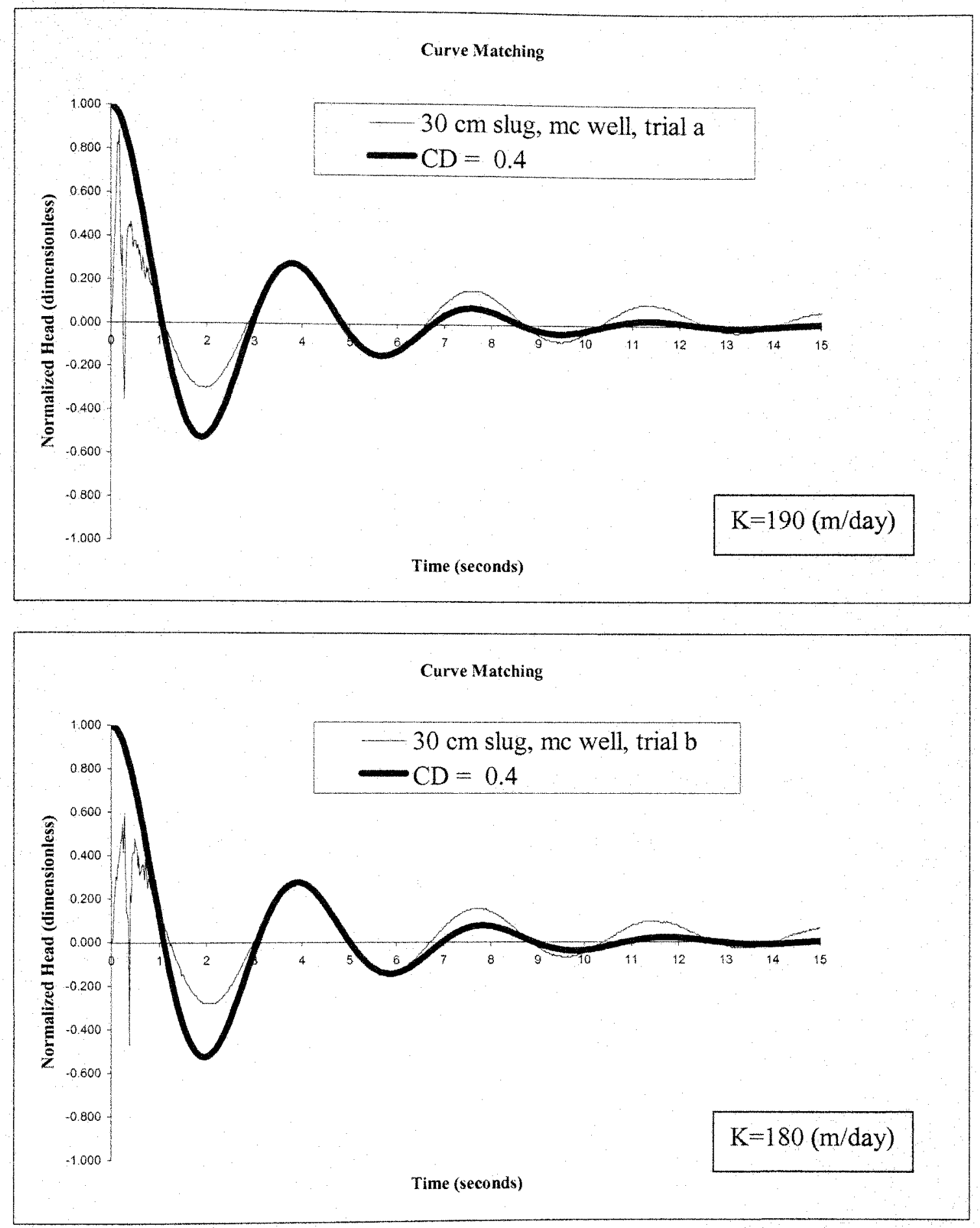

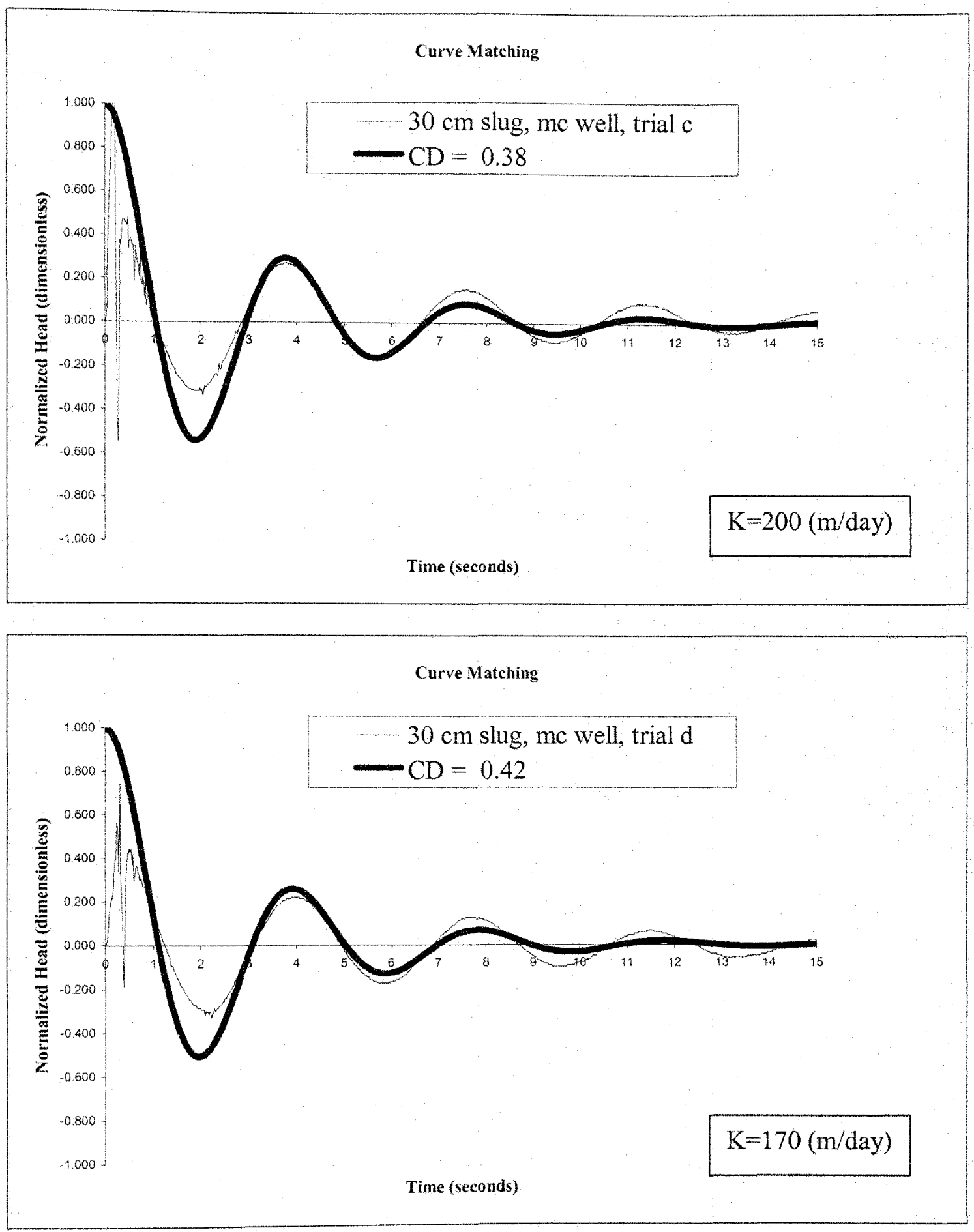


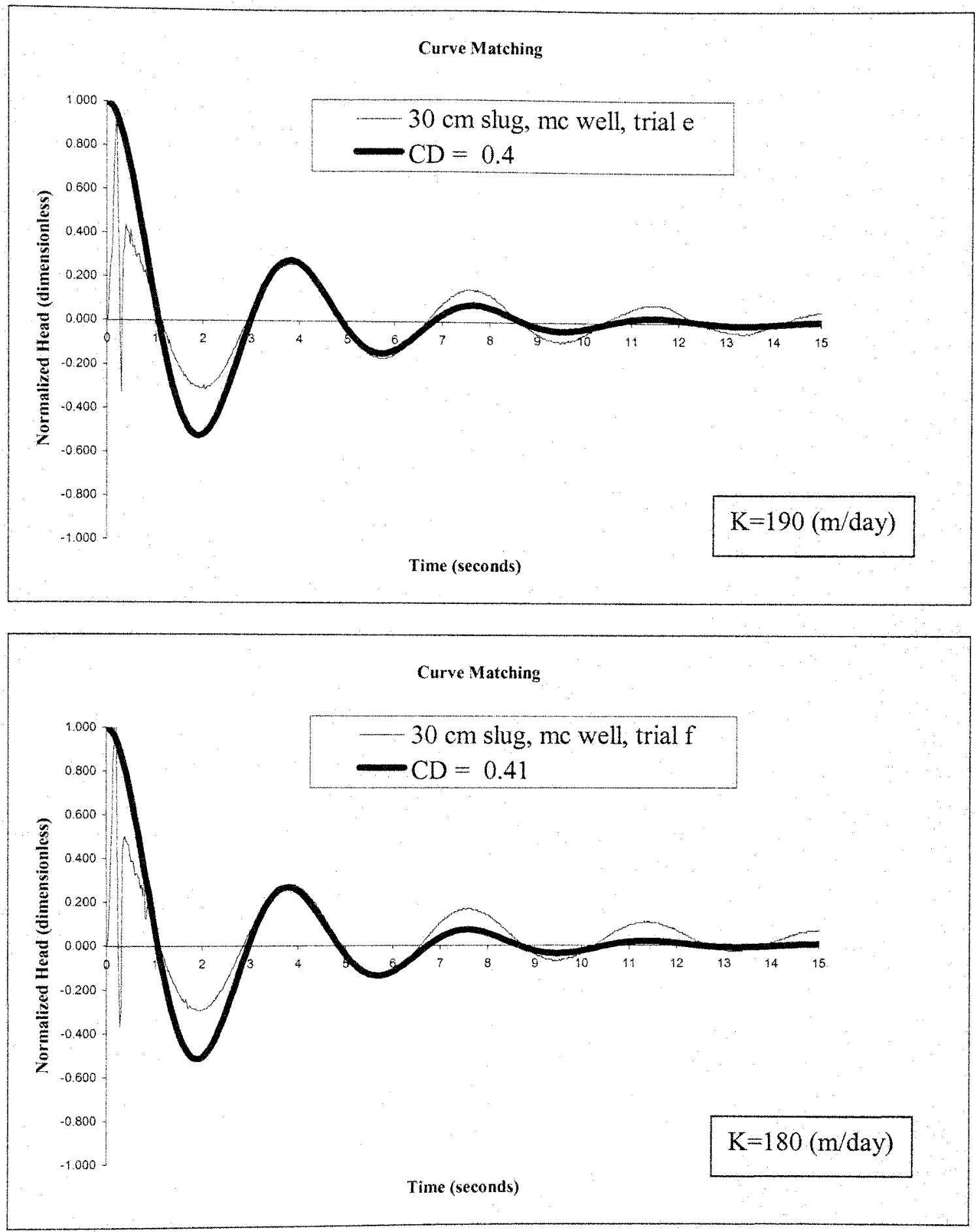



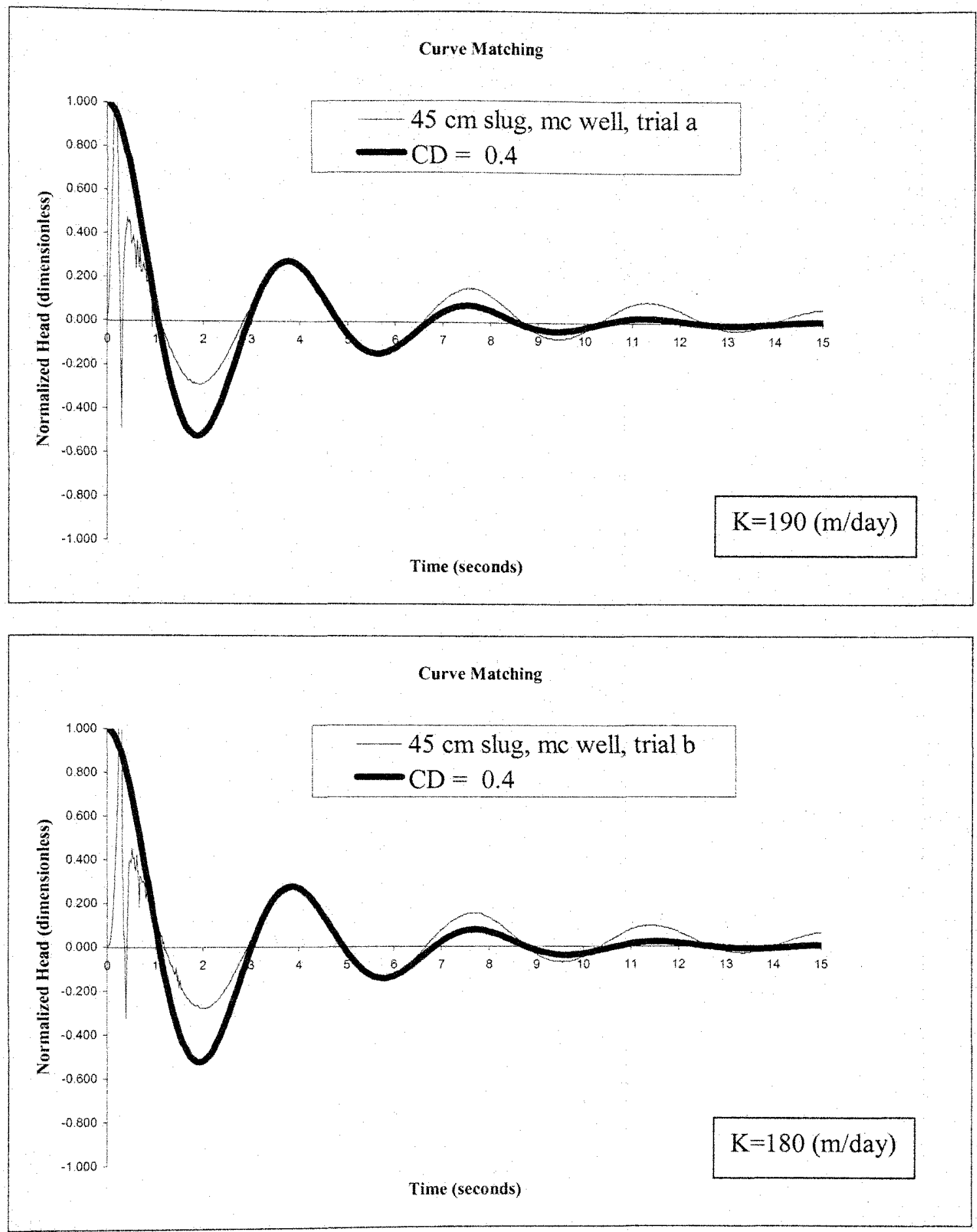

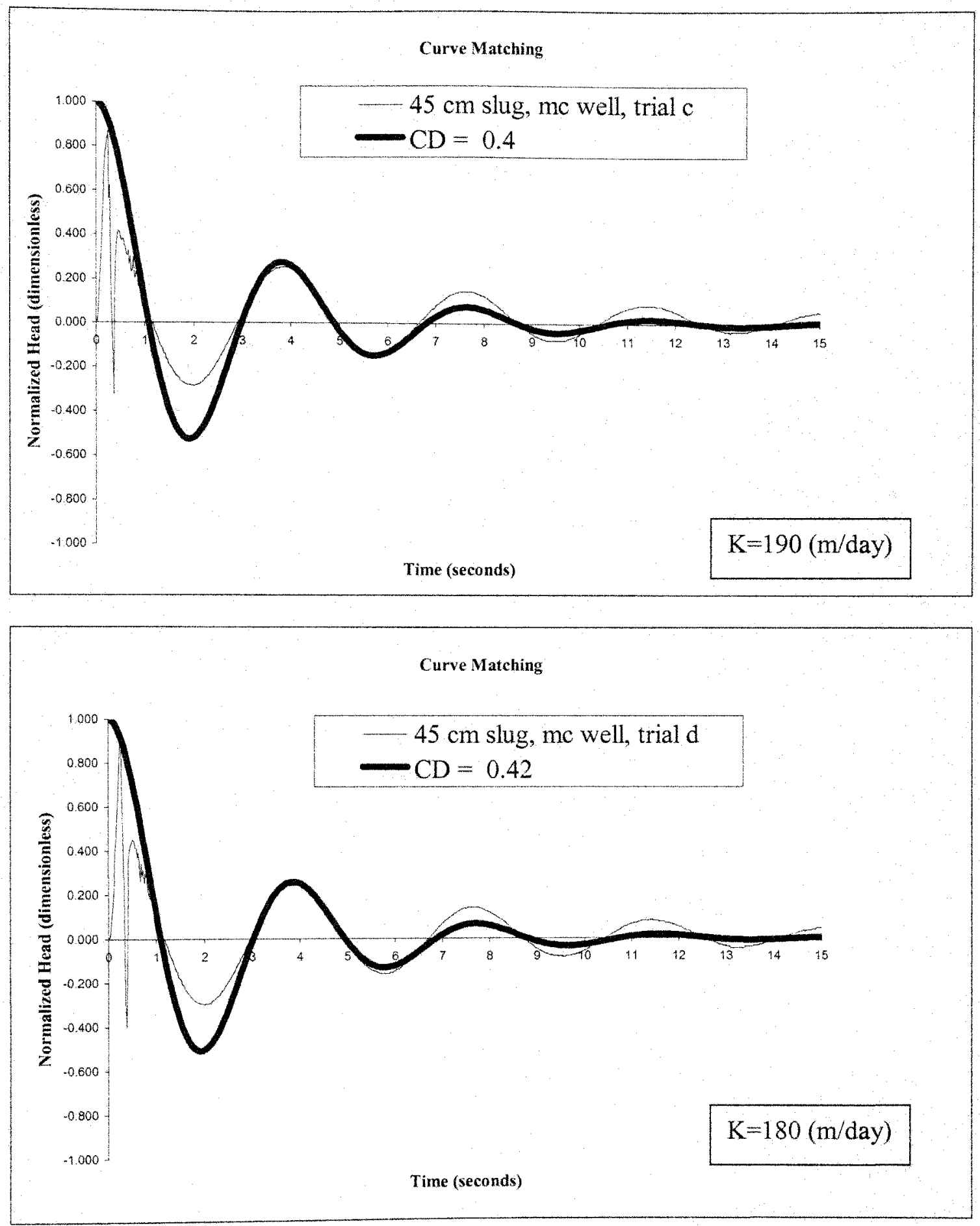

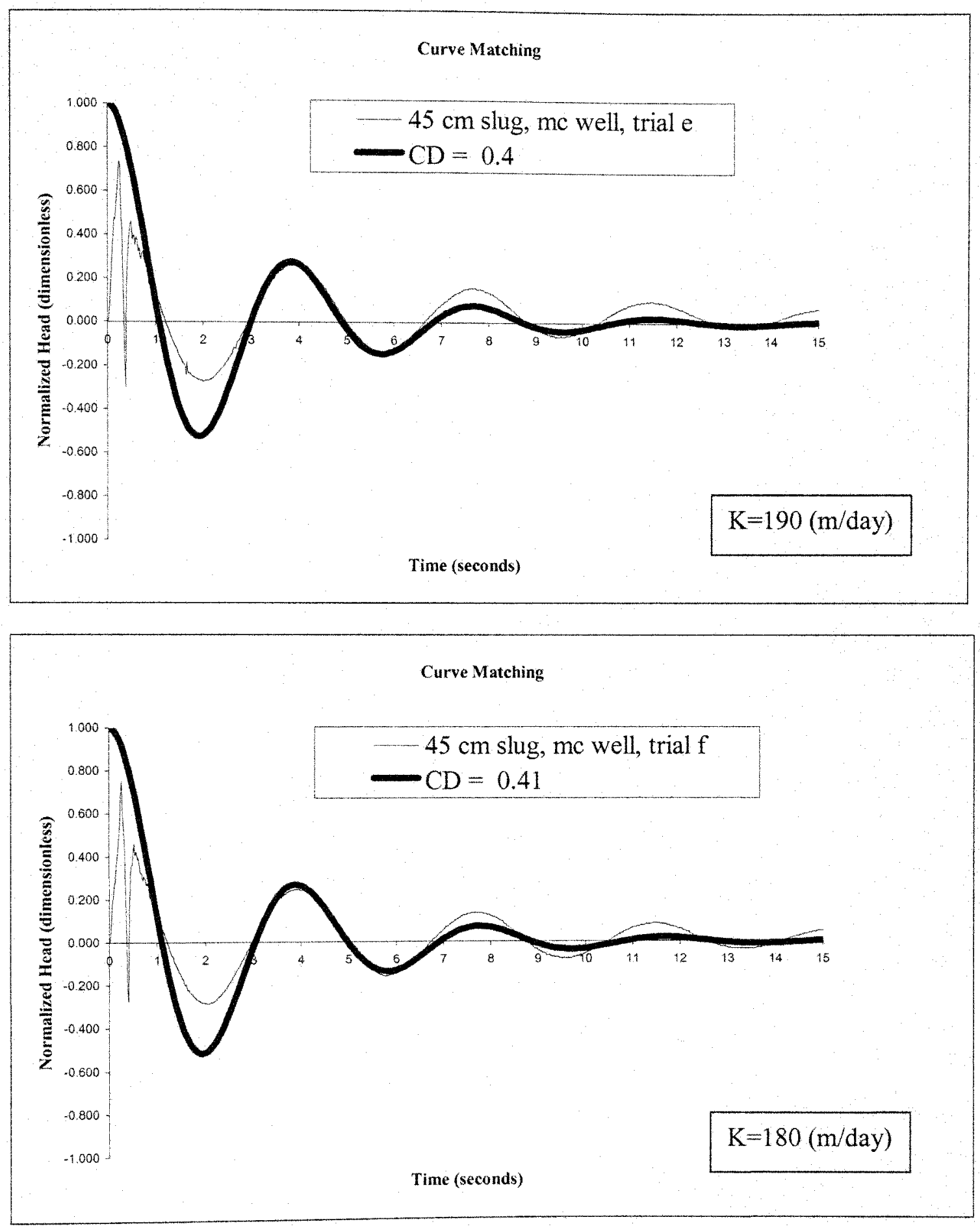

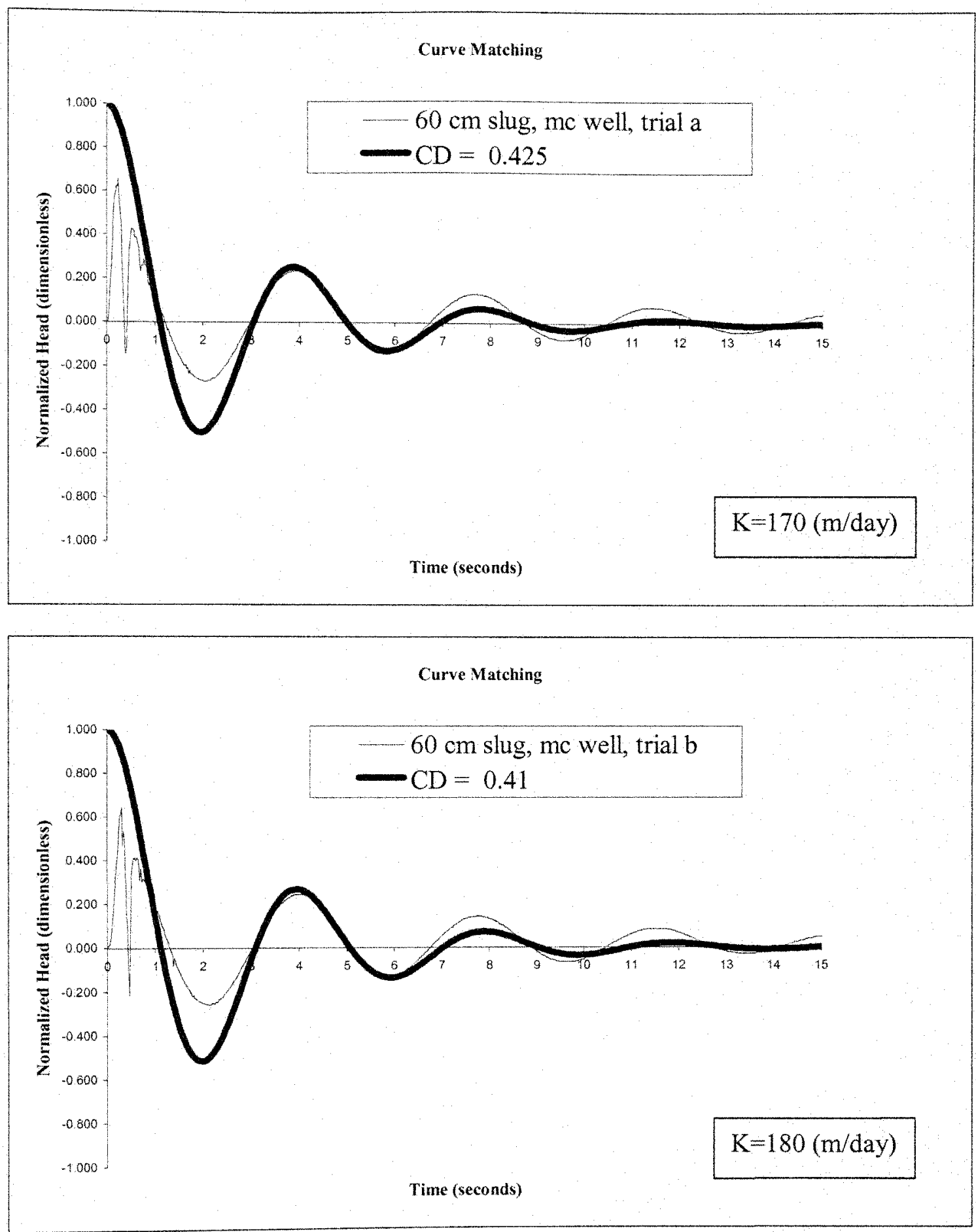

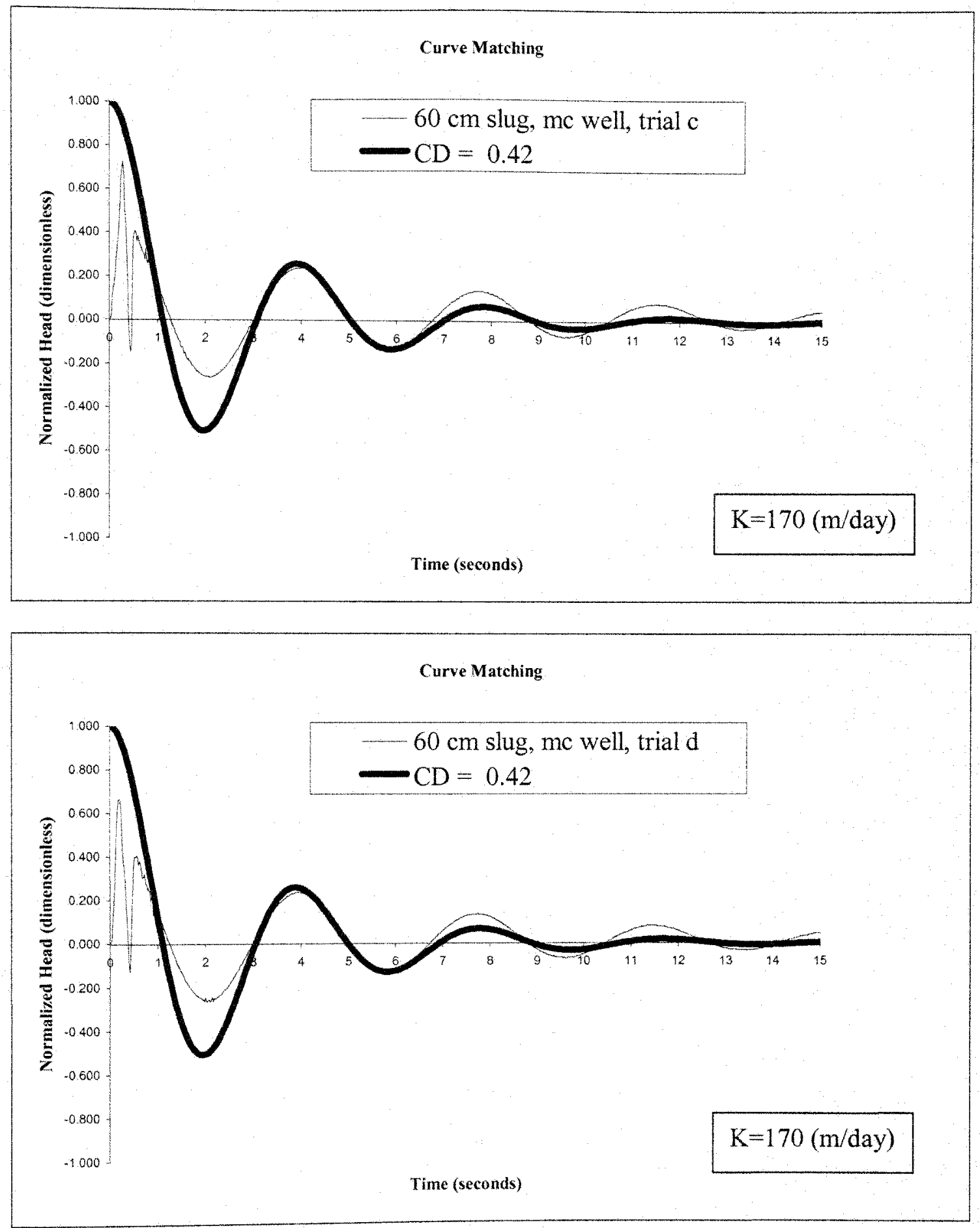

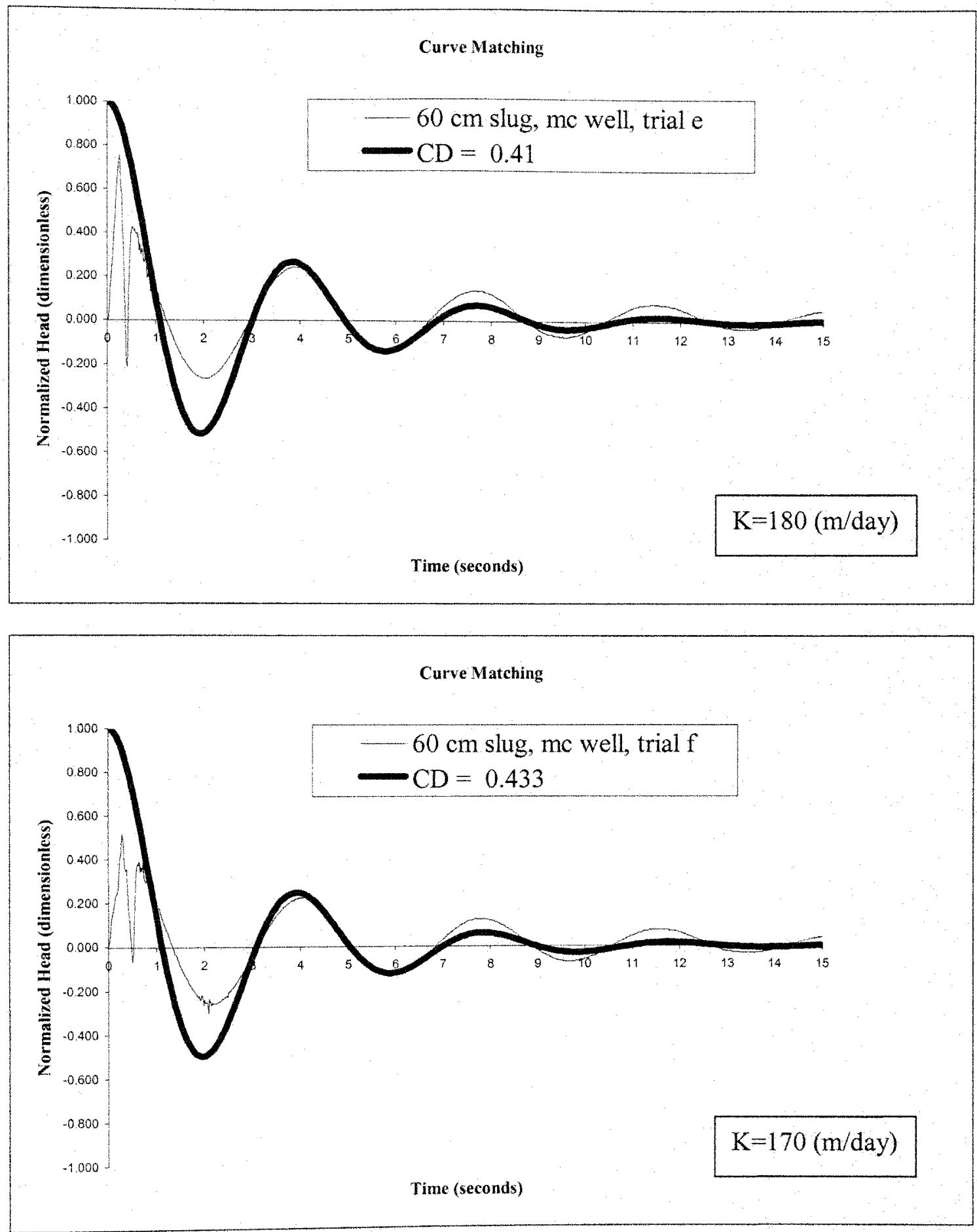

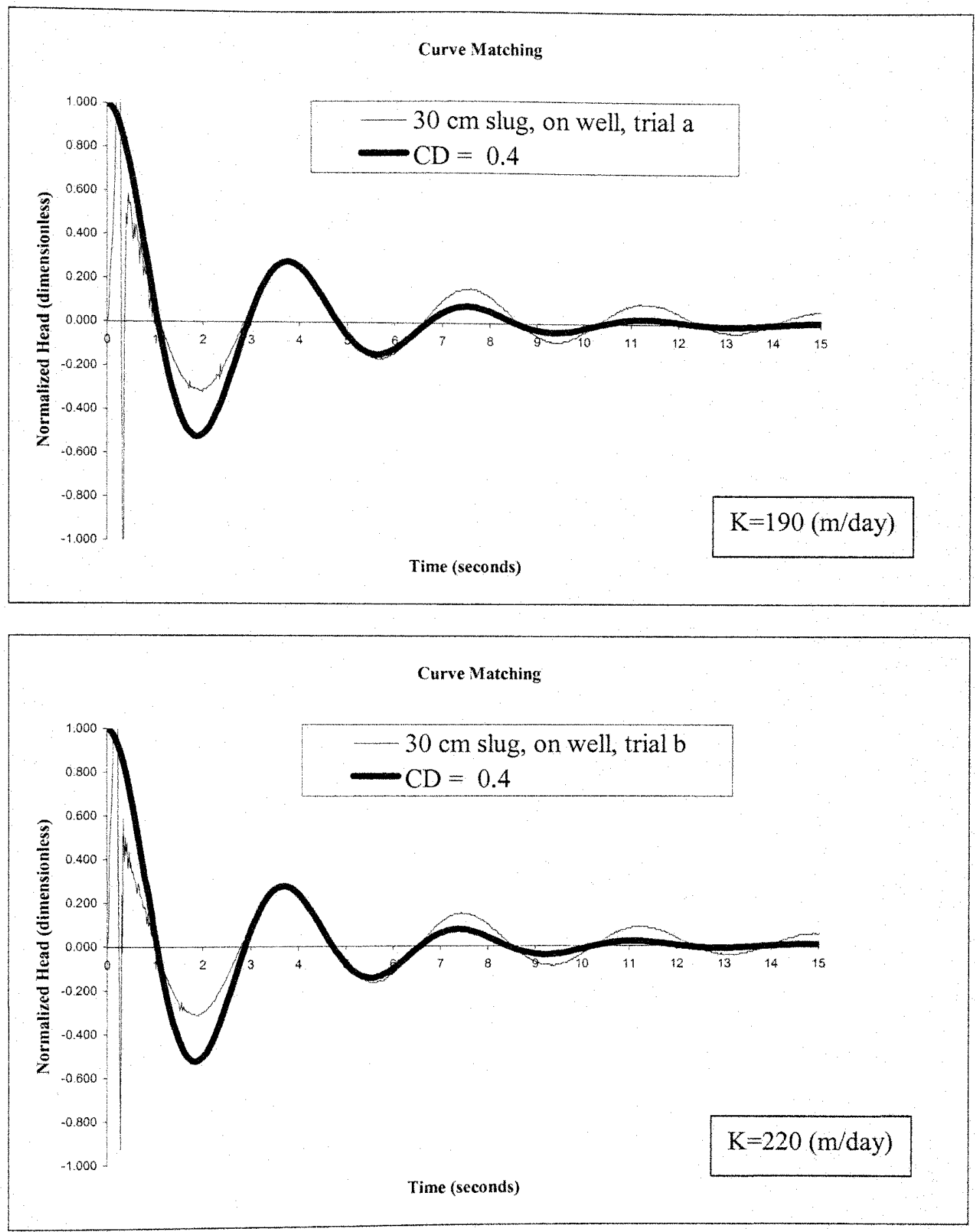

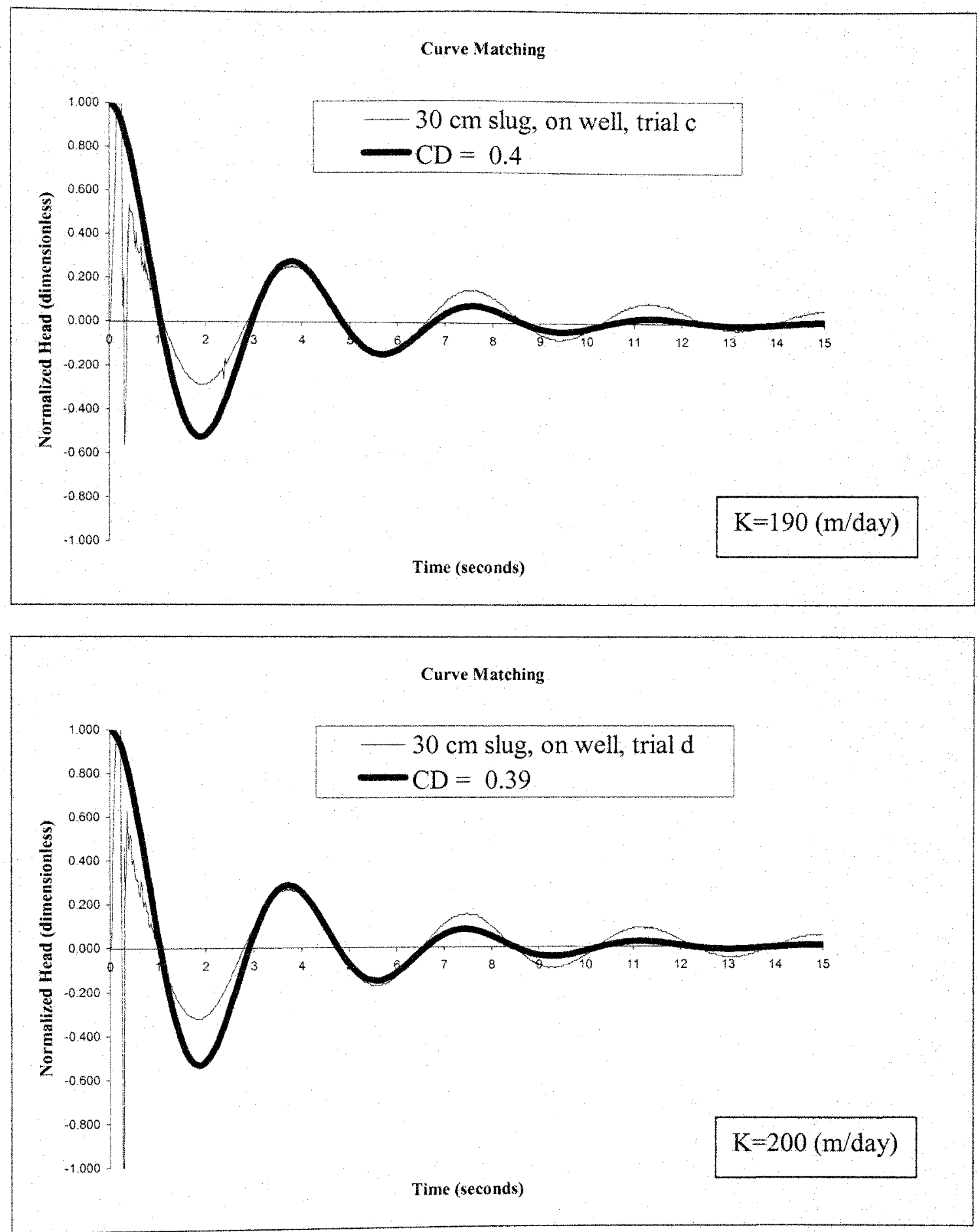

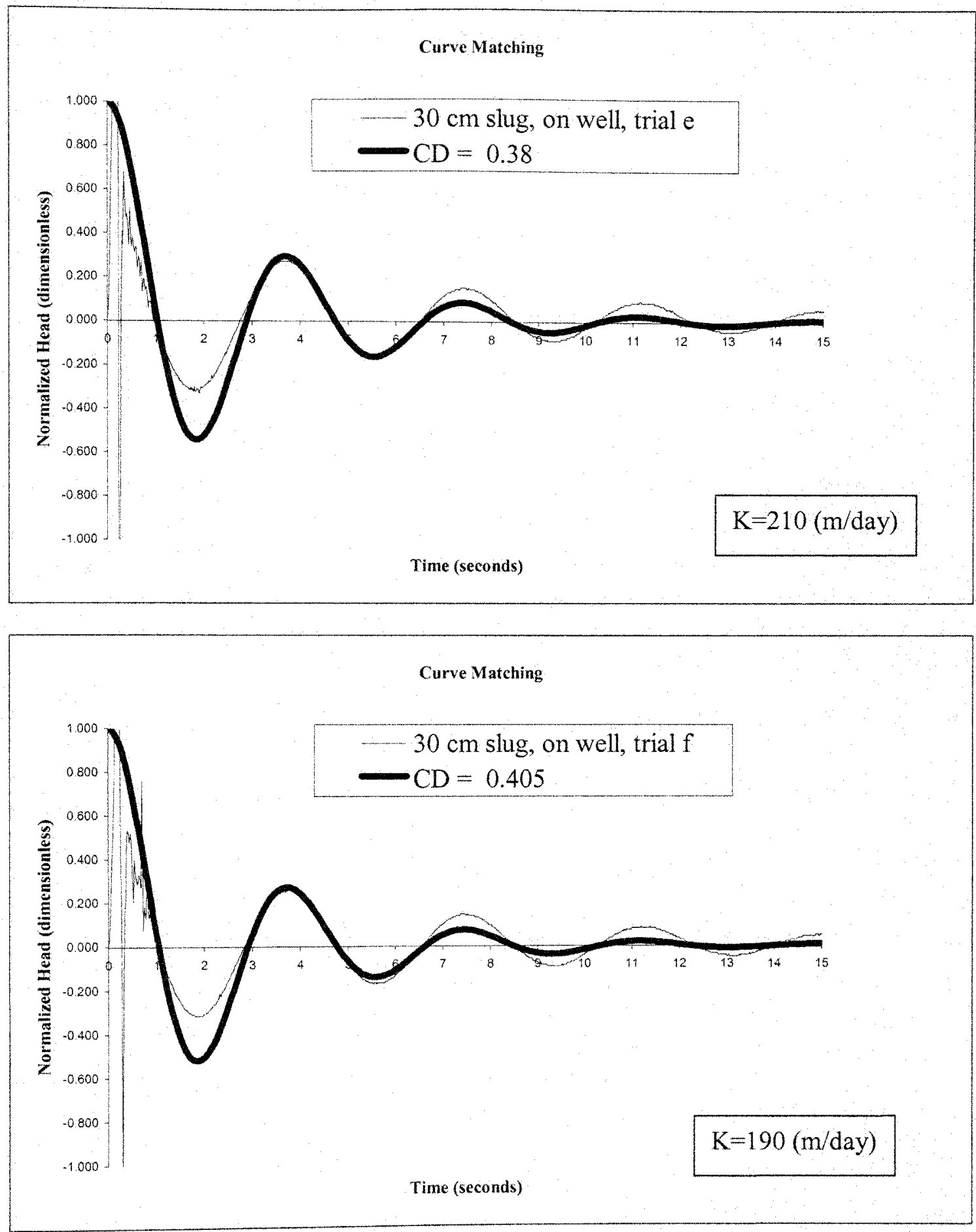

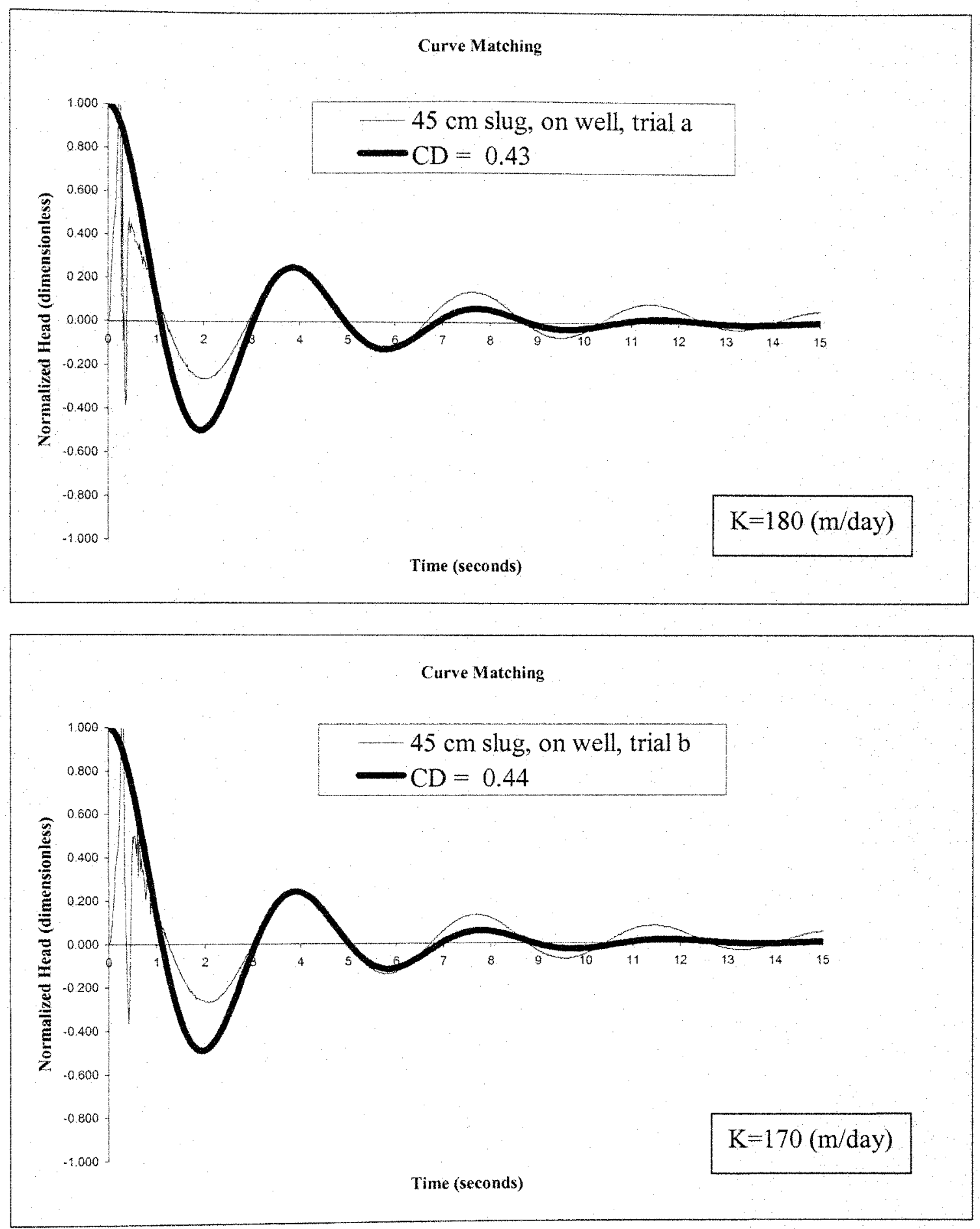

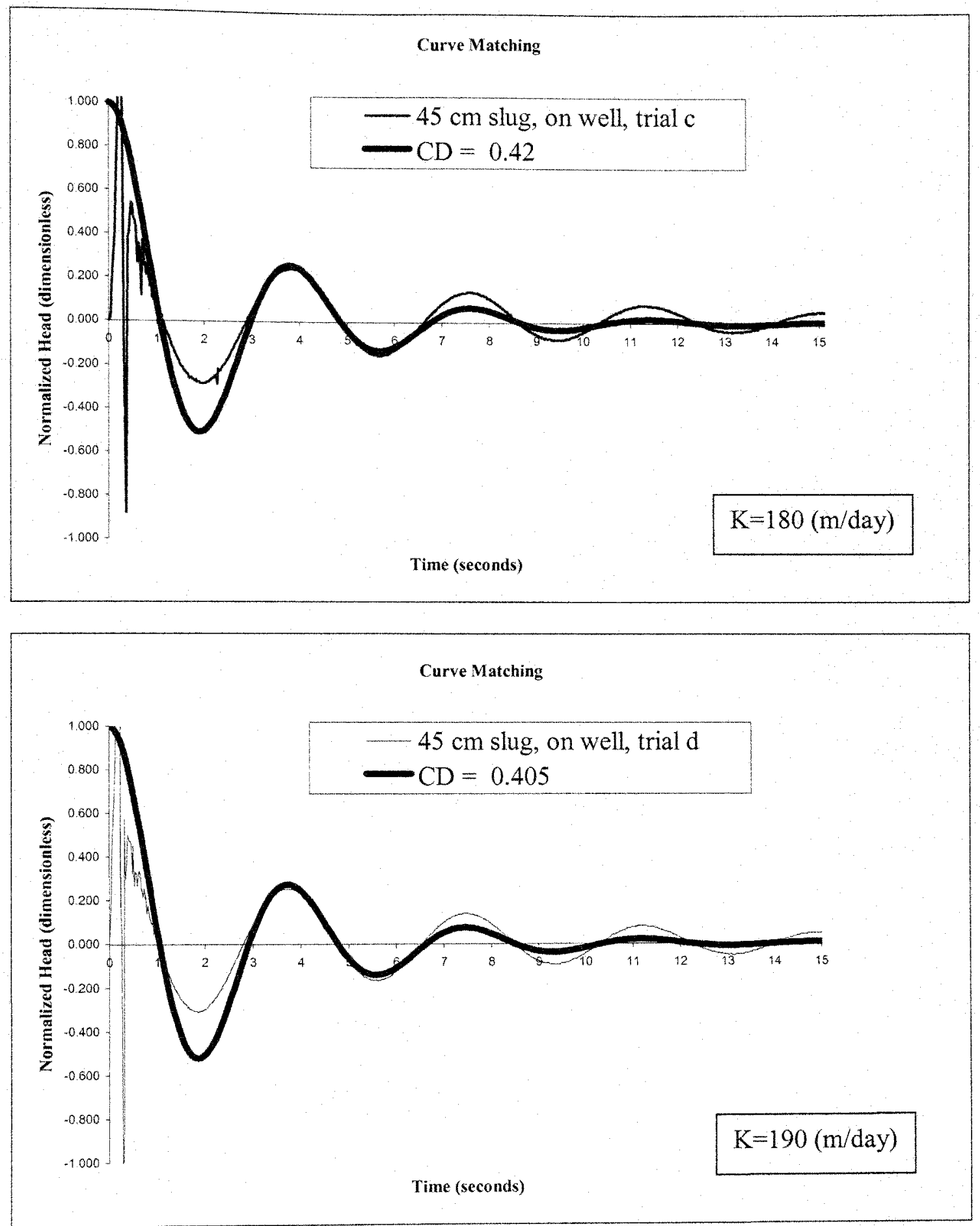


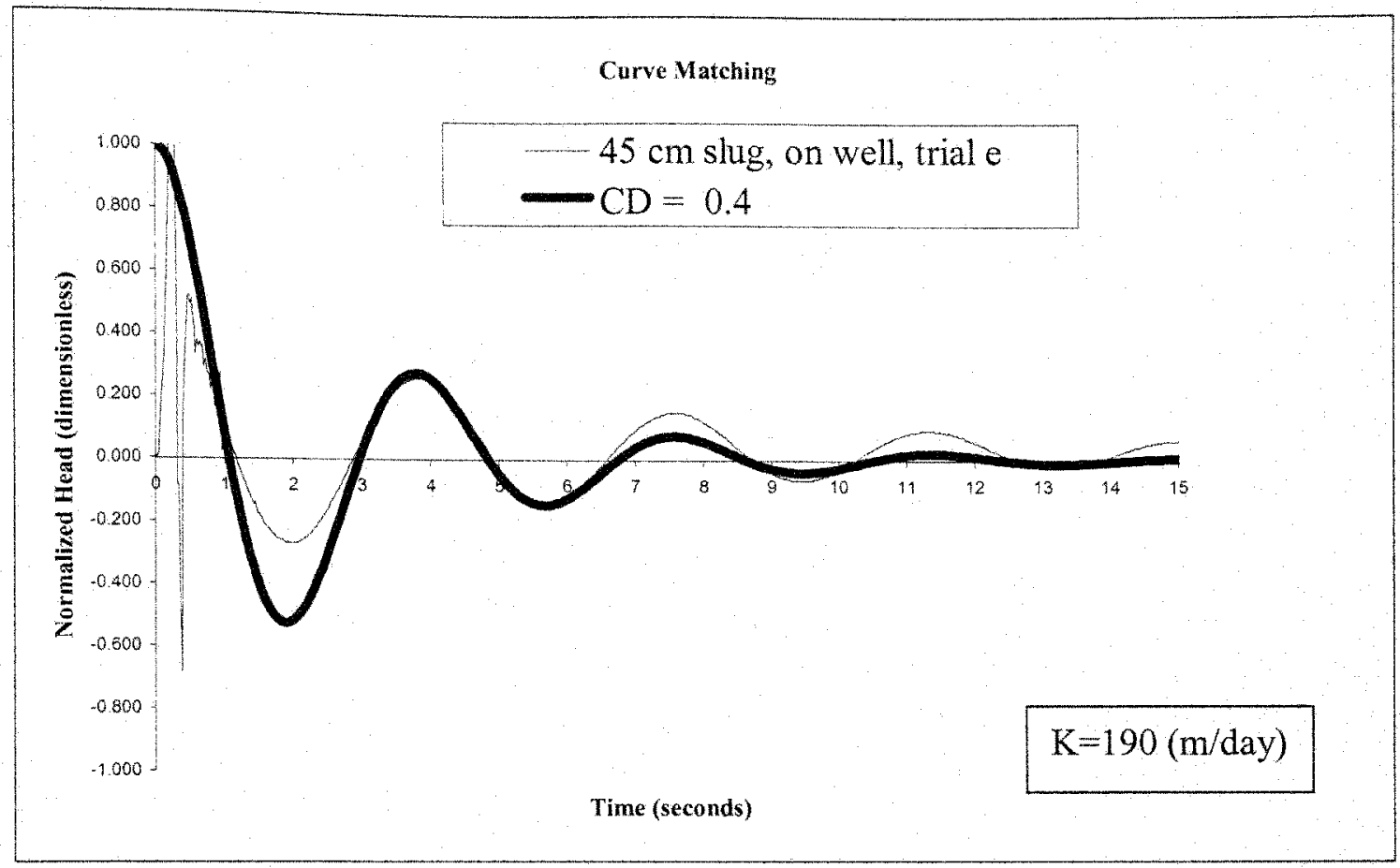



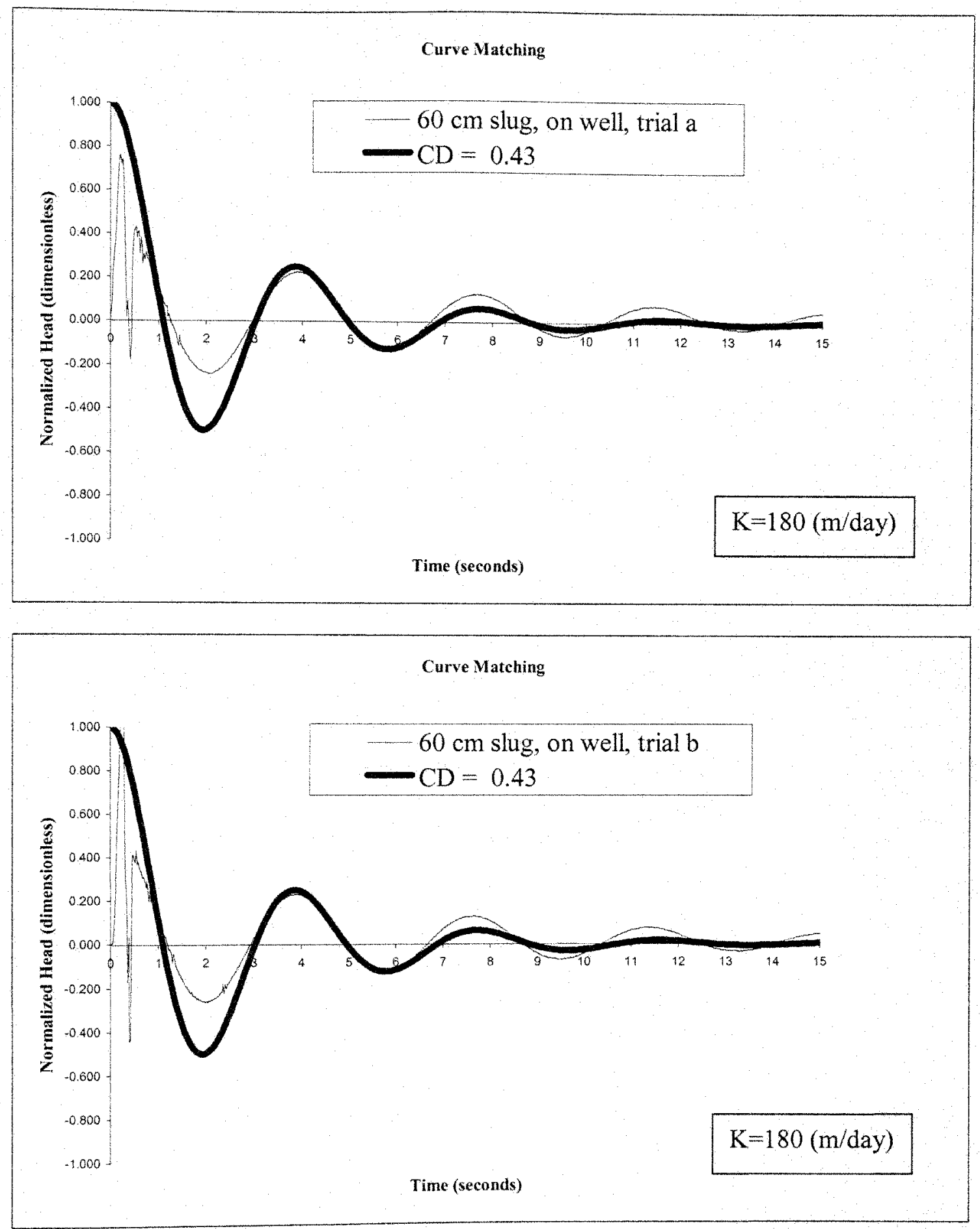

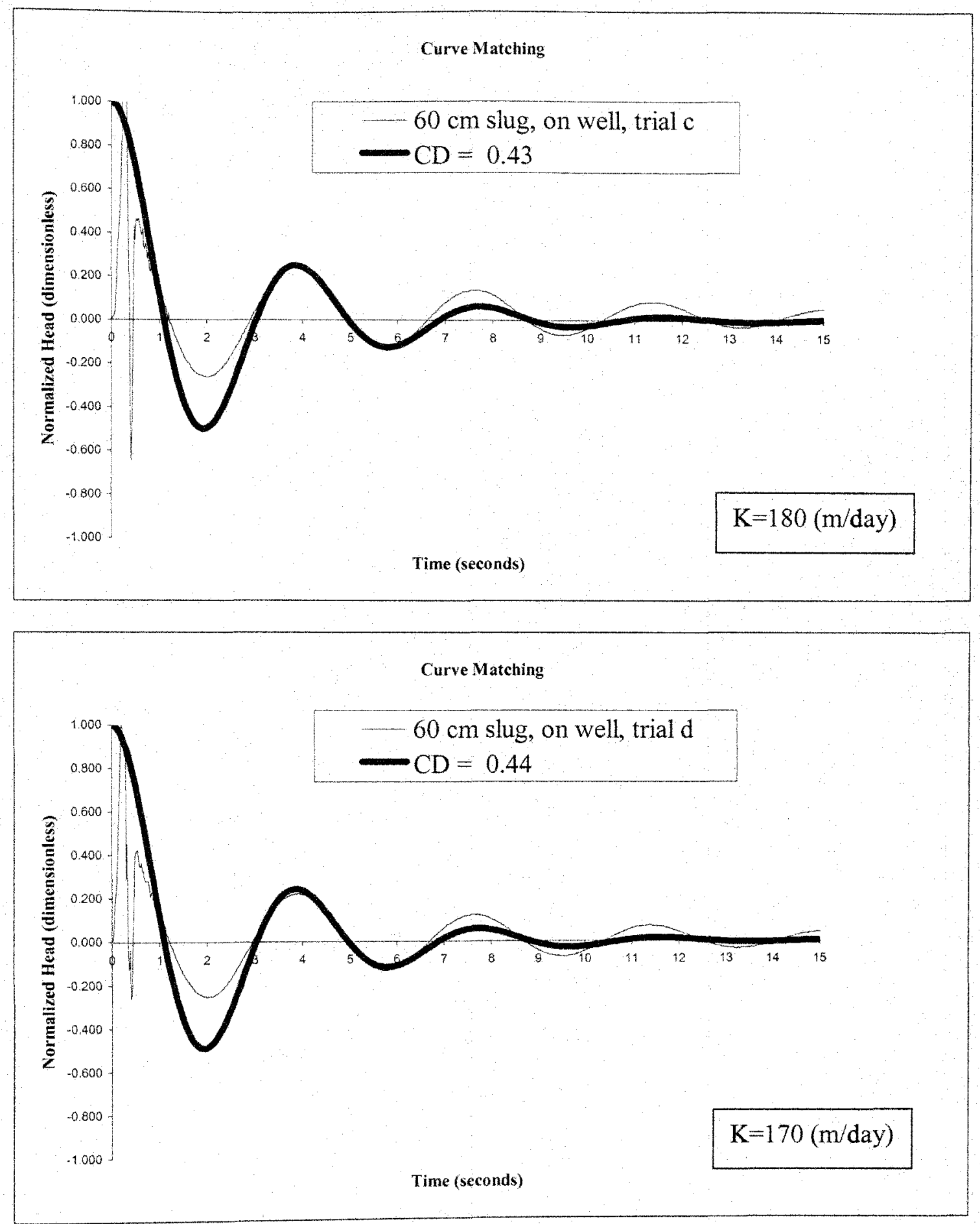

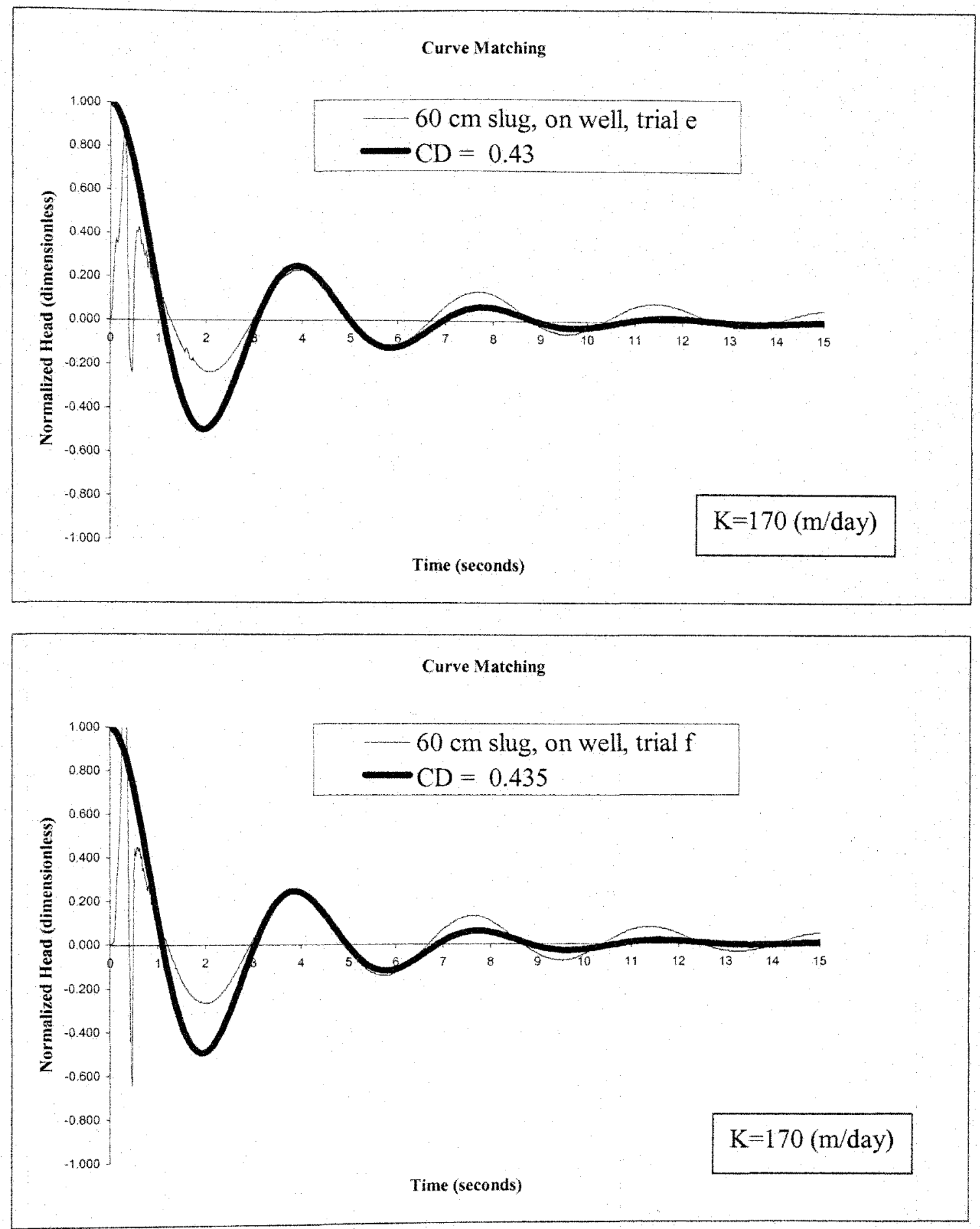


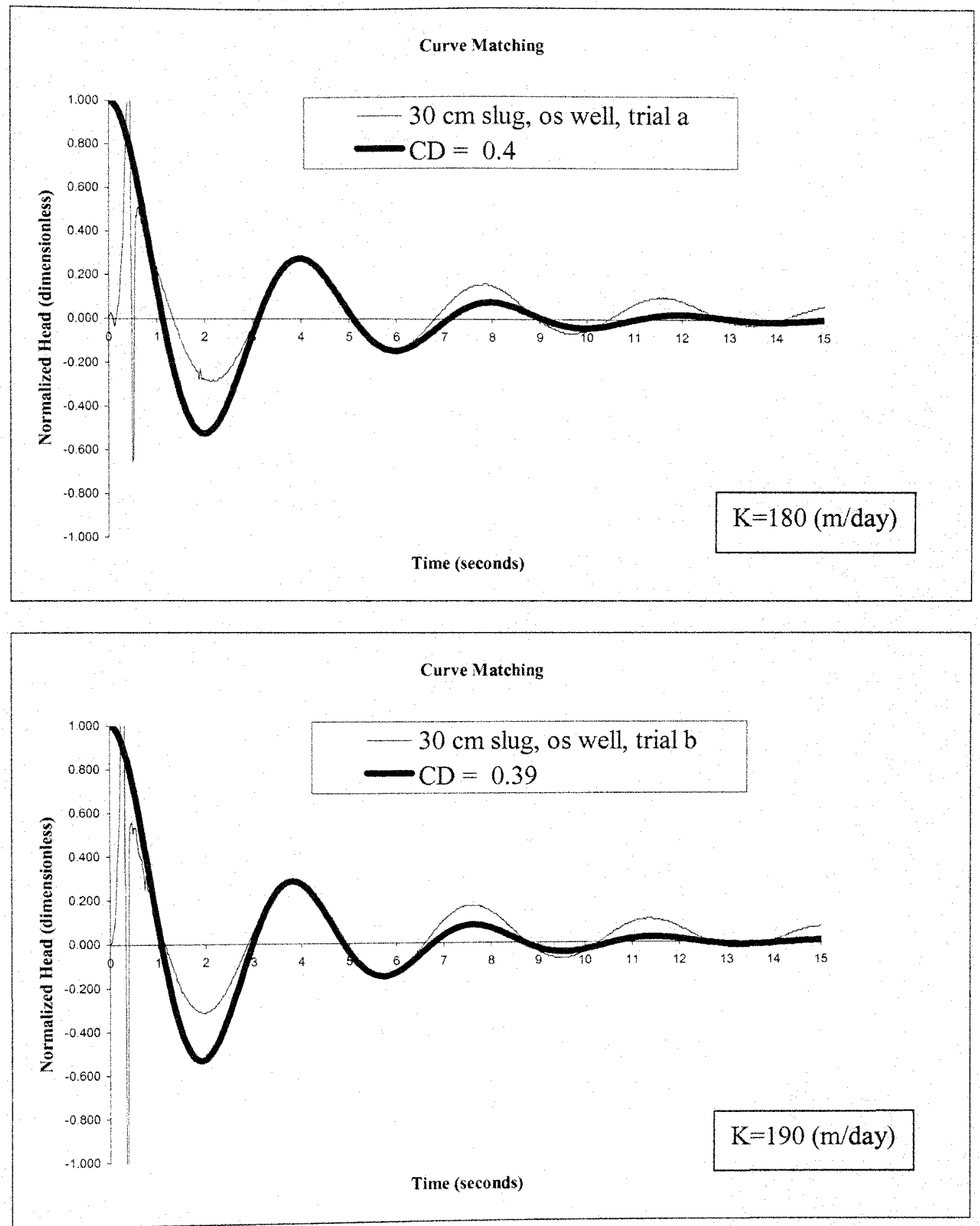



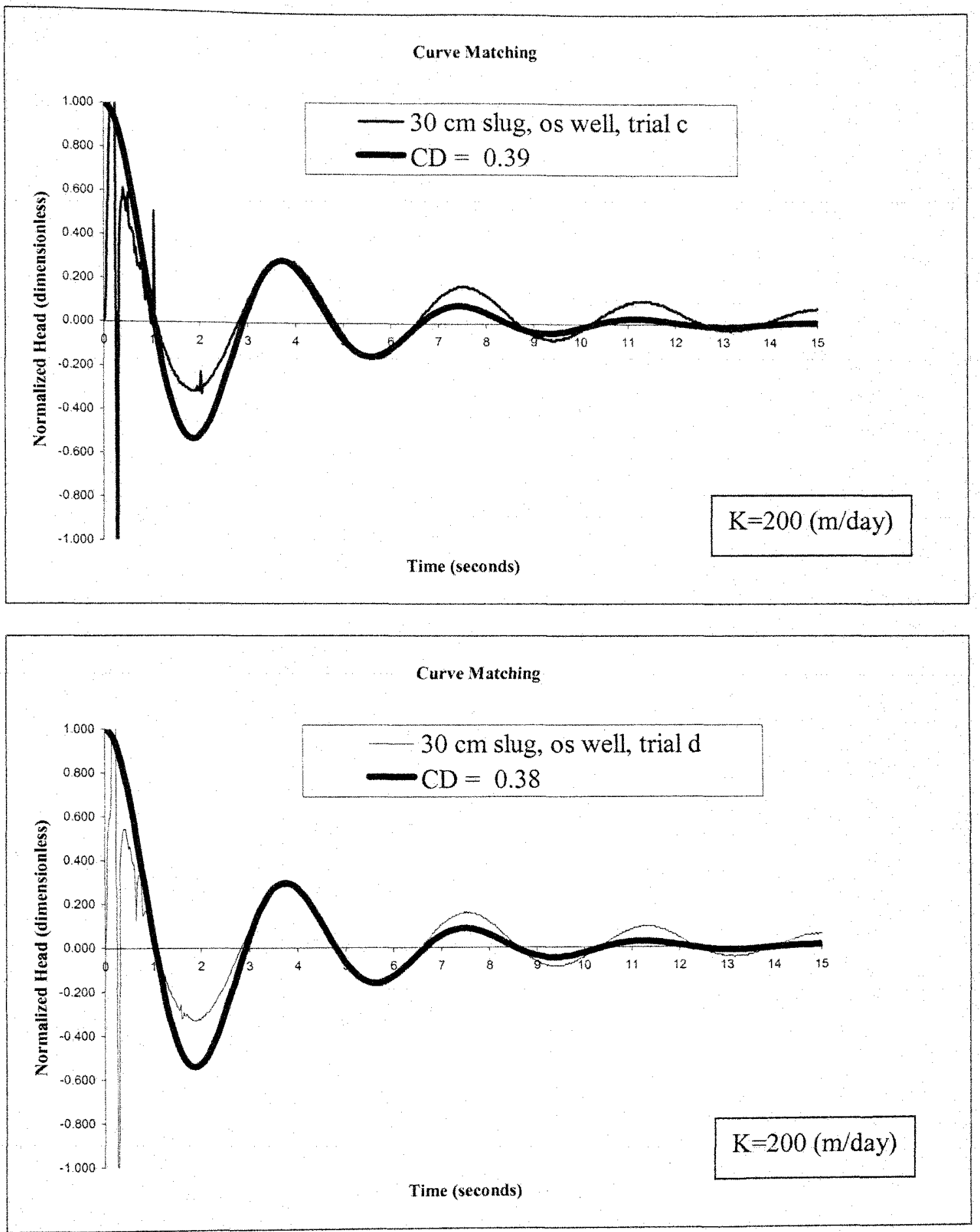

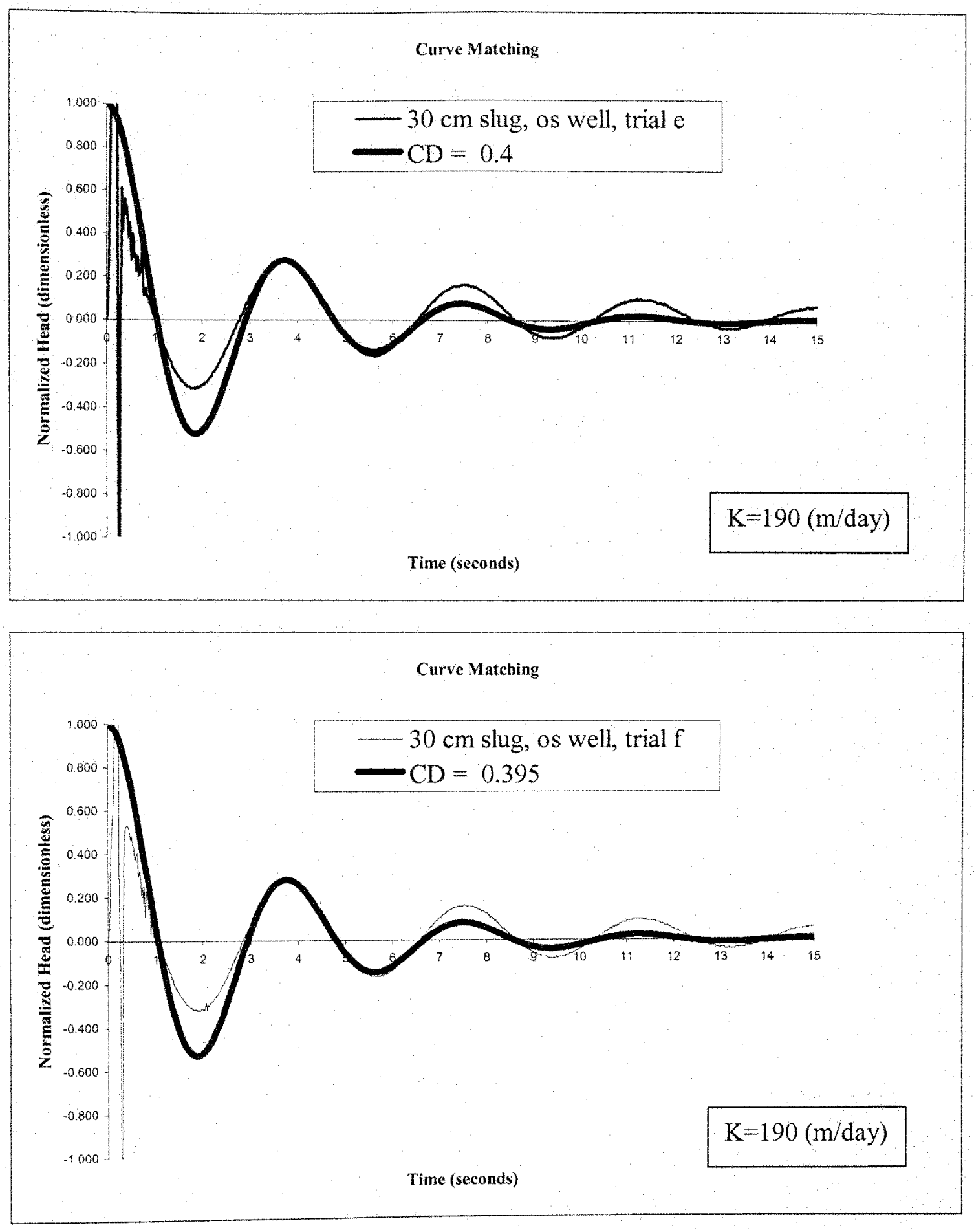

186 

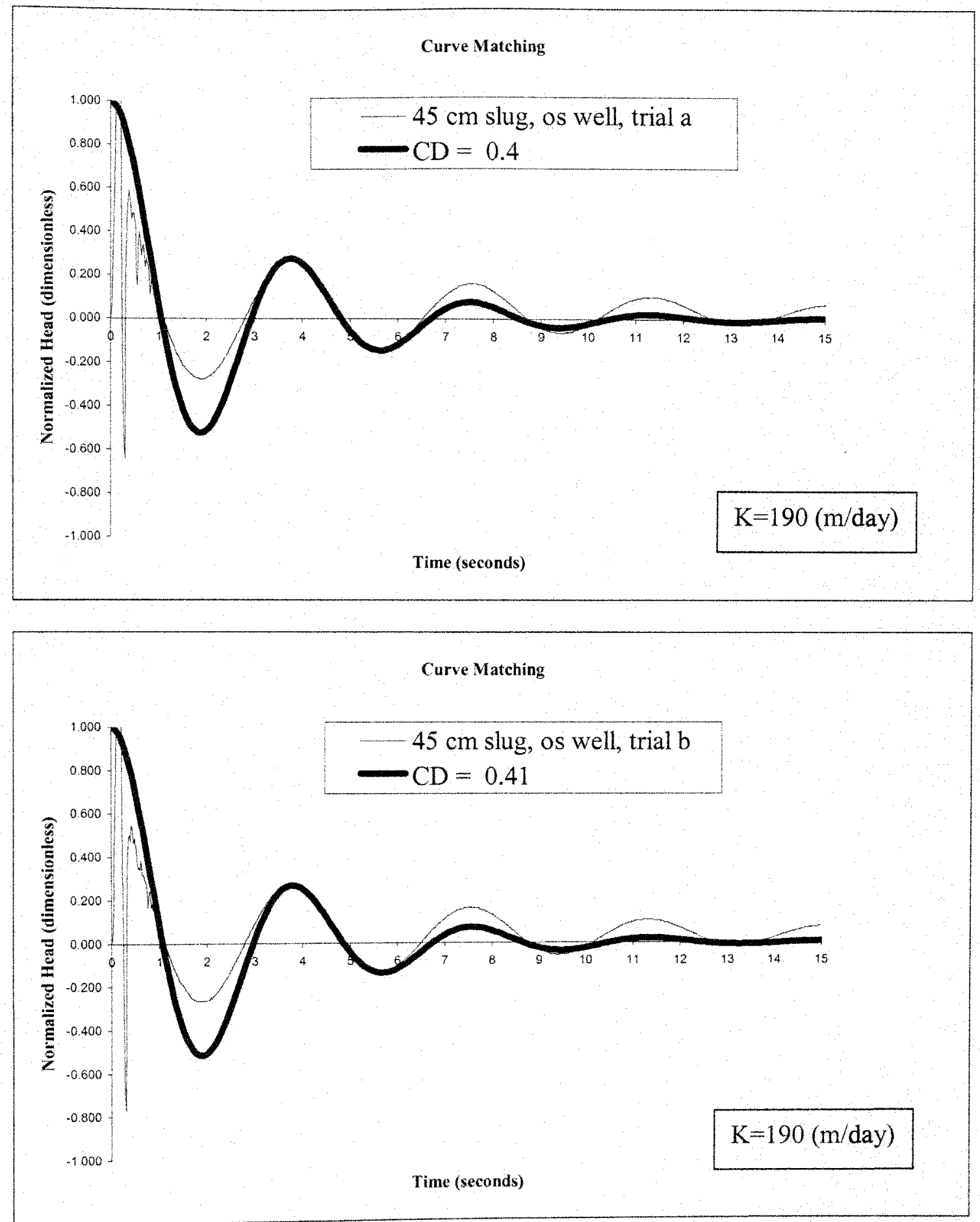

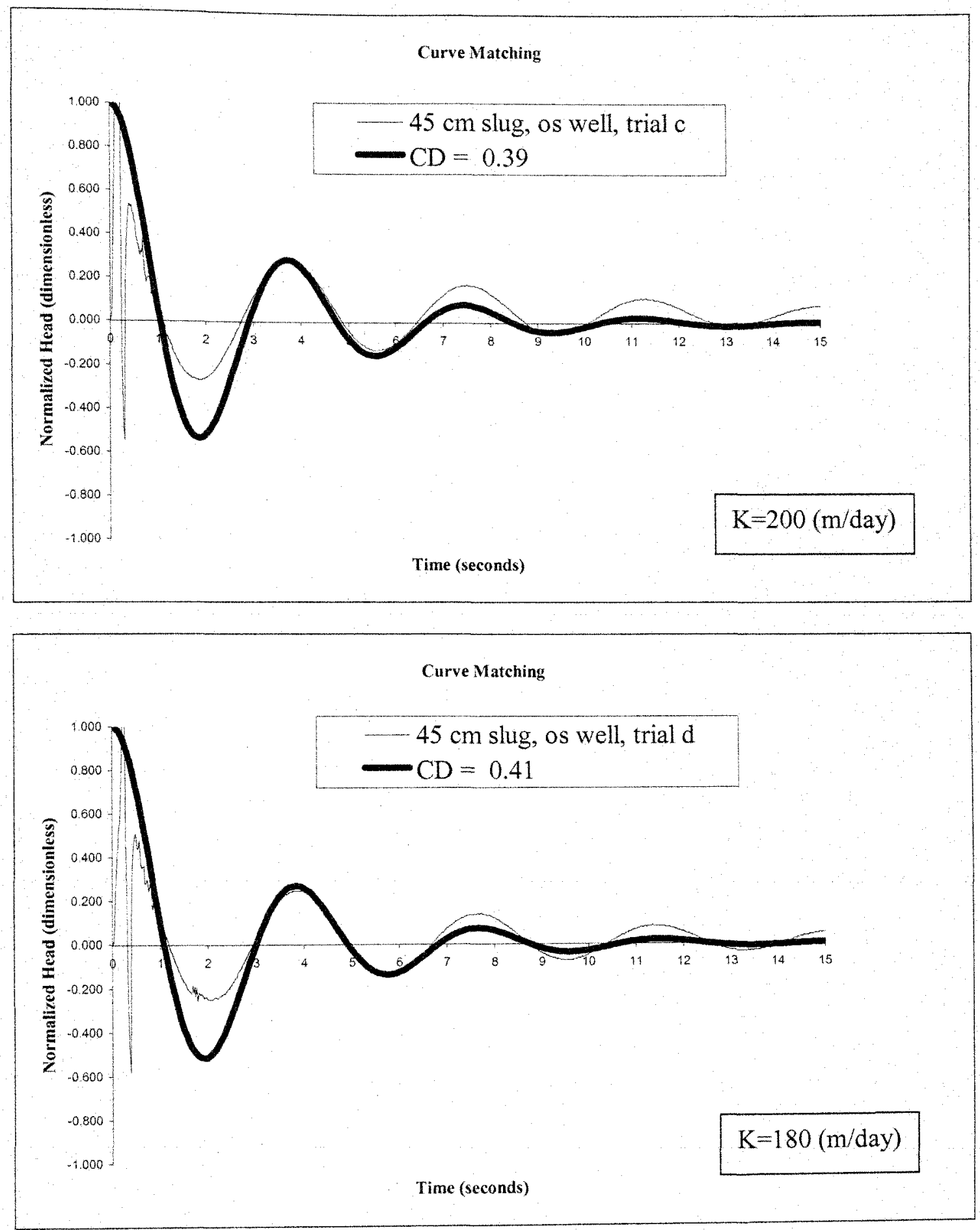
(spuosəs) วu!

$($ (Kер/u) $0 L I=\mathrm{X}$

zt $0=a D$

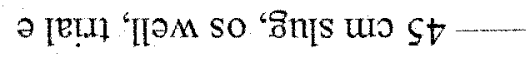

$.000 \%$

$0080^{-}$

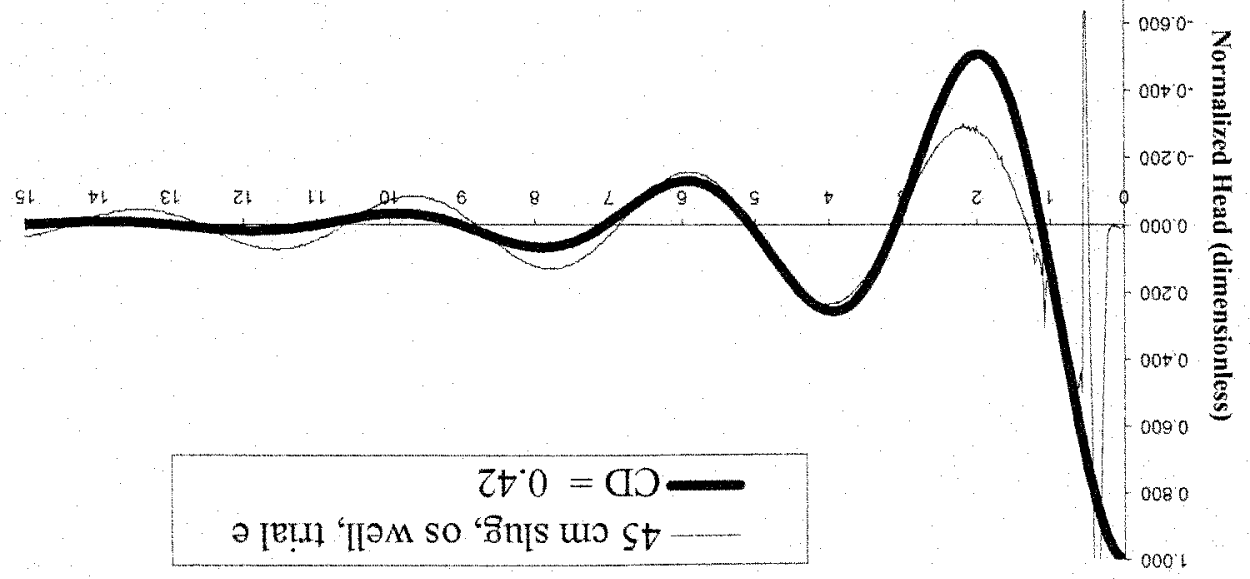

8u!qจeพ a.anว 

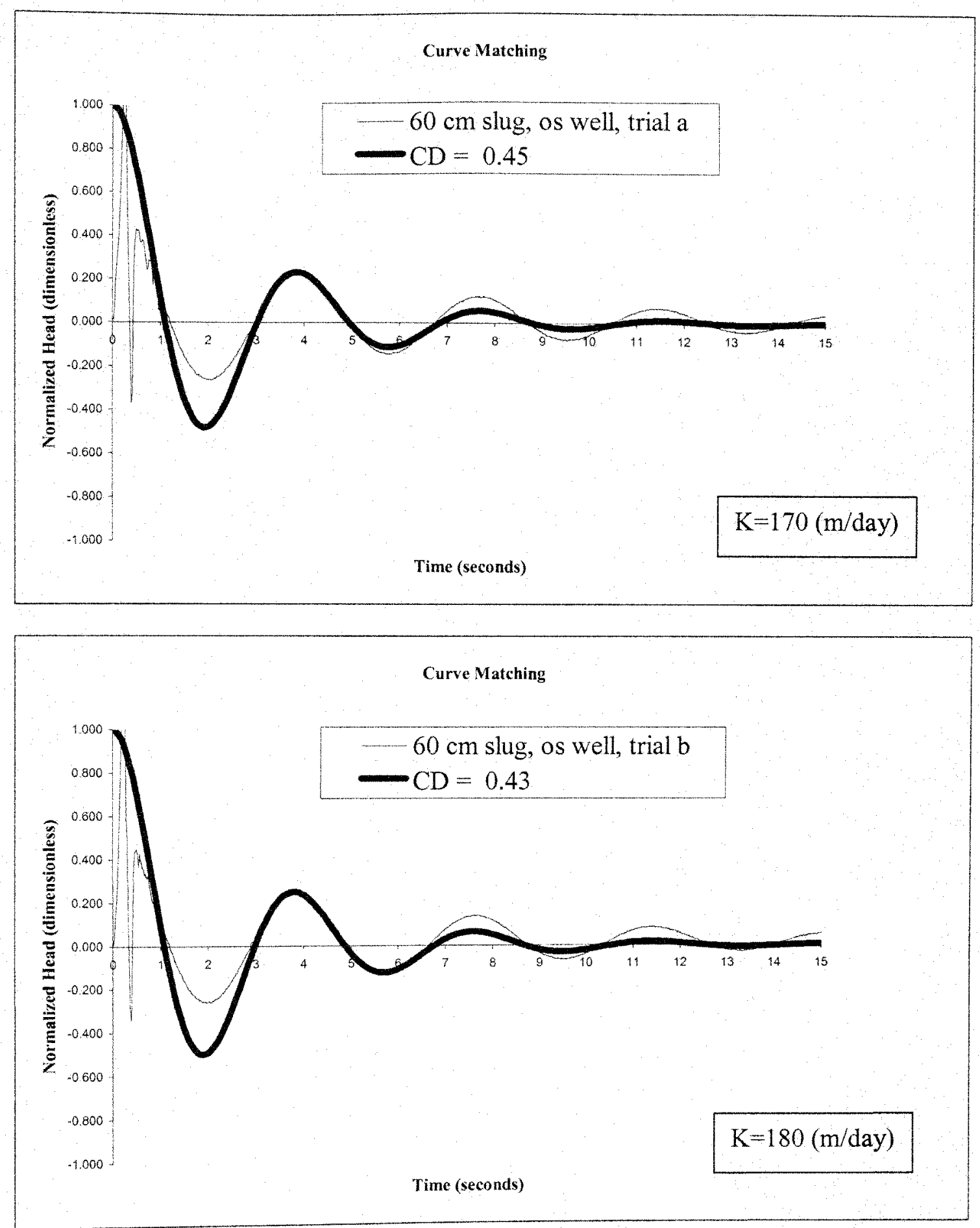


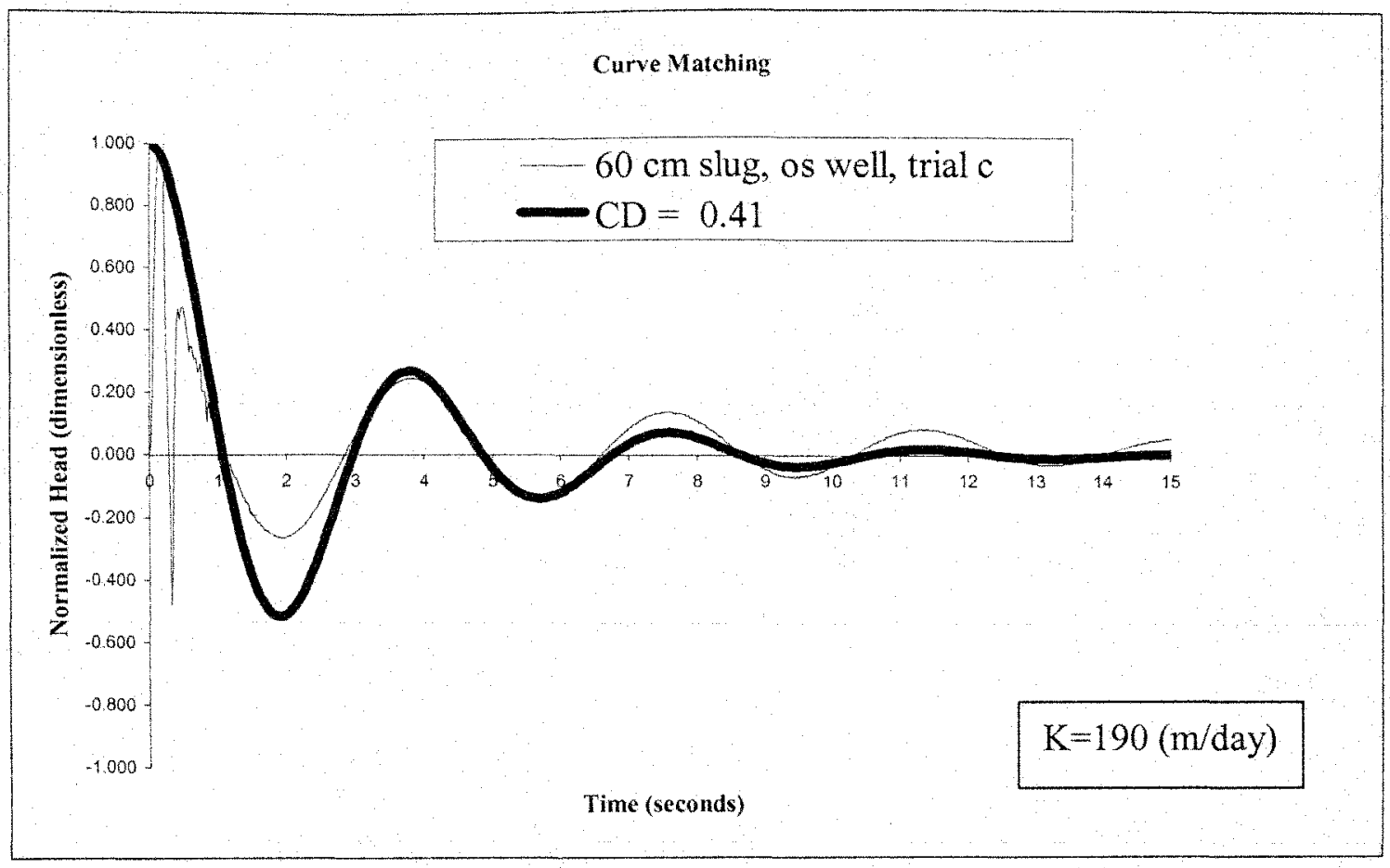

